UNIVERSIDADE DE SÃO PAULO

INSTITUTO OCEANOGRÁFICO

\title{
TAXAS DE SEDIMENTAÇÃO HOLOCÊNICA NA PLATAFORMA CONTINENTAL SUL DO ESTADO DE SÃO PAULO
}

\author{
MOYSÉS GONSALEZ TESSLER
}

Tese apresentada ao Instituto Oceanográfico da Universidade de São Paulo como requisito parcial para a obtenção do título de Livre-Docente junto ao Departamento de Oceanografia Física. 
Índice

1. INTRODUÇÃO

2. OBJETIVOS

3. ÁREA DE ESTUDO

4. CONDICIONANTES GEOLÓGICOS, GEOMORFOLÓGICOS E OCEANOGRÁFICOS DA ÁREA DE ESTUDO

4.1 Sistema Continental. O Complexo Serrano

4.1.1 Geomorfologia e Clima

4.1.2 Geologia Regional

4.1.3 Bacias de drenagem

4.1.4 O Rio Ribeira de Iguape

4.1.4.1 Regime fluvial (vazão)

4.1.4.2 Transporte de sedimentos

4.1.5 Histórico da mineração no Vale do Ribeira

4.1.6 A origem e os níveis de metais pesados na drenagem do Rio Ribeira de Iguape

4.2 Sistema Continental. Planície costeira. Sistema Cananéia-Iguape

4.2.1 Fisiografia do Sistema

4.2.2 Gênese do Sistema

4.2.3 A hidrodinâmica nos canais

4.2.4 Caracterização textural dos sedimentos de fundo dos canais

4.2.5 Caracterização geoquímica dos sedimentos

4.2.6 Taxas de sedimentação

4.3 Sistema Marinho

4.3.1 Origem e evolução tectônica da margem continental sudeste brasileira

4.3.2 Fisiografia e morfologia do fundo (Embaiamento de São Paulo)

4.3.3 Dinâmica das massas d'água na margem continental sudeste/sul do Brasil

4.3.4 Dinâmica das correntes costeiras

4.3.5 Transporte de sedimentos em suspensão

4.3.6 A distribuição dos sedimentos da atual superfície de fundo

5. COLETA E PREPARAÇÃO DOS TESTEMUNHOS

5.1 Descrição geral dos testemunhos

6. CARACTERIZAÇÃO TEXTURAL E COMPOSICIONAL DOS TESTEMUNHOS

6.1 Metodologias de análise 
6.2 Análise dos resultados

6.2.1 Teores de areia e lama

6.2.2 Teores de Carbonato biodetrítico

6.2.3 Teores de carbono orgânico, nitrogênio e enxofre total

6.2.4 Teores totais dos elementos Chumbo, Cobre e Zinco

7. DETERMINAÇÃO DA COMPOSIÇÃO ISOTÓPICA (Pb/Pb)

7.1 Metodologia de análise

7.2 Análise dos resultados

8. TAXAS DE SEDIMENTAÇÃO

8.1 Métodos de estudos para obtenção de taxas de sedimentação em ambientes marinhos rasos

8.2 Metodologia de análise

8.2.1 Datações ${ }^{14} \mathrm{C}$

8.2.2 Determinações do ${ }^{210} \mathrm{~Pb}$

8.3 Análise dos resultados

8.3.1 Datações ${ }^{14} \mathrm{C}$

8.3.2 Espectrometria Gama $\left({ }^{210} \mathrm{~Pb}\right)$

9. DISCUSSÃO DOS RESULTADOS

10. CONSIDERAÇÕES GERAIS

11. REFERÊNCIAS BIBLIOGRÁFICAS 


\section{Localização das Figuras}

Figura 1. Mapa de localização da área de estudos e dos pontos de amostragem.

Figura 2. Mapa geológico do Vale do Ribeira.

Figura 3. Mapa geológico da área da bacia de drenagem do Rio Ribeira de Iguape (Campanha,1991, apud Moraes, 1997).

Figura 4. Mapa de drenagem do sul/sudeste do Estado de São Paulo (Vale do Ribeira), e nordeste do Estado do Paraná.

Figura 5. (a)Descrição dos testemunhos de sondagem dos poços IGC-1 e C-2 (Petri \& Suguio, 1973) e (b) Estratigrafia da planície costeira Cananéia-Iguape (Souza,1995).

Figura 6. Estágios de formação da planície costeira Cananéia-Iguape (Suguio \& Martin,1978).

Figura 7. Evolução da llha Comprida durante o Holoceno. Modificado de Suguio \& Martin (1978).

Figura 8. Propagação das correntes de maré no Sistema Cananéia-Iguape.

Figura 9. Mapa de classificação textural dos sedimentos de fundo do Sistema Cananéia Iguape ( classificação de Shepard,1954, apud Tessler \& Souza, 1998).

Figura 10.Esboço estrutural do sudeste brasileiro ( Almeida, 1986, apud Suguio \& Martin 1978).

Figura 11.(a) Imagem AVHRR da margem continental brasileira, mostrando assinaturas das temperaturas associadas com a corrente do Brasil e (b) Representação esquemática do meandramento da Corrente do Brasil ( Mahiques et.al., no prelo).

Figura 12.Esquema de propagação dos Sistemas Frontais no Atlântico meridional (Rodrigues, 1996).

Figura 13.Correntes de superfície do litoral sul paulista através da interpretação das imagens do satélite LANDSAT - MSS, canais 4 e 5 (26/06/76).

Figura 14.Mapa de fácies sedimentares da plataforma continental localizada entre os estados de São Paulo e Santa Catarina ( Corrêa, 1978).

Figura 15.Mapa sedimentológico da plataforma continental do Estado de São Paulo. Padrão textural dos sedimentos segundo Shepard (1954). I.O.USP (no prelo).

Figura 16.Mapa sedimentológico da plataforma continental do estado de São Paulo. Padrão textural dos sedimentos segundo Larsonneur (1977, apud Dias, 1996). I.O.USP ( no prelo). 
Figura 17.Variações dos parâmetros analisados ao longo dos testemunhos.

Figura 18.Variação espacial dos teores de Carbono orgânico ( $\mathrm{mg} / \mathrm{g})$, na plataforma continental do Estado de São Paulo (Mahiques,1998).

Figura 19.Razão C/N ( perfil 1 - NW/SE)

Figura 20.Mapeamento geoquímico . Plataforma continental sul do Estado de São Paulo (Machado, 1985, CPRM).

Figura 21. (a). Diagrama entre as razões isotópicas do chumbo ( 207/204 x 206/204).

(b). Diagrama entre as razões isotópicas do chumbo ( 208/204 x 206/204).

(c). Diagrama entre as razões isotópicas do chumbo ( $206 / 207 \times 206 / 204)$.

Figura 22.Idades interpoladas ${ }^{14} \mathrm{C}$.Perfil 100 metros.

Figura 23.Idades interpoladas ${ }^{14} \mathrm{C}$. Perfil transversal à costa.

Figura 24.Gráfico ajustado da concentração de ${ }^{210} \mathrm{~Pb}_{\text {(não suportado) }}$ em função da profundidade para o testemunho 6651.

Figura 25.Gráfico ajustado da concentração de ${ }^{210} \mathrm{~Pb}_{\text {(não suportado) }}$ em função da profundidade para o testemunho 6653.

Figura 26.Gráfico ajustado da concentração de ${ }^{210} \mathrm{~Pb}_{\text {(não suportado) }}$ em função da profundidade para o testemunho 6654 .

Figura 27.Gráfico ajustado da concentração de ${ }^{210} \mathrm{~Pb}_{\text {(não suportado) }}$ em função da profundidade para o testemunho 6655 .

Figura 28.Gráfico ajustado da concentração de ${ }^{210} \mathrm{~Pb}_{\text {(não suportado) }}$ em função da profundidade para o testemunho 6658 .

Figura 29.Gráfico ajustado da concentração de ${ }^{210} \mathrm{~Pb}_{\text {(não suportado) }}$ em função da profundidade para o testemunho $6683(0-22 \mathrm{~cm})$.

Figura 30.Gráfico ajustado da concentração de ${ }^{210} \mathrm{~Pb}_{\text {(não suportado) }}$ em função da profundidade para o testemunho $6683(0-28 \mathrm{~cm})$.

Figura 31.Gráfico ajustado da concentração de ${ }^{210} \mathrm{~Pb}_{\text {(não suportado) }}$ em função da profundidade para o testemunho 6692

Figura 32.Gráfico ajustado da concentração de ${ }^{210} \mathrm{~Pb}_{\text {(não suportado) }}$ em função da profundidade para o testemunho 6696.

Figura 33.Gráfico ajustado da concentração de ${ }^{210} \mathrm{~Pb}_{\text {(não suportado) }} \mathrm{em}$ função da profundidade para o testemunho 6700 .

Figura 34.Gráfico ajustado da concentração de ${ }^{210} \mathrm{~Pb}_{\text {(não suportado) }}$ em função da profundidade para o testemunho 6704 


\section{Localização das tabelas}

Tabela 1. Posicionamento das estações de coleta.

Tabela 2. Resultados obtidos das análises executadas.

Tabela 3. Resultados obtidos para as análises da razão isotópica do chumbo.

Tabela 4. Resultados obtidos para as taxas de sedimentação . Idades calibradas ${ }^{14} \mathrm{C}$. Beta Analytics.

Tabela 5. Resultados obtidos para a taxa de sedimentação nos diferentes testemunhos. 


\section{INTRODUÇÃO}

A lacuna de levantamentos sistemáticos de parâmetros hidrodinâmicos tem dificultado o estabelecimento de modelos de circulação litorânea de fundo e de plataforma e, consequentemente, o conhecimento acerca das tendências atuais de movimentação, remobilização e aporte de sedimentos terrígenos e marinhos na plataforma continental sudeste do Brasil.

De acordo com a cartografia sedimentar existente (Corrêa, 1978; REMAC, 1979), a sedimentação na plataforma continental sudeste brasileira é essencialmente terrígena, formada por areias e lamas, de natureza quartzosa. Esta sedimentação é referida como resultante, predominantemente, do retrabalhamento de sedimentos oriundos de eventos regressivos quaternários.

As questões relacionadas à atual contribuição de sedimentos continentais para a plataforma continental sudeste, em especial no litoral sul paulista, não têm sido convenientemente enfocadas, muito embora este trecho da plataforma brasileira apresente uma razoável cobertura em termos de amostras analisadas quase que exclusivamente quanto à granulometria.

A presença de sedimentos pelíticos, ricos em elementos metálicos, nos sistemas costeiros do litoral sul paulista, provenientes das áreas mineralizadas do alto Vale do Ribeira, constitui o testemunho da importância do sistema fluvial como fonte atual de sedimentos terrígenos para áreas marinhas rasas (Tessler et al., 1987; Ferreira, 1994 e Moraes, 1997).

A ausência de áreas expressivas de sedimentação pelítica na plataforma continental interna sul do Estado de São Paulo ressalta a questão do destino da carga de sedimentos em suspensão, rico em constituintes metálicos, exportados pela desembocadura do Rio Ribeira, bem como dos mecanismos de dinâmica costeira que são os responsáveis pela remobilização desse material para regiões mais profundas da plataforma continental.

A retirada de sedimentos em suspensão, de áreas costeiras para regiões oceânicas mais profundas, foram descritas por Mahiques et.al. (1999), para o litoral norte paulista. De acordo com os autores esses processos de deslocamento 
estão intimamente relacionados aos ciclos sazonais de avanço e recuo da Água Costeira (AC) e da Água Central do Atlântico Sul (ACAS). A este padrão geral deve se sobrepor, para o litoral sul paulista a dinâmica costeira condicionada pelos eventos meteorológicos, em especial os relacionados aos avanços dos sistemas frontais.

A identificação da possível contribuição atual de sedimentos terrígenos finos, associados à drenagem do Rio Ribeira de Iguape e/ou às desembocaduras dos sistemas estuarino-lagunares do litoral sul paulista, para áreas da plataforma externa sul do Estado, reveste-se de grande importância, na medida em que as faixas de caráter eminentemente lamoso, que ocupam isóbatas acima de 50 metros são áreas preferenciais de pesca de arrasto no litoral paulista. Inclui-se ainda, o fato de que o reconhecimento das formas e abrangência da dispersão deste material permite inferir quanto à dimensão de possíveis alterações ambientais geradas pela entrada de elementos impactantes, de origem natural ou antrópica, no sistema.

Estudos realizados com a utilização de indicadores geoquímicos, de traçadores radioativos e de taxas de sedimentação baseados em radionuclídeos naturais, em especial o ${ }^{14} \mathrm{C}$ e o ${ }^{210} \mathrm{~Pb}$, têm sido considerados como importantes auxiliares na compreensão da dinâmica de aporte e dispersão de elementos provenientes de diversas fontes para os ambientes marinhos (Smith \& Bewers, 1993; Saito et al. 1997).

Muitos elementos radioativos são reciclados, acumulados e, posteriormente, liberados para os oceanos, existindo uma grande interação entre os ambientes terrestres e os ambientes marinhos. A lixiviação dos continentes, a atividade orgânica do próprio meio marinho, junto com o vulcanismo submarino e o transporte pelos aerossóis atmosféricos são, provavelmente, as principais rotas de aporte dos radionuclídeos para os oceanos.

Análises das idades ${ }^{14} \mathrm{C}$ e das concentrações de ${ }^{210} \mathrm{~Pb}$ em testemunhos marinhos possibilitam recompor o registro paleoambiental, mais particularmente dos eventos ocorridos na plataforma após o Último Máximo Glacial, permitindo aprimorar o conhecimento da dinâmica de circulação atual e, principalmente, 
estimar o "background" e as variações temporais do aporte de sedimentos continentais no Holoceno.

Datações ${ }^{14} \mathrm{C}$, de escala milenar, têm sido o principal instrumento utilizado para cálculo das taxas de sedimentação das seqüências sedimentares holocênicas depositadas nas atuais margens continentais (Arz et.al, $1999 \underline{a}$ e $\underline{b}$; Mahiques, et.al., no prelo). Para a obtenção de taxas de sedimentação de períodos mais recentes, especificamente para os últimos cem anos, têm sido utilizadas técnicas baseadas nas séries de decaimento radioativo de radionuclídeos de meia vida compatível com esta escala de tempo $\left({ }^{210} \mathrm{~Pb},{ }^{137} \mathrm{Cs}\right)$, através de métodos radioquímicos de detecção alfa ou beta (Sommerfield \& Nittrouer, 1999; Fuller, et. al, 1999; Huh et. al, 1999) e, mais recentemente, de técnicas de análise instrumental de espectrometria gama.

Estudos sobre taxa de sedimentação, através da utilização das técnicas de análise instrumental para $\circ{ }^{210} \mathrm{~Pb}$, não suportado, nunca foram efetuados em áreas marinhas da plataforma brasileira. Esse tipo de estudo pode, quando associado a um conjunto de informações geomorfológicas, geológicas e oceanográficas, aprimorar os conhecimentos existentes sobre a dinâmica atual dos processos de aporte e redistribuição dos sedimentos de fundo da plataforma continental, principalmente nos aspectos referentes à contribuição atual das fontes continentais e dos fundos marinhos próximos. 


\section{OBJETIVOS}

É objetivo principal deste trabalho a obtenção das taxas de sedimentação holocênica, dos sedimentos areno-lamosos da plataforma continental sul do Estado de São Paulo, visando aprimorar o conhecimento sobre a dinâmica atual dos processos de aporte sedimentar, a partir de fontes continentais e de fundos marinhos próximos.

Os objetivos específicos deste trabalho, inseridos no contexto de seu objetivo principal são:

- Estimar variações dos níveis de emissão relacionadas ao radionuclídeo ${ }^{210} \mathrm{~Pb}$, ao longo da coluna sedimentar, visando aprimorar o conhecimento sobre as modificações ambientais recentes, vinculadas às alterações na dinâmica marinha e às tendências de variação do nível relativo do mar e,

- Verificar as variações espaço-temporais, relativas aos elementos metálicos ( $\mathrm{Pb}, \mathrm{Zn}$ e $\mathrm{Cu}$ ), ao longo da coluna sedimentar, objetivando identificar oscilações recentes do aporte continental, relacionadas ao conhecimento de que a fonte atual de sedimentos, com elevados teores desses elementos, está associada às rochas mineralizadas do Alto Vale do Ribeira. 


\section{3. ÁREA DE ESTUDO}

A área de estudo compreende a plataforma continental sul do Estado de São Paulo entre as latitudes $24^{\circ} 30^{\prime} \mathrm{S}$ (Peruíbe, SP) e $26^{\circ} 00^{\prime} \mathrm{S}$ (proximidades da baía de Paranaguá, $\mathrm{Pr}$ ), e as longitudes $45^{\circ} 00^{\prime} \mathrm{W}$ e $48^{\circ} 00^{\prime} \mathrm{W}$. A área estende-se desde a isóbata de 50 metros, limite aproximado entre as áreas de predomínio de sedimentos arenosos e pelíticos, até a quebra da plataforma ( 200 metros).

A Figura 1 apresenta a localização da área de estudo e a distribuição amostral utilizada para a execução deste estudo. 


\section{CONDICIONANTES GEOLÓGICOS, GEOMORFOLÓGICOS E OCEANOGRÁFICOS DA ÁREA DE ESTUDO}

A margem continental sul paulista está inserida no Embaiamento de São Paulo, definido por Butler (1970). Esta unidade fisiográfica é margeada, em sua borda continental, por extensas planícies costeiras quaternárias limitadas, em sua porção interior, pelo Complexo da Serra do Mar, e pela principal feição geomorfológica estabelecida no limite político entre os estados de São Paulo e Paraná, denominada genericamente de Vale do Ribeira, potenciais fontes atuais dos sedimentos que recobririam a margem continental sul paulista.

O Vale do Ribeira abriga a principal bacia de drenagem da porção oriental do Estado de São Paulo, a do Rio Ribeira de Iguape. O Vale do Ribeira representa uma importante província mineral, sustentada por um potencial de exploração para chumbo, zinco, prata e ouro, além de outros minerais não metálicos (Silva, 1997).

\subsection{Sistema Continental. O Complexo Serrano.}

\subsubsection{Geomorfologia e Clima}

As características geomorfológicas gerais do Vale do Ribeira levaram Almeida (1964) a enquadrá-lo como pertencente à Província Costeira, apresentando um relevo acidentado com amplos desníveis. O mapeamento geológico sistemático, realizado pela Companhia de Pesquisa de Recursos Minerais (CPRM, 1978), caracteriza a geologia da área como muito diversificada, com suas estruturas influenciando decisivamente a configuração das formas topográficas de relevo, sendo que as maiores elevações são sustentadas principalmente por quartzitos (Grupo Açunguí), por vezes por rochas graníticas e muito raramente por rochas carbonáticas silicatadas (Figura 2).

No Alto Vale do Ribeira e em parte do Médio Vale, a combinação de um relevo muito complexo, aliado a grande diversidade lito-estrutural, faz com que haja encostas com amplitudes locais de 100 a 300 metros (morros isolados) e acima de 300 metros (serrania costeira) e declividades acima de 15\%. Existem, porém, altos topográficos de até 1300 metros acima do nível do mar. 
$\mathrm{Na}$ região do Médio Vale, nas proximidades da foz do Rio Juquiá, desenvolve-se uma área de relevo suave, interrompida pela presença de maciços rochosos e morros isolados, cujas declividades não ultrapassam 15\%, e com amplitudes locais máximas de 100 metros.

A faixa litorânea está situada pouco acima do nível do mar atual, com altitudes não superiores a uma dezena de metros. A topografia é marcada por planícies de cordões litorâneos, vegetação de restinga, e manguezais, que se desenvolvem ao longo dos extensos corpos de água salobra.

O clima, de acordo com a classificação de Koppen, apresenta-se com características de tropical úmido, variando entre tropical úmido sem estação seca e tropical úmido com verão fresco.

A pluviosidade é característica de regiões subtropicais, com precipitação média entre 2200 e $2300 \mathrm{~mm} / \mathrm{ano}$, sendo o predomínio dos períodos chuvosos entre os meses de novembro e fevereiro. A temperatura média anual está entre $16^{\circ}$ e $19^{\circ} \mathrm{C}$, sendo que valores extremos de até $35^{\circ} \mathrm{C}$ podem ser observados nos meses de verão e de $0^{\circ} \mathrm{C}$ nos meses de inverno (JICA,1984).

\subsubsection{Geologia Regional}

Segundo Campanha (1991), a região do Vale do Ribeira, está inserida no domínio de duas grandes unidades geotectônicas, quais sejam: a faixa de dobramentos Apiaí, que contém a quase totalidade das ocorrências de minério de chumbo e o Maciço de Joinville.

Nos levantamentos e mapeamentos realizados por Chiodi (1984) e Campanha (1991), a faixa de dobramento Apiaí apresenta estruturação NE/SW, de faixas alternadas, predominantemente, de rochas metamórficas supracrustais, de baixo grau e, secundariamente, de médio grau, intrudidas por grande número de corpos granitóides, formando um complexo mosaico de blocos litológicos afetados por um denso sistema de cisalhamento anastomosado (Moraes, 1997).

Campanha et al. (1987) indicam que a faixa de dobramentos Apiaí se enquadra num modelo de subducção de placa oceânica de sudeste para noroeste, com uma posterior colisão continental. As formações Itaiacoca e Capiru 
representariam os marcadores das antigas margens continentais, sobrepostas no "Cráton" do Paraná, o granito Três Córregos caracterizaria o arco magmático e a região delineada pelas formações Iporanga e Perau definiriam a zona de sutura da subducção (Kaul, 1984, apud Silva, 1997).

Ebert et al. (1988, apud Silva, 1997) entende que a evolução tectônica da região comportou três processos deformacionais principais, dentro de uma mesma fase progressiva.

Segundo Hasui (1986), sobre o Complexo Costeiro, definido pelo magmatismo granitóide, desenvolveram-se os Grupos Setuva e Açunguí, através de uma subseqüente distensão continental e rifteamento crustal em zonas de tensão.

Para Chiodi (1984), a bacia Setuva surgiu a partir de um suposto aulacógeno enquanto que, no Neoproterozóico, a bacia Açunguí estaria associada à evolução de um "rift" para sinéclise.

Soares (1987, apud Silva, 1997), propõe que o Grupo Setuva teria se originado em bacia de retroarco-ativa, com a deformação dos seus sedimentos ocorrida numa colisão arco-continente e, por sua vez, no processo de rifteamento, a bacia do Açunguí desenvolveu-se atrás do arco magmático onde foram formadas as mineralizações sinsedimentares dos metais.

Já durante o Ciclo Brasiliano, o desenvolvimento das rochas supracrustais foi marcado por um magmatismo toleítico de fundo oceânico (Kaul, 1984 e1985, apud Silva, 1997). Posteriormente, uma deposição de sedimentos imaturos teria sido depositada ao final deste ciclo, concomitantemente à ocorrência de um vulcanismo ácido-intermediário e de intrusões granitóides.

A cratonização, acompanhada dos processos de deposição dos sedimentos da Bacia do Paraná, ocorreu ao longo do Ordoviciano / Siluriano, estabelecendo o atual quadro de evolução da faixa de dobramentos Apiaí no Vale do Ribeira.

De acordo com Daitx (1996), o quadro estratigráfico do Vale do Ribeira pode ser definido, de forma simplificada, por quatro grandes unidades précambrianas: 
- Complexo Cristalino ou Costeiro, que reúne rochas metamórficas, de fácies granulítica (Complexo Granulito Serra Negra);

- Seqüências vulcanosedimentares, de baixo a médio grau de metamorfismo, representadas pelas unidades Setuva, Água Clara, Turvo-Cajatí, Perau e Abapã;

- Seqüências sedimentares metamorfizadas em grau fraco, representadas pelas unidades Iporanga, Itaiacoca, Votuverava, Antinha e Lageado ou, de um modo resumido pelo Grupo Açungui (s.s.) e;

- Complexos Granitóides gnaissificados e corpos graníticos intrusivos de composição cálcio-alcalina e sub-alcalina, em sua maioria.

O mapeamento executado por Campanha (1991) apresenta a estratigrafia da região, subdividida em três grandes grupos: Complexo Gnaíssico Migmatítico; Grupo Setuva e Grupo Açunguí, com a ocorrência de corpos intrusivos. Estes complexos de rochas são sobrepostos por coberturas sedimentares de idades paleozóicas (Bacia do Paraná) e Cenozóicas (Figura 3).

A unidade do Complexo Cristalino ou Costeiro encontra-se distribuída ao longo da região costeira do Estado de São Paulo, sendo limitada, ao norte, pelas rochas do Grupo Açunguí, através da Falha de Cubatão e, no extremo leste paulista, pelo alinhamento Além - Paraíba.

O Complexo Costeiro é uma unidade bastante heterogênea apresentando rochas que sofreram metamorfismo de fácies granulito e anfibolito, bem como migmatização e granitização em graus variados.

Dentre as litologias, predominam as rochas migmatíticas, que incluem metatexitos de estruturas variadas, predominando a estromatítica, diatexistos com termos oftalmíticos e facoidais portando paleossoma de natureza diversa (xistoso,anfibolítico, gnaíssico, quartzítico, calcossilicatico).

Cronologicamente tem sido obtida, na sua maioria, idade Brasiliana para as rochas deste complexo nos estados de São Paulo e Paraná.

O Grupo Setuva é constituído por rochas vulcanosedimentares, de baixo grau de metamorfismo, geralmente posicionadas ao redor de núcleos gnáissicogranitóides, com idades mínimas relativas ao Mesoproterozóico. Sob a 
designação de Grupo Setuva estão representadas todas as rochas das Formações Perau, Setuva e Capiru (Campanha, 1991).

A Formação Perau é constituída, predominantemente, por quartzitos, rochas carbonáticas impuras e quartzo-micaxistos com intercalações subordinadas de anfibolitos, aos quais se associam os depósitos sulfetados representados pelas jazidas do Perau e Canoas.

A Formação Setuva engloba todas as seqüências metassedimentares aflorantes no Anticlinal do Setuva, subjacente a Formação Capiru.

A Formação Capiru é uma seqüência de micaxistos, xistos aluminosos, paragnaisses, quartzo xistos e mármores além de intercalações de quartzitos, carbonatos xistos e filitos. Correspondem a uma seqüência plataformal de águas rasas, com alternância de pacotes carbonáticos, psamíticos e pelíticos (Petri \& Suguio, 1969, apud Moraes, 1997).

O Grupo Açunguí, designação proposta por Marini et al. (1967, apud Chiodi,1984), foi subdividido por Chiodi (op.cit.) nas formações Votuverava (Subgrupos Lageado, de Hasui et al., 1984 apud Chiodi, 1984), Iporanga e Itaiacoca, todas do Proterozóico Superior, considerando-o essencialmente de natureza sedimentar, onde predominam os metacalcários calcíticos e dolomíticos, metarenitos e metasiltitos, posicionados acima do grupo Setuva.

O subgrupo Lageado é constituído por alternância de pacotes relativamente espessos de composição carbonática e psamopelítica. A Formação Iporanga apresenta a ocorrência de níveis e lentes de metabrechas e metaconglomerados polimíticos, com clastos de diversos tamanhos e litologias, matriz lamítica em meio a metapelitos rítmicos predominantes.

A Formação Itaiacoca caracteriza-se pela presença de espessos pacotes de rochas carbonáticas, psamíticas e pelíticas, metamorfizadas em grau baixo. 


\subsubsection{Bacias de Drenagem}

A partir das folhas Curitiba e Iguape (IBGE, 1983), na escala 1:250.000 foi elaborado um mapa de drenagem tendo como limites políticos os municípios de

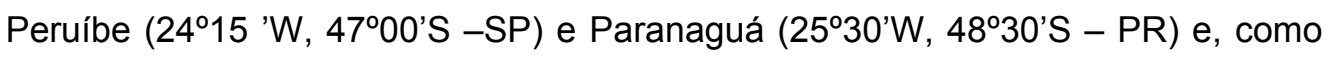
limite continental, o divisor de águas da Serra do Mar (Figura 4).

A drenagem mais desenvolvida é a bacia hidrográfica do Rio Ribeira de Iguape (área A), que ocupa uma área aproximada de $25.000 \mathrm{~km}^{2}$, sendo $61 \%$ contidos nos limites do Estado de São Paulo cortando áreas de 17 municípios, que perfazem $17.000 \mathrm{~km}^{2}$ correspondentes a $6,9 \%$ do território paulista (DAEE, 1984, apud Tessler, 1988), e os 39\% restantes no Estado do Paraná.

A porção mais a norte/nordeste da área é drenada pela bacia do Rio Juquiá, principal afluente do Rio Ribeira de Iguape, abrangendo uma área de aproximadamente $5.000 \mathrm{~km}^{2}$ (área B). Ao longo dos seus quase $200 \mathrm{~km}$ de extensão, o Rio Juquiá drena relevos com elevada declividade média.

A bacia de drenagem do Rio Juquiá vai se juntar à bacia do Rio Ribeira de Iguape a jusante da cidade de Sete Barras, compondo uma drenagem conhecida como bacia hidrográfica do Alto e Médio Ribeira, que drena toda a região entre a Serra do Mar e a planície costeira, esculpindo as rochas do Complexo Cristalino ou Costeiro e do Grupo Açunguí (Figura 3).

Compreendida entre Peruíbe e o Maciço da Juréia encontra-se uma rede de drenagem fortemente influenciada pela ação dos agentes hidrodinâmicos marinhos (área C). Esses cursos d'água têm suas nascentes, predominantemente, localizadas no sistema serrano da Serra do Itatins, com um gradiente elevado em seu trecho inicial e um desenvolvimento suave e meandrante ao longo da planície costeira. Portanto, sua área de influência é restrita ao amplo anfiteatro de sedimentação compreendido entre os pontões cristalinos da Juréia e de Peruíbe.

A sul/sudoeste da área desenvolve-se uma drenagem que converge para as baías de Antonina e Paranaguá (área $\mathrm{D}$ ), com influência nos limites geográficos do Estado de São Paulo apenas na região costeira localizada a oeste do Sistema Cananéia - Iguape, drenando quase que exclusivamente rochas do Complexo Cristalino. 


\subsubsection{O Rio Ribeira de Iguape}

O Rio Ribeira de Iguape tem sua nascente localizada na vertente leste da Serra de Paranapiacaba, em altitudes superiores a 1000 metros, a partir da junção dos rios Ribeirinha e Açunguí, nas proximidades da cidade de Cerro Azul, no Estado do Paraná. Após um percurso de cerca de $470 \mathrm{~km}$ vai desaguar no Oceano Atlântico, na localidade denominada Barra do Ribeira, nas proximidades da cidade de Iguape, no Estado de São Paulo.

Sant'Anna Neto (1990. In. Moraes,1997) caracteriza fisiograficamente a bacia do Rio Ribeira de Iguape como uma feição semelhante a uma "grande ferradura", emoldurada pela serras do Taquari ao sul, do Itatins ao nordeste e Paranapiacaba e/ou do Mar ao noroeste, oeste e sudoeste distantes até $20 \mathrm{~km}$ da atual linha de costa.

De acordo com Moraes (1997), o Rio Ribeira cursa seu trecho inicial em vale profundamente entalhado e encachoeirado, com comportamento torrencial imposto pelas características geomorfológicas e climáticas atuantes na região.

Após a cidade de Itaoca, no Estado de São Paulo, o Ribeira de Iguape desenvolve um padrão meandrante até a jusante da cidade de Eldorado (SP), onde passa a apresentar, em suas faces côncavas, a deposição de sedimentos em forma de barras de ponta.

Desde suas cabeceiras até a região da cidade de Sete Barras, após a junção com o Rio Juquiá, o Ribeira de Iguape drena litologias do Grupo Açunguí, associadas aos alinhamentos Ribeira e Cubatão (Silva,1997). A partir desta região, o Ribeira segue perpendicularmente à linha de costa atual, através de uma estreita faixa de rochas pertencentes ao Complexo Costeiro adentrando a planície costeira que lhe impõe comportamento meândrico (Bistrichi et al.,1981).

A abertura de um canal artificial, interligando o Rio Ribeira de Iguape com o Sistema Cananéia-Iguape (Valo Grande) foi iniciada em 1828 e finalizada em 1852. A abertura deste canal tinha como objetivo interligar um meandro do rio, denominado de Porto do Ribeira, por corresponder à área de desembarque dos produtos agrícolas provenientes do Médio e Baixo Ribeira, à cidade de Iguape onde se localizava o porto de exportação da região. 
O porto de Iguape era localizado no interior do sistema costeiro (Mar Pequeno), passando a ser influenciado, após a abertura do Valo Grande, pela descarga fluvial do Rio Ribeira de Iguape, ao qual se associa um processo de assoreamento acelerado, não apenas dos sedimentos em suspensão, carreados pelo rio, mas também de sedimentos arenosos carreados por tração, a partir da pronunciada erosão das margens do Valo. O canal artificial, com não mais do que $4 \mathrm{~km}$ de extensão, escavado a profundidades inferiores a 2 metros e largura de cerca de 4,4 metros, foi rapidamente erodido pelo curso fluvial. Segundo Geobrás (1966), passado pouco mais de um século da abertura, o Valo Grande já havia atingido cerca de 235 metros de largura e 7 metros de profundidade. Neste período, o Porto de Iguape já havia sido abandonado como pólo exportador da região devido, não apenas ao assoreamento da área do canal do Mar Pequeno, junto ao porto, mas também pela progressiva perda de importância das atividades econômicas da região no contexto do Estado de São Paulo.

Em agosto de 1978, o canal, já com cerca de 250 metros de largura e 7 metros de profundidade, foi fechado pela construção de uma barragem. Entre 1978 e 1983 o Rio Ribeira de Iguape tornou a direcionar todo seu fluxo através do seu leito original. Após 1983, com o rompimento da barragem de terra e pedra, que fechava a intercomunicação do sistema fluvial com o sistema costeiro, as águas do Rio Ribeira voltaram a se dividir entre o Valo Grande e seu canal original. De acordo com o Engenheiro Odair José de Souza (CTH/USP), no início dos anos 90 cerca de $60 \%$ do fluxo fluvial era direcionado para o Valo Grande e, conseqüentemente, para o sistema lagunar.

\subsubsection{Regime fluvial (Vazão)}

O Rio Ribeira de Iguape é considerado um sistema fluvial de regime subtropical, com cheias pronunciadas no verão e estiagem no inverno. Seu regime fluvial acompanha de perto o regime pluvial, sendo observado o aumento da contribuição unitária com o aumento da área contribuinte (Geobrás, 1966).

A partir de dados linimétricos coletados ao longo das bacias dos rios Ribeira de Iguape e Juquiá, no período compreendido entre 1940 e 1965, o relatório 
Geobrás (1966) calculou, para o rio Ribeira uma vazão média anual de $455 \mathrm{~m}^{3} / \mathrm{s}$, para uma bacia considerada de $11.800 \mathrm{~km}^{2}$. As médias mensais calculadas para 0 Rio Ribeira de Iguape, na cidade de Sete Barras, indicaram valores acima de 500 $\mathrm{m}^{3} / \mathrm{s}$ no verão, com médias máximas para o mês de fevereiro que atingiram valores de $700 \mathrm{~m}^{3} / \mathrm{s}$, e mínima no mês de agosto (inverno) com média inferior a $350 \mathrm{~m}^{3} / \mathrm{s}$.

A partir do monitoramento diário de vazão fluvial no período de 1961 a 1970, em três estações de monitoramento fluviométrico do DAEE/CTH (Itaoca, Sete Barras e Registro), a CETESB (1991) calculou, para cada estação de medição, valores médios mensais similares, em ordem de grandeza, aos calculados pela Geobrás (1966) para o período de 1940 a 1965 (CETESB,1991 apud Moraes, 1997).

Considerando-se as características geomorfológicas de cada segmento do canal fluvial compreendido entre as estações de medição, a área drenada e os regimes pluviométricos anuais, as informações obtidas evidenciam a ocorrência de uma significativa diferenciação entre as vazões máximas e mínimas existentes ao longo de todo o percurso fluvial, bem como a sazonalidade deste regime.

\subsubsection{Transporte de sedimentos}

A partir de uma análise expedita da distribuição e caracterização dos sedimentos da calha do Rio Ribeira de Iguape, associado às características do regime fluvial de segmentos da drenagem do rio, o relatório Geobrás (1966) concluiu que o Rio Ribeira de Iguape, ao adentrar na planície costeira, altera significativamente sua capacidade de transporte de sedimentos. As características de rio meandrante resultam na perda de capacidade de transporte de sedimentos por tração. A carga arenosa de fundo da calha do rio é, então, direcionada para as áreas marginais dos meandros do canal fluvial, apenas sendo remobilizada em períodos de alta pluviosidade com o correspondente aumento da velocidade do fluxo fluvial.

Esta perda de capacidade de transporte de sedimentos por tração não encontra correspondência com a carga de suspensão do fluxo fluvial, evidenciada 
pela presença dos depósitos lamosos, atuais e pretéritos, do Baixo Rio Ribeira de Iguape (turfeiras, manguezais, ilhas fluviais) até as proximidades da desembocadura fluvial.

São apenas puntuais as informações sobre concentrações de material em suspensão nas proximidades da foz do rio, bem como do volume exportado para o oceano pelo Rio Ribeira de Iguape. Apenas observações de imagens de sensoriamento remoto (fotografias aéreas, imagens de satélite) que exibem plumas de sedimentos em suspensão, na área da desembocadura fluvial, comprovam a existência do evento. As concentrações das plumas exportadas e seu regime de ocorrência, são apenas estimativas apresentadas a partir do monitoramento dos sólidos em suspensão, executado a partir de 1983 (CETESB, 1984 - 1995), nas estações fluviométricas de Itaoca e Registro (CETESB, 1995 apud Moraes, 1997).

Estudos de monitoramento da qualidade do Rio Ribeira de Iguape, bem como de dispersão da sua carga sedimentar (Geobrás, 1966; Eysink et al. 1988; Ferreira,1994; Moraes, 1997; Silva,1997 e Corsi, 1999), apresentam um quadro que evidencia a associação de sedimentos finos de suspensão, ricos em matéria orgânica e elementos metálicos, ao longo de todo o canal fluvial, a partir do Alto Ribeira até sua foz. Todos estes estudos como também os de caracterização geoquímica dos sedimentos do sistema costeiro Cananéia-lguape (Tessler et al.,1987; Eysink et al., 1987) indicam, como fonte dos elevados teores de elementos metálicos dos sedimentos recentes do canais costeiros e fluvial, as áreas de mineração da Província Mineral do Alto Ribeira de Iguape.

\subsubsection{Histórico da mineração no Vale do Ribeira}

Não são muito precisos os registros históricos acerca das descobertas e do aproveitamento das mineralizações existentes no Vale do Ribeira. De acordo com Leonardos (1934 apud Daitx, 1996), as primeiras referências dizem respeito a mineralizações de chumbo em Iporanga no ano de 1832, muito embora indícios dessas mineralizações já fossem conhecidos no Morro do Chumbo no final do século XVIII (Daitx,1996). 
A primeira jazida de chumbo explorada economicamente foi a Mina Furnas cuja lavra teria se iniciado por volta de 1919, sendo o minério composto por galena argentífera, exportada para a Espanha (Moraes, 1997).

A Mina do Panela começou a ser explorada em 1938, com produção constante a partir de 1947 até o final dos anos 80, quando foi considerada esgotada.

Em 1934, a Companhia de Mineração Iporanga instalou a primeira usina metalúrgica para chumbo próximo as minas do Morro do Chumbo e Espírito Santo. Sua produção foi de apenas 5 toneladas do metal sendo em seguida desativada.

No início dos anos 40 foram descobertos os jazimentos do Ribeirão do Rocha e, em 1952, os da área do Paqueiro. No ano de 1969 entrou em operação a Mina do Barrinha e, em 1974, a Mina do Perau. Novos depósitos de chumbo foram descobertos somente na década de 80 , como o do Araçazeiro, Perau-SW e Canoas.

Em 1943, a empresa Plumbum S/A iniciou a instalação de uma metalurgia de chumbo na área da Mina Panelas, entrando em operação em 1945. A partir deste ano, todo minério de chumbo produzido no Vale do Ribeira foi refinado por essa empresa até o seu fechamento, em 1995.

A produção de minério de chumbo no Vale do Ribeira era significativa chegando, nos anos 80 , a ser responsável por cerca de 25 a $35 \%$ da produção nacional. Segundo o Anuário Mineral da DNPM (1986), a produção anual total de chumbo metálico produzido no Vale do Rio Ribeira, em 1985, foi de 7616 toneladas. Em 1990, a produção de chumbo sofreu forte redução em decorrência do esgotamento e fechamento de algumas minas do Vale do Ribeira, tendo a usina pertencente à Plumbum S.A. operado até o final de 1995, principalmente com minérios provenientes dos EUA, Peru, Argentina, Bolívia, Chile e Colômbia.

Segundo Daitx (1996), a produção de chumbo, prata e, secundariamente, zinco, na região do Vale do Ribeira, entre 1918 e 1995, atingiu aproximadamente três milhões de toneladas, procedentes de nove minas, sendo que seis delas eram localizadas no Estado do Paraná (Panelas, Rocha, Barrinha, Perau, Canoas e Paqueiro), e as outras três (Furnas, Lageado e Espírito Santo), no Estado de São 
Paulo. Dos minérios extraídos dessas mineralizações foram obtidos, aproximadamente, $210.000 \mathrm{t}$. de chumbo, $240 \mathrm{t}$. de prata, e de $18.000 \mathrm{t}$. de concentrado de zinco, com teores ao redor de $50 \%$, provenientes da mina de Canoas. Todos esses minérios foram processados na Usina de Beneficiamento de Panelas, no município de Adrianópolis ( $\operatorname{Pr}$ ), correspondendo a cerca de um terço da produção nacional de chumbo e prata no período de 1919 a1995.

As mineralizações da província mineral do Vale do Ribeira foram agrupadas por Fischer (1976 apud Moraes, 1997) em dois tipos principais: Panelas e Perau.

As jazidas do tipo Panelas correspondem a mineralizações epigenéticas com corpos filonares discordantes de das rochas encaixantes tendo forte controle estrutural, estando os veios mineralizados preenchendo fraturas associadas a estruturas sinformal e antiformal.

As minas do Furnas, Barrinhas e do Rocha possuem mineralizações associadas a epicalcários dolomíticos com intercalações de filitos, por vezes grafitosos, com biotita e/ou clorita e quartzo, pertencentes ao sub-grupo Lageado do Grupo Açunguí de Campanha (1991 apud Moraes, 1997).

De acordo com Daitx (1996), as jazidas do tipo Panelas apresentam feições comuns quanto a sua constituição mineralógica bastante simples do minério, praticamente formado apenas por galena e pirita, com elevado teor de prata mineralizado na forma de veios discordantes da rocha carbonática encaixante.

Tassinari et al. (1990), atribuíram a estas jazidas, com base em datações $\mathrm{Pb}-\mathrm{Pb}$ em galenas, idades entre 1,1 a 1,4 bilhões de anos.

As jazidas do tipo Perau caracterizam-se por serem singenéticas concordantes, associadas a formações ferríferas e/ou baritíferas, dispondo-se na porção inferior da Formação Perau, Grupo Setuva (Campanha, 1991 apud Moraes, 1997), com um horizonte litoestratigráfico constituído de quartzitos, rochas carbonáticas impuras e quartzo/ micaxistos com intercalações subordinadas de anfibolitos.

Tassinari et al. (1990) também através de datações $\mathrm{Pb}-\mathrm{Pb}$, em galenas, obtiveram idades entre 1,5 a 1,7 bilhão de anos, para os jazimentos do tipo Perau. 
Na mina Perau os principais minerais de minério do depósito são galena, pirita, esfarelita, pirrotita e calcopirita. Os minerais de canga são o quartzo, barita, calcita e dolomita.

Os procedimentos de extração, beneficiamento e armazenamento do minério e de seus rejeitos, ao longo das drenagens da bacia do Rio Ribeira de Iguape, se transformaram na principal fonte de aporte de elementos metálicos para os sedimentos e a biota do rios da região e para o sistema costeiro (Ferreira, 1994; Moraes, 1997; Silva, 1997; Corsi, 1999).

\subsubsection{A origem e os níveis de metais pesados na bacia de drenagem do}

\section{Rio Ribeira de Iguape.}

O enriquecimento de metais em sedimentos associados a meios aquosos pode ser originado de cinco fontes, não excludentes entre si (Goldberg,1954 apud Forstner, 1983):

- Fontes litogênicas, responsáveis pelos produtos de alteração gerados a partir de rochas presentes nas bacias de drenagem;

- Fontes hidrogênicas, correspondendo aos produtos de precipitação, substâncias adsorvidas originárias de processos de mudanças físico-química na água;

- Fontes biogênicas, cujos produtos são relacionados aos restos biológicos animais e vegetais do próprio meio, bem como de produtos de alteração de substâncias orgânicas;

- Fontes atmogênicas, cuja fonte metálica corresponderia ao aporte desses elementos a partir da chuva radioativa da atmosfera terrestre e,

- Fontes cosmogênicas constituídas por partículas extra-terrestres.

Quando os metais são sorvidos por sedimentos em meio aquoso natural, a partir de fontes naturais ou antropogênicas, sofrem complexação com ligantes orgânicos e inorgânicos. A precipitação destes metais no meio aquoso é resultado de mudanças do $\mathrm{pH}$ do meio, oxidação e também de mudanças de sua composição química. 
As principais causas da precipitação e complexão metálica estão associadas a (Salomons \& Forstner apud Corsi, 1999):

- Oxidação de componentes reduzidos tais como o ferro, manganês e sulfatos;

- Redução de metais de alta valência pela interação com a matéria orgânica (selênio, prata);

- Redução de sulfato para sulfeto (ferro cobre, prata, zinco, mercúrio, níquel, arsênio e selênio são precipitados como sulfetos metálicos);

- Reações tipo alcalina (estrôncio, manganês, ferro, zinco e cádmio são precipitados pelo aumento de $\mathrm{pH}$, ocasionado pela interação com rochas alcalinas e sedimentos, ou pela mistura com águas alcalinas);

- Adsorção ou co-precipitação de íons metálicos com óxidos de ferro e manganês, argilas e particulados de matéria orgânica e;

- Reações de troca iônica preferencialmente com as argilas.

Sendo raros no meio aquoso os processo de desagregação, volatilização, ou decaimento por fotólise dos metais, são quatro as associações entre os metais e as substâncias sólidas no meio aquático, quais sejam: adsorvidos e absorvidos (sorvidos); co-precipitados com óxidos e hidróxidos de ferro e manganês; associados à matéria orgânica e incorporados aos minerais cristalinos.

Em projetos de caráter de mapeamento geoquímico e ambiental, concentrações superiores aos níveis basais, principalmente dos metais chumbo, zinco e cobre, foram detectados na bacia de drenagem do Rio Ribeira de Iguape, por levantamentos de escala regional (Eysink et al. 1990,1991, Moraes, 1997, Silva 1997, Corsi,1999), como também de escala local (Ferreira, 1994). Níveis anormalmente elevados também foram obtidos em análises dos sedimentos dos canais do sistema costeiro Cananéia - Iguape (Tessler et al., 1987; Eysink, et al.,1987), bem como na musculatura e vísceras de animais aquáticos dos sistemas costeiro e fluvial (Eysink et.al, 1987 e Eysink et al., 1991).

Níveis elevados de metais em sedimentos de correntes devem sempre ser relacionados aos níveis basais desses elementos, no complexo rochoso que contém a bacia de drenagem considerada. 
Moraes (1997), na caracterização do transporte de chumbo e metais associados no Rio Ribeira de Iguape, adotou como níveis basais ("background" regional) os valores obtidos por um mapeamento geológico e geoquímico realizado pela CPRN (1974 apud Moraes, op.cit.), como elemento comparativo para os níveis dos

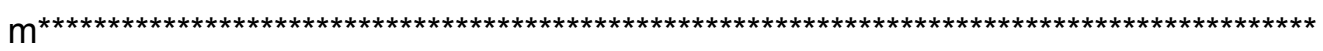

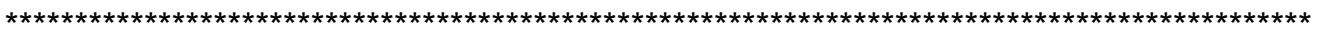

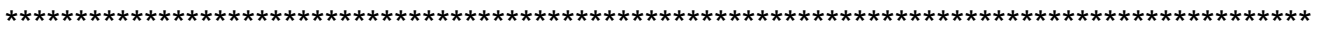

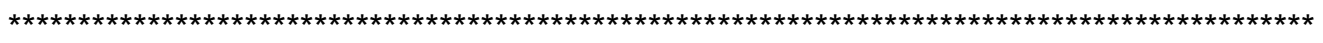

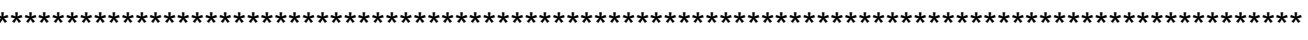
s obtidas pela CPRN (1974, apud Moraes, 1997 ) indicaram um valor de nível basal para o chumbo de $16 \mu \mathrm{g} / \mathrm{g}$, para o zinco de $47 \mu \mathrm{g} / \mathrm{g}$ e para o cobre de $18 \mu \mathrm{g} / \mathrm{g}$.

Corsi (1999), considerando um estudo executado pela JICA, para a área de influência da Mina Canoas, estima o "background" regional em 35 ppm para o chumbo e 70 ppm para o zinco.

Os primeiros estudos realizados pela CETESB (Eysink et al., 1988), na bacia do Rio Ribeira de Iguape, indicaram como um dos pontos mais críticos de contaminação dos sedimentos de corrente, por elementos metálicos, o Ribeirão do Rocha, Alto Ribeira de Iguape, na área de influência da Mina do Rocha (Pr).

A partir deste estudo (Eysink et al., 1988), os autores consideraram as minerações de chumbo, prata e zinco, a céu aberto e minerações subterrâneas, bem como as usinas de beneficiamento do Alto Ribeira, como as fontes de contaminação para todo o sistema fluvial, bem como para o sistema costeiro, em especial o Sistema Cananéia - Iguape.

Estudo geoquímico detalhado executado em sedimentos de corrente da drenagem que banha a área da Mina do Rocha (Ferreira, 1994), evidenciou níveis elevados de chumbo, cobre e zinco decorrentes das diferentes atividades antrópicas pertinentes à mineração de chumbo existentes na área. Os principais focos desse enriquecimento foram identificados como sendo a pilha de minério 
concentrado e as pilhas de rejeito e minério cominuído, todas abandonadas a céu aberto, junto a canais fluviais da bacia de drenagem do Rio Ribeira de Iguape.

Ferreira (1994) concluiu que a contribuição de chumbo para a drenagem, oriundo das atividades desenvolvidas pela mineração no Ribeirão do Rocha, aumentava em 13,2 vezes as concentrações deste elemento nos sólidos em suspensão da drenagem, em associação com óxidos e hidróxidos de ferro e manganês, seguido por carbonatos, matéria orgânica e adsorvido pelo particulado. A contribuição do cobre eqüivalia a 8 vezes os valores de referência, e os do zinco chegaram a 8,8 vezes, associados por ordem de preferência aos óxidos e hidróxidos de ferro e manganês, carbonatos, matéria orgânica e adsorvido aos particulados.

Um levantamento mais extensivo realizado por Eysink et al. (1991), ao longo de $360 \mathrm{~km}$ do canal do Rio Ribeira de Iguape, desde a divisa geográfica dos estados de São Paulo e Paraná até junto a sua foz no oceano, e no sistema costeiro, indicou a presença de elevados teores de chumbo, zinco, cobre, arsênio nos sedimentos.

Segundo Eysink et al. (1991), a empresa Plumbum lançou sem tratamento, desde 1954, no Rio Ribeira de Iguape, os resíduos originários dos processos de concentração do minério. Segundo os autores foram lançados, mensalmente, $733,2 \mathrm{~kg}$ de arsênio, $16,9 \mathrm{~kg}$ de cádmio, $50,96 \mathrm{~kg}$ de chumbo, $28,0 \mathrm{~kg}$ de cobre, $5,1 \mathrm{~kg}$ de cromo e $46,80 \mathrm{~kg}$ de zinco.

Altas concentrações de arsênio foram detectadas por Silva (1997), nos sedimentos dos canais da drenagem Ribeira de Iguape. O arsênio como subproduto do minério de chumbo, efetivamente deve ter sido enriquecido a partir dos rejeitos da mineração e do tratamento mineral, em especial dos jazimentos do tipo Panelas que se constituem nos minérios mais ricos em arsênio.

Moraes (1997), além de reafirmar os elevados teores de chumbo, cobre e zinco nos sedimentos atuais do canal do Rio Ribeira de Iguape, verificou que em duas lagoas (Nova e Laranjeiras) localizadas em Sete Barras as concentrações destes elementos metálicos, na coluna sedimentar, eram em muito superiores ao "background" regional. A coincidência das concentrações dos metais nas porções 
superiores das colunas de sedimentos destas lagoas e as obtidas nos materiais em suspensão coletadas na coluna d'água indicam que os metais são transportados associados ao material em suspensão. Este transporte se processa desde as regiões de mineração localizadas no alto Vale do Ribeira até as proximidades da desembocadura no Oceano Atlântico.

Moraes (1997) comprova a origem dos metais a partir das minerações do Alto Vale do Ribeira, baseado na similaridade das assinaturas isotópicas obtidas, a partir da análise das assinaturas isotópicas do chumbo dos sedimentos de corrente, coletados ao longo do rio, as do sistema costeiro Cananéia-Iguape e dos sedimentos de junto à foz do rio, com as assinaturas do chumbo das galenas dos depósitos do tipo Panelas.

Finalmente, um estudo sobre a dispersão de metais pesados em água e sedimentos de corrente a partir de mineralizações de chumbo, zinco e prata, realizados por Corsi (1999), nas áreas de influência das minas de Canoas, Perau e Barrinha, também conclui pela origem dos metais nos sedimentos de corrente a partir de fontes vinculadas as minerações do Alto Vale, bem como que este transporte se dá, preferencialmente, através de materiais em suspensão na coluna d'água associadas aos óxidos e hidróxidos de ferro e manganês, aos carbonatos e a matéria orgânica.

Desta forma, é inequívoca a existência de exportação de plumas de sedimentos com teores de elementos metálicos acima do nível de base regional, para as regiões marinhas rasas das proximidades da desembocadura fluvial do Rio Ribeira de Iguape. 


\subsection{Sistema Continental. Planície costeira. Sistema Cananéia - Iguape.}

\subsubsection{Fisiografia do Sistema}

No litoral sul paulista, na transição entre os sistemas continental e francamente marinho, desenvolve-se um sistema costeiro composto por um complexo de canais internos, e desembocaduras lagunares e fluviais, fortemente influenciados na sua dinâmica pelos agentes marinhos (marés e ondas), e pela drenagem continental. Esse sistema costeiro corta uma extensa planície quaternária cuja evolução foi condicionada pelas variações relativas do nível do mar, ocorridas durante o Quaternário superior.

O litoral paulista, ao sul do Rio Ribeira de Iguape, apresenta também um conjunto de ilhas, localizadas próximas ao continente (Cardoso, Cananéia, Comprida e Iguape), separadas entre si por uma série de estreitos canais que se interligam e deságuam no Oceano Atlântico através de três desembocaduras (Ararapira, Cananéia e Icapara).

Os rios que drenam a planície costeira são originários do complexo serrano próximo exibindo alto gradiente na transição dos morros para a planície, e um desenvolvimento muito suave, meandrante, na planície, apresentando, por vezes, orientação paralela à linha de costa atual. É comum nesses cursos fluviais a influência marinha a montante de sua foz por distâncias de até duas dezenas de quilômetros da linha de costa. O Rio Ribeira de Iguape é o único a apresentar influência continental até próximo a sua foz.

Este sistema costeiro, localizado a S-SE da desembocadura do Rio Ribeira de Iguape, denominado de Cananéia - Iguape, recebe águas marinhas através das desembocaduras fluviais e lagunares, e águas continentais e insulares, por meio de inúmeros rios que ali desembocam.

Segundo Tessler (1982), esses cursos de água que desembocam nos canais lagunares são de duas categorias: os rios propriamente ditos, que se localizam no continente e na ilha do Cardoso e canais de maré de água salobra existentes nas ilhas circunvizinhas. 
O sistema costeiro apresenta um alto índice de precipitação pluviométrica, com maior valor médio mensal em março e mínimo em agosto, e média anual de $2270 \mathrm{~mm}$ (Miyao et al., 1986). Segundo Schaeffer-Novelli et al. (1990), este valor excede o potencial anual de evapotranspiração da região, que é de $1656 \mathrm{~mm}$. Na região há um predomínio de massas de ar tropical no verão, com intensa precipitação pluviométrica, e de massas de ar polar no inverno, com menor precipitação.

Os ciclos de maré, associados às descargas dos rios e precipitação atmosférica, causam grande variação na amplitude da salinidade ao longo do Sistema.

A média anual da temperatura do ar é de $21,2^{\circ} \mathrm{C}$, com média de variação diária de $6,7^{\circ} \mathrm{C}$. As temperaturas mais elevadas ocorrem nos meses de janeiro, fevereiro e março, com média de $24,5^{\circ} \mathrm{C}$ para janeiro, e as menores em julho e agosto, com média de $7,8^{\circ} \mathrm{C}$ para julho.

A temperatura média da água é de $23,8^{\circ} \mathrm{C}$, com variação média diária de $7,9^{\circ} \mathrm{C}$. As temperaturas mais altas ocorrem em janeiro, com média de $27,7^{\circ} \mathrm{C}$; as mais frias em julho, com média de $19,8^{\circ} \mathrm{C}$.

O Sistema Cananéia-Iguape $\left(25^{\circ} \mathrm{S}-48^{\circ} \mathrm{W}\right)$ é separado do oceano pela llha Comprida, uma ilha barreira com aproximadamente $70 \mathrm{~km}$ de extensão tendo, como limites, ao norte e ao sul, projeções do embasamento cristalino.

$\mathrm{Na}$ sua porção central e sul o sistema apresenta uma ilha, llha de Cananéia, separada do continente por um canal denominado de Mar de Cubatão ou "Mar de Dentro", e da llha Comprida por um outro canal, Mar de Cananéia ou "Mar de Fora". Esses dois canais estão interligados, na porção mais ao sul do Sistema, por uma ampla área denominada Baía de Trapandé.

A llha de Cananéia possui extensão aproximada de $27 \mathrm{~km}$, com largura variando entre 1 e $5 \mathrm{~km}$. Os canais que a circundam possuem larguras entre 1 e 3 $\mathrm{km}$ e profundidades máximas de $20 \mathrm{~m}$, com média ao redor de 6 metros.

O Mar de Cananéia é constituído por um conjunto de meandros com um canal de circulação mais profundo (> 5 metros), se estendendo desde a Ponta do 
Arrozal, nas proximidades da desembocadura lagunar denominada de Cananéia, até a região mais a nordeste da llha de Cananéia.

As regiões mais rasas desse canal $(<5 \mathrm{~m})$ ocupam, nos meandros, posições opostas às do canal mais profundo, apresentando como elemento característico, conjunto de ilhas onde se desenvolvem manguezais, que, por vezes, se prolongam para o interior dos canais de maré que cortam as ilhas de Cananéia e Comprida. As maiores profundidades no Mar de Cananéia são encontradas em sua porção mais estreita, Ponta do Frade, correspondendo a uma feição de crescimento arenoso, a partir da Ilha Comprida, no sentido transversal ao canal, em direção à llha de Cananéia.

Próximo à cidade de Cananéia, submerso entre a llha Comprida e a llha de Cananéia, uma formação rochosa ocorre na profundidade de 7 metros, sendo esta possível interligação entre duas intrusões alcalinas aflorantes na llha de Cananéia, Morro de São João, com cerca de 120 metros de altitude, e Morrete, na llha Comprida, com cerca de 40 metros.

O canal do Mar de Cubatão, desaguadouro dos rios originados do sistema serrano próximo, é a porção mais rasa e estreita de todo o Sistema. A profundidade média deste canal é de cerca de 5 metros, chegando a apresentar maiores valores apenas na região mais a nordeste da llha de Cananéia, na confluência com a Baía de Trapandé onde, junto ao Rio Itapitanguí, são encontradas profundidades superiores a 10 metros.

A porção mais a nordeste do Sistema apresenta um único canal de separação entre o continente e a llha Comprida, denominado de Mar Pequeno, com largura variando entre 1 e $3 \mathrm{~km}$, com profundidades médias ao redor de 6 metros e $12 \mathrm{~m}$ de profundidade máxima.

Este canal, pouco meandrante, apresenta, entre sua confluência com o Mar de Cananéia até a região próxima de um afloramento alcalino denominado localmente de pedra do "Tombo" ou "Baliza", características similares às observadas ao canal do Mar de Cananéia, quais sejam, a existência de um canal mais profundo acompanhando os meandros e regiões rasas onde se ressalta um 
conjunto de ilhas arenosas de origem recente (Nanaú, Rodrigues, Galdinos, das Vacas e Grande), em processo de colonização pelo manguezal.

No sentido da desembocadura localizada a nordeste, Icapara, a partir da região da pedra do "Tombo", essa associação de regiões rasas e conjunto de ilhas não é tão evidente, como também desaparece a ocorrência de um canal único de circulação mais profundo.

Este setor está submetido à influência do Valo Grande, que atualmente descarrega, no Sistema Cananéia-lguape, enorme quantidade de água doce e elevada carga de sedimentos finos em suspensão, provenientes do Rio Ribeira de Iguape.

\subsubsection{Gênese do Sistema}

A caracterização sedimentológica e estratigráfica dos depósitos cenozóicos das planícies costeiras do litoral sul paulista é devida a Petri \& Suguio (1971, 1973). Esses autores, baseados em dados da descrição de dois poços profundos de sondagem e em dados geofísicos, subdividiram os depósitos cenozóicos em quatro seqüências, relacionadas a eventos de oscilação do nível marinho do Quaternário (Figura 5).

A seqüência inferior (seqüência I), é constituída por areias e sedimentos conglomeráticos com corpos de argila arenosa subordinados. Sobrepostos a estes depósitos estão presentes sedimentos finos, argilas siltosas muito ricas em diatomáceas e pobres no conteúdo de foraminíferos. Estas características conferem a esta seqüência (II), um ambiente deposicional de águas salobras intermediário entre os ambientes marinho e continental.

As seqüências de topo (seqüências III e IV) são constituídas por areias siltosas de origem marinha (III), evidenciadas pela presença de abundantes foraminíferos bem preservados, sobrepostos por areias muito finas, bem selecionadas e muito friáveis (IV). A seqüência de topo (IV), de idade quaternária, é composta por sedimentos arenosos inconsolidados, bem selecionados, e apresenta pequena espessura e larga distribuição regional, sobreposta a 
sedimentos síltico-arenosos de ambientes mistos, foi designada por Petri \& Suguio (1971, 1973), de Formação Cananéia.

Posteriormente, Suguio \& Martin (1978) e Martin \& Suguio (1979), redefiniram o conceito da Formação Cananéia ampliando seus limites para toda seqüência sedimentar quaternária (seqüências de II a IV), composta de uma seqüência argilo-arenosa na base e arenosa no topo, diretamente relacionada aos eventos de oscilação do nível do mar no Pleistoceno (Transgressão Cananéia 120.000 anos A.P.).

Os eventos posteriores de variação relativa do nível do mar, designados por Suguio \& Martin (1978) de Transgressão Santos (Holoceno), retrabalharam os sedimentos de topo da Formação Cananéia, gerando a configuração das atuais planícies de cordões litorâneos do litoral paulista, com seus sedimentos contribuindo para a formação das modernas praias, dunas e sedimentos de fundo dos ambientes transicionais (lagunas, estuários) e oceânicos.

De acordo com Suguio \& Martin (1978), a gênese desta planície costeira está diretamente vinculada aos mecanismos de variação do nível marinho ocorrido ao longo do Quaternário Superior, quando nos máximos transgressivos do Pleistoceno (Transgressão Cananéia - 120000 anos A.P.) e do Holoceno (Transgressão Santos - 5100 anos A.P.), a área foi, parcialmente, recoberta pelas águas marinhas que atingiram respectivamente, cotas entre 8 e 10 metros, acima do nível atual, no evento pleistoceno e, entre 4 e 5 metros, no evento holocênico (Figura 6).

No intervalo entre os máximos transgressivos, com o recuo pronunciado do nível marinho (-130 metros), que expôs totalmente a atual planície costeira, foram depositados cordões arenosos sobre um conjunto de sedimentos argilo-arenosos transicionais e areias litorâneas transgressivas.

Neste evento regressivo que teve seu máximo à de cerca 17000 anos A.P., os sedimentos expostos sofreram erosão e originaram os vales que, posteriormente, durante o evento transgressivo subseqüente, foram afogados $e$ transformados em extensas lagunas onde se depositam sedimentos argiloarenosos, ricos em matéria orgânica. Ainda, durante este evento, ocorreu erosão 
das porções mais elevadas dos cordões arenosos pleistocênicos possibilitando a ressedimentação holocênica desses materiais erodidos.

A partir do máximo transgressivo holocênico, quando a linha de costa recuou para seu nível atual, originaram-se os cordões arenosos regressivos holocênicos de grande representatividade na llha Comprida. Durante este evento, a Ilha Comprida foi alargada pelo acréscimo de cordões litorâneos, bem como alongada, rumo a NE, pela ação associada das correntes de deriva litorânea ocasionando o isolamento, à retaguarda da linha de costa atual, o Sistema Cananéia-Iguape (Figura 7).

\subsubsection{A hidrodinâmica nos canais}

O Sistema Cananéia-Iguape apresenta, ao longo de seus canais, um padrão hidrodinâmico fortemente influenciado pelas correntes geradas pelas oscilações da maré e, em menor proporção, pela influência das descargas de água doce que adentram o Sistema.

A ação da maré no Sistema é a principal responsável pelos processos de mistura e pelas trocas que se efetuam entre o oceano e o estuário, atuando efetivamente no transporte de sedimentos e na renovação das águas estuarinas (Myao et.al.1986).

A propagação da onda de maré em torno da llha de Cananéia ocorre a partir da desembocadura situada ao sul da cidade de Cananéia. Quando a onda de maré enchente penetra no Sistema, ao sul da região, ocorre uma divisão do fluxo, com um dos ramos se propagando rumo a NE, pelo canal do Mar de Cananéia (Figura 8).

Ao norte da llha de Cananéia, na junção dos mares de Cubatão e Cananéia, recompõe-se um fluxo único que se desloca rumo à Iguape, na direção do fluxo de enchente que penetra, no Sistema, pela desembocadura de Icapara e, que se propaga no sentido sul. Estas correntes de sentidos de propagação contrários acarretam, quando de seu encontro nas proximidades da "Pedra do Tombo", o fenômeno hidrodinâmico conhecido como "tombo das águas" ou 
alternância de fluxos. O processo de vazante tem início nas saídas das desembocaduras com reflexos quase imediatos na região do "tombo" (Figura 8).

Nos períodos em que o Rio Ribeira de Iguape lança suas águas no sistema costeiro, através do Valo Grande, o fenômeno do "tombo" é revestido de maior significado, na medida em que o volume de água que penetra nos canais internos, pela desembocadura de Icapara, é acrescido pelas águas continentais que afluem através do Valo Grande. Este fenômeno hidrodinâmico tem forte significado sobre a sedimentação do canal do Mar Pequeno, especialmente como condicionante do transporte e deposição dos sedimentos finos, carreados em suspensão pelas águas continentais, que adentram o Sistema Cananéia-lguape (Tessler et al., 1987).

\subsubsection{Caracterização textural dos sedimentos de fundo dos canais}

Os sedimentos de superfície de fundo dos canais se apresentam, segundo a classificação de Shepard (1954), compostos predominantemente de sedimentos arenosos (Kutner, 1962; Tessler, 1982). Sua distribuição evidencia o predomínio de sedimentos arenosos ao longo do Mar de Cananéia. Essa mesma tendência é observada ao longo do Mar de Cubatão, Mar Pequeno e na Baia de Trapandé (Figura 9).

Alterações neste predomínio de fácies arenosas são identificadas apenas em pequenas áreas ao longo dos canais. Esse fato acentua-se próximo à cidade de Cananéia, no Mar de Cananéia, onde ocorre um afunilamento do canal e principalmente junto às ilhas do Boqueirão, na foz do córrego do Jardim, onde o canal principal de circulação meandra, aproximando-se da llha Comprida e da llha de Cananéia, possibilitando a existência de regiões mais rasas, de circulação menos intensa.

Na Ponta do Frade, junto à margem da llha Comprida, fora do canal de circulação mais profundo, existe uma reentrância da margem do canal que possibilita a formação de uma zona de baixa energia com conseqüente deposição de material muito fino. 
Na porção central da Baía de Trapandé, onde se encontra o canal de circulação mais profundo, é observada a progradação de sedimentos, com o predomínio de sedimentos arenosos (areia argilosa), junto à llha do Cardoso, migrando para sedimentos com teores mais altos de pelitos (argila siltosa e silte argiloso), junto à Ilha de Cananéia. Esse padrão é indicativo da ocorrência de uma ação hidrodinâmica mais intensa, na margem junto à llha do Cardoso, em contraste a fluxos de menor intensidade na região central da Baía de Trapandé. Esta área que recebe mais diretamente o fluxo dos cursos fluviais do complexo serrano próximo (rios Taquarí, das Minas e Itapitanguí) evidencia, não apenas a importância dessas drenagens no aporte de sedimentos finos ao sistema costeiro, mas, principalmente, no estabelecimento de um padrão de deposição desses sedimentos em função das características hidrodinâmicas do Sistema.

Na região mais a nordeste, a partir da pedra do "Tombo", em direção à cidade de Iguape, a característica geral observada nos demais segmentos dos canais se altera, passando a predominar sedimentos pelíticos (argilas siltosas e siltes argilosos). Na região próxima à pedra do "Tombo", misturas equivalentes de sedimentos grossos e finos são encontradas ao lado de sedimentos arenosos, configurando a existência de variações nos fluxos de energia. Esse padrão de alternância de fluxos ("tombo das águas") permite a deposição de sedimentos finos, especificamente aqueles carreados em suspensão a partir do Rio Ribeira de Iguape, através do Valo Grande.

Em direção a lguape os sedimentos encontrados são progressivamente mais finos, com a formação de ilhas dispostas longitudinalmente ao canal. Esse padrão é observado até próximo do Rio Sorocabinha quando novamente se apresentam misturas de sedimentos grossos e finos denotando, para esta porção do canal, uma condição hidrodinâmica semelhante à encontrada na região do "Tombo".

A região da desembocadura de Icapara com sedimentação predominantemente arenosa, bem como esse mesmo predomínio na porção central do canal junto à foz do Valo Grande, sugere a predominância de um fluxo residual no sentido da desembocadura para a pedra do "Tombo". 
Tessler \& Souza (1998), considerando as formas de fundo identificadas nos canais através de cenografia de varredura lateral, concluíram que as pequenas deformações de fundo, rugosidades características de fluxo bidirecional, com as suas maiores dimensões dispostas transversalmente ao fluxo médio com pequenas ondulações paralelas a esse fluxo, são indicativas de condições hidrodinâmica de baixa energia para o transporte sedimentar de fundo, para todo o Sistema. Porém, as formas de maior expressão identificadas apenas no canal do Mar Pequeno, são indicativos que as correntes de vazante apresentam uma maior competência na remobilização de fundo, neste segmento dos canais.

\subsubsection{Caracterização geoquímica dos sedimentos}

A caracterização geoquímica dos sedimentos de fundo dos canais internos do Sistema Cananéia - Iguape, particularmente quanto à distribuição da matéria orgânica total e do conteúdo de carbono e nitrogênio, demonstra uma relação direta entre teores mais elevados destes componentes orgânicos contidos nos sedimentos, com as áreas de deposição preferencial de sedimentos lamosos, nas regiões hidrodinâmicas de menor energia do sistema (Maglioca \& Kutner, 1964; Bini \& Vera, 1995).

Esta relação de interdependência também foi verificada com respeito aos teores de metais pesados, em especial do chumbo, contidos nos sedimentos de fundo dos canais (Tessler et al., 1987; Eysink et al., 1988). Porém, enquanto que, para os componentes orgânicos, os teores mais elevados encontram-se presentes ao longo de todos os canais do sistema, os elementos metálicos apresentam teores anormalmente elevados no segmento do canal compreendido entre a região da pedra do "Tombo" e o Valo Grande que, associados aos sedimentos lamosos e ricos em matéria orgânica, são carreados em suspensão pela drenagem Ribeira e lançados nos canais através do Valo Grande (Tessler et al., 1987).

Neste segmento do canal do Mar Pequeno, que corresponde à área de encontro das correntes de marés com sentidos de propagação opostos, ocorre a deposição da quase totalidade dos sedimentos em suspensão. Este fenômeno 
associado aos momentos de reversão entre os ciclos de maré enchente e vazante (estofa da maré), além de induzir a uma deposição da carga em suspensão, impede a livre propagação desses sedimentos finos supridos pelo rio Ribeira para todos os canais lagunares. Portanto, com teores variando entre $0,30 \mu \mathrm{g}$ a 246,80 $\mu \mathrm{g}$ de $\mathrm{Pb}$ por grama de sedimento seco, ao longo de todo o Sistema, os teores de metais pesados encontrados nos sedimentos de fundo, coletados ao longo das demais segmentos dos canais, não apresentaram concentrações tão elevadas quanto as obtidas para o Mar Pequeno ( $\mathrm{Pb}>260 \mu \mathrm{g} / \mathrm{g})$.

Teores de chumbo total mais elevados só foram observados nas faces côncavas do Mar de Cananéia $(\sim 24 \mu \mathrm{g} / \mathrm{g})$, e representam a deposição de sedimentos não depositados na região do Mar Pequeno, durante os eventos de estofa da maré, e transportados em direção à desembocadura de Cananéia por correntes de maré vazante.

Os metais zinco e cobre também apresentaram teores totais mais elevados ao longo do Mar Pequeno, associados aos sedimentos lamosos ricos em matéria orgânica. Os teores de zinco variaram entre 1,4 e 105,8 $\mu \mathrm{g} / \mathrm{g}$ e o cobre entre 0 (abaixo do limite de detecção do método de análise utilizado) até valores superiores a $290 \mu \mathrm{g} / \mathrm{g}$ de sedimento seco.

Análises químicas dos metais chumbo, cobre e zinco, executados por Saito (1999), ao longo das colunas sedimentares de quatro testemunhos rasos coletados nos canais do Sistema Cananéia - Iguape indicaram variações verticais dos elementos, mas correspondentes, em ordem de grandeza, aos valores obtidos para o topo das seqüências sedimentares. Estes resultados obtidos confirmam a persistência do padrão de sedimentação atual ao menos durante o período de tempo amostrado que, de acordo com o autor, corresponderia a um período deposicional mínimo de 38 anos para o testemunho do Mar Pequeno (Valo Grande), e de no máximo de 90 anos para o testemunho coletado no Mar de Cubatão, junto à foz do rio Carapara. 


\subsubsection{Taxas de sedimentação}

Estudos acerca de taxas de sedimentação recentes no Sistema Cananéia Iguape foram desenvolvidos por Saito et al. $(1997,1999)$, baseados na detecção dos níveis de radionuclídeos naturais $\left({ }^{210} \mathrm{~Pb},{ }^{210} \mathrm{Bi}\right)$ e antropogênicos $\left({ }^{137} \mathrm{Cs}\right)$, por espectrometria gama, em testemunhos rasos obtidos ao longo dos canais.

O valor mais elevado de taxa de sedimentação, obtido para um período deposicional correspondente aos últimos 34 anos, (12,7 mm/ano), está associado ao canal do Mar Pequeno, correspondendo à área deposicional mais diretamente vinculada à influência da drenagem Ribeira de Iguape, próximo à desembocadura do Valo Grande.

A taxa obtida para a porção mais ao sul da área, correspondendo ao canal do Mar de Cananéia, nas proximidades da desembocadura homônima (Ponta do Arrozal), apresentou similaridade entre os valores obtidos para a curva de decaimento do ${ }^{210} \mathrm{~Pb}(5,30 \mathrm{~mm} / \mathrm{ano})$, com o valor calculado a partir da curva de decaimento do ${ }^{137} \mathrm{Cs}(5,45 \mathrm{~mm} / \mathrm{ano})$. Ainda no Mar de Cananéia, junto à área deposicional à retaguarda da Ponta do Frade, os autores obtiveram taxas intermediárias entre as obtidas para a Ponta do Arrozal e Valo Grande (9,8 $\mathrm{mm} / \mathrm{ano}-{ }^{210} \mathrm{~Pb}$ ). Este resultado, associado às curvas de distribuição dos teores de metais obtida do testemunho da Ponta do Frade indica que a área dos canais atua como receptora dos sedimentos lamosos, originários da drenagem Ribeira de Iguape, transportados pela corrente de vazante, em direção a Cananéia, após a fase de estofa da maré no canal do Mar Pequeno.

O canal mais interno, Mar de Cubatão, amostrado na desembocadura do Rio Carapara, indicou taxa de sedimentação da ordem de 6,22 mm/ano $\left({ }^{210} \mathrm{~Pb}\right)$. Este valor, pouco superior ao obtido para a Ponta do Arrozal demonstra que, muito embora a taxa de sedimentação, nas áreas mais ao sul dos canais, apresente um valor muito inferior à da região do Valo Grande, a drenagem do Maciço Mandira, que deságua na porção mais ao sul da área, carreia para os canais do Mar de Cubatão e da Baía de Trapandé, quantidades consideráveis de material em suspensão, com baixos teores de metais pesados. 


\subsection{Sistema Marinho}

\subsubsection{0rigem e evolução tectônica da margem continental sudeste}

brasileira

A Margem Continental Sudeste brasileira tem sua gênese e evolução geológica vinculada aos processos mesozóicos/cenozóicos de desenvolvimento das margens do Tipo Atlântico e, consequentemente, da origem e evolução do Oceano Atlântico, cuja evolução geotectônica condiciona toda a costa leste sulamericana.

De acordo com Almeida (1976), entre o final do Cretáceo e o Eocenozóico, a margem continental sul atlântica foi submetida a processos de reativação tectônica marcados por intenso magmatismo de natureza alcalina, ao qual se seguiram extensos processos de falhamentos de blocos evidenciados, no continente, por numerosos eventos, como o soerguimento do complexo da Serra do Mar, a formação das bacias tectônicas ("rifts") do Paraíba do Sul e da Guanabara e, na área oceânica, pela Falha de Santos e pela subsidência da Bacia de Santos (Figura 10).

O desenvolvimento da Bacia de Santos teve seu início durante o Aptiano, com a invasão do mar no "rift" original, ocasionando a deposição de evaporitos sobre a lava basáltica do Cretáceo inferior (Almeida, 1976).

Em subsidência progressiva, a Bacia de Santos acumulou espesso pacote de sedimentos, originários basicamente da erosão da proto Serra do Mar, que assumiu posição semelhante à atual apenas ao final do Terciário. A partir de informações obtidas através de perfurações de sondagem, realizadas pela Petrobrás, na margem continental sudeste brasileira, Almeida \& Carneiro (1998) indicam a possibilidade desta subsidência ter prosseguido até o PliocenoPleistoceno, com um acúmulo de sedimentos de cerca de $8 \mathrm{~km}$ e reflexos sobre o continente. Almeida (1976) indica, como um destes reflexos, a possível existência de uma linha de inflexão na região de transição entre o continente e o oceano, produto de balanceamento entre uma zona positiva sobre o continente e negativa no mar. As diferenças entre estes mecanismos ao longo da direção N/S poderiam 
ser a explicação das diferenças morfológicas existentes entre as diversas planícies costeiras do litoral do Estado de São Paulo (Souza, 1995).

Evidências da existência de um tectonismo mais recente (Cenozóico), na margem continental leste brasileira, particularmente no litoral sul paulista, têm sido bastante restritas, embora existam indicativos da ocorrência de condicionamento tectônico na formação recente da costa sudeste do Estado de São Paulo (Fúlfaro et al., 1974; Teissedre et al., 1981; Riccomini et al., 1987, Pressinoti \& Pressinoti, 1980 e Souza et.al. 1996).

Em suas fases evolutivas mais recentes, superimposto ao controle morfotectônico mesozóico-cenozóico da margem continental leste, ocorreram variações relativas do nível do mar quaternárias (eventos Cananéia e Santos), que levaram ao remodelamento da plataforma continental com fases de exposição e submersão de extensas áreas.

Ao longo do processo de dissecação, houve também o desenvolvimento de uma extensa rede de canais e vales submarinos sobre a plataforma e o talude continental (canais de Queimada, Cananéia, São Sebastião, etc e os vales submarinos de São Paulo e Rio de Janeiro). Algumas dessas feições, desenvolvidas em situações de nível relativo do mar mais baixo que o atual, ainda apresentam expressão topográfica no fundo marinho recente. Furtado et al. (1993), identificaram paleosuperfícies erosivas, vales colmatados, escarpas bem marcadas e um vale submerso, na entrada sul do Canal de São Sebastião, que se estende para regiões mais profundas da plataforma. Este vale havia sido identificado anteriormente por Zembruscki (1979), que associou sua gênese a períodos regressivos e erosão subaérea.

\subsubsection{Fisiografia e Morfologia do fundo (Embaiamento de São Paulo)}

A unidade fisiográfica que se estende do Cabo Frio (RJ) até o Cabo de Santa Marta Grande (SC), foi denominada por Butler (1970), como Embaiamento de São Paulo. Nesta unidade a plataforma continental apresenta largura variável entre 73 e $231 \mathrm{~km}$, declividade entre 1:656 e 1:1333 e uma profundidade de quebra da plataforma situada entre 120 e 180 metros. De uma forma geral, as 
isóbatas aproximam-se entre si em direção ao norte e, nas proximidades do Cabo Frio, a plataforma apresenta sua menor largura.

Zembruscki (1979), analisando a fisiografia submarina do Embaiamento de São Paulo definiu, para a área, a compartimentação da plataforma continental (interna, média e externa), baseada nas mudanças de declividade observada. $\mathrm{Na}$ plataforma continental do Estado de São Paulo, esta compartimentação apresenta características de paralelismo entre os compartimentos e a atual linha de costa. Este padrão geral é modificado na plataforma continental localizada ao norte da Ilha de São Sebastião.

Ao norte da llha de São Sebastião, a plataforma média cede lugar a uma escarpa média, sendo que ambas apresentam seu limite externo, na área, na isóbata de 100 metros. Na área ao norte da llha de São Sebastião, Costa et al. (1988), evidenciaram a presença de escarpas a profundidades de $60 \mathrm{~m}, 110 \mathrm{~m}$ e $130 \mathrm{~m}$, relativas ao nível do mar atual.

A Ilha de São Sebastião representa um notável marcador geomorfológico não somente da linha de costa, como da plataforma continental. Nesta área ocorre uma alteração na direção geral da linha de costa, que passa de SW-NE, ao sul da Ilha, para W-E, a norte. Também, ao norte da Ilha de São Sebastião, os recortes do litoral e a presença de várias ilhas tornam mais complexa a geomorfologia regional. Este trecho da margem continental apresenta alguns cânions e canais submarinos (Búzios, São Sebastião, Queimada), porém com pouca expressão na topografia de fundo atual (Furtado et al., 1996).

Ao sul de São Sebastião a presença de canais na plataforma continental interna e média sul paulista não é muito evidente, possivelmente em decorrência da colmatação dos paleocanais pelas areias transgressivas holocênicas. A existência de uma plataforma larga, com baixos declives, é indicativa de um processo sedimentar de expressão, vinculado ao retrocesso erosivo da Serra do Mar, que resultou na suavização da topografia de fundo e na progradação da plataforma continental. Uma alteração neste padrão geral é encontrada nas plataformas interna e média, entre Santos e a região da Juréia, onde se destaca um canal que se estende desde as proximidades da linha de costa até o talude 
superior. De acordo com Furtado et al. (1996), este canal pode representar a via preferencial tanto para o ingresso de águas de plataforma para a região costeira, como também o canal de exportação de sedimentos das regiões costeiras para o oceano profundo.

Corrêa (1979) e Corrêa et al. (1980,1989), a partir da análise de cartas batimétricas de detalhe da plataforma continental localizada entre o Rio de Janeiro e o Rio Grande do Sul, identificaram feições aplainadas as quais os autores associaram fases de estabilizações do nível relativo do mar do evento quaternário, posterior ao Último Máximo Glacial.

Estas feições de estabilização situam-se, atualmente nas profundidades de $20 \mathrm{~m}$ a $25 \mathrm{~m}, 32 \mathrm{~m}$ a $45 \mathrm{~m}, 60 \mathrm{~m}$ a $75 \mathrm{~m}$ e entre $80 \mathrm{~m}$ e $90 \mathrm{~m}$. Corrêa et al. (1980), propuseram as idades de 7.000 anos A.P., 9.000 anos A.P., 10.000 anos A.P., 11.000 anos A.P. e 11.500 anos A.P., respectivamente para os níveis supracitados.

Furtado et al. (1992) definiram, para a plataforma continental de São Paulo, cinco áreas de feições aplainadas, às quais os autores relacionaram períodos de estabilização do nível marinho transgressivo do quaternário superior. $O$ primeiro intervalo, de 15 a $20 \mathrm{~m}$ estaria relacionado ao período atual, o segundo intervalo, situado entre 30 e $40 \mathrm{~m}$, corresponderia a 9.000 anos A.P. O terceiro intervalo, situado entre 60 e $70 \mathrm{~m}$ e o quarto, entre 80 e $100 \mathrm{~m}$, correspondendo respectivamente, a idades de 11.000 anos A.P e entre 11.000 anos A.P. e 12.000 anos A.P. O quinto nível, mais externo e antigo, situado a $130 \mathrm{~m}$ de profundidade, corresponderia a um nível datado para o Rio Grande do Sul de 17.420 anos A.P. $+/-270$ anos.

Localizada a uma profundidade variável entre 120 e 160 metros, na área de estudo, a Quebra da Plataforma marca a transição entre a Plataforma Continental e o Talude Continental. Este, por sua vez, estende-se, com uma declividade entre $1^{\circ}$ e $1^{\circ} 45^{\prime}$ até aproximadamente a isóbata de 2000 metros na área, onde dá lugar a uma notável feição morfológica do Atlântico Sul, o Platô de São Paulo.

O Platô de São Paulo é uma feição fisiográfica que se desenvolve, para norte, para além dos limites do Embaiamento de São Paulo. Entretanto, a porção 
a norte do Cabo Frio constitui um prolongamento suave do platô que vai retirando aos poucos, sua condição de unidade fisiográfica do tipo platô marginal (Zembruscki, 1979). A porção do Platô adjacente à área de estudo caracteriza-se como uma unidade de relevo que se estende entre as isóbatas de 2000 e 3600 metros e é subdividida em dois patamares bem característicos - superior e inferior - separados por uma escarpa limitante a 2900 metros de profundidade. A origem e evolução do Platô de São Paulo, que determinaram seu relevo, são fortemente condicionadas por intenso diapirismo salino que, aparentemente, é ativo até os dias atuais (Baccar, 1970 apud Zembruscki, 1979).

\subsubsection{Dinâmica das massas d'água na margem continental sudeste I} sul do Brasil

A dinâmica das massas d'água na margem continental sudeste / sul brasileira é resulta da interação de três massas d'águas principais: Água Costeira (AC); Água Tropical (AT) e Água Central do Atlântico Sul (ACAS), que apresentam sazonalidade acentuada em seus deslocamentos sobre a plataforma continental. (Castro Filho et al., 1987).

Esta sazonalidade se manifesta com a penetração, nos meses de verão, da ACAS, massa de água fria e mais densa, junto ao fundo marinho, do oceano profundo em direção à região costeira. Esta penetração induz ao deslocamento das águas menos densas da $A C$ até porções mais externas da plataforma continental, mantendo a AT relativamente distante da linha de costa.

Como o período do verão também corresponde à fase das maiores precipitações pluviométricas, no litoral paulista e, portanto, de maior competência dos sistemas fluviais, o processo dinâmico de deslocamento das águas superficiais pode representar, potencialmente, o período de maior exportação de sedimentos terrígenos em suspensão e matéria orgânica em direção às áreas oceânicas (Mahiques et al., 1998).

Ao final do verão e, mais pronunciadamente nos meses de inverno, com o recuo da ACAS, em direção à plataforma externa e ao talude superior, a AT passa 
a desempenhar maior influência sobre a plataforma continental, e a AC não mais se projeta para os setores mais externos da plataforma.

Nas porções mais externas da plataforma continental, no talude e nas áreas mais profundas parece haver uma maior estabilidade na dinâmica das massas d'água (Mahiques et al., 1999). A AT exerce sua influência até profundidades da ordem de 200 metros e é transportada pela Corrente do Brasil ao longo da Quebra da Plataforma, seguida pela ACAS, que se estende até cerca de 600 metros de profundidade e marca o desenvolvimento de uma termoclina pronunciada. Abaixo da ACAS deslocam-se, em seqüência, para o norte, a Água Intermediária Antártica (AIA), até cerca de 2.500 metros de profundidade; para o sul a Água Profunda do Atlântico Norte (APAN), entre 2.500 até 3.500 metros e; para o norte, a Água Antártica de Fundo (AAF), entre 3.500 até o fundo das bacias oceânicas (Mahiques et al., 1999).

Ainda com referência à dinâmica das massas d'água na margem continental sudeste /sul do Brasil, Mahiques et.al. (no prelo), indicaram existir um mecanismo de deslocamento vortical, de sentido horário, da Corrente do Brasil no Embaiamento de São Paulo, similarmente ao padrão de meandramento convoluto observado por Campos (2000, apud Mahiques, op.cit.) para a Corrente do Brasil na região de Cabo Frio (Figura 11). As razões deste meandramento estariam ligadas a mudanças de orientação da linha de costa, ao sul de Cabo Frio, que dinamicamente favoreceriam a formação dos meandramentos de giro horário da $\mathrm{CB}$, como uma tentativa de conservação do momento angular. A conseqüência seria então a formação de uma estrutura em vórtice com ascensão de massa d'água associada às áreas do sul do vórtice e mergulho de águas nas áreas a norte do giro.

"Em outras palavras o fluxo que cruza a plataforma, relacionado ao meandramento da Corrente do Brasil, controla o processo na plataforma externa e talude superior no embaiamento de São Paulo. Desta maneira, parece razoável supor que os processos sedimentares sobre a plataforma média e externa sejam alterados pelo meandramento da Corrente do Brasil, a qual fricciona ela mesma contra a superfície do fundo da plataforma (Mahiques et.al., no prelo). 


\subsubsection{Dinâmica das correntes costeiras}

Na plataforma continental interna, a este padrão geral de dinâmica das massas d'água, se superimpõe a dinâmica costeira, fortemente controlada pela circulação atmosférica do Atlântico Sul. Neste setor, a interação dos trens de ondas com o fundo oceânico raso, com a conseqüente geração de correntes, é o principal agente de movimentação de sedimentos junto ao fundo marinho raso.

No Atlântico Sul são dois os sistemas de massa de ar que predominam e condicionam a circulação atmosférica da área e, por conseqüência, os sistemas de ondas que se propagam para o litoral sul paulista, a partir dos centros de geração, localizados no oceano distante. Segundo Fonzar (1994), estes sistemas são o Anticiclone Tropical Atlântico (ATA) e os Anticiclones Polares Migratórios (APM).

O ATA, cujas pressões máximas oscilam entre 1020 e 1023 mb, gera os ventos alísios, os quais vão tomando as direções NE e NW entre $10^{\circ}$ e $40^{\circ}$ de latitude sul. Dependendo do giro desta célula regional, sua ação favorece as temperaturas elevadas e a estabilidade do tempo.

Dada a localização do ATA, a leste da costa, os sistemas de ondas, gerados pelos ventos anti-horários que dela se originam, ao atingirem a linha de costa, de orientação geral NE-SW, ocasionam a geração e propagação de correntes de deriva litorânea de rumo geral para sudoeste.

Porém, esta situação é modificada pelo deslocamento das frentes polares relacionadas ao APM. O desenvolvimento dos sistemas frontais provoca perturbações frontais que acarretam, ao lado de intensas precipitações pluviométricas, mudanças na direção dos ventos predominantes, que passam a soprar dos quadrantes a sul.

Esses sistemas de ventos são os responsáveis pelo predomínio de trens de ondas de SW e SE, geradoras de correntes de deriva litorânea que percorrem a costa no rumo geral nordeste.

O deslocamento dos sistemas frontais, ao longo do litoral sul/sudeste/leste, induz a ocorrência de ciclos de ventos de rotação horária. Em conseqüência, pode ocorrer que, para um determinado segmento da costa, em situação de pré-frontal, 
a incidência de ondas de SW induza uma corrente de deriva litorânea para nordeste. Com o deslocamento do sistema frontal para menores latitudes, o mesmo segmento da costa passa a ser atingido por ondas de nordeste, que resultam em correntes de deriva de sentido de deslocamento oposto, para sudoeste (Figura 12).

Segundo Tessler (1988), estando os centros de geração das ondas que incidem sobre o litoral sul paulista, vinculados aos ventos alísios e às frontogêneses, localizados distantes da linha de costa e, sendo estes trens de ondas dotados de níveis de energia variados e de velocidades de propagação diferentes, verifica-se que conjuntos de ondas gerados em momentos distintos podem chegar simultaneamente à costa.

Bomtempo (1993), a partir dos levantamentos de parâmetros hidrodinâmicos executados na região da Juréia (SP), concluiu pela inexistência de uma concentração de direções preferenciais de incidência de ondas em períodos determinados do ano. Identificou, também, a existência de um padrão de alternância de correntes costeiras, com sentidos opostos de propagação.

Ainda segundo Bomtempo (op. cit.), a combinação do alinhamento da costa, dos ventos predominantes e do ângulo do ataque das ondas, geraria correntes preferencialmente voltadas para sudoeste. Porém, a partir da atuação de sistemas frontais polares, em situações de pré-frontais e frontais, ocorreria o predomínio dos ventos e trens de ondas dos quadrantes a sul resultando em alterações dos ângulos de incidência das ondas em relação à costa, originando correntes de deriva litorânea direcionadas para nordeste.

As medições de correntes, realizadas entre 1982 e 1985, indicaram correntes com velocidades, em superfície e próximas ao fundo, variando entre 10 e $30 \mathrm{~cm} / \mathrm{s}$, tanto direcionadas para nordeste como para sudoeste (Bomtempo, 1993). Os valores obtidos são suficientes para o transporte de sedimentos por tração, de diâmetros máximos equivalentes a areia fina como, também, para a manutenção e o deslocamento da carga detrítica e orgânica em suspensão.

Tessler (1988), a partir de observação de imagens aéreas, pode constatar a ocorrência simultânea da incidência de trens de ondas de direções opostas, sobre 
um segmento da linha de costa, demonstrando a interação espaço-temporal de correntes de deriva costeira, com rumos opostos, nordeste e sudoeste, no litoral sul do Estado de São Paulo.

Este fenômeno é mais evidente na área de desembocadura do Rio Ribeira de Iguape que, ao causar a interrupção das correntes de deriva pelo efeito de molhe hidráulico de suas águas, interrompe o transporte arenoso ao longo da costa, acarretando a formação de feições arenosas com sentidos opostos de crescimento (Tessler, 1988).

\subsubsection{Transporte de sedimentos em suspensão}

São inexpressivas as observações e medições sobre a movimentação de sedimentos em suspensão no litoral sul do Estado de São Paulo, bem como da importância deste transporte na circulação geral da área.

A observação de uma imagem MSS do satélite LANDSAT, nos canais 4 e 5, obtida no dia 26/06/76, permite uma avaliação de pelo menos uma situação geral da circulação em superfície, para todo o sul do Estado de São Paulo (Tessler, 1988).

Nesta imagem orbital é observada a nítida presença de plumas de material em suspensão entre a Praia Grande e o Morro da Juréia, com rumo de deslocamento para SW, além de outras menos nítidas, com o mesmo rumo de deslocamento, em toda a área costeira compreendida entre Santos e a Barra do Rio Ribeira de Iguape.

Nas proximidades da foz do Ribeira de Iguape, e da desembocadura lagunar de Icapara, podem também ser observadas plumas de material em suspensão localizadas distantes da linha de costa.

Na porção média da Ilha Comprida, também é observada, ortogonal à costa e direcionada para o mar aberto, uma nítida pluma de sedimentos, associada a uma outra pluma, posicionada próxima à desembocadura lagunar de Cananéia, com sentido de deslocamento para NE, ou seja, com sentido de deslocamento paralelo à llha Comprida (Figura 13). 
O trabalho de Bonetti Filho (1995) é o único estudo que, além de identificar plumas de suspensão, no litoral sul paulista, apresenta medidas da concentração dos sedimentos em suspensão nas plumas identificadas.

Seus levantamentos temporais nas plumas associadas à desembocadura lagunar de Cananéia comprovam o sentido de deslocamento preferencial das mesmas rumo a NE, contendo sedimentos em suspensão de até $120 \mathrm{mg} / \mathrm{l}$.

A partir da análise da imagem orbital de 1976, Tessler (1988) considerou a existência de dois sistemas de transporte de material em suspensão, de sentidos de deslocamentos opostos, ao longo do litoral sul paulista.

O primeiro que se desenvolve, preferencialmente, entre Santos e a foz do Rio Ribeira de Iguape, com sentido de deslocamento SW, e um segundo que se desloca no sentido nordeste entre a desembocadura lagunar de Cananéia e a foz do Ribeira. Entre a extremidade norte da llha Comprida e a foz do Ribeira de Iguape, ocorreria uma área de transição com as plumas direcionadas para o mar aberto (SE).

A pluma da porção média da llha Comprida representa um fluxo que se desloca rumo ao mar aberto, à semelhança das correntes de retorno ("rip currents"), implicando no transporte de sedimentos em suspensão para além da zona de arrebentação das ondas na costa. Essas correntes de retorno podem ou não representar feições temporárias, geradas a partir do encontro de correntes de deriva litorânea com sentido de propagação opostas, ou pelo desvio de uma dessas correntes pelas irregularidades do fundo marinho. Portanto, com respeito à efetividade e periodicidade deste evento, a falta de levantamentos mais sistematizados, não permite precisar o fenômeno. Entretanto, um deslocamento local das curvas batimétricas, no rumo do mar aberto, em segmento do litoral que apresenta um padrão batimétrico de curvas retilíneas e paralelas entre si, é um forte indício da ocorrência periódica do fenômeno (Tessler, 1988). 


\subsubsection{A distribuição dos sedimentos da atual superfície de fundo}

Durante a década de 70 levantamentos realizados pelo Projeto REMAC (Reconhecimento Global da Margem Continental Brasileira), possibilitaram a confecção de um mapeamento textural dos sedimentos quaternários que recobrem a margem continental brasileira. Este mapeamento apresentado na escala de 1:3.500.000, indicava a plataforma continental situada ao sul do alinhamento Vitória-Trindade como constituída, predominantemente, de sedimentos terrígenos, formados por areias e lamas de natureza quartzosa, com zonas de concentração carbonática situada a profundidades superiores a 100 metros.

Corrêa (1979), reinterpretando as informações sedimentológicas do material do Projeto REMAC, apresentou para a plataforma continental compreendida entre os estados de São Paulo e Santa Catarina, um mapeamento de maior detalhe, caracterizando esta plataforma como uma zona de sedimentação terrígena moderna, progradando sobre uma superfície de areias relíquias quartzosas e biodetríticas (Figura 14).

Neste estudo, a plataforma continental é subdividida em três zonas distintas: fácies arenosa, fácies areno-síltico-argilosa e fácies lamosa.

A plataforma interna exibe textura arenosa, onde predominam areias quartzosas apresentando em algumas áreas cascalho biodetrítico. A fácies arenosa comporta subdivisões em sub-fácies de areia quartzosa; areia quartzosa com biodetritos; areia quartzosa com biodetritos e lama e areia e cascalho biodetrítico, sendo todas as sub-fácies compostas de areias de média a muito fina, predominantemente composta de quartzo. Em alguns casos ocorrem fragmentos mais grossos de calcários biodetríticos e também lamas.

Na plataforma média a textura síltico-argilosa é predominante, secundada por pequenas áreas areno-síltico-argilosas. A plataforma externa apresenta uma textura arenosa composta por areias biodetríticas e cascalhos.

Segundo Corrêa (1979), a presença de carbonato biodetrítico nos sedimentos apresenta uma variação entre $5 \%$, na plataforma interna, até valores 
de $25 \%$ nas plataformas média e externa. Localmente, o teor de carbonato biodetrítico nos sedimentos pode atingir valores ao redor de $50 \%$.

$\mathrm{O}$ atlas sedimentológico da plataforma continental do Estado de São Paulo, elaborado pela área de Oceanografia Geológica do Instituto Oceanográfico da USP, a partir de um banco de dados sedimentológicos institucional, indica a plataforma continental sul paulista como essencialmente terrígena, constituída, em grande parte, por retrabalhamento de sedimentos arenosos regressivos.

Os mapeamentos sedimentológicos, de acordo com o padrão textural dos sedimentos de Shepard (Figura 15), ou de Larsonneur (Figura 16), evidenciam o predomínio das texturas areia na plataforma interna até aproximadamente a isóbata de 50 metros. Em ambos os mapas, é possível identificar manchas de sedimentos mais finos (areia síltica, segundo a classificação de Shepard e lama terrígena, segundo a classificação de Larsonneur), nas proximidades da foz do Rio Ribeira de Iguape. Estas áreas poderiam significar a resposta à deposição parcial dos sedimentos em suspensão do Rio Ribeira de Iguape, causada pela floculação de parte desta carga, ou também, a resposta sedimentar às correntes de deriva litorânea, de sentidos de propagação opostos que, no seu mecanismo de retorno, em direção ao mar aberto, retiram da zona de arrebentação das ondas os sedimentos em suspensão no sistema, possibilitando, ao menos em parte, a deposição de sedimentos mais finos em área de menor energia.

Nas plataformas média e externa, até as proximidades da quebra da plataforma ( 160 metros), predominam misturas de sedimentos de textura fina (siltes e argilas), em faixas alongadas, aproximadamente paralelas às isóbatas e à linha de costa atual, margeadas por sedimentos lamosos com maior teor de areias, que se estende em direção ao talude superior.

A composição mineralógica dos atuais sedimentos de fundo apresenta o predomínio de quartzo nos termos arenosos e de montmorilonita nas texturas lamosas. 


\section{COLETA E PREPARAÇÃO DOS TESTEMUNHOS}

Um conjunto de 13 (treze) testemunhos rasos, coletados a bordo do Navio Oceanográfico "Prof. W. Besnard", entre os meses de dezembro de 1997 e janeiro de 1998, no âmbito do projeto REVIZEE (Recursos Vivos na Zona Econômica Exclusiva. Programa de Geologia e Bentos/Score Sul. Ministério do Meio Ambiente e da Amazônia Legal), constitui o universo de análise para o estudo da taxa de sedimentação na plataforma continental sul do Estado de São Paulo (Tabela 1).

Os testemunhos foram obtidos através da utilização de um "box corer" com penetração máxima de 0,60 metro.

As coletas foram orientadas segundo duas radiais tendo, uma cerca de 130 $\mathrm{km}$ de extensão e orientação no rumo $118^{\circ}$ (SE) e, a segunda, orientada segundo o rumo $50^{\circ}(\mathrm{NE})$, disposta ao longo da isóbata de 100 metros (Figura 1).

Os testemunhos na primeira radial foram coletados entre as isóbatas de $50 \mathrm{~m}$ e $268 \mathrm{~m}$, segundo os sub-compartimentos fisiográficos identificados na área de estudo (plataforma interna, média e externa - Zembruscki,1979), e, principalmente, objetivando amostrar todas as diferentes fácies texturais, da superfície de fundo, identificadas no mapa textural do Instituto Oceanográfico (no prelo, Figura 16).

A radial NE foi estabelecida ao longo da isóbata de $100 \mathrm{~m}$, no limite aproximado entre os domínios das fácies arenosas da plataforma interna e média, e o domínio das fácies lamosas da plataforma média a externa. Esta radial objetiva também a compreensão do comportamento sedimentar dos sedimentos dispostos a SE e NE, da área de estudo, com vistas a identificar uma possível contribuição atual de sedimentos continentais, e o sentido preferencial do transporte desses sedimentos.

As seqüências sedimentares, obtidas pela amostragem com "box-corer", foram descritas e fotografadas a bordo do Navio Oceanográfico. Após estes procedimentos as seqüências foram preservadas através da cravação de tubos de PVC, sendo imediatamente congelados. 
Em razão da necessidade de obtenção de um volume mínimo de sedimento para as análises pretendidas, os testemunhos, com diâmetro de 3 polegadas, foram seccionados, ainda congelados, em intervalos mínimos de $2 \mathrm{~cm}$, que correspondem a amostras contendo entre 40 e 50 gramas de sedimento seco, dependendo da variação dos teores de areia e lama presentes nas amostras. Este procedimento só foi possível de ser adotado face à extrema homogeneidade textural observada nas descrições de bordo.

Desta forma, após o fatiamento, as amostras foram pesadas e submetidas a liofiliozação e novamente pesadas para a obtenção do teor de umidade.

\subsection{Descrição geral dos testemunhos ( "box corer" )}

Os testemunhos coletados foram descritos a bordo, procedimento necessário não somente para futuras definições com relação aos tipos de ensaios a que foram submetidos os testemunhos, mas principalmente, para a identificação de macro estruturas sedimentares visíveis, e da cor apresentada pela seqüência sedimentar amostrada. Sedimentos marinhos, em especial as seqüências lamosas, ricas em matéria orgânica, sofrem pronunciado e rápido processo de mascaramento, por oxidação, da coloração original dos sedimentos.

\section{Testemunho 6651:}

Areia fina com lama. Estrutura maciça apresentando a camada superior $(<5$ $\mathrm{cm}$ ), mais oxidada em relação ao restante do testemunho. Pequenos fragmentos carbonáticos finamente subdivididos, distribuídos ao longo de todo o testemunho. Cor: Topo 5 Y $4 / 2$ e base $10 Y$ 4/2.

Testemunho 6652:

Areia fina com lama, sem estruturação visível (maciça) apresentando a camada superior levemente oxidada. Presença de pequenos fragmentos biodetríticos de dimensões milimétricas. Cor 5GY 4/1. 
Testemunho 6653:

Primeiros 3 centímetros apresentando lama arenosa (areia fina a muito fina), oxidada de cor 7.5 Y 4/2. Restante do testemunho apresentando lama maciça, sem estruturas sedimentares visíveis, de cor 5GY 4/1.

\section{Testemunho 6654:}

Lama fluida, com areia fina. Estrutura maciça sem a presença visível de carbonato biodetrítico. Cor 5GY 4/1.

\section{Testemunho 6655:}

Lama maciça com a ocorrência de restos de ofiuróides até cerca de $30 \mathrm{~cm}$ de profundidade. Camada superior (primeiros $2 \mathrm{~cm}$ ) mais oxidada, com baixos teores de areia e cascalho biodetrítico. $\mathrm{Na}$ base, os sedimentos apresentam-se mais compactados. Cor $5 \mathrm{GY} 4 / 1$.

\section{Testemunho 6657:}

Areia lamosa com a presença de areia grossa e carbonato biodetrítico nos primeiros $4 \mathrm{~cm}$ do testemunho. Cor $7.5 \mathrm{Y} 4 / 2$.

De 4 a $25 \mathrm{~cm}$ areia lamosa com a presença de fragmentos biodetríticos subcentimétricos (moluscos). Cor 5GY 4/1.

Testemunho 6658:

Areia fina com pouca lama e cascalho biodetrítico sub-centimétrico a centimétrico. Estrutura maciça. Cor 10Y 4/2.

\section{Testemunho 6678:}

Nível superior $(0-5 \mathrm{~cm})$ composto por cascalho biodetrítico com pouca lama, de coloração marrom. Presença de um contato brusco e irregular entre o topo e uma camada constituída por uma lama, com pouco cascalho biodetrítico, de coloração cinza esverdeada. Lateralmente foi observada a existência de um espaço, entre o testemunho e a parede do tubo de coleta, preenchido por material 
biodetrítico similar ao material presente na porção de topo da seqüência. Estrutura de sobrecarga (heterolítica) presente entre 14 e $16 \mathrm{~cm}$ de profundidade.

Testemunho 6683:

Lama argilosa plástica e maciça, de cor cinza esverdeada, contando com a presença de fragmentos milimétricos de biodetritos dispersos ao longo de toda a seqüência sedimentar amostrada.

Testemunho 6692:

Lama maciça. Cor 5GY 4/1 (cinza escuro).

Testemunho 6696:

Lama maciça. Cor 5GY 4/1 (cinza escuro).

Testemunho 6700:

Lama maciça. Cor 5GY 4/1 (cinza escuro).

Testemunho 6704:

Lama maciça. Cor 5GY 4/1 (cinza escuro). 


\section{CARACTERIZAÇÃO TEXTURAL E COMPOSICIONAL DOS TESTEMUNHOS}

A caracterização textural e composicional dos sedimentos obtidos a partir das testemunhagens, foi obtida a partir da execução dos ensaios de caracterização do conteúdo em areia e lama, dos teores em carbonato biodetrítico $\left(\mathrm{CaCO}_{3}\right)$, carbono orgânico e nitrogênio e enxofre totais, e dos teores totais dos elementos metálicos $\mathrm{Pb}$, Cu e $\mathrm{Zn}$.

\subsection{Metodologias de análise}

As determinações das variações dos teores de areia e lama, ao longo dos treze testemunhos, foram realizadas por peneiramento úmido, a partir de alíquotas das amostras referentes aos intervalos amostrais considerados para cada testemunho. O peneiramento das alíquotas pré-pesadas, da qual já havia sido eliminado o carbonato de cálcio, foi efetuado em uma peneira de malha de 0,062 $\mathrm{mm}$. A massa retida corresponde à quantidade de areia das amostras, enquanto que a diferença, em peso, entre a amostra total e o peso da fração arenosa correspondeu ao peso da fração lamosa. Os teores calculados consideraram como $100 \%$ a somatória das porcentagens das frações areia e lama (sedimentos terrígenos) e da porcentagem do $\mathrm{CaCO}_{3}$.

As amostras utilizadas para as análises dos teores de carbonato biodetrítico foram as mesmas utilizadas para as análises texturais. Por diferença em peso das amostras pré e pós-tratadas com ácido clorídrico $(\mathrm{HCl} 10 \%)$, foram calculados os teores da fração carbonática biodetrítica de cada amostra obtida do fatiamento dos testemunhos.

As análises do conteúdo em carbono orgânico e nitrogênio e enxofre totais foram executadas em um analisador LECO CNS 2000, pertencente ao laboratório de Geoquímica do Instituto Oceanográfico da USP. Os procedimentos analíticos para obtenção dos teores dos elementos têm início com a pesagem do material seco e o ataque ácido com solução de ácido clorídrico diluído a $10 \%$, até a completa remoção do conteúdo de carbonato biodetrítico. Após o ataque ácido o sedimento é liofilizado e colocado no analisador que, por meio de combustão gera os gases $\mathrm{CO}_{2}$ e $\mathrm{SO}_{2}$ que são analisados através de células de infravermelho, 
sendo o gás $\mathrm{N}_{2}$ medido através de um sensor de termocondutividade. Antes das análises das amostras foi executada a correção das curvas de calibração como descrito em Mahiques (1998).

As análises químicas de cobre, chumbo e zinco foram executadas pela empresa Actilab, no Canadá, em alíquotas das amostras totais obtidas a partir do seccionamento dos testemunhos. As amostras foram digeridas com solução de Água Régia ( $\left.\mathrm{HCL}+\mathrm{HNO}_{3}, 3: 1\right)$, que produz uma digestão total, tendo sido analisadas por espectrometria.

\subsection{Análise dos resultados}

\subsubsection{Teores de areia e lama}

Os resultados obtidos para as variações dos teores dos sedimentos terrígenos ao longo de cada um dos testemunhos analisados apresentaram uma grande homogeneidade de valores (Tabela 2 e Figura 17).

Os testemunhos $6658,6657,6655$ e 6654 coletados na plataforma interna e plataforma média, contêm, ao longo da coluna, teores de sedimentos terrígenos variando entre um valor mínimo de $69,6 \%$, no intervalo de 6 a $10 \mathrm{~cm}$ do testemunho 6658 , a um valor máximo de $82,4 \%$, no topo do testemunho 6657 . De acordo com a classificação de Larsonneur (1977, apud Dias, 1996), estes sedimentos podem ser classificados como sedimentos litoclásticos. Porém, uma análise das variações dos teores de terrígenos, consideradas separadamente as frações areia e lama, ao longo das colunas sedimentares evidenciam que enquanto que para os testemunhos 6658 e 6657, os altos teores de terrígenos são devidos à predominância da fração areia, para os demais 6655 e 6654, este predomínio é devido as maiores concentrações da fração lama.

No testemunho 6658 os teores de areia variaram entre $63,2 \%$ e $72,0 \%$, com porcentagens de lama inferiores a $8,0 \%$. O mesmo pode ser observado para o testemunho 6657 , onde os teores de areia variam entre $57,7 \%$ e $66,1 \%$, enquanto os teores de lama, porcentualmente superiores aos do testemunho 6658, variaram entre $12,7 \%$ e $20,9 \%$. 
Nos testemunhos 6654 e 6655 as concentrações observadas são distintas com os teores de lama, para 6654 , variando entre um mínimo de $39,8 \%$ e um máximo de $55,6 \%$, e para 6655 variando entre $53,8 \%$ e $61,4 \%$.

Para os testemunhos coletados a partir da plataforma externa e no talude superior $(6653,6652$ e 6651), os teores de sedimentos terrígenos apresentam comportamento diferenciado. Os testemunhos coletados a $145 \mathrm{~m}$ de profundidade (6653), e o coletado a 206 metros (6652), contém teores de sedimentos terrígenos próximos a $50 \%$ (6652), ou abaixo deste valor (6653).

O maior teor de sedimentos terrígenos, no testemunho 6652 , foi obtido em suas camadas de topo $(0-4 \mathrm{~cm}), 51,1 \%$, e o menor $(46,7 \%)$ no nível de 14 a $16 \mathrm{~cm}$. O teor máximo do testemunho $6653(46,1 \%)$, também foi obtido nas seqüências de topo, enquanto o menor valor, no intervalo 12 a $14 \mathrm{~cm}(34,2 \%)$. Os sedimentos que compõem estes testemunhos, de acordo com a classificação de Larsonneur (1977, apud Dias, 1996), são classificados como biolitoclásticos.

O testemunho 6651 , coletado no talude superior a $268 \mathrm{~m}$ de profundidade, apresenta altos valores de sedimentos terrígenos ao longo da coluna sedimentar amostrada, com contribuições muito similares das frações areia e lama. Os valores dos teores de terrígenos variaram entre $69,3 \%$ e $73,7 \%$, com a fração areia contribuindo com teores compreendidos entre $34,1 \%$ e $43,9 \%$, enquanto a fração lama apresentou um valor mínimo de $26,8 \%$ e um máximo de $36,9 \%$ (sedimentos litoclásticos).

Analisando-se a variação dos teores de terrígenos, ao longo do perfíl transversal à costa, é possível observar que, nas plataformas interna e média, que engloba os testemunhos $6654,6655,6657$ e 6658 , estão presentes os mais altos valores médios. Esta faixa de sedimentos litoclásticos apresenta tendências diversas entre as frações areia e lama. Os teores de areia decrescem entre as regiões mais rasas e a plataforma média e, conseqüentemente, a este decréscimo corresponde um aumento similar dos teores da fração lama.

Uma comparação destas tendências com os mapas texturais, elaborados pelo Instituto Oceanográfico (no prelo, Figuras 15 e 16), evidencia uma persistência dos ambientes de sedimentação, e com os níveis de energia 
deposicional, no decorrer de todo o intervalo deposicional amostrado e, principalmente, com a dinâmica sedimentar atual das plataformas interna e média.

Furtado \& Mahiques (1990), aplicando a análise de superfície de tendência em dados sedimentológicos e associando-os a informações sobre a circulação da plataforma continental interna norte paulista, concluem que o fundo é constituído por areias finas e muito finas, com características de sedimentos palimpsestos. Os autores ainda indicam que a contribuição continental atual é restrita às proximidades das fontes costeiras, nas enseadas e desembocaduras fluviais, sendo que o material pelítico, transportado em suspensão, pode atingir a plataforma na altura da isóbata de 50 metros, pela saída das águas costeiras durante o verão.

Os testemunhos coletados ao longo do perfil aproximadamente paralelo à atual linha de costa (NE-SW), ao longo da isóbata de 100 metros, apresentam teores diferenciados de sedimentos terrígenos nas áreas extremas do perfil.

Os quatro testemunhos coletados mais a SW da área $(6692,6696,6700 \mathrm{e}$ 6704), apresentam teores de sedimentos terrígenos acima de $75 \%$, sendo a contribuição da fração areia insignificante, comparativamente aos teores da fração lama.

O testemunho 6683 contém, ao longo da coluna, teores de sedimentos terrígenos variando entre um valor mínimo de $67,26 \%$, no intervalo de 06 a $08 \mathrm{~cm}$ de profundidade, a um valor máximo de $72,04 \%$, entre as profundidades de 28 a $30 \mathrm{~cm}$. De acordo com a classificação de Larsonneur (1977, apud Dias, 1996), estes sedimentos podem ser classificados como sedimentos litoclásticos. Porém, uma análise das variações dos teores de terrígenos, consideradas separadamente as frações areia e lama, evidencia que os altos teores são devidos à predominância de maiores concentrações da fração lama ( 63 - 70\%), sendo a pequena contribuição de sedimentos da fração areia corresponde a material de granulação areia muito fina a fina $(0.125$ a $0.062 \mathrm{~mm})$.

Para o testemunho 6678 os teores obtidos de sedimentos terrígenos variaram de um mínimo de cerca de $30 \%$, no intervalo de 02 a $04 \mathrm{~cm}$, para um valor máximo de $46,8 \%$ entre 14 e $16 \mathrm{~cm}$ de profundidade, bastante inferiores aos 
obtidos para o testemunho 6683. Considerada apenas a fração lama verifica-se, também, uma diminuição significativa da contribuição dessa fração granulométrica, com teores oscilando entre um mínimo de 19,16\% e um máximo de $34,4 \%$, no intervalo de 14 a $16 \mathrm{~cm}$, com um valor médio, ao longo de toda a seqüência, ao redor de $24 \%$, associada a um pequeno incremento da contribuição da fração areia também constituída de material de granulação areia muito fina a fina.

Os resultados destes dois testemunhos quando comparados aos obtidos para os testemunhos coletados ao longo do perfil aproximadamente paralelo à atual linha de costa (NE - SW), ao longo da isóbata de 100 metros, apresentam uma diminuição das concentrações de sedimentos terrígenos no sentido NE.

Esta tendência indicativa de uma diminuição dos teores de terrígenos é evidenciada pela presença de teores de terrígenos superiores a $75 \%$, na porção mais a SE/SW da área, com diminuta contribuição da fração areia, para teores não superiores a $47 \%$, com contribuição mais significativa de termos arenosos finos a muito finos.

Esta transição ocorre significativamente na região localizada entre os testemunhos 6683 e 6678, pois as similaridades texturais e composicionais da coluna sedimentar do testemunho 6683 , com as observadas para outros quatro testemunhos coletados mais a SE/SW, na isóbata de 100 metros, indicam um prolongamento para NE da contínua faixa de sedimentos finos depositados na plataforma média, sob condições hidrodinâmicas similares. Estas características deposicionais têm sido persistentes ao longo de todo o período deposicional deste grupo de seqüências sedimentares analisadas na plataforma média, ao sul da área de estudo.

Este perfil, quando comparado com o perfil transversal à costa, evidencia a existência de uma transição entre domínios sedimentares, e hidrodinâmicos, distintos, nas proximidades da isóbata de 100 metros, no limite aproximado entre as plataformas média e externa de Zembruscki (1979). 


\subsubsection{Teores de Carbonato biodetrítico}

Os teores obtidos para os testemunhos da plataforma interna e média apresentam valores médios oscilando ao redor de 20\% (Tabela 2 e Figura 17).

O teor de carbonato biodetrítico obtido no testemunho $6658(30,4 \%)$, entre 6 e $10 \mathrm{~cm}$ de profundidade, representa o maior valor entre todos os níveis analisados, considerados todos os testemunhos coletados entre as isóbatas de 50 e 90 metros. O menor teor $(17,6 \%)$ representa o sedimento do topo do testemunho 6657 , o que denota a homogeneidade da distribuição dos teores de carbonato biodetrítico, ao longo dos testemunhos da plataforma interna a média.

Nos dois testemunhos da plataforma externa e borda do talude (6653 e 6652) predominam as fácies biolitoclásticas, com teores de carbonato de cálcio superiores a $50 \%$, atingindo valores de até $65,8 \%$, no nível de 12 a $14 \mathrm{~cm}$ do tsetemunho obtido a 145 metros de profundidade (6653).

$A$ área compreendida entre a plataforma externa e a borda do talude marca o domínio dos sedimentos bioclásticos, uma vez que, no talude superior (6651), voltam a predominar os sedimentos terrígenos, com concentrações de carbonato biodetrítico entre 25 e $30 \%$

De acordo com a nota explicativa do Atlas Sedimentológico (Instituto Oceanográfico, no prelo), as zonas de concentração de termos carbonáticos, na plataforma continental paulista, situam-se além da isóbata de 100 metros, podendo tanto ser correlacionadas a materiais pretéritos ("beach rocks"), quanto a bioconstruções atuais de algas e corais (Valdenir Veronese Furtado, comunicação pessoal).

Nos testemunhos coletados ao longo da isóbata de 100 metros, (6692, 6696,6700 e 6704) os teores de carbonato biodetrítico são bastante regulares, com teor médio ao redor de $20 \%$, variando entre um máximo de $23,4 \%$, no intervalo $2-4 \mathrm{~cm}$ do testemunho 6696 , e um valor mínimo também no intervalo de 2-4cm, do testemunho 6692.

No testemunho 6683 o teor de carbonato biodetrítico encontrado entre 40 e $46 \mathrm{~cm}$ de profundidade $(27,54 \%)$ representa o menor valor obtido, mas já superior 
ao mais alto valor obtido para os testemunhos coletados a SE/SW, sendo o teor de $32,73 \%$ (06 a 08cm), o valor mais elevado.

Para o testemunho 6678 os teores obtidos são muito mais elevados, tendo sido obtido o menor teor da coluna amostrada na profundidade de 14 a $16 \mathrm{~cm}$ $(53,20 \%)$, atingindo um valor máximo de $70,65 \%$ na seqüência de topo entre $02 \mathrm{e}$ $04 \mathrm{~cm}$, caracterizando este testemunho como sendo composto de sedimentos biolitoclásticos à semelhança das características dos testemunhos analisados nas áreas da plataforma externa e borda do talude (testemunhos 6652 e 6653).

A ocorrência de seqüências sedimentares bioclásticas, nas proximidades da isóbata de 100 metros, quando comparada aos teores dos sedimentos coletados nesta isóbata mais a SE/SW da área, onde os valores médios oscilam ao redor de $20 \%$, indica uma mudança no padrão de sedimentação, dos termos terrígenos para predomínio de sedimentos bioclásticos.

A área de influência do testemunho 6683 , onde o teor médio de carbonato biodetrítico $(28,8 \%)$ é superior à média da área de domínio dos terrígenos localizada mais a SE/SW (20\%), e cerca de metade do valor médio obtido para a seqüência sedimentar coletada mais a NE (amostra 6678), indica claramente a ocorrência de uma transição gradual, na plataforma média ao redor da isóbata de 100 metros, entre o predomínio de facies de sedimentos litoclásticos para fácies bioclásticas.

\subsubsection{Teores de carbono orgânico, nitrogênio e enxofre total.}

O carbono e o nitrogênio são dois dos elementos mais importantes na estrutura da matéria orgânica dos seres vivos. O carbono está presente em todas as moléculas orgânicas, ao passo que o nitrogênio é elemento fundamental na estrutura das proteínas (Mahiques, 1998).

Em sedimentos marinhos o teor de carbono orgânico tem sido diretamente correlacionado à produtividade de águas superficiais (Stein, 1991, apud Mahiques, 1998).

O enxofre é um elemento normalmente encontrado na forma de sulfetos nos fundos marinhos. Sua presença, na forma de sulfeto de ferro pode ocorrer 
como mineral detrítico ou como autigênico. Em ambos os casos, a presença de sulfetos em sedimentos marinhos é indicativa de condições anóxicas de deposição.

A tabela 2 apresenta os resultados das análises executadas para o carbono orgânico, nitrogênio e enxofre totais, bem como dos valores obtidos para a relação $\mathrm{C} / \mathrm{N}$.

Uma avaliação da variação dos teores de carbono orgânico e nitrogênio total, nos testemunhos analisados, indicam de maneira geral uma tendência de decréscimo dos teores do topo, no sentido da base do pacote sedimentar (Figura 17). Os teores de carbono variaram entre um mínimo de $2,4562 \mathrm{mg} / \mathrm{g}$, até um valor máximo de $18,8712 \mathrm{mg} / \mathrm{g}$, no intervalo de 00 a $02 \mathrm{~cm}$ de profundidade, do testemunho 6683.

A variação do nitrogênio total apresentou um valor mínimo de 0,1972 mg/g, no testemunho 6651 , entre 16 e $18 \mathrm{~cm}$ de profundidade, e um valor máximo de $2,0655 \mathrm{mg} / \mathrm{m}$, no sedimento do topo do testemunho $6683(02-04 \mathrm{~cm})$.

O comportamento do enxofre, ao longo dos testemunhos, se apresenta oposto ao dos outros dois elementos, com uma tendência a aumento dos teores do topo no sentido da base dos testemunhos. A maior concentração obtida corresponde ao horizonte 40 a $42 \mathrm{~cm}$ do testemunho $6683(3,9578 \mathrm{mg} / \mathrm{g})$ e, a menor, ao horizonte 10 a $12 \mathrm{~cm}$, do testemunho 6653 , com um valor de 0,1067 $\mathrm{mg} / \mathrm{g}$ de sedimento seco.

Com relação à distribuição espacial destes três elementos verifica-se que, tanto o carbono orgânico como o nitrogênio total apresenta uma tendência de crescimento dos teores médios, no sentido da plataforma interna para a plataforma média e, a partir desta área, de diminuição das concentrações para as regiões da plataforma externa e talude superior.

Esta tendência geral também pode ser verificada para o enxofre, no sentido da costa para o oceano.

Ao longo do perfil longitudinal à costa, sobre a isóbata de 100 metros, os teores obtidos são mais homogêneos, observando-se ligeiras tendências de 
aumentos dos teores de carbono orgânico, nitrogênio e enxofre totais, no sentido dos extremos SE/SW e NE do perfil, entre os testemunhos 6692 e 6683.

No testemunho 6678 , coletado a NE do 6683, verifica-se uma alteração da tendência de crescimento dos teores. Nesta região, os teores de carbono orgânico, nitrogênio e enxofre total são da mesma ordem de grandeza dos obtidos para as plataformas interna e externa correspondendo à metade dos teores obtidos para a fácies lamosa amostrados ao longo da isóbata de 100 metros. Esta coluna sedimentar apresenta, também, uma tendência à diminuição dos teores de carbono orgânico e nitrogênio total, no sentido do topo para a base, dos testemunhos, e uma tendência de decréscimo dos teores de enxofre total, do topo no sentido da base do testemunho.

Comparados os teores obtidos nas seqüências de topo dos testemunhos, com o mapeamento da distribuição espacial do carbono orgânico, nitrogênio e enxofre total, da plataforma do Estado de São Paulo, apresentado por Mahiques (1998), verifica-se uma perfeita concordância entre as ordens de grandeza obtidas neste trabalho, com os valores expressos no estudo de Mahiques (op. cit.), bem como com as tendências de distribuição espacial apresentadas (Figura 18).

Com relação a razão carbono/nitrogênio sabe-se que devido a sua natureza distinta, materiais orgânicos de origem vegetal e animal exibem diferentes valores da razão $\mathrm{C} / \mathrm{N}$. Valores próximos de 20 (em massa) são indicativos de matéria orgânica de origem predominantemente continental (plantas superiores). Por outro lado, valores de razão $\mathrm{C} / \mathrm{N}$ próximos de 6 são indicadores de matéria orgânica de origem predominantemente pelágica. Valores intermediários refletem contribuições mistas.

As razões $\mathrm{C} / \mathrm{N}$ obtidas indicam valores médios inferiores a 11 para toda a região compreendida entre a plataforma média e o talude superior, e uma tendência do crescimento desta razão na plataforma interna, no sentido do oceano para o continente (Figura 19).

Já a coluna sedimentar do testemunho 6678 , a NE do perfil longitudinal à costa, varia entre um mínimo de 11,56 (00-02cm), e um valor máximo de 13,47 (06-08 cm de profundidade), correlacionável com as razões obtidas para a 
seqüência sedimentar amostrada na plataforma média ( testemunho 6657), e mais elevada que o valor médio, bastante homogêneo, obtido dos sedimentos coletados dos testemunhos do perfil de 100 metros.

Comparando-se estes resultados com o mapa de distribuição da razão $\mathrm{C} / \mathrm{N}$, elaborado por Mahiques (1998), para a plataforma paulista, verifica-se a existência de um núcleo de de contribuição continental localizado na região a SE da Ilha Comprida. Segundo Mahiques (op.cit.), os altos valores da razão $\mathrm{C} / \mathrm{N}$, na área, podem estar relacionados aos baixos teores de nitrogênio, o que levaria a ocorrência dos altos valores da razão.

Desta forma, a matéria orgânica depositada seria, predominantemente, de origem pelágica, muito embora existam condições da exportação de matéria orgânica de origem continental em direção a plataforma externa, especialmente nas proximidades das desembocaduras do Rio Ribeira de Iguape, da desembocadura de Cananéia e da Baía de Paranaguá.

Os dados da razão $\mathrm{C} / \mathrm{N}$ também indicam ocorrer uma transição das fontes de contribuição preferencial de sedimentos orgânicos de origem vegetal e animal, na porção mais a NE da área, entre os testemunhos 6683 e 6678, sendo maior a contribuição de materiais orgânicos de origem animal na região a NE do testemunho 6683, predominando os de origem pelágica a SW/SE deste testemunho.

\subsubsection{Teores totais dos elementos Chumbo, Cobre e Zinco}

Os teores obtidos para todo o conjunto de amostras apresentam intervalos de variação distintos para os três elementos considerados (Tabela 2 - Figura 17).

Apenas para o elemento cobre os teores obtidos no testemunho 6652, nas profundidades entre 16 e $28 \mathrm{~cm}$, o valor é inferior ao limite de detecção do método $(-1)$. Para todas as demais seqüências analisadas os teores do cobre variaram entre um mínimo de 1ppm; nos testemunhos 6651, 6652 e 6653; a 27 ppm nos testemunhos coletados ao longo da isóbata de 100 metros.

Com relação às variações dos teores de cobre, ao longo das secções amostradas, pode-se observar um pequeno intervalo de oscilação dos teores 
obtidos, em relação a um valor médio calculado para cada testemunho. Um único testemunho, 6655, apresenta um forte gradiente entre os teores de cobre obtidos para a seqüência de topo (de 0 a $8 \mathrm{~cm}, 6-7 \mathrm{ppm}$ ), para o restante da seqüência que apresenta valores superiores a $15 \mathrm{ppm}$.

Quando analisados os resultados obtidos pelos compartimentos geomorfológicos (Zembruscki, 1979), verifica-se que os testemunhos coletados na faixa de transição entre a plataforma interna e a plataforma média (6658 e 6657), possuem teores de cobre variando entre 6 e $10 \mathrm{ppm}$, valores pouco superiores aos obtidos para os testemunhos da plataforma média (6654 e 6655) com intervalo de variação entre 4 e 8 ppm.

A seqüência de base do testemunho $6655(08-40 \mathrm{~cm})$, coletado na profundidade de 80 metros, embora não apresente diferenças texturais com relação à seqüência de topo, contém teores muito superiores de cobre, em relação aos sedimentos de topo (fator de 2 a 3), bem como as ordens de grandeza dos resultados de todos os teores de cobre, dos testemunhos coletados nas plataformas interna a média.

Em princípio, esta variação poderia ser indicativa de uma alteração no volume de aporte do elemento, ou da fase orgânica ou inorgânica na qual o cobre está sorvido, ou a uma mudança do regime hidrodinâmico da área, no período deposicional da seqüência de topo.

Nas maiores profundidades os testemunhos analisados $(6653,6652$ e 6651) contêm sedimentos com teores de cobre muito próximos do limite de detecção do método, evidenciando a pequena contribuição do elemento, ao longo de todo o processo deposicional, destas seqüências analisadas.

Nos testemunhos coletados ao longo da isóbata de 100 metros (6692, 6696, 6700, 6704 e 6683), pode ser observada uma extrema homogeneidade nos teores de cobre obtidos, variando entre um valor mínimo de $17 \mathrm{ppm}$ e um valor máximo de 27 ppm, ao longo de todas as colunas analisadas (Figura 17).

As ordens de grandeza dos teores obtidos nestes testemunhos é superior a um fator de 3 e 4 vezes, comparativamente aos testemunhos analisados nas demais profundidades, caracterizando-a como a faixa batimétrica preferencial, em 
toda a plataforma continental e talude superior, de deposição dos sedimentos com teores mais elevados de cobre. Porém, o teor médio de cobre, obtido para o testemunho 6683 , representa um fator multiplicativo de 2 , quando comparado ao valor obtido para o testemunho 6678, que apresenta conteúdo similar aos teores médios obtidos para os testemunhos da plataforma interna ( 9,5ppm). Este fato é indicativo de uma diferenciação composicional e geoquímica dos sedimentos amostrados, na isóbata de 100 metros, a NE do testemunho 6683.

Para o elemento chumbo, na transição entre as plataformas interna e média é observada uma variação dos teores entre um mínimo de $2 \mathrm{ppm}$ e um máximo de 13ppm. Já entre as isóbatas de 70 e 100 metros (plataforma média), os teores são mais elevados, oscilando entre 12 e 22ppm sendo que, em direção às maiores profundidades, os teores médios obtidos são da mesma ordem de grandeza dos teores obtidos para a região da plataforma interna.

Na plataforma externa, o elemento chumbo, oscila entre teores mínimos de $4 \mathrm{ppm}$ e máximos de 12ppm, semelhantes ao intervalo de oscilação, 5 a $11 \mathrm{ppm}$, do testemunho coletado no talude superior (6651), sendo que apenas a camada de topo deste testemunho $(0-2 \mathrm{~cm})$, apresenta um valor discrepante com relação ao teor de chumbo (22ppm). Porém, como esta amostra não possui duplicata, e o valor encontrado representa um único intervalo amostral, fica a dúvida com relação ao significado deste valor.

Ao longo do perfil longitudinal à costa, o teor médio obtido, no segmento compreendido entre os testemunhos 6692 e 6683, representa os teores mais elevados de toda a área da plataforma sul paulista.

Os teores para o chumbo apresentam um comportamento bastante diferenciado entre os dois últimos testemunhos analisados e todos os demais testemunhos coletados no perfil aproximadamente paralelo à atual linha de costa (100m).

Ao longo da seqüência sedimentar amostrada no testemunho 6683 é possível diferenciar intervalos distintos de comportamento para o elemento chumbo. À exceção da camada de topo $(0-4 \mathrm{~cm})$, que apresenta valores entre 22 e $36 \mathrm{ppm}$, as demais profundidades apresentaram teores inferiores aos valores 
médios obtidos para todas as seqüências sedimentares coletadas a SE/SW deste testemunho.

Entre 4 e $10 \mathrm{~cm}$ de profundidade os teores oscilam ao redor de um valor médio de 12 ppm, elevando-se novamente para valores ao redor de 20 a 22 ppm, no intervalo entre 10 e $14 \mathrm{~cm}$, quando passam a apresentar, no sentido da base, valores decrescentes atingindo teor mínimo de $4 \mathrm{ppm}$ entre 42 e $46 \mathrm{~cm}$ de profundidade.

Para o testemunho 6678 os teores de chumbo obtidos para toda a coluna sedimentar amostrada, apresentam valores inferiores ao limite de detecção do método de análise ( 2ppm).

Uma análise dos teores médios de chumbo para todos os seis testemunhos coletados no perfil aproximadamente paralelo à atual linha de costa $(6692,6696$, $6700,6704,6683$ e 6678), indica uma pequena tendência de diminuição dos teores para SE/SW, a partir da seqüência de topo do testemunho 6683, e um acentuado decréscimo dos teores para NE.

Uma análise comparativa das ordens de grandeza entre os teores de chumbo dos sedimentos destes testemunhos do perfil paralelo à costa, e o "background" regional dos sedimentos do Vale do Ribeira (16ppm - Moraes, 1997), indica ocorrer, ao longo desta faixa, teores que oscilam entre valores compatíveis com os valores regionais e valores superiores à média regional (41 ppm), consideradas apenas a seqüência de topo do testemunho 6683 e as seqüências sedimentares coletados ao sul deste testemunho.

Para NE os teores obtidos apresentam-se inferiores ao "background" regional, ou mesmo abaixo do limite de detecção do método.

O elemento zinco apresenta, na transição entre a plataforma interna e média, teores variáveis entre um mínimo de 20 e um máximo de $34 \mathrm{ppm}$, e teores entre 45 e 74ppm na faixa compreendida entre as isóbatas de 70 e 100 metros. Em direção às maiores profundidades, os teores médios encontrados são da mesma ordem de grandeza dos teores obtidos para a área da plataforma interna.

No perfil amostrado ao longo da isóbata de 100 metros, o comportamento do elemento zinco se apresenta homogêneo ao longo dos testemunhos e de toda 
a área, oscilando entre um teor mínimo de $57 \mathrm{ppm}$ e um máximo de $85 \mathrm{ppm}$, à exceção da área mais a NE onde, para o testemunho 6678, foram obtidos teores de ordem de grandeza da metade das obtidas para a área mais a SE/SW. Neste testemunho, o elemento zinco apresenta uma variação entre um mínimo de $26 \mathrm{ppm}$ e um máximo de $41 \mathrm{ppm}$, também distribuídos homogeneamente ao longo da seqüência sedimentar amostrada.

Uma análise comparativa das ordens de grandeza, entre os sedimentos da plataforma e o "background" regional dos sedimentos do Vale do Ribeira (Moraes, 1997) indica que, ao longo de todos os compartimentos geomorfológicos estudados, os teores de chumbo encontrados são compatíveis com a média regional (16 ppm). Anomalias positivas, relativas a este valor médio, são observadas apenas nos sedimentos da região da isóbata de 100 metros, cujos teores variam entre valores compatíveis com a média regional (16 ppm) e teores superiores ao dobro deste valor (41 ppm). Este padrão também é observado para os metais cobre e zinco. De acordo com Moraes (1997), o "background" do cobre é de 18 ppm e o do zinco de 47 ppm, enquanto que as variações dos teores médios destes elementos, ao longo da faixa dos 100 metros, também ocorrem entre valores da mesma ordem de grandeza (17 ppm, para o cobre e 59 ppm para o zinco), até valores máximos de 22 ppm para o cobre, e de 86 ppm para o zinco.

Os mais altos valores de chumbo e zinco, obtidos no perfil longitudinal à costa, são da mesma ordem de grandeza do "background" regional estimado para a região das minas desativadas do Alto Vale do Ribeira, de 35 ppm de Pb e 70 ppm de Zn (Corsi ,1999).

Um mapeamento geoquímico regional realizado pela CPRM (Machado, 1985), constitui-se no único conjunto de dados, de escala regional, sobre os níveis de metais contidos nos sedimentos da margem continental brasileira. Muito embora as técnicas de análise executadas por este projeto não permitam uma comparação direta entre seus resultados e os teores, obtidos para a plataforma continental sul paulista, verifica-se que os teores obtidos para o perfil de 100 metros, se apresentam superiores à média regional da plataforma brasileira, cujos 
valores calculados são de 12 ppm para o cobre, 16 ppm para o chumbo (Figura 20).

Diferentemente das observações feitas para o chumbo e o cobre, o teor de zinco mostra concentrações muito baixas para a plataforma paulista, relativamente à média calculada pela CPRM, para toda a plataforma brasileira (149 ppm).

Dornelles et. al. (1998), em um estudo dos teores de metais contidos nos sedimentos da plataforma continental da região de Cabo Frio (RJ), encontraram valores de cobre variando entre 0,8 a $7,7 \mu \mathrm{g} / \mathrm{g}$, entre 1,5 e $22,9 \mu \mathrm{g} / \mathrm{g}$ de chumbo e de 4,2 a $55,3 \mu \mathrm{g} / \mathrm{g}$ de zinco. Estes valores são inferiores às variações de chumbo e cobre, obtidas para a plataforma paulista. Neste estudo os autores também apresentam dados geoquímicos obtidos para a plataforma e talude do Estado do Rio de Janeiro, com valor médio de cobre de 3,3 $\mu \mathrm{g} / \mathrm{g}$, de $6 \mu \mathrm{g} / \mathrm{g}$ de chumbo e de $10,5 \mu \mathrm{g} / \mathrm{g}$ zinco, que são muito inferiores às médias obtidas para a plataforma sul paulista.

Análises de correlação, realizadas preliminarmente entre os teores dos elementos metálicos e os demais parâmetros analisados (porcentagens de areia, lama, $\mathrm{CaCO}_{3}$, carbono orgânico e nitrogênio total), apenas evidenciaram correlações positivas, e significativas, já há muito relatadas pela bibliografia, como entre os metais e teores elevados de lama e os componentes da matéria orgânica.

Análises de agrupamento, executadas para os dados não normalizados dos elementos metálicos (distância Euclidiana), evidenciaram agrupamentos, para os matais cobre e zinco, que separam os testemunhos coletados ao longo da isóbata de 100 metros, dos obtidos para a plataforma interna e média e os da plataforma externa e talude superior.

Para o elemento chumbo o agrupamento obtido individualiza, em um mesmo agrupamento, todos os testemunhos da plataforma média $(6654,6655$, 6692, 6696 e 6700), coletados a SE/SW do testemunho 6704, podendo indicar uma possível existência de uma área de transição na sedimentação atual, ou uma mudança de posição do centro deposicional, entre os extremos do perfil longitudinal à costa. 


\section{DETERMINAÇÃO DA COMPOSIÇÃO ISOTÓPICA (Pb/Pb)}

As séries dos isótopos ${ }^{238} \mathrm{U} \rightarrow{ }^{206} \mathrm{~Pb} ;{ }^{235} \mathrm{U} \rightarrow{ }^{207} \mathrm{~Pb}$ e ${ }^{232} \mathrm{Th} \rightarrow{ }^{208} \mathrm{~Pb}$ apresentam três seqüências de componentes intermediários formados pelo processo de decaimento radioativo. Nenhum, entre todos os componentes intermediários destas três séries de decaimento, é membro de mais de uma série. Além disso, as três séries apresentam, como produtos finais, distintos isótopos de chumbo.

A segregação do chumbo e do urânio, promovida pelo processo de cristalização da galena, faz com que as razões isotópicas do chumbo, neste mineral, sejam preservadas inalteradas a partir daquele momento. Isto ocorre porque o urânio, que eventualmente poderia permanecer no cristal de galena, apresenta-se em baixas concentrações, quando comparado com o do chumbo. Portanto, os produtos, do decaimento deste urânio não seriam capazes de promover alterações significativas nas composições isotópicas do mineral (Moraes, 1997).

Segundo Gulson (1986, apud Moraes, 1997), a base da prospecção geoquímica que utiliza o método de isótopos de chumbo assenta-se no fato de que diferentes tipos de mineralizações apresentam distintas assinaturas isotópicas, e que, estas mineralizações, não sofrem alterações nos diversos estágios de sua evolução metalogenética e dos processos intempéricos superficiais.

\subsection{Metodologia de análise}

Como os sedimentos pretendidos para análise continham carbonato biodetrítico e alto teor de matéria orgânica, dois tratamentos de pré-análise foram necessários objetivando individualizar o chumbo contido na fração terrígena do incorporado nas fases carbonática e orgânica. 
Os pré-tratamentos consistiram em ataques ácidos, sendo o primeiro deles realizado com $\mathrm{HBr}$ (ácido brômico $1 \mathrm{~N} / 3 \mathrm{~N}$ ), que teve o objetivo de dissolver o carbonato biodetrítico. Este primeiro lixiviado, isento de fase carbonática, foi analisado produzindo os resultados designados como $\mathrm{L} 1$.

Um segundo lixiviado (L2), produzido a partir do resíduo de L1, foi aquecido com água régia, em chapa aquecedora, para atacar a matéria orgânica.

$O$ resíduo deste ataque foi transferido para uma bomba de digestão de teflon onde foram adicionados ácido fluorídrico (HF) e ácido nítrico (HNO3), sucessivamente, para dissolver a fase silicática.

Este preparado (bomba) foi encapsulado em uma jaqueta de aço inoxidável e levado a estufa para ser aquecido a $150^{\circ} \mathrm{C}$ por 5 dias.

Esta solução foi evaporada e, ao resíduo foi adcionado $\mathrm{HCl}$, sendo a bomba deixada na estufa para a conversão de fluoretos insolúveis em cloretos solúveis.

Após um período de 12 horas a solução foi evaporada e, ao resíduo, foi adicionado $\mathrm{HBr}(1 \mathrm{~N})$ sendo, então passada em coluna de troca iônica para purificação do $\mathrm{Pb}$.

A solução contendo $\mathrm{Pb}$ foi evaporada e depositada em filamentos de rênio para a determinação das composições isotópicas de $\mathrm{Pb}(206 / 204 ; 207 / 204$ e 208/204), por espectrometria de massa.

\subsection{Análise dos resultados}

Os resultados obtidos para os lixiviados L1 e L2 estão apresentados na tabela 3.

As razões obtidas para os lixiviados L1 e L2 não apresentam grandes diferenças numéricas, estando todo o conjunto de resultados compreendido em um intervalo definido de variação e desvio padrão.

As razões isotópicas, para as quinze amostras analisadas, indicaram valores para a razão 206/204 variando entre um valor máximo de 19,024 e um valor mínimo de 17,813. Para a razão 207/204 os valores variaram entre 15,525 e 17,779, enquanto a razão 208/204 apresenta um valor mínimo de 37,746 e máximo de 40,041. 
Os sedimentos depositados nas plataformas continentais são originários do aporte de diferentes fontes, ao longo do tempo, com distintos históricos de formação e, portanto, com diferentes razões isotópicas. A evolução do pacote sedimentar holocênico da plataforma continental sul paulista está diretamente associada às litologias diversas, do Complexo da Serra do Mar e do Vale do Ribeira, que margeiam esta plataforma, e de fontes diversas que possam ter fornecido sedimentos para a área, ao longo dos eventos holocênicos de oscilação relativa do nível marinho. Portanto, os sedimentos das seqüências sedimentares holocênicas desta plataforma devem representar uma mistura entre chumbo de diversas origens, e a razão isotópica encontrada deverá refletir a média ponderada destas contribuições.

Moraes (1997), baseado nos trabalhos de Tassinari et.al. (1990) e Daitx (1996) definiu os campos de variação das razões isotópicas das principais litologias do Vale do Ribeira, em especial das áreas mineralizadas em chumbo associadas aos jazimentos do tipo Perau e Panelas, drenadas pela bacia do Rio Ribeira de Iguape.

Confrontados os campos de variação das razões isotópicas dos sedimentos e rejeitos das áreas mineralizadas em chumbo do Vale do Ribeira, bem como dos sedimentos das calhas da drenagem Ribeira, e do Sistema costeiro, com as razões obtidas para as seqüências sedimentares holocênicas da plataforma continental sul paulista, obtém-se uma perfeita diferenciação entre os grupos de sedimentos (figura $21 \underline{\mathrm{a}} ; \underline{\mathrm{b}} ; \underline{\mathrm{c}}$ ).

De acordo com Moraes (1997), as razões isotópicas obtidas nas amostras de sedimentos da calha do Rio Ribeira de Iguape e no Sistema Cananéia-Iguape (Sistema Costeiro), mostram que as mesmas se sobrepõem aos intervalos de variação dos depósitos de chumbo do tipo Panelas.

Esta constatação indica que a extensa distribuição e as altas concentrações de chumbo observadas nos sedimentos da calha do Rio Ribeira de Iguape originários, prioritariamente, dos jazimentos tipo Panelas, distantes mais de $300 \mathrm{~km}$ da foz atual Ribeira de Iguape, são transportados em suspensão, na forma de particulados finos, pelo corpo d'água até sua foz, junto ao Sistema costeiro. 
Porém, o campo de variação das razões isotópicas dos sedimentos da plataforma não se sobrepõe às razões dos sedimentos da calha do rio, ou dos jazimentos de chumbo do Vale, mas à da razão obtida para uma amostra do Alto Vale do Ribeira, recolhida na drenagem a montante da cidade de Ribeira (SP), e de todas as minas conhecidas, representativa das contribuições oriundas dos terrenos vulcânicos e sedimentares proterozóicos e de granitóides, de idade Fanerozóica.

Moraes (1997) indica, também, que as amostras de sedimentos coletados ao longo do curso do Rio Ribeira de Iguape apresentam, à medida que se aproximam da foz, composições isotópicas mais "modernas", com um gradativo deslocamento de suas razões isotópicas na direção da amostra coletada a montante da cidade de Ribeira, SP (amostra 1, figura 21무무으). Este comportamento seria resultado do decréscimo da concentração de chumbo ao longo do curso do rio e da entrada de chumbo carreado pelos afluentes que drenam litologias mais "modernas", o que resultaria na diminuição da participação relativa do chumbo advindo das áreas de jazimento.

Os sedimentos da plataforma continental indicam, em sua composição uma participação relativa dos sedimentos originários da calha atual do Rio Ribeira de Iguape, uma vez que as concentrações de chumbo obtidas, especialmente para os testemunhos recolhidos na isóbata de 100 metros, apresentam teores de chumbo, cuja ordem de grandeza (22ppm) é similar ao "background regional" e aos teores dos sedimentos da foz do Rio Ribeira de Iguape (26 $\mu \mathrm{g} / \mathrm{g}$ - Moraes, 1997). 


\section{TAXAS DE SEDIMENTAÇÃO}

\subsection{Métodos de estudo para obtenção de taxas de sedimentação em ambientes marinhos rasos}

Cálculos de valores de taxas de sedimentação holocênica em ambientes marinhos rasos atuais dependem, basicamente, da obtenção de datações absolutas de materiais sedimentares e/ou eventos geológicos, visto serem muito limitadas e imprecisas as possibilidades de utilização, para o Quaternário superior, das técnicas baseadas em datação relativa ou correlação estratigráfica e sismoestratigrafia.

Datações absolutas de eventos geológicos e sedimentos coletados de seqüências sedimentares rasas e, por conseguinte, estudos de taxas de sedimentação em ambientes marinhos rasos têm se constituído em um dos campos de pesquisa em Ciências da Terra, de maior desenvolvimento técnicocientífico ao longo do século XX.

"Desde o fim do século XIX têm sido propostos e acha-se em desenvolvimento vários métodos para determinação de idades absolutas. Atualmente existem mais de 40 métodos radiocronológicos de datação de materiais quaternários" (Suguio, 1999).

As técnicas geocronológicas normalmente empregadas variam quanto a seus alcances (idades mínimas e máximas) e precisão sendo, para o Quaternário, desde dezenas a centenas de milhares de anos.

Dentre todos os métodos o mais difundido como ferramenta nos estudos do Pleistoceno tardio e no Holoceno, é o método isotópico baseado no ${ }^{14} \mathrm{C}$ (Trumbore, 2000).

Nas porções inferiores da estratosfera os nêutrons, produzidos pelo impacto dos átomos de ar com os raios cósmicos combinam-se com os átomos de ${ }^{14} \mathrm{~N}$ originando átomos de ${ }^{14} \mathrm{C}$ (Trumbore, 2000).

Este átomo de ${ }^{14} \mathrm{C}$ combina-se com o oxigênio do ar dando, como resultado, $\mathrm{O} \mathrm{CO}_{2}$ que se distribui pela atmosfera e hidrosfera, sendo absorvido pelos seres vivos através de trocas metabólicas, atingindo o mesmo teor de ${ }^{14} \mathrm{C}$ existente na natureza e que, devido à sua meia vida curta (5730 \pm 40 anos), 
relativamente ao Tempo Geológico, já atingiu ao longo do tempo um teor de equilíbrio entre as quantidades de átomos formados e desintegrados, a taxas conhecidas e fixas.

Cessadas as trocas metabólicas, com a morte dos organismos, inicia-se a desintegração do radiocarbono absorvido pela forma vivente e, através de medidas do teor residual de ${ }^{14} \mathrm{C}$, obtido pela medição da intensidade de emissão dos raios beta emitidos no processo de desintegração, pode-se calcular o tempo decorrido após a morte do organismo.

Medidas de ${ }^{14} \mathrm{C}$, na natureza, foram executadas inicialmente na Universidade de Chicago, por Libby e colaboradores, após o fim da II Guerra Mundial, tendo sido aplicado pela primeira vez como método de datação, radiocarbono, também por Libby em 1955 (Suguio, 1999).

Com o aprimoramento do método (técnica AMS) foi possível de se extrair conteúdos orgânicos, não apenas de elementos fósseis, mas diretamente da matéria orgânica dispersa em seqüências sedimentares rasas de ambientes aquáticos atuais.

A aplicabilidade do método de datação por ${ }^{14} \mathrm{C}$ é limitada por diversos fatores:

a) A variação do ${ }^{14} \mathrm{C}$ no $\mathrm{CO}_{2}$ atmosférico, no passado;

"Supõe-se que tenha prevalecido um estado de equilíbrio entre a taxa total de produção do radiocarbono e o decaimento radioativo. Isto equivale dizer que a radioatividade específica do $\mathrm{CO}_{2}$ atmosférico e biosférico, considerados em equilíbrio, não variou no decorrer do tempo, tendo sido teoricamente constante nos últimos 50.000 anos o que, na prática, sabe-se não ter ocorrido“ (Suguio, 1999).

b) Pela acuidade total da análise do radiocarbono, incluindo a contaminação do nível de base;

"Admite-se que os teores de radiocarbono sejam constantes nos elementos que compõem a atmosfera, a biosfera e a atmosfera. $O$ teor de radiocarbono na superfície terrestre deveria ser uniforme, em escala global, para que todas as amostras tivessem a mesma atividade inicial. Deste modo, em datações de zonas 
palinológicas da Europa foram encontradas idades aparentemente mais velhas de 1000 a 3000 anos".

"Considera-se também que após a morte do ser vivo, da qual se deseja datar os restos fósseis, não tenham ocorrido trocas posteriores entre o carbono da amostra e do meio ambiente. Entretanto podem surgir várias oportunidades de contaminação, o que representa problema muito sério, por infiltração de ácidos orgânicos" (Suguio, 1999);

c) A própria seleção da amostra no campo para a datação.

"A idade radiocarbono derivada de uma amostra é apenas de confiança da própria amostra. Muitas amostras coletadas no campo não permaneceram em um ambiente fechado desde o tempo em que foi agregada ao sedimento ou solo, ou não verdadeiramente representa a idade do evento o qual o investigador deseja reconstituir. Em outros casos como quando um volume de matéria orgânica, no paleossolo ou no sedimento é datado, a idade obtida pode não refletir a idade verdadeira do evento, mas melhor a acumulação do carbono no solo, ou sedimento, por um período de tempo de milhares de anos" (Trumbore,2000).

Por todos estes fatores, o intervalo de aplicabilidade do método de datação baseado no ${ }^{14} \mathrm{C}$ é geralmente estabelecido entre 300 e 55000 anos, sendo que a sua precisão é variável dependendo da escala de calibração utilizada para conversão dos anos ${ }^{14} \mathrm{C}$ em idades relacionadas ao tempo decorrido entre o presente e o passado. Apenas a partir de 1963, o ano de máxima produção de ${ }^{14} \mathrm{C}$, pelos testes nucleares, o conteúdo de ${ }^{14} \mathrm{C}$ das amostras podem ser comparadas com a curva atmosférica do ${ }^{14} \mathrm{C}$. Para períodos anteriores, as calibrações baseiam-se em pressupostos diversos, como os registros calibrados dos anéis de árvores.

Para períodos de tempo curtos, inferiores ao intervalo de precisão do método do radiocarbono, outros métodos, baseados nas séries de desequilíbrio do $U$ e Th, em especial do radionuclídeo ${ }^{210} \mathrm{~Pb}$, e no decaimento radioativo de radionuclídeos artificiais ( $\left.{ }^{137} \mathrm{Cs}\right)$, vêm sendo utilizados.

Os radionuclídeos da série de decaimento do ${ }^{238} \mathrm{U}$ são elementos radioativos naturais e se encontram disseminados no ambiente em quantidades 
traços. ${ }^{226} \mathrm{Ra}\left(\mathrm{t}_{1 / 2}=1622\right.$ anos), um elemento intermediário da série, presente na crosta terrestre, decai para ${ }^{222} \mathrm{Rn}\left(\mathrm{t}_{1 / 2}=3,8\right.$ dias) que, por ser um gás, move-se do local de geração na rocha ou solo para a atmosfera numa taxa média de 42 átomos.min. $\mathrm{cm}^{-2}$ da superfície da Terra. $\mathrm{O}^{222} \mathrm{Rn}$, após sucessivos decaimentos de elementos de meias-vidas curtas, decai para o ${ }^{210} \mathrm{~Pb}$.

${ }^{210} \mathrm{~Pb}\left(\mathrm{t}_{1 / 2}=22,3\right.$ anos $)$ decai por emissão de partículas beta $\left(\mathrm{E}_{\beta}=17 \mathrm{keV}\right) \mathrm{e}$ raios gama $\left(E_{\gamma}=47 \mathrm{keV}\right)$ para ${ }^{210} \mathrm{Bi}\left(\mathrm{t}_{1 / 2}=5,01\right.$ dias, $\left.\mathrm{E}_{\beta}=1,16 \mathrm{MeV}\right)$, que origina $\mathrm{o}$ ${ }^{210} \mathrm{Po}\left(\mathrm{t}_{1 / 2}=138,4\right.$ dias, $\left.\mathrm{E}_{\alpha}=5,31 \mathrm{MeV}\right)$ e que, finalmente, gera o elemento estável ${ }^{206} \mathrm{~Pb}$.

$\mathrm{O}{ }^{210} \mathrm{~Pb}$ e o ${ }^{210} \mathrm{Po}$ podem ser detectados distantes do suposto local de liberação, como resultado da extrema mobilidade do gás ${ }^{222} \mathrm{Rn}$. $\mathrm{O}$ rápido decaimento deste radionuclídeo gera ${ }^{210} \mathrm{~Pb}$ que, na atmosfera, é adsorvido pelos aerossóis e retorna ao ambiente terrestre e aquático por deposição superficial ou pela ação da chuva e neve. O tempo de residência do ${ }^{210} \mathrm{~Pb}$ na atmosfera varia de 9,6 dias a algumas semanas.

Segundo Parfenov (1974), a presença de ${ }^{210} \mathrm{~Pb}$ na água é resultado da deposição atmosférica ("fallout") e da lixiviação do solo e das rochas. Estes radionuclídeos são gerados pelo ${ }^{222} \mathrm{Rn}$, que é solúvel em água, e pode estar presente em lençóis freáticos, assim como em águas superficiais.

O ${ }^{210} \mathrm{~Pb}$ está presente no solo como resultado do decaimento dos radionuclídeos da série do ${ }^{238} \mathrm{U}$ ou por precipitação dos filhos do radônio da atmosfera.

$\mathrm{O}{ }^{210} \mathrm{~Pb}$ e seus produtos de decaimento são importantes traçadores naturais para estudos de processos atmosféricos, terrestres e oceânicos, especialmente para obtenção de valores de taxas de sedimentação de ambientes aquáticos.

Estudos sobre a taxa de sedimentação baseados nos radionuclídeos da série de decaimento do Urânio se baseiam diretamente no pressuposto de equilíbrio radioativo entre o radionuclídeo e o seu elemento de decaimento.

Em muitos ambientes, ${ }^{210} \mathrm{~Pb}$ está presente em excesso com relação a seu precursor, o ${ }^{226} \mathrm{Ra}$. Esse excesso ocorre porque um intermediário na série de decaimento, ${ }^{222} \mathrm{Rn}$ é volátil e escapa de solos áridos para a atmosfera. ${ }^{222} \mathrm{Rn}$ decai 
na atmosfera para $\circ{ }^{210} \mathrm{~Pb}$, o qual é rapidamente adsorvido nas partículas e aerossóis. Esses são lavados da atmosfera por precipitação e depositados no meio aquático (oceanos, mares, estuários, rios, lagos, gelo). Como resultado, o $\mathrm{Pb}-210$ está presente em excesso ao ${ }^{226} \mathrm{Ra}$, e é denominado ${ }^{210} \mathrm{~Pb}$ não-suportado (em excesso). Sua atividade geralmente diminui com a profundidade em uma coluna de sedimento.

O chumbo formado no sedimento pelo decaimento do ${ }^{226} \mathrm{Ra}$, está em equilíbrio radioativo com o mesmo, e é denominado ${ }^{210} \mathrm{~Pb}$ suportado (em equilíbrio). Portanto, os níveis de chumbo em camadas de sedimento mais profundas correspondem à concentração do ${ }^{210} \mathrm{~Pb}$ no solo, transportado para o ambiente marinho pelos rios, enquanto que as concentrações medidas para este radionuclídeo nas camadas superiores estão em excesso em relação ao ${ }^{226} \mathrm{Ra}$, sugerindo que $0{ }^{210} \mathrm{~Pb}$ não se originou somente do sedimento e minerais do solo.

A concentração de ${ }^{210} \mathrm{~Pb}$ não suportado diminui quando a profundidade dos depósitos aumenta, devido ao seu decaimento radioativo. O gradiente de tal diminuição fornece a base para a determinação da taxa de sedimentação.

Perfis anômalos de ${ }^{210} \mathrm{~Pb}$ em testemunhos podem estar relacionados à diminuição da taxa de sedimentação ou entrada repentina de sedimento de desmoronamentos ou de atividades antrópicas.

Desde sua elaboração o método de obtenção de taxas de sedimentação, baseado no decaimento radioativo do ${ }^{210} \mathrm{~Pb}$ tem sido utilizado usando a técnica básica, modelo e pressupostos teóricos como originalmente proposto por Goldberg (1963, apud Noller, 2000).

Devido à sua meia vida relativamente baixa ( $\pm 22,3$ anos), o método de obtenção de taxas de sedimentação, predominantemente utilizado para registros sedimentares de ambientes lacustres e marinhos rasos, tem seu intervalo de confiança restrito a um período de tempo não muito superior a um século.

A precisão dos resultados obtidos é uma conjugação de diferentes fatores que englobam, desde a garantia da estabilidade do radionuclídeo junto à matriz ao qual foi incorporado em seu processo de sedimentação, até a precisão do detector 
utilizado no procedimento de contagem das emissões das particulas beta ou dos raios gama.

\subsection{Metodologias de análise}

\subsubsection{Datações ${ }^{14} \mathrm{C}$}

As datações ${ }^{14} \mathrm{C}$ foram realizadas pela técnica do AMS, nos laboratórios Beta Analytics, USA, em 15 (quinze) amostras de 9 (nove) testemunhos da margem continental sul paulista.

A ausência de conchas ou fragmentos vegetais dispersos nas seqüências sedimentares amostradas implicou na opção pelo emprego da técnica do AMS, que compreende uma pré-concentração do carbono contido no material submetido à datação, diretamente em sedimentos selecionados de intervalos fatiados das colunas sedimentares amostradas.

A partir das datações obtidas foram determinadas as idades de todas as camadas das seqüências sedimentares dos 9 (nove) testemunhos, pelo emprego de técnica de interpolação de idades em camadas que não dispõem de datação, através da aplicação do Programa DepAge, versão 3.9, desenvolvido por L.J. Maher Jr., que executa um ajuste linear entre pontos de controle, ou seja, os níveis que possuem datação.

É assumido como tendo idade zero (2000), os níveis da superfície de topo de todos os testemunhos considerados.

\subsubsection{Determinação do ${ }^{210} \mathrm{~Pb}$}

${ }^{210} \mathrm{~Pb}$ pode ser determinado por um método instrumental por meio da emissão de seus raios gama (47 keV). Este método requer um detector que seja sensível a raios gama de baixa energia e que também possua baixa radiação de fundo e alta eficiência de detecção e contagem. Além disso, a análise necessita de um estudo detalhado para corrigir a atenuação da radiação por auto-absorção, o que deve ser feito para cada matriz estudada.

Neste trabalho, as amostras de sedimento foram acondicionadas em recipientes de plástico $(2,5 \times 6,0 \mathrm{~cm})$ até $1,5 \mathrm{~cm}$ de altura, tampadas e os 
recipientes foram totalmente cobertos com um filme plástico e, em seguida, colocados sobre o detector de Germânio, para análise por cerca de $80.000 \mathrm{~s}$.

Introduziu-se um comando no programa MAESTRO "for Windows", da EG\&G ORTEC, que permitiu detecções acumulativas da radiação gama do ${ }^{210} \mathrm{~Pb}$ no material analisado e na amostra do branco, com acúmulo de detecções programáveis a cada $10.000 \mathrm{~s}$, a partir de $30.000 \mathrm{~s}$. Todos os fotopicos dos espectros passaram por um processo de "alisamento" (smoothing) dentro do próprio programa, antes da análise (FIGUEIRA et al., 1997).

Para a detecção foi utilizado um detector de germânio hiper-puro, tipo GMX 25190P, analisador multicanal SPECTRUM MASTER ${ }^{\text {TM }}$, modelo 92X-II, da EG\&G/ORTEC, acoplados a um microcomputador, onde o programa de aquisição coleta os dados através de uma placa de 8192 canais. Este espectrômetro de raios gama apresenta boa sensibilidade à radiação gama de baixa energia, sendo adequado para a análise de ${ }^{210} \mathrm{~Pb}$.

A análise do branco foi realizada em paralelo às análises das amostras. Esta análise consistiu na detecção do radionuclídeo, como descrito acima, sem a utilização das amostras, ou seja, somente o recipiente para detecção.

${ }^{210} \mathrm{~Pb}$ emite raios gama de baixa energia (47 keV) que necessitam de correção por causa da atenuação da radiação por auto-absorção, o que deve ser feito para cada matriz estudada. Para esta correção foi utilizada uma fonte puntual de Am-241. Neste caso, cada amostra foi detectada por $300 \mathrm{~s}$, com a fonte sobre o recipiente, e 300s sem a fonte de Am-241.

O fator de auto-absorção para cada amostra foi determinado segundo a Equação 1:

$$
F=\frac{\ln A / N}{A / N-1}
$$

em que, 
F é o fator de auto-absorção;

A é o número de contagens do ${ }^{241} \mathrm{Am}$, com a amostra (cps);

$\mathrm{N}$ é o número de contagens do ${ }^{241} \mathrm{Am}$, sem a amostra (cps).

A atividade de ${ }^{210} \mathrm{~Pb}$ por espectrometria gama foi determinada como indicado na Equação 2:

$$
A=\frac{(C \times F)-B r}{t \times m \times p_{\gamma} \times \varepsilon_{P b-210}}
$$

em que,

$\mathrm{A}_{\mathrm{Pb}-210}$ é a atividade do ${ }^{210} \mathrm{~Pb}$ na amostra $\left(\mathrm{Bq} \cdot \mathrm{kg}^{-1}\right)$;

C é o número de contagens do ${ }^{210} \mathrm{~Pb}$ na amostra;

F é o fator de auto-absorção calculado pela Equação 1;

$\mathrm{Br}$ é o número de contagens da radiação de fundo na região do ${ }^{210} \mathrm{~Pb}(47 \mathrm{keV})$;

t é o tempo de contagem da amostra, em segundos;

$\mathrm{m}$ é a massa da amostra, em quilogramas;

$\mathrm{p}_{\gamma}$ é a probabilidade de emissão da radiação gama proveniente do $\mathrm{Pb}-210$ igual a 0,0418;

$\varepsilon_{\mathrm{Pb}-210}$ é a eficiência do detetor para ${ }^{210} \mathrm{~Pb}$ igual a $(12,7 \pm 3,8) \%$.

A análise direta de ${ }^{226}$ Ra por meio da sua radiação gama é muito complexa, pois, embora este emita um raio gama de $186 \mathrm{keV}$, sua intensidade é baixa, cerca de $4 \%$, além de sofrer a interferência do pico do ${ }^{235} \mathrm{U}$, de $185,7 \mathrm{keV}$. Outra forma de se analisar $\mathrm{O}^{226} \mathrm{Ra}$ por espectrometria gama é por meio dos seus produtos de decaimento ${ }^{214} \mathrm{Bi}$, com pico de $609 \mathrm{keV}$ e ${ }^{214} \mathrm{~Pb}$, com picos de $352 \mathrm{keV}$ e $295 \mathrm{keV}$. 
Esta análise requer um estudo detalhado para cada matriz, além do equilíbrio entre os radionuclídeos.

Para a determinação de ${ }^{226} \mathrm{Ra}$, por meio da emissão gama do ${ }^{214} \mathrm{Bi}\left(\mathrm{E}_{\gamma}=\right.$ $609 \mathrm{keV}$ ) é necessário que se estabeleça o equilíbrio entre $0{ }^{222} \mathrm{Rn}$, intermediário na cadeia, e o ${ }^{226} \mathrm{Ra}$. Segundo Canet \& Jacquemin (1990, apud Saito, 1996) cerca de $80 \%$ do equilíbrio permanece em amostras sólidas e esta relação é obtida totalmente após 20 dias de preparação da amostra. Desta forma, após a secagem, homogeneização e acondicionamento das amostras nos recipientes para detecção, essas foram guardadas por cerca de 20 dias e, em seguida, colocadas no detector para a determinação dos radionuclídeos.

A preparação das amostras, a sistemática para a detecção de ${ }^{226} \mathrm{Ra}$, a determinação da eficiência de detecção e a análise do branco foram efetuadas da mesma forma que as descritas para o chumbo. A atividade de Ra-226 por espectrometria gama foi obtida por meio da Equação 3:

$$
A_{R a-226}=\frac{C_{B i-214}-B r}{t \times m \times p_{\gamma} \times \varepsilon_{B i-214}}
$$

em que,

$\mathrm{A}_{\mathrm{Ra}-226}$ é a atividade do ${ }^{226} \mathrm{Ra}$ na amostra $\left(\mathrm{Bq} \cdot \mathrm{kg}^{-1}\right)$;

$\mathrm{C}_{\mathrm{Bi}-214}$ é o número de contagens do ${ }^{214} \mathrm{Bi}$ na amostra;

$\mathrm{Br}$ é o número de contagens da radiação de fundo na região do ${ }^{214} \mathrm{Bi}(609 \mathrm{keV})$;

t é o tempo de contagem da amostra, em segundos;

m é a massa da amostra, em quilogramas;

$\mathrm{p}_{\gamma}$ é a probabilidade de emissão da radiação gama proveniente do ${ }^{214} \mathrm{Bi}$ igual a 0,412 ; 
$\varepsilon_{\mathrm{Pb}-210}$ é a eficiência do detetor para o ${ }^{214} \mathrm{Bi}$ igual a $(4,0 \pm 0,8) \%$.

Os métodos desenvolvidos para a análise de ${ }^{210} \mathrm{~Pb}$ e ${ }^{226} \mathrm{Ra}$ foram aplicados em amostras de referência da Agência Internacional de Energia Atômica (IAEA), para a certificação e, em seguida aplicados nas amostras de sedimentos coletadas ao longo da plataforma continental da costa sul paulista.

A taxa de sedimentação foi calculada pela Equação 4:

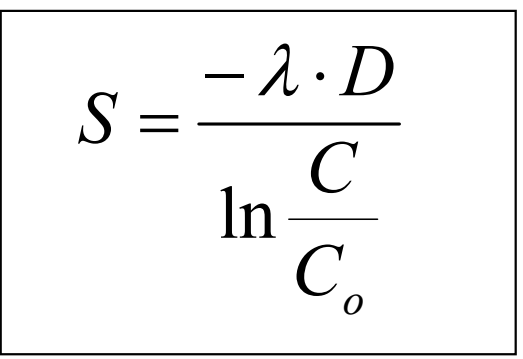

em que,

S é a taxa de sedimentação em $\mathrm{cm} \cdot \mathrm{ano}^{-1}$;

$\mathrm{C}_{\mathrm{Pb}-210}$ é a contagem do ${ }^{210} \mathrm{~Pb}$ não suportado ("unsupported)" na base do testemunho;

$\mathrm{CO}_{\mathrm{Pb}-210}$ é a contagem do ${ }^{210} \mathrm{~Pb}$ não suportado ("unsupported") no topo do testemunho;

$\lambda$ é a constante de decaimento radioativo do $\mathrm{Pb}-210$ igual a $0,31076 \mathrm{ano}^{-1}$;

D é distância entre o topo e o estrato medido, em centímetros. 


\subsection{Análise dos resultados}

\subsubsection{Datações ${ }^{14} \mathrm{C}$}

Os resultados das datações ${ }^{14} \mathrm{C}$ das quinze (15) amostras analisadas estão apresentados na Tabela 4.

A datação ${ }^{14} \mathrm{C}$ mais antiga foi conseguida no testemunho $6651(28-30 \mathrm{~cm}$ de profundidade), com idade calibrada de 3550 anos (B.P.), e a mais recente de 1100 anos (B.P.), no nível entre $02-04 \mathrm{~cm}$ de profundidade do testemunho 6683.

Analisadas as idades ${ }^{14} \mathrm{C}$ calibradas, sem considerar os fenômenos de adensamento e compactação das colunas sedimentares tem-se, para os testemunhos coletados na isóbata de 100 metros, um valor de taxa de sedimentação, para toda a coluna sedimentar, da ordem de 0,23 mm/ano.

\begin{tabular}{|c|c|c|c|}
\hline Testemunho & $\begin{array}{c}\text { Espessura } \\
\text { considerada }\end{array}$ & $\begin{array}{c}\text { Idade }{ }^{14} \mathrm{C} \text { calibrada } \\
\text { (anos B.P.) }\end{array}$ & $\begin{array}{c}\text { Taxa média de } \\
\text { sedimentação }\end{array}$ \\
\hline 6692 & $46 \mathrm{~cm}$ & 1610 anos & $0,28 \mathrm{~mm} / \mathrm{ano}$ \\
\hline 6696 & $44 \mathrm{~cm}$ & 1775 anos & $0,25 \mathrm{~mm} / \mathrm{ano}$ \\
\hline 6700 & $34 \mathrm{~cm}$ & 1580 anos & $0,22 \mathrm{~mm} / \mathrm{ano}$ \\
\hline 6704 & $30 \mathrm{~cm}$ & 1615 anos & $0,19 \mathrm{~mm} / \mathrm{ano}$ \\
\hline 6683 & $42 \mathrm{~cm}$ & 2115 anos & $0,20 \mathrm{~mm} / \mathrm{ano}$ \\
\hline
\end{tabular}

No perfil aproximadamente perpendicular à costa, as taxas de sedimentação média variaram de um mínimo de 0,04mm/ano (testemunho 6652), até um máximo de $0,15 \mathrm{~mm} / \mathrm{ano}$ (testemunho 6654).

\begin{tabular}{|c|c|c|c|}
\hline Testemunho & $\begin{array}{c}\text { Espessura } \\
\text { considerada }\end{array}$ & $\begin{array}{c}\text { Idade }{ }^{14} \mathrm{C} \text { calibrada } \\
\text { (anos B.P.) }\end{array}$ & $\begin{array}{c}\text { Taxa média de } \\
\text { sedimentação }\end{array}$ \\
\hline 6651 & $30 \mathrm{~cm}$ & 3530 anos & $0,08 \mathrm{~mm} /$ ano \\
\hline 6652 & $12 \mathrm{~cm}$ & 2695 anos & $0,04 \mathrm{~mm} /$ ano \\
\hline 6653 & $12 \mathrm{~cm}$ & 1990 anos & $0,06 \mathrm{~mm} / \mathrm{ano}$ \\
\hline 6654 & $36 \mathrm{~cm}$ & 2375 anos & $0,15 \mathrm{~mm} /$ ano \\
\hline
\end{tabular}


Ao longo da isóbata de 100 metros, considerados apenas as datações efetuadas no nível $02-04 \mathrm{~cm}$ de profundidade, dos testemunhos datados neste nível, obtém-se um valor médio de taxa de sedimentação para o intervalo de $0,03 \mathrm{~mm} / \mathrm{ano}$

\begin{tabular}{|l|l|l|l|}
\hline Testemunho & $\begin{array}{l}\text { Espessura } \\
\text { considerada }\end{array}$ & $\begin{array}{l}\text { Idade }{ }^{14} \mathrm{C} \text { calibrada } \\
\text { (anos B.P.) }\end{array}$ & $\begin{array}{l}\text { Taxa média de } \\
\text { sedimentação }\end{array}$ \\
\hline 6692 & $04 \mathrm{~cm}$ & 1315 anos & $0,03 \mathrm{~mm} /$ ano \\
\hline 6696 & $04 \mathrm{~cm}$ & 1400 anos & $0,03 \mathrm{~mm} /$ ano \\
\hline 6700 & $04 \mathrm{~cm}$ & 1160 anos & $0,03 \mathrm{~mm} / \mathrm{ano}$ \\
\hline 6704 & $04 \mathrm{~cm}$ & 1235 anos & $0,03 \mathrm{~mm} /$ ano \\
\hline 6683 & $04 \mathrm{~cm}$ & 1100 anos & $0,04 \mathrm{~mm} / \mathrm{ano}$ \\
\hline
\end{tabular}

Desta forma, quando confrontadas as taxas de sedimentação obtidas, para diferentes intervalos de um mesmo testemunho, evidencia-se uma disparidade entre as ordens de grandeza dos valores obtidos.

\begin{tabular}{|c|c|c|}
\hline Testemunho & $\begin{array}{c}\text { Taxa média de } \\
\text { sedimentação }\end{array}$ & Fator multiplicativo \\
\hline $6651(00-04 \mathrm{~cm})$ & $0,02 \mathrm{~mm} / \mathrm{ano}$ & 1,0 \\
\hline $6651(00-46 \mathrm{~cm})$ & $0,08 \mathrm{~mm} /$ ano & 4,0 \\
\hline $6683(00-04 \mathrm{~cm})$ & $0,03 \mathrm{~mm} / \mathrm{ano}$ & 1,0 \\
\hline $6683(00-42 \mathrm{~cm})$ & $0,20 \mathrm{~mm} / \mathrm{ano}$ & 6,7 \\
\hline $6692(00-04 \mathrm{~cm})$ & $0,03 \mathrm{~mm} / \mathrm{ano}$ & 1,0 \\
\hline $6692(00-46 \mathrm{~cm})$ & $0,28 \mathrm{~mm} / \mathrm{ano}$ & 9,3 \\
\hline $6692(00-04 \mathrm{~cm})$ & $0,03 \mathrm{~mm} / \mathrm{ano}$ & 1,0 \\
\hline $6696(00-44 \mathrm{~cm})$ & $0,25 \mathrm{~mm} / \mathrm{ano}$ & 8,3 \\
\hline $6700(00-04 \mathrm{~cm})$ & $0,03 \mathrm{~mm} / \mathrm{ano}$ & 1,0 \\
\hline $6700(00-34 \mathrm{~cm})$ & $0,22 \mathrm{~mm} / \mathrm{ano}$ & 7,3 \\
\hline $6704(00-04 \mathrm{~cm})$ & $0,03 \mathrm{~mm} / \mathrm{ano}$ & 1,0 \\
\hline $6704(00-30 \mathrm{~cm})$ & $0,19 \mathrm{~mm} / \mathrm{ano}$ & 6,3 \\
\hline
\end{tabular}


Esta aparente disparidade reflete as questões relacionadas às imprecisões em se datar sedimentos coletados muito próximos à superfície de fundo atual, dos quais foram extraídos e pré-concentrados o carbono, por AMS.

Desta forma, são mais confiáveis e significativas datações obtidas para as seqüências de base dos testemunhos, preservadas de contaminação em um ambiente semi fechado e, por conseguinte os valores de taxas de sedimentação calculados para a seqüência amostral completa.

A partir das idades interpoladas, calculadas por ajuste linear para os testemunhos da isóbata de 100 metros, verifica-se uma tênue tendência de aumento das taxas de sedimentação média, para o período considerado, no sentido sul, sendo o testemunho 6692 o que apresenta a taxa de sedimentação milenar mais elevada $(0,29 \mathrm{~mm} / \mathrm{ano})$, ainda que da mesma ordem de grandeza das taxas obtidas pelo cálculo direto, sem a interpolação das idades (Figura 22).

\begin{tabular}{|c|c|c|c|}
\hline Testemunho & $\begin{array}{c}\text { Espessura } \\
\text { considerada }\end{array}$ & $\begin{array}{c}\text { Idade interpolada } \\
\text { (anos B.P.) }\end{array}$ & $\begin{array}{c}\text { Taxa média de } \\
\text { sedimentação }\end{array}$ \\
\hline 6692 & $46 \mathrm{~cm}$ & 1560 anos & $0,29 \mathrm{~mm} /$ ano \\
\hline 6696 & $46 \mathrm{~cm}$ & 1725 anos & $0,27 \mathrm{~mm} / \mathrm{ano}$ \\
\hline 6700 & $34 \mathrm{~cm}$ & 1530 anos & $0,22 \mathrm{~mm} / \mathrm{ano}$ \\
\hline 6704 & $30 \mathrm{~cm}$ & 1565 anos & $0,19 \mathrm{~mm} / \mathrm{ano}$ \\
\hline 6683 & $42 \mathrm{~cm}$ & 2065 anos & $0,20 \mathrm{~mm} / \mathrm{ano}$ \\
\hline
\end{tabular}

Para o perfil aproximadamente perpendicular à costa, o testemunho coletado na isóbata de 90 metros (test. 6654) indica uma taxa de sedimentação média pouco inferior aos valores médios das taxas obtidas para os testemunhos coletados ao longo da isóbata de 100 metros $(0,14 \mathrm{~mm} / \mathrm{ano})$.

$\mathrm{Na}$ plataforma externa e talude superior as ordens de grandeza são significativamente menores, com valores oscilando entre $0,09 \mathrm{~mm} / \mathrm{ano}$ a $0,05 \mathrm{~mm} / \mathrm{ano}$. 


\begin{tabular}{|c|c|c|c|}
\hline Testemunho & Espessura & $\begin{array}{c}\text { Idade interpolada } \\
\text { (anos B.P.) }\end{array}$ & $\begin{array}{c}\text { Taxa média de } \\
\text { sedimentação }\end{array}$ \\
\hline 6651 & $30 \mathrm{~cm}$ & 3480 anos & $0,09 \mathrm{~mm} / \mathrm{ano}$ \\
\hline 6652 & $12 \mathrm{~cm}$ & 2645 anos & $0,05 \mathrm{~mm} / \mathrm{ano}$ \\
\hline 6653 & $12 \mathrm{~cm}$ & 1945 anos & $0,06 \mathrm{~mm} / \mathrm{ano}$ \\
\hline 6654 & $33 \mathrm{~cm}$ & 2325 anos & $0,14 \mathrm{~mm} / \mathrm{ano}$ \\
\hline
\end{tabular}

A representação espacial das idades interpoladas, por testemunho indica, para a plataforma média, valores de taxa de sedimentação correlacionáveis com a faixa de sedimentos lamosos dispostos ao longo da isóbata de 100 metros (Figura 23).

A taxa de sedimentação média, obtida para o testemunho do talude superior (testemunho 6651), é superior às taxas de sedimentação obtidas para os testemunhos da plataforma externa (testemunhos 6652 e 6653), podendo significar a ocorrência de processos deposicionais mais efetivos no talude superior, em relação aos operantes na plataforma externa sul-paulista ou, mesmo, a ocorrência de deslizamentos na região do talude superior. Neste último caso os valores obtidos de taxa de sedimentação não podem ser considerados representativos de processos deposicionais, uma vez que pode ter havido o completo revolvimento da coluna sedimentar.

Porém, a descrição das seqüências coletadas não indica, em princípio, a existência de evidências que possibilitem a suposição de ocorrência de fenômenos de deslizamentos, visto a seqüência sedimentar do testemunho 6651 se apresentar como uma massa homogênea, maciça, com fragmentos biodetríticos finamente dispersos ao longo de todo o testemunho, sem a presença de estruturas visíveis de ruptura ou mudança brusca de nível de energia deposicional.

As taxas de sedimentação, baseadas nas datações ${ }^{14} \mathrm{C}$, obtidas para a plataforma continental sul paulista, não são diretamente comparáveis a nenhum 
outro valor obtido para a plataforma continental brasileira, pois que as únicas taxas de sedimentação baseadas no emprego da técnica do ${ }^{14} \mathrm{C}$ (AMS) foram obtidas por Arz et.al. (1999 ạ; $\underline{b}$ ), em testemunhos do talude médio das regiões leste e nordeste do Brasil.

$\mathrm{Na}$ margem continental nordeste, aproximadamente entre Recife (PE) e Fortaleza (CE), em profundidades de coleta superiores a 770 metros, os autores indicaram uma variação das taxas médias ao longo dos últimos 22.000 anos, sendo os valores médios obtidos para todo o período compreendido entre um máximo de 0,24 mm/ano e um valor mínimo, junto a atual superfície de fundo, de $0,05 \mathrm{~mm} / \mathrm{ano}$.

$\mathrm{Na}$ margem leste, nas proximidades de Vitória (ES), ainda em profundidades superiores a 780 metros, foram obtidas taxas médias da ordem de $0,045 \mathrm{~mm} / \mathrm{ano}$, bastante inferiores às calculadas para a margem nordeste.

Muito embora as taxas de sedimentação obtidas na plataforma sul paulista apresentem uma variação de valores $(0,28$ a 0,03$) \mathrm{mm} / \mathrm{ano}$, comparável com as obtidas para o Pleistoceno tardio e o Holoceno da margem continental nordeste, quando confrontadas com a margem leste (Vitória), apresentam valores significativamente mais elevados, à exceção das taxas obtidas para as camadas de topo cujos valores são da mesma ordem de grandeza.

\subsubsection{Espectrometria Gama $\left({ }^{210} \mathrm{~Pb}\right)$}

A partir dos dados da concentração ${ }^{210} \mathrm{~Pb}_{\text {não suportado nos diferentes }}$ testemunhos foram construídos gráficos da concentração deste em função da profundidade. Estes gráficos estão apresentados nas Figuras 24 a 34 . Pode-se também observar que todos os resultados foram ajustados, obtendo-se então a equação da reta e o coeficiente de correlação de Pearson.

O coeficiente de correlação de Pearson mostrou uma forte correlação

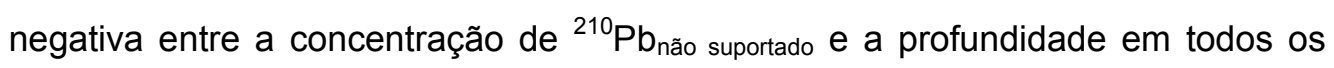
testemunhos. Calculando-se $\circ \mathrm{R}^{2}$ foi possível observar que, na maioria dos 
testemunhos, os dados correlacionados foram superiores a 0,75 , excetuando-se $o$ testemunho 6696 com um valor de 0,66 .

Assim, foi possível calcular a taxa de sedimentação a partir da equação da reta obtida para cada testemunho. Os resultados estão apresentados na Tabela 5, o valor médio das taxas de sedimentação para a região de estudo foi de $(2,02 \pm$ $0,57) \mathrm{mm} / \mathrm{ano}$, excetuando-se o testemunho $6683(0-22 \mathrm{~cm})$.

Para a plataforma externa e o talude superior foram calculados valores de taxa de sedimentação secular significativamente menores $(1,01 \pm 0,4)$ a $(1,45 \pm$ $0,5) \mathrm{mm} / \mathrm{ano}$, dos valores obtidos para a plataforma média sul-paulista $(3,05 \pm$ $0,46)$ a $(2,17 \pm 0,1) \mathrm{mm} /$ ano.

Os resultados obtidos para a plataforma média entre as isóbatas de 80 e 90 metros são superiores aos valores encontrados para os testemunhos coletados ao longo da isóbata de 100 metros, à exceção do testemunho localizado mais ao sul (6692), que indica uma taxa de sedimentação, para os últimos 100 anos, da mesma ordem de grandeza das obtidas para a plataforma média.

Ao longo da isóbata de 100 metros as taxas de sedimentação oscilaram entre um valor mínimo de $(1,74 \pm 0,43) \mathrm{mm} / \mathrm{ano}$, para o testemunho central do perfil (testemunho 6700), até um valor máximo de $(2,62 \pm 0,36) \mathrm{mm} / \mathrm{ano}$, na posição mais ao sul da área (testemunho 6692).

Consideradas as taxas de sedimentação de todas as seqüências sedimentares analisadas obtém-se uma taxa média de $(2,02 \pm 0,57) \mathrm{mm} / \mathrm{ano}$, cuja representatividade é relativa na medida em que os compartimentos fisiográficos da plataforma e talude superior sul paulistas, não estão eqüitativamente ponderados nesta média.

Consideradas apenas as seqüências sedimentares coletadas na plataforma média (80 a 100 metros), a taxa de sedimentação obtida é de $(2,22 \pm 0,42)$ $\mathrm{mm} / \mathrm{ano}$, superior à média obtida para os testemunhos coletados ao longo da isóbata de 100 metros $(2,06 \pm 0,29) \mathrm{mm} / \mathrm{ano}$. Esta média obtida é numericamente superior às médias obtidas para todos os testemunhos do perfil, à exceção do 
valor médio do testemunho mais ao sul da área, indicando ocorrer, ao longo dos últimos 100 anos, um processo deposicional mais intenso ao sul da área de estudo.

O segmento mais a NE do perfil, aproximadamente paralelo à linha de costa atual (100 metros), indica ainda a provável ocorrência de um segundo núcleo deposicional mais intenso (testemunho 6704 e 6683), principalmente se considerada a taxa de sedimentação obtida para a seqüência superior do testemunho 6683 (00 a $22 \mathrm{~cm}$ de profundidade), que apresentou uma taxa de sedimentação cujo valor é três vezes superior $(6,66 \mathrm{~mm} / \mathrm{ano} \pm 0,09)$ à média obtida para toda a plataforma média.

A ordem de grandeza das taxas de sedimentação, obtidas para a área, muito se assemelha à ordem de grandeza dos valores encontrados para outras plataformas continentais (Sommerfield \& Nittrouer, 1999; Fuller et.al.,1999; Somayajulu et.al., 1999), cujas taxas de sedimentação oscilam entre 0,6 a 6,6 mm/ano, para o período correspondente, aproximadamente os últimos 100 anos.

Especificamente para a plataforma continental brasileira, Patchineelam \& Smoak (1999), obtiveram taxas de sedimentação baseadas no estudo do decaimento radioativo do ${ }^{210} \mathrm{~Pb}$, embora não a partir de detecção instrumental das emissões gama, mas de um tratamento radioquímico para detecção beta.

Os valores obtidos para a plataforma interna, junto às desembocaduras fluviais dos rios Pardo, Jequitinhonha e Doce apresentaram taxas variando entre 2,3 e 4,2 mm/ano, enquanto que, para os canais da região do banco de Caravelas, ao sul de Alcobaça e norte dos rios Mucurí e São Mateus, os valores obtidos são mais elevados (5,1 mm/ano), atingindo um valor máximo de $8,1 \mathrm{~mm} / \mathrm{ano}$.

As taxas médias obtidas para a plataforma paulista são pouco inferiores às da plataforma leste e nordeste, as quais estão associadas desembocaduras fluviais de drenagens de maior porte, relativamente à drenagem do Rio Ribeira de Iguape, potencial fonte atual de aporte de sedimentos para a plataforma sul paulista.

Esta associação de plataformas continentais com taxas de sedimentação secular mais elevadas, com drenagens de porte que alimentam atualmente estes 
compartimentos marinhos rasos, é observada na margem continental leste do Mar da Arábia (Somayajulu et.al.,1999), na baia de São Francisco, California, USA, (Fuller et.al.,1999), e na plataforma continental oeste dos USA junto à desembocadura do Rio Eel ( Sommerfield \& Nittrouer, 1999).

Desta forma, muito embora puntualmente tenham sido obtidas taxas de valor elevado $(3,05 \mathrm{~mm} / \mathrm{ano}$, test.6655), o obtido para a plataforma média, com densidade amostral significativa, indica um valor médio de $(2,22 \pm 0,24) \mathrm{mm} / a n o$ caracterizando a área como uma plataforma continental com menor intensidade de aporte de sedimentos continentais atuais. 


\section{DISCUSSÃO DOS RESULTADOS}

A distribuição dos sedimentos de fundo da plataforma continental sul do Estado de São Paulo se apresenta disposta em faixas, aproximadamente, paralelas entre si e em relação à atual linha de costa.

Esta distribuição textural, controlada diretamente pelos mecanismos hidrodinâmicos e meteorológicos atuantes no sul/sudeste do Brasil, está refletida nas seqüências sedimentares de topo dos testemunhos analisados.

A homogeneidade destas colunas sedimentares é forte indicativo da persistência das condições hidrodinâmicas que controlam atualmente a dinâmica sedimentar da área, por um período de tempo mais longo. Este predomínio deve estar atuante desde, pelo menos, o início do afogamento da plataforma continental, após o Último Máximo Glacial.

De acordo com Suguio \& Martin (1978), para o sul do Estado de São Paulo, o nível do mar no Holoceno atingiu cotas de até quatro (4) metros, acima do nível atual ( 5.100 anos A.P.). Desta forma, durante este evento transgressivo a linha de costa deve ter avançado até a base do complexo serrano à retaguarda (Serra do Mar), ocasionando um total afogamento da drenagem que flui em direção às planícies costeiras atuais e, conseqüentemente, retendo os sedimentos terrígenos sobre as atuais planícies e ou nas proximidades da atual linha de costa. No decorrer da pequena regressão que se seguiu ao máximo transgressivo de 5.100 anos A.P., um pequeno mas eficiente retrabalhamento da drenagem foi reestabelecido (Mahiques, et.al., no prelo).

Segundo Mahiques et.al. (op.cit.), para os últimos 5.000 anos cada leve mudança que afetou a sedimentação na plataforma continental, do embaiamento de São Paulo, pode ser relacionada às mudanças do nível do mar holocênico. A concentração de sedimentos terrígenos ao longo da plataforma média ( 100 metros), com valores superiores a $75 \%$, denota uma extrema homogeneidade dos sedimentos, ao longo de todas as colunas sedimentares analisadas, constituídos basicamente de lamas, com diminuta contribuição de areias muito finas, apresentando elevados teores de matéria orgânica (carbono orgânico e nitrogênio 
total), dos elementos metálicos, e apresentando também teores inferiores a $20 \%$ de constituintes biodetríticos.

Com relação aos teores dos elementos metálicos, a plataforma média apresenta valores superiores, em até três (3) vezes, aos teores obtidos para os sedimentos da plataforma interna e externa e os do talude superior.

Ao longo da isóbata de 100 metros é possível verificar que o elemento cobre está homogeneamente distribuído, sem apresentar uma tendência de crescimento dos teores para qualquer rumo.

Já a análise dos teores de metal chumbo indica uma ligeira tendência de crescimento do quadrante $\mathrm{S}$ para $\mathrm{NE}$, até a seqüência de topo dos testemunhos 6704 e 6683, que apresentam os teores mais elevados. A seqüência de base do testemunho 6683 apresenta uma quebra desta tendência, na medida que as ordens de grandeza dos teores de chumbo obtidas são correlacionáveis às áreas de menor concentração do elemento.

Para o metal zinco o comportamento é ligeiramente diferenciado, na medida que, ao invés de indicar um sentido de aumento dos teores, ressalta a existência de dois núcleos de concentração, sendo um mais ao sul (testemunho $6692 \mathrm{e}$ 6696), com teores pouco mais elevados, e um segundo mais a NE (testemunho 6683), com teores pouco inferiores aos observados para a área mais a sul.

A porção mais a NE desta área da plataforma média representa uma ruptura das condições hidrodinâmicas de sedimentação, expressa pela alteração das características texturais, composicionais e geoquímicas dos sedimentos da seqüência sedimentar analisada (testemunho 6678), com as identificadas ao sul, ao longo da faixa de ocorrência atual dos sedimentos lamosos ( 100 metros).

As áreas mais internas da plataforma média ( $\sim 80$ a 90 metros) se constituem ainda em fácies de sedimentos terrígenos, porém com concentrações mais elevadas de sedimentos arenosos muito finos em relação à área limítrofe (100 metros) e teores inferiores de carbono orgânico e nitrogênio total, cobre, chumbo e zinco, mas ainda bem mais elevados relativamente aos teores de lama, 
matéria orgânica e dos metais encontrados nos sedimentos das fácies das plataformas interna e externa e do talude superior.

Os dados obtidos a partir das análises dos elementos metálicos não foram conclusivos na tentativa de uma correlação direta entre as fontes continentais de sedimentos, das áreas mineralizadas do Vale do Ribeira, e os sedimentos, depositados na plataforma continental sul-paulista. Porém, uma análise comparativa entre as ordens de grandeza dos teores dos elementos metálicos encontrados nos sedimentos da plataforma e o "background" regional dos sedimentos do Complexo Serrano, à retaguarda, em especial as rochas mineralizadas do Vale do Ribeira indicam que, ao longo de todos os compartimentos fisiográficos estudados, os teores de chumbo são comparáveis à média regional (16ppm) (Moraes, 1997). Anormalmente altos, com relação a este valor médio, são os teores dos sedimentos da plataforma média (isóbata de 100 metros), cujos valores variam entre a média regional e teores superiores ao dobro deste valor (41ppm).

De acordo com Moraes (1997), o "background" regional do cobre é de $18 \mathrm{ppm}$ e o do zinco de $47 \mathrm{ppm}$, enquanto as variações dos teores médios destes elementos, ao longo da isóbata de 100 metros, ocorrem entre teores da mesma ordem de grandeza, de $17 \mathrm{ppm}$ para o cobre e $59 \mathrm{ppm}$ para o zinco, até valores máximos de 22ppm para o cobre e de 86ppm para o zinco.

Os teores mais elevados de chumbo e zinco, observados nos sedimentos deste perfil, são equivalentes ao "background" destes elementos para a região das minas de chumbo desativadas do Alto Vale do Ribeira, ou seja, de 35ppm para o chumbo e de 70ppm para o zinco (Corsi, 1999).

Porém, uma comparação entre as razões isotópicas dos sedimentos mineralizados do Alto Vale, com os sedimentos da plataforma sul paulista, evidenciou uma perfeita diferenciação entre estes conjuntos de sedimentos.

O campo de variação das razões isotópicas dos sedimentos da plataforma não se sobrepõe ao obtido por Moraes (1997), para os sedimentos da drenagem Ribeira de Iguape, ou das áreas de jazimento do Alto Vale, mas a dos sedimentos 
representativos de terrenos vulcânicos e sedimentares proterozóicos e de granitóides de idade Fanerozóica.

Moraes (op.cit.), indica que as amostras de sedimentos da calha do Rio Ribeira de Iguape apresentam, no geral, à medida que se aproximam da foz, composições isotópicas mais "altas" com um gradativo deslocamento de suas razões na direção dos sedimentos representativos do embasamento cristalino das áreas não mineralizadas. Segundo o autor, este comportamento seria o resultado do decréscimo da concentração de chumbo ao longo do curso do rio e da entrada de chumbo carreado pelos afluentes que drenam litologias diferenciadas, resultando na diminuição da participação relativa do chumbo advindo das áreas de jazimento.

No litoral centro/sul paulista e norte paranaense os principais elementos de exportação de sedimentos terrígenos em suspensão (lamas e matéria orgânica), para o sistema marinho, são as desembocaduras da Baía de Paranaguá, as do Sistema Cananéia-Iguape (Ararapira, Cananéia e Icapara), a foz dos rios Ribeira de Iguape e Itanhaém e a desembocadura da Baía de Santos, além das pequenas drenagens originárias dos contrafortes da Serra.

Dentre todos estes sistemas, apenas a foz do Rio Ribeira de Iguape é, atualmente, exportadora dos sedimentos provenientes das áreas mineralizadas do Vale do Ribeira.

De acordo com Moraes (1997), os teores em chumbo dos sedimentos em suspensão da foz do Rio Ribeira de Iguape são cerca de 20 a 30 vezes inferiores aos teores dos sedimentos da calha do rio, coletados próximos das áreas mineralizadas. O teor de chumbo na foz do Ribeira de Iguape apresenta um valor de 26ppm, similar à média dos teores encontrados na isóbata de 100 metros, mas, por outro lado, com valores isotópicos mais próximos aos obtidos para os sedimentos das áreas de influência das mineralizações, comparativamente às razões determinadas para os sedimentos da plataforma.

Desta forma, é possivel se considerar os sedimentos terrígenos finos, depositados ao longo do Holoceno, na plataforma sul paulista, como originários, 
não apenas das áreas mineralizadas do Alto Vale, mas sim como uma somatória destas fontes, com os aportes provenientes das rochas de todo o Embasamento Cristalino, drenadas pelos pequenos cursos fluviais que deságuam na linha de costa, ou nos Sistemas Costeiros do litoral centro/sul paulista e norte paranaense.

A compreensão dos mecanismos de transferência destes sedimentos terrígenos, em suspensão, das regiões costeiras para a plataforma média é diminuta em razão das inexpressivas observações e medições sobre a movimentação de sedimentos em suspensão no litoral sul do Estado de São Paulo, bem como da importância deste transporte na circulação geral da área.

A observação da imagem MSS do satélite LANDSAT, nos canais 4 e 5 , obtida no dia 26/06/76, permite a avaliação de, pelo menos, uma situação geral da circulação em superfície, para todo o sul do Estado de São Paulo (Tessler,1988).

Nesta imagem é observada a nítida presença de plumas de material em suspensão entre a Praia Grande e o Morro da Juréia, com rumo de deslocamento para SW, além de outras menos nítidas, com o mesmo rumo de deslocamento em toda a área costeira compreendida entre Santos e a foz do Rio Ribeira de Iguape.

Nas proximidades da foz do Ribeira de Iguape e da desembocadura lagunar de Icapara, também podem ser observadas plumas de material em suspensão localizadas distantes da linha de costa.

Na porção média da llha Comprida também é observada, ortogonal à costa, uma nítida pluma de sedimentos, associada a uma outra pluma, posicionada próximo à desembocadura lagunar de Cananéia, com sentido de deslocamento para NE, ou seja, com sentido de deslocamento paralelo à llha Comprida (Figura 18).

Bonetti Filho (1995), é o único estudo que, além de identificar plumas de suspensão, no litoral sul paulista, apresenta medidas da concentração dos sedimentos em suspensão nas plumas identificadas.

Seus levantamentos temporais nas plumas associadas à desembocadura lagunar de Cananéia comprovam o sentido de deslocamento preferencial das mesmas rumo a NE, contendo sedimentos em suspensão de até $120 \mathrm{mg} / \mathrm{l}$. 
A partir da análise da imagem orbital de 1976, Tessler (1988) considerou a existência de dois sistemas de transporte de material em suspensão, de sentidos de deslocamentos opostos, ao longo do litoral sul paulista. O primeiro se desenvolve, preferencialmente, entre Santos e a foz do Rio Ribeira de Iguape, com sentido de deslocamento SW. O segundo se desloca no sentido nordeste entre a desembocadura lagunar de Cananéia e a foz do Ribeira. Entre a extremidade norte da Ilha Comprida e a foz do Ribeira de Iguape ocorre uma área de transição com as plumas direcionadas para o mar aberto (SE).

A pluma da porção média da llha Comprida representa um fluxo que se desloca rumo ao mar aberto, à semelhança das correntes de retorno ("rip current"), implicando no transporte de sedimentos em suspensão para além da zona de arrebentação das ondas na costa. Essas correntes de retorno podem ou não representar feições temporárias, geradas a partir do encontro de correntes de deriva litorânea com sentido de propagação opostas, ou pelo desvio de uma dessas correntes pelas irregularidades do fundo marinho. Entretanto, com respeito à efetividade e periodicidade deste evento, a falta de levantamentos mais sistematizados não permite precisar o fenômeno. Apesar disso, o deslocamento local das curvas batimétricas, no rumo do mar aberto, em segmento do litoral que apresenta um padrão batimétrico de curvas retilíneas e paralelas entre si e a linha de costa atual, é um forte indício da ocorrência periódica do fenômeno (Tessler, 1988).

Superimposto a este mecanismo e mais diretamente associado ao sistema meteorológico e da incidência das ondas sobre a costa é observado um processo de características mais amplas vinculado à dinâmica das massas d'água da margem continental.

Durante o verão, os ventos dominantes, de direção NW favorecem o deslocamento da Água Costeira (AC) para áreas mais externas da plataforma continental e, conseqüentemente a penetração, em subsuperfície da Água Central do Atlântico Sul (ACAS), para áreas mais rasas. O deslocamento da AC para áreas mais externas da plataforma continental causa o transporte de material terrígeno, em suspensão, para áreas mais profundas da plataforma. 
Este fato, comprovado por Mahiques (1998), para a região próxima à llha de São Sebastião, ainda não foi comprovado para a plataforma centro/sul paulista, muito embora já existam fortes indícios da sua efetividade, também para esta área.

O conhecimento da dinâmica de deslocamento para sul da Corrente do Brasil, nas plataformas média e externa e na região do talude superior parece indicar que os processos de sedimentação são influenciados por esta. Mahiques et.al. (no prelo), indicaram que o meandramento convoluto, observado por Campos (2000, apud Mahiques, op.cit.) da Corrente do Brasil, na região de Cabo Frio (Figura 19) tem reflexos na distribuição sedimentar e nas variações das taxas de sedimentação ao norte da llha de São Sebastião. As razões deste processo estão ligadas a mudanças de orientação da linha de costa, ao sul de Cabo Frio que, dinamicamente favorecem a formação dos meandramentos de giro horário da $\mathrm{CB}$, como uma tentativa de conservação do momento angular. A conseqüência seria, então, a formação de uma estrutura em vórtice com subida de água associada às áreas do sul do vórtice e mergulho de águas nas áreas a norte do giro.

"Em outras palavras o fluxo que cruza a plataforma, relacionado ao meandramento da Corrente do Brasil, controla o processo na plataforma externa e talude superior no Embaiamento de São Paulo. Entretanto, parece razoável supor que os processos sedimentares sobre a plataforma média e externa são alterados pelo meandramento da Corrente do Brasil, que fricciona superfície do fundo da plataforma (Mahiques et.al., no prelo).

A observação dos vórtices identificados por Mahiques et.al. (op.cit, Figura 19), mostra um vórtice se deslocando para áreas oceânicas entre as regiões de São Sebastião e Santos, com o giro sendo completado por um deslocamento no sentido da plataforma mais rasa, na região entre o litoral sul paulista e norte paranaense.

Nesta área o deslocamento do vórtice não projeta a CB diretamente sobre a plataforma média e externa, mas, sim, em direção às áreas oceânicas mais 
profundas. Este fenômeno permite o deslocamento efetivo da Água Costeira, das áreas mais internas para a plataforma externa ou para o talude superior.

Este mecanismo de deslocamento carreia os sedimentos em suspensão, aportados no meio marinho através das desembocaduras dos sistemas costeiros, podendo ser responsável pelos processos deposicionais mais intensos (isóbata de 100 metros), identificados na plataforma sul do Estado de São Paulo.

As taxas de sedimentação, de escala milenar, obtidas através das datações baseadas na técnica $\mathrm{AMS}$ para $0{ }^{14} \mathrm{C}$, indicam a região mais ao sul, ao longo da plataforma média, como a de maior taxa de sedimentação holocênica da plataforma sul-paulista, com valores cerca de $30 \%$ superiores que as áreas mais a NE. A região da plataforma externa detém taxas de sedimentação inferiores às obtidas para as áreas vizinhas do talude superior.

Em uma escala secular, realizada através da análise do decaimento radioativo do ${ }^{210} \mathrm{~Pb}$, foram observadas as mesmas tendências de taxas de sedimentação mais elevadas, a S/SW do perfil de 100 metros, acrescidas de valores também elevados obtidos para a plataforma média.

Os valores obtidos para as taxas seculares, bem como as baseadas no ${ }^{14} \mathrm{C}$, são bastante compatíveis com dados obtidos para plataformas continentais similares à do sul paulista e, também, com áreas de plataforma com forte aporte sedimentar proveniente de descarga fluvial de rios de porte. Sommerfield \& Nittrouer (1999), para a plataforma continental norte da California, correspondente a uma plataforma de compressão com forte descarga sedimentar do rio Eel, obtiveram valores médios de $4 \mathrm{~mm} / \mathrm{ano}$ para o período estimado dos últimos 100 anos, correspondentes à escala de confiabilidade da técnica de espectrometria gama do ${ }^{210} \mathrm{~Pb}$.

Fuller et.al. (1999), para a baía de São Francisco (USA), determinaram valores baseados no ${ }^{210} \mathrm{~Pb}$, de até $4,1 \mathrm{~cm} / a n o$, enquanto para o porto de Wellington, na Nova Zelandia as taxas atuais não são superiores a $5 \mathrm{~mm} / \mathrm{ano}$ (Goff Jr., 1998). 
Usando técnica similar à empregada neste estudo, no leste do Mar da China, Huh et.al. (1999), encontraram taxas de sedimentação, para os últimos 100 anos, bastante compatíveis com as obtidas para a plataforma sul paulista, variando de um máximo de $2 \mathrm{~cm} / \mathrm{ano}$, em áreas costeiras de forte aporte fluvial, até um mínimo de $0,2 \mathrm{~mm} /$ ano nas regiões do talude.

Patchineelam \& Smoak (1999), estudando a região da plataforma continental entre os estados da Bahia e do Espírito Santo, em especial a região de Abrolhos, obtiveram valores de até $8,1 \mathrm{~mm} / \mathrm{ano}$, no sudeste do canal de Caravelas $(\mathrm{Ba})$, e de cerca de 1,3mm/ano no talude superior da região do Rio Doce (ES). Estes valores, em especial o do canal de Caravelas, representam taxas muito elevadas, considerando-se que na região de Abrolhos predominam litologias carbonáticas com diminuta contribuição de sedimentos siliciclásticos.

Na plataforma norte paulista Mahiques et.al. (no prelo), obtiveram através do emprego de datações ${ }^{14} \mathrm{C}$, taxas holocênicas variando de um mínimo de 0,016 mm/ano, no talude médio e superior, a valores de 0,13mm/ano na região da plataforma rasa de Cabo Frio (RJ), muito inferiores às obtidas por Arz et.al. (1999, apud Mahiques et.al, op.cit.) para a região da plataforma norte do Brasil.

Para a plataforma sul-paulista as taxas de sedimentação, em escala secular (últimos 100 anos) e milenar $\left({ }^{14} \mathrm{C}\right)$, indicam ter existido, ao longo do Holoceno superior, uma forte contribuição de sedimentos terrígenos para a plataforma média. Esta contribuição representa a conjugação dos processos da dinâmica costeira, associados aos mecanismos climáticos do Atlântico Sul, associados aos efeitos do meandramento da Corrente do Brasil sobre o deslocamento da Água Costeira, e ao próprio processo de exportação de sedimentos terrígenos, determinado pelas características climáticas do litoral sudeste do Brasil.

O emprego, neste estudo, de técnicas de espectrometria gama e radiocarbono, para obtenção de taxas de sedimentação de alcances e precisões distintas, sobre um mesmo material sedimentar, revelou valores de ordem de grandeza muito diferenciados, para taxas milenares e seculares. Este fato revela a impossibilidade de utilização de ambas as técnicas como complementares no 
sentido de serem obtidos valores de taxas de sedimentação quaternárias mais confiáveis.

A caracterização de um nível dos testemunhos analisados (02 a $04 \mathrm{~cm}$ ), como possuindo idades da ordem de um milhar de anos, por datação ${ }^{14} \mathrm{C}$, e de apenas uma centena de anos, por espectrometria gama $\left({ }^{210} \mathrm{~Pb}\right)$, com fator multiplicativo de 9 (nove) vezes entre os valores obtidos, reflete uma somatória de imprecisões. Estas imprecisões podem estar associadas ao emprego da técnica de radiocarbono para sedimentos mais jovens do que 300 anos e da extração de todo o carbono (AMS) de sedimentos provavelmente representativos de um "sistema aberto", com possível impregnação por processos de percolação e/ou ressuspensão e ressedimentação, comuns em sedimentos de topo de colunas sedimentares de áreas marinhas rasas. A estas imprecisões estariam associados os erros inerentes ao emprego da metodologia de espectrometria gama, com reduzida mobilidade do isótopo de chumbo e, mesmo, de perturbações dos sedimentos superficiais por atividade biogênica.

Somayajulu et. al. (1999), estudando a região leste do Mar da Arábia, emprega ambas as técnicas de datação $\left({ }^{210} \mathrm{~Pb},{ }^{137} \mathrm{Cs} \mathrm{e}{ }^{14} \mathrm{C}\right)$. As datações ao ${ }^{14} \mathrm{C}$ foram feitas com a utilização de carapaças de foraminíferos plantônicos de seqüências do meio e da base dos testemunhos $(\geq 10 \mathrm{~cm})$, obtendo-se taxas de sedimentação de escala milenar $(0.004$ a $0.13 \mathrm{~cm} / \mathrm{ano})$. Os valores de taxas de sedimentação seculares foram atrelados apenas ao emprego das técnicas de espectrometria gama em sedimentos da seqüência de topo das colunas sedimentares $(>10 \mathrm{~cm})$, com taxas variando de um mínimo de 0.06 a $0.66 \mathrm{~cm} / \mathrm{ano}$.

Neste estudo os autores ignoram os dados de emissão gama de sedimentos coletados a profundidades maiores do que $10 \mathrm{~cm}$, na certeza de que átomos de meia vida reduzida $\left({ }^{210} \mathrm{~Pb}\right.$ e $\left.{ }^{137} \mathrm{Cs}\right)$, já atingiram seu equilíbrio radiogênico no decorrer do tempo de sedimentação de uma coluna sedimentar desta espessura.

Nos testemunhos analisados para a plataforma sul paulista esta aparente incoerência é ressaltada pela utilização de uma mesma amostra para a análise 
das duas escalas temporais. As taxas de sedimentação da área, como um todo, são melhor refletidas pelos valores obtidos pelas datações ${ }^{14} \mathrm{C}$, para toda a coluna sedimentar analisada, uma vez que essas são representativas de um conjunto de processos hidrodinâmicos e sedimentares de longo tempo (taxa milenar). Por outro lado, os valores obtidos pelo emprego da técnica de espectrometria gama são representativos de um mecanismo recente (taxa secular), onde ainda são significativos mecanismos de ressuspensão e ressedimentação, oscilações do ritmo e intensidade dos processos de sedimentação e bioturbação das camadas de topo da superfície atual dos fundos marinhos. 


\section{CONSIDERAÇÕES FINAIS}

O conhecimento dos valores das taxas de sedimentação holocênica obtidos para a plataforma continental sul paulista, de acordo com o objetivo principal proposto, se constitui em importante elemento no conhecimento da dinâmica sedimentar desta plataforma a partir do máximo transgressivo holocênico $(\sim 5.100$ anos).

Os valores, calculados através do emprego de análise instrumental de espectrometria gama para $0{ }^{210} \mathrm{~Pb}$, se constituem nos primeiros valores de taxa de sedimentação holocênica obtidos para a margem continental brasileira, através de análise não destrutiva das amostras.

Os resultados obtidos das análises isotópicas dos sedimentos da plataforma continental são indicativos seguros da contribuição de uma ampla área do embasamento como fonte atual do aporte sedimentar.

As fontes de aporte atual de sedimentos para a plataforma continental sul do Estado de São Paulo não estão apenas restritas ao Complexo Serrano do Vale do Ribeira, mineralizadas em metais bem determinados, mas a um conjunto mais amplo de fontes ligadas às rochas vulcânicas, granitóides e metamórficas de todo o embasamento do Fanerozóico do sistema serrano limítrofe da plataforma sul paulista.

Desta forma, sendo o Rio Ribeira de Iguape a única drenagem de expressão a desaguar junto à atual linha de costa do litoral sul paulista, verifica-se que o aporte de fontes diversificadas deve estar associado a um grande número de pequenas drenagens e desembocaduras de sistemas costeiros, que deságuam a sul e a norte da área de estudo.

Estas drenagens e sistemas costeiros embora limitados individualmente como partícipes dos mecanismos atuais de aporte sedimentar para a plataforma sul paulista podem, conjuntamente, compor um papel relevante no aporte da carga em suspensão similar, em ordem de grandeza, aos volumes exportados pelas drenagens de grande porte que atravessam extensas áreas continentais do globo. 
A comparação das taxas obtidas com valores de taxas de sedimentação, calculadas para outras áreas marinhas de plataforma continental, em especial de áreas alimentadas por sistemas fluviais atuais de expressão, indicam a efetividade da contribuição terrígena, para a plataforma sul paulista, ao longo do período analisado.

Porém, muito embora a drenagem Ribeira de Iguape não se constitua na fonte exclusiva de aporte de sedimentos terrígenos para a plataforma sul, sua contribuição é significativa, como indicado pelos elevados teores dos elementos metálicos, presentes nas colunas sedimentares estudadas, semelhantes, em ordem de grandeza, ao "background" regional das áreas mineralizadas do Vale do Ribeira.

A distribuição espacial dos elementos metálicos, associados aos sedimentos lamosos, em especial os distribuídos ao longo da plataforma média, expressa a faixa preferencial de deposição dos sedimentos em suspensão, exportados a partir das áreas continentais para a plataforma sul paulista.

A porção mais a NE da área de estudo, na plataforma média, representa uma ruptura das condições hidrodinâmicas de sedimentação holocênica, expressa pelas diferenças texturais, composicionais e geoquímicas das seqüências sedimentares desta área, com as identificadas ao sul da desembocadura do Rio Ribeira de Iguape.

Esta constatação permite inferir um sentido dominante de deslocamento dos sedimentos finos, na plataforma média sul paulista, no sentido de NE para SE/SW, também indicado pelo incremento das taxas de sedimentação, no sentido sul, obtidas para os testemunhos ao longo da isóbata de 100 metros.

Desta forma, os sedimentos finos, aportados para a plataforma paulista pelas drenagens que se desenvolvem a NE do Rio Ribeira de Iguape, não são diretamente transferidos para as áreas mais ao sul, em função da existência desta ruptura do padrão sedimentar observado a NE da área de estudo. Entretanto, com as informações existentes, não é possível identificar, com precisão, a contribuição atual destas drenagens, para a plataforma sul, por um mecanismo hidrodinâmico de maior escala, atuante ao longo de toda a margem continental. 
Porém, parece seguro indicar a existência de uma atuação preponderante da Corrente do Brasil (CB) no transporte e deposição dos sedimentos da plataforma sul paulista, ao longo do Holoceno superior, semelhante ao identificado por Mahiques et al. (no prelo), para a plataforma norte paulista. Esta influência se caracteriza na atuação da CB sobre a dinâmica sedimentar, com atuação direta sobre a plataforma interna e média, impondo alterações no comportamento das massas de água mais diretamente relacionadas às áreas internas de plataforma, a saber, a Água Costeira, AC e a ascensão da Água Central do Atlântico Sul, ACAS.

A observação de vórtices se deslocando para áreas oceânicas entre as regiões de São Sebastião e Santos, com giro completado por um deslocamento no sentido da plataforma mais rasa, na região entre o litoral sul paulista e norte paranaense, pode representar o mecanismo hidrodinâmico, de média escala, responsável pela transferência da carga em suspensão aportada para o ambiente marinho.

As taxas de sedimentação de escala milenar $\left({ }^{14} \mathrm{C}\right)$ indicam a região mais a sul da plataforma média sul paulista como a área de maior deposição holocênica. Este padrão é também indicado a partir dos valores das taxas de sedimentação secular $\left({ }^{210} \mathrm{~Pb}\right)$, para as áreas mais ao sul da plataforma média.

Muito embora as ordens de grandeza (mm/ano) para as taxas de sedimentação da plataforma sul paulista, tanto obtidas pelo emprego do ${ }^{14} \mathrm{C}$ (taxas milenares), quanto por espectrometria gama (taxas seculares), sejam correlacionáveis às expressas na literatura internacional para diferentes áreas de plataforma continental do mundo, as da plataforma paulista representam valores inferiores às obtidas para plataformas alimentadas atualmente por sistemas de drenagem de porte.

Para a plataforma sul paulista as taxas de sedimentação, em escalas milenar e secular, indicam ter existido, ao longo de todo o Holoceno superior, um significativo e contínuo aporte de sedimentos terrígenos para a área da plataforma média, representativo da conjugação dos mecanismos de dinâmica costeira, condicionados pelos eventos climáticos do Atlântico Sul, conjugados aos efeitos da Corrente do Brasil sobre as massas de água da plataforma continental (AC e 
ACAS), determinantes nos processo de transporte e deposição dos sedimentos em suspensão exportados pelo Sistema continental para a plataforma continental do sul do Estado de São Paulo. 


\section{REFERÊNCIAS BIBLIOGRÁFICAS}

.ALMEIDA, F. F. M. 1964. Fundamentos geológicos do relevo paulista. BOI. I.G.G., (41) : $162-263$

.ALMEIDA, F. F. M. 1976. The system of continental rifts bordering the Santos basin. ANAIS DA ACADEMIA BRASILEIRA DE CIÊNCIAS., 48(supl.): 1526.

.ALMEIDA, F. F. M. \& CARNEIRO, C. D. R. 1998. Origem e evolução da Serra do Mar. REVISTA BRASILEIRA DE GEOCIÊNCIAS, v. 28 (2), p.135-150.

.ARZ, H.W.; PÄTZOLD, J. \& WEFER,G. 1999 a. Climatic changes during the last deglatiation recorded in sediment cores from the northeastern Brazilian Continental margin. GEO MARINE LETTERS, v.19: 209-218.

ARZ, H.W.; PÄTZOLD, J. \& WEFER,G. 1999ㅁ․ The deglatial history of the western tropical Atlantic as inferred from high resolution stable isotope records off northeastern Brazil. EARTH AND PLANETARY SCIENCE LETTERS, V. 167: 105-117.

.BINI, L. M. \& VERA, C. V. M.1995. Padrões espaciais dos conteúdos de nitrogênio total e carbono orgânico do sedimento de fundo da região estuarina de Cananéia (SP). In: SIMPÓSIO DE QUANTIFICAÇÃO EM GEOCIÊNCIAS. Rio Claro, 1995. Resumos expandidos. Rio Claro, UNESP. p. $21-23$.

.BISTRICHI, A. C.; CARNEIRO,C. D. R.; DANTAS, A S. L. 1981. Mapa geológico do Estado de São Paulo - Escala 1:5.000.000. São Paulo, IPT/Divisão de Minas e Geologia Aplicada. 2v.

.BOMTEMPO,V. L. 1993. Hydraulic and sedimentological features of a stretch of the southern coast of the State of the São Paulo (Brazil). In: CONGRESSO BRASILEIRO DE RECURSOS HÍDRICOS, 3. Camboriú,1993. Anais. Camboriú, ABRH. p. 353-361.

.BONETTI FILHO, J. 1995. Transporte de sedimentos por suspensão nas proximidades da Barra de Cananéia - São Paulo. Dissertação de mestrado. Universidade de São Paulo, Instituto Oceanográfico. 2 v.

.BUTLER, L. W. 1970. Shallow structure of the continental margin, southern Brazil and Uruguay. GEOL. SOC. AM. BULL, 81(4): 1079-1096. 
.CAMPANHA, G. A. C. 1991. Tectônica proterozóica no alto e médio Vale do Ribeira, Estados de São Paulo e Paraná. Tese de doutorado. Universidade de São Paulo, Instituto de Geociências. 2v.

.CAMPANHA, G. A. C. ; GIMENEZ FILHO, A. \& ALMEIDA, M. A. 1987. Geologia da Folha Itararé. In: SIMPÓSIO GEOLOGIA DO SUDESTE, 4. Águas de São Pedro, 1995. Resumos. Águas de São Pedro, SBG-Núcleo SP/RJ/ES. p. 111.

.CASTRO FILHO, B. M. ; MIRANDA, L. B. \& MYAO, S. Y. 1987. Condições hidrográficas na plataforma continental ao largo de Ubatuba: variações sazonais e em média escala. BOLM INST. OCEANOGR., S Paulo, 35(2): 135-151.

.CETESB - Companhia de Tecnologia de Saneamento Ambiental. 1991. Avaliação da qualidade ambiental do rio Ribeira de Iguape. Considerações preliminares. Relatório. São Paulo, Cetesb. 54p.

.CETESB - Companhia de Tecnologia de Saneamento Ambiental. 1984/1995. Qualidade das águas interiores do Estado de São Paulo. Relatório. São Paulo, Cetesb. (Volumes editados anualmente, entre 1978 e 1995).

.CHANTON, J. P.;MARTENS,C. S. \& KIPPHUT,G. W. 1983. Lead -210 sediment geochronology in a changing coastal environment. GEOCHIM. COSMOCHIM. ACTA, 47(10): $1791-1804$.

.CHIODI FILHO, C. 1984. Contribuição a geologia das regiões sul paulista e leste paranaense. Grupos Açungui e Setuva. In: CONGRESSO BRASILEIRO DE GEOLOGIA, 33. Rio de Janeiro. 1984. Anais. Rio de Janeiro, SBG. p. 2394-2406.

.CORRÊA, I. C. S. 1978. Morfologia e sedimentologia da plataforma continental entre São Paulo e Santa Catarina. Dissertação de mestrado. Porto Alegre, UFRGS. 147p.

.CORRÊA, I. C. S. 1979. Paleolinhas de costa na plataforma continental entre São Paulo e Santa Catarina. In: SIMPÓSIO REGIONAL DE GEOLOGIA, 2. Rio Claro, 1979. Atas. Rio Claro, SBG, 1:269-278.

.CORREAA, I. C. S.; BAITELLI, R.; SANTOS, H. M. \& ADE, M. V. B. 1989. Sea level change in south-brazilian continental shelf. In: INTERNATIONAL SYMPOSIUM ON GLOBAL CHANGES IN SOUTH AMERICA DURING THE QUATERNARY: PAST-PRESENT-FUTURE. São Paulo, ABEQUA, 1: 245279.

.CORRÊA, I. C. S.; PONZI, V. R. A. \& TRINDADE, L. A. F. 1980. Níveis marinhos quaternários da plataforma continental do Rio de Janeiro. In: CONGRESSO 
BRASILEIRO DE GEOLOGIA, 31. Camboriú, 1980. Anais. Camboriu, SBG, 1: 578-587.

.CORSI, A. C. 1999. Estudo da dispersão de metais pesados em água e sedimentos de corrente a partir de mineralizações de chumbo - zinco prata: o exemplo das jazidas Canoas, Perau e Barrinha (Vale do Ribeira,PR). Dissertação de mestrado. Rio Claro, UNESP/Instituto de Geociências e Ciências Exatas. 139p.

.COSTA, M. P. A.; ALVES, E. C.; PACHECO, P. G. \& MAIA, A. S. 1998. Prováveis estabilizações do nível do mar holocênico em trechos da plataforma continental entre o norte de São Paulo e o sul do Rio de Janeiro, constatadas através de morfologia de detalhe. In: CONGRESSO BRASILEIRO DE GEOLOGIA, 35. Belém, 1998. Anais. Belém, SBG, 2: 436-450.

.CPRM - Companhia de Pesquisa de Recursos Mineirais. 1978. Projeto Geoquímica no Vale do Ribeira. RELATÓRIO FINAL. São Paulo, CPRM. 326p.

.DAITX, E. 1996. Origem e evolução dos depósitos sulfetados tipo-Perau $(\mathrm{Pb}, \mathrm{Zn}, \mathrm{Cu})$, com base nas jazidas Canoas e Perau (Vale do Ribeira,PR). Tese de doutoramento. Rio Claro, UNESP/Instituto de Geociências e Ciências Exatas. 451p.

.DIAS, G.T. de MACEDO. 1996. Classificação de sedimentos marinhos. Proposta de representação em cartas sedimentológicas. In: CONGRESSO BRASILEIRO DE GEOLOGIA, 39. Salvador, 1996. Anais, Salvador, SBG, 3: $423-426$.

.DNPM - Departamento Nacional de Produção Mineral. 1986. Anuário Mineral Brasileiro. Brasília, DNPM. 391p.

.DORNELLES,L.M.A.; LIMA,L.M. \& KÜSEL, E.T. 1998. Heavy metals in the bottom sediments of the continental shelf near Cabo Frio, RJ - Brazil and its association with the texturalfacies. ANAIS DA ACADEMIA BRASILEIRA DE CIÊNCIAS. V.70 (2): 227 - 290.

.EYSINK, G. G.J.; PADUA, H. B. \& BERTOLETTI, S. A. E. P. 1987. Considerações preliminares sobre o nível de contaminação por metais pesados e pesticidas organoclorados no complexo estuarino-lagunar Iguape-Cananéia e Vale do Ribeira. In: SIMPÓSIO SOBRE ECOSSISTEMAS DA COSTA SUL E SUDESTE BRASILEIRA: SÍNTESE DOS CONHECIMENTOS. Cananéia, 1987. Anais. São Paulo, ACIESP, 3: 258 - 266. 
.EYSINK, G. G. J.; PADUA, H. B.: BERTOLETTI, S. A .E. P.;COIMBRA-MARTINS, M.: NAVAS-PEREIRA, D. \& ROBERTO, S. 1988. Metais pesados no Vale do Ribeira e Iguape-Cananéia. AMBIENTE: 2: 6-13.

.EYSINK, G. G. J.; COIMBRA-MARTINS,M.; VARGAS-BOLDRINI,C. \& NAVASPEREIRA, D. 1990. Metais pesados em organismos aquáticos do rio Ribeira de Iguape e do complexo estuarino-lagunar de Iguape-Cananéia: avaliação preliminar. In: SIMPÓSIO DE ECOSSISTEMAS DA COSTA SUL E SUDESTE BRASILEIRA: ESTRUTURA, FUNÇÃO E MANEJO, 2. Águas de Lindóia, 1990. Anais. São Paulo. ACIESP, 2: 417 - 443.

.EYSINK, G. G. J., COIMBRA-MARTINS, M.; VARGAS-BOLDRINI, C. \& NAVASPEREIRA, D. 1991. Avaliação da qualidade ambiental do rio Ribeira de Iguape. Considerações preliminares. São Paulo, Cetesb. 54p.

.FERREIRA, N. L. S. 1994. Aspectos da geoquímica ambiental da mina do Rocha - PR. Dissertação de mestrado. Universidade de São Paulo, Instituto de Geociências. 94p.

.FIGUEIRA, R.C.L;SILVA,L.R.N.;FIGUEIREDO,A.M. \& CUNHA,I.I.L.1997. Análise instrumental de baixos níveis de Césio-137 em amostras marinhas por espectrometria gama. CONFERÊNCIA INTERNACIONAL "GOIANIA - 10 ANOS DEPOIS". Goiânia, 1997.

.FONZAR, B.C. 1994. A circulação atmosférica na América do Sul: os grandes sistemas planetários e subsistemas regionais que atingem o continente: localização e trajetória. CADERNOS DE GEOCIÊNCIAS, IBGE, 11: 11-33.

.FORSTNER, U. 1983. Metal transfer between solid and aqueous phases. In: Metal pollution in the aquatic environment. New York, Springer-Verlag. p. 197-269.

.FÚLFARO, V. J.; SUGUIO, K. \& PONÇANO, W. L. 1974. A gênese das planícies costeiras paulistas. In: CONGRESSO BRASILEIRO DE GEOLOGIA, 28. Porto Alegre, 1974. Anais. Porto Alegre, SBG, 3: 37-42.

.FULLER ,C.C.; van GEEN, A. BASKARAN, M. \& ANIMA,R. 1999. Sediment chronology in San Francisco Bay, California, defined by Pb-210; Th-234; Cs-137 and Pu-239,Pu-240. MARINE CHEMISTRY, 64 (1-2) : 7 - 27. Feb.1999.

.FURTADO,V. V.; BONETTI FILHO, J. \& CONTI, L. A. 1996. Paleo river valley morphology and sea level changes at southeastern brazilian continental shelf. ANAIS DA ACADEMIA BRASILEIRA DE CIÊNCIAS, 68 (Supl. 1): 163-169. 
.FURTADO, V.V. \& MAHIQUES, M.M. de. 1990. Distribuição de sedimentos em regiões costeiras e plataforma continental norte do Estado de São Paulo. In: II SIMPÓSIO SOBRE ECOSSISTEMAS DA COSTA SUL E SUDESTE BRASILEIRA: SÍNTESE DOS CONHECIMENTOS. Águas de Lindóia, Academia de Ciências do Estado de São Paulo. Publicação ACIESP 71-1: 20-29.

.FURTADO, V. V.; MAHIQUES, M. M.; REINHARDT, D.; BONETTI FILHO, J.; FIGUEIREDO JR., A. G. de \& THEILEN, F. 1993. Evidences of sea-level fluctuations in the northern continental shelf of São Paulo State, Brasil. Bremerhaven, Alfred Wegener Institute for Polar and Marine Research. 20p.

.FURTADO, V. V., MAHIQUES, M. M. \& TESSLER, M. G. 1992. Utilização de feições topográficas submersas na correlação de paleoníveis marinhos: uma avaliação. In: CONGRESSO DA ASSOCIAÇÃO BRASILEIRA DE ESTUDOS DO QUATERNÁRIO, 3. Belo Horizonte, 1992. Anais. Belo Horizonte, ABEQUA. P. 175-186.

.GEOBRÁS - Geobrás S/A Engenharia e Fundações. 1966. Complexo Valo Grande, Mar Pequeno e Rio Ribeira de Iguape. Relatório. São Paulo, DAEE. 2v.

.GOFF, J.R.; WHITEHEAD,N.E. \& DITCHBURN, R.G. 1998. Pb ${ }^{210}$ chronology from Wellington Harbour, New Zealand. NEW ZEALAND JOURNAL OF MARINE AND FRESHWATER RESEARCH, v. 32(2): 181 - 186.

.HASUY, Y. 1986. Novo modelo geológico do Vale do Ribeira. Relatório 23.742. São Paulo, SICC/Pró-Minério/IPT. 68p.

.HOSHIKA, A.; SUGUIO, K.; HIRATA, S.; TESSLER, M. G.; MISHIMA, Y. \& MAHIQUES, M. M. de. 1996. Variações decadais nos teores dos elementos metálicos nos sedimentos do estuário santista. In: SIMPÓSIO SOBRE OCEANOGRAFIA, 3. São Paulo, IOUSP, 1996. Resumos. São Paulo, IOUSP. P. 353.

.HUH, CHING-AN \& SU, CHIH-CHIEH. 1999. Sedimentation dynamics ai the East China Sea elucidated from ${ }^{210} \mathrm{~Pb},{ }^{137} \mathrm{Cs}$ and ${ }^{239,240} \mathrm{Pu}$. MARINE GEOLOGY, 160 (1-2): 183 - 196.

INSTITUTO OCEANOGRÁFICO DA USP. Atlas Sedimentológico da plataforma continental do Estado de São Paulo. No prelo. 
.JICA - Japan International Cooperation Agency - Metal Mine Agency of Japan. 1984. REPORT ON GEOLOGICAL SURVEY OF ANTA GORDA - Br. Tokyo, JICA. 79p.

.KUTNER, A. S. 1962. Granulometria dos sedimentos de fundo da região de Cananéia, SP. BOLETIM DA SOCIEDADE BRASILEIRA DE GEOLOGIA,11(2) : $41-54$.

.MACHADO, G.J. 1985. Projeto geoquímica dos sedimentos superficiais da Margem continental brasileira. Relatório final. CPRM / CIRM. 6 volumes.

.MAGLIOCCA , A. \& KUTNER, A. S. 1964. Conteúdo orgânico dos sedimentos de fundo de Cananéia, São Paulo. CONTRIBUIÇÕES INSTITUTO OCEANOGRÁFICO, Univ. S Paulo, série Oceanografia física, (7): 1-15.

MAHIQUES, M. M. de. 1998. Características da matéria orgânica sedimentar da plataforma continental interna e média entre a Baía da Guanabara(RJ) e São Francisco do Sul (SC). Tese de livre docência. Universidade de São Paulo, Instituto Oceanográfico. 86p.

.MAHIQUES, M. M. de. \& FUJIKAWA, L. H. 1995. Calcium carbonate, organic carbon and nitrogen contents, and coarse fraction constituents in the superficial sediments of São Paulo State inner and medium continental shelf. In: LOICZ - LAND OCEAN INTERACTIONS IN THE COASTAL ZONE. São Paulo, 1995. Program and Abstracts. São Paulo, GTB LOICZ/ABEQUA. p. 20-22.

.MAHIQUES,M.M.; MISHIMA, Y. \& RODRIGUES,M. 1999. Characteristics of the sedimentary organic matter in the inner and medium continental shelf between Guanabara Bay and São Francisco do Sul, Southeastern Brazilian Margin. CONTINENTAL SHELF RESEARCH, 19(6): 775-798.

.MAHIQUES, M.M.; SILVEIRA, I.C.A.; SOUSA,S.H.M. \& RODRIGUES,M. PostLGM sedimentation on the outer shelf/ upper slope on the northernmost part of the São paulo brigth, south-eastern, Brazil. No prelo.

.MAHIQUES, M.M. de; TESSLER, M.G. \& FURTADO, V.V. 1998. Energy gradient in enclosed bays, southeastern Brazil. ESTUARINE, COASTAL AND SHELF SCIENCE, 47: 431-446.

.MARTIN, L. \& SUGUIO, K. 1978. Ilha Comprida: um exemplo de ilha-barreira ligado às flutuações do nível marinho durante o Quaternário. In: CONGRESSO BRASILEIRO DE GEOLOGIA, 30. Recife, 1978. Anais. Recife, SBG, 2: 905-912.

.MARTIN, L. \& SUGUIO, K. 1979. Le Quaternaire marin du littoral brésilien entre Cananéia et Barra de Guaratiba (RJ). In: INTERNATIONAL SYMPOSIUM 
ON COASTAL EVOLUTION IN THE QUATERNARY. São Paulo, 1978. Proceedings. São Paulo, IGCP. p. 296-331.

.MORAES, R. P. 1997. Transporte de chumbo e metais associados no Rio Ribeira de Iguape, São Paulo. Dissertação de mestrado. Universidade Estadual de Campinas, Instituto de Geociências. 94p.

.MYAO, S.Y.; NISHIHARA,L. \& SARTI, C.C.1986. carcterísticas físicas e químicas do sistema estuarino-lagunar de Cananéia-Iguape. BOLETIM DI INSTITUTO OCEANOGRÁFICO, 34: 23-36.

.NOLLER, J.S. 2000. Lead - 210 Geochronology. In: QUATERNARY GEOCHRONOLOGY METHODS AND APPLICATIONS. Jay Stratton Noller, Janet M. Sowers \& William R. Lettis (editors). p.115 a 120.

.PARFENOV,Y.D. 1974. Polonium-210 in the environment and in the human organism. AT. Energy REVT., v.12: 75-143.

.PATCHINEELAM,S.R. \& SMOAK, J.M. 1999. Sediment accumulation rates along the inner eastern Brazilian continental shelf. GEO MARINE LETTERS, 19: 196-201.

.PETRI, S. \& SUGUIO, K. 1971. Some aspects on the Neocenozoic sedimentation in the Cananéia - Iguape lagoonal region, São Paulo, Brazil. ESTUDOS SEDIMENTOLÓGICOS, 1(1): 25-33.

.PETRI, S. \& SUGUIO, K. 1973. Stratigraphy of the Iguape-Cananéia lagoonal region sedimentary deposits, São Paulo, Brazil. Part II: Heavy minerals studies, micro-organisms inventories and stratigraphical interpretations. BOLETIM IG-USP, 4: $7-85$.

.PRESSINOTTI, W. L. \& PRESSINOTTI, M. M. M. 1980. Contribuição à geologia dos arredores de Registro, SP. REVISTA IG, 1(2): 5-24.

.REMAC - Projeto de Reconhecimento Global da Margem Continental Brasileira. 1979. Rio de Janeiro, Petrobrás. Projeto REMAC, 11: coleção de mapas.

.RICCOMINI, C.; TESSLER, M. G. \& SUGUIO, K. 1987. Novas evidências de atividade tectônica moderna no sudeste brasileiro: os depósitos falhados da formação Pariquera-Açu. In: GCP PROJECT 201. Merida, 1987. Publicação especial. São Paulo, ABEQUA, 2: 29-42.

.RODRIGUES, M. 1996. Sedimentação atual nas enseadas de Ubatumirim, Picinguaba e plataforma interna adjacente, Ubatuba, Estado de São Paulo. Dissertação de mestrado. Instituto Oceanográfico da Universidade de São Paulo. 158p. 
.SAITO, R. T. 1996. Determinação de ${ }^{210} \mathrm{~Pb}$ e ${ }^{210} \mathrm{Po}$ em amostras marinhas e aerossóis. Dissertação de mestrado. São Paulo, IPEN/CNEN-SP.

.SAITO, R. T.; CUNHA, I. I. L.; FIGUEIRA, R. C. L. \& TESSLER, M. G. 1999. Determinação de ${ }^{210} \mathrm{~Pb}$ e ${ }^{226} \mathrm{Ra}$ por espectrômetria gama em sedimentos marinhos do litoral sul de São Paulo. In: CONGRESSO GERAL DE ENERGIA NUCLEAR. Poços de Caldas, 1999.

.SAITO, R. T; CUNHA, I. I. L. \& TESSLER, M. G. 1997. Uso de traçador radioativo de $210 \mathrm{~Pb}$ para determinar taxas de sedimentação. In: CONGRESSO LATINO AMERICANO SOBRE CIÊNCIAS DO MAR, 7. Santos, 1997. Resumos expandidos. São Paulo, IOUSP/ALICMAR/FIESP, 2: 379-380.

.SCHAEFFER-NOVELLI, Y.; MESQUITA, H.S.L. \& CINTRÖN-MOLERO,G. 1990. The Cananéia lagoon estuarine system, São Paulo, Brazil. ESTUARIES, 13(2): 193-203.

.SHEPARD,F. P. 1954. Nomenclature based on sand-silt clay ratios. JOURNAL OF SEDIMENTARY PETROLOGY, 24(3): 151-158.

.SILVA, R. H. P. 1997. Geoquímica e impacto ambiental do arsênio no Vale do Ribeira (SP-PR). Dissertação de mestrado. Universidade Estadual de Campinas, Instituto de Geociências. 100p.

.SMITH, J. N. \& BEWERS, J. M. 1983. Radionuclides in the marine environment uses and concerns. CANADIAN. CHEOCHIMICAL. New. October: 23 -25.

.SOMAYAJULU,B.L.K.; BHUSHAN,R.; SAKAR,A.; BURR,G.S. \& JULL,A.J.T.1999. Sediment deposition rates on the continental margins of the eastern Arabian sea using $210 \mathrm{~Pb}, 137 \mathrm{Cs}$ and $14 \mathrm{C}$. THE SCIENCE OF THE TOTAL ENVIRONMENT. 237/238: 429-439.

.SOMMERFIELD,C.K. \& NITTROUER,C.A. 1999. Modern accumulation rate and a sediment budget for the Eel shelf: a flood-dominated depositional environment. MARINE GEOLOGY, 154: 227-241.

.SOUZA, L. A. P. 1995. A planície costeira Cananéia-Iguape, litoral sul do Estado de São Paulo: um exemplo de utilização de métodos geofísicos no estudo de áreas costeiras. Dissertação de mestrado. Universidade de São Paulo, Instituto Oceanográfico. 207p.

.SOUZA, L. A. P.; TESSLER, M. G. \& GALLI, V. L. 1996. O Gráben de Cananéia. REVISTA BRASILEIRA DE GEOCIÊNCIAS, 26(3): 139-150.

.SUGUIO,K. 1999. Geologia do Quaternário e mudanças ambientais (Presente + Passado = Futuro?). Comunicações e Artes gráficas, 1999. São Paulo, 366p. 
.SUGUIO, K. \& MARTIN,L. 1978. Formações quaternárias marinhas do litoral paulista e sul fluminense. In: INTERNATIONAL SYMPOSIUM ON COASTAL EVOLUTION IN THE QUATERNARY.São Paulo, 1978. Special publication $\mathrm{n}^{\circ} 1$. The Brazilian National Working Group for the IGCP, Project 61/Instituto de Geociências USP/ Sociedade Brasileira de Geologia. 55p.

.TASSSINARI,C.C.G.; BARBOUR,A.P.; DAITX,E.C. \& SATO,K. 1990. Aplicação de isótopos de $\mathrm{Pb}$ e $\mathrm{Sr}$ na determinação da natureza das fontes das mineralizações de chumbo do Vale do Ribeira, SP e Pr. CONGRESSO BRASILEIRO DE GEOLOGIA,34, Natal, 1990. Anais. SBG, v.3: 1254-1266.

.TEISSEDRE, J. M; LOPES, M. F. C.; SANCHES, J. L. \& SILVA, W. F. 1981. Contribuição da hidrogeologia ao conhecimento do litoral paulista. In: SIMPÓSIO REGIONAL DE GEOLOGIA, 3. Curitiba, 1981. Atas. Curitiba, SBG, 1: 369-380.

.TESSLER, M. G. 1982. Sedimentação atual na região lagunar de Cananéia Iguape, Estado de São Paulo. Dissertação de Mestrado. Universidade de São Paulo, Instituto de Geociências. 2 v.

.TESSLER, M. G. 1988. Dinâmica sedimentar quaternária no litoral sul paulista: Tese de doutorado. Universidade de São Paulo, Instituto de Geociências. $276 p$.

.TESSLER, M. G.; SUGUIO, K. \& ROBILOTTA, P. R. 1987. Teores de alguns elementos traços metálicos em sedimentos pelíticos da superfície de fundo da região lagunar de Cananéia - Iguape. In: SIMPÓSIO SOBRE ECOSSISTEMAS DA COSTA SUL E SUDESTE BRASILEIRA: SÍNTESE DOS CONHECIMENTOS. Cananéia, 1987. Anais. São Paulo, ACIESP, 2: 255-263.

.TESSLER, M. G. \& SOUZA, L. A. P. 1998. Dinâmica sedimentar e feições sedimentares identificadas na superfície de fundo do sistema Cananéia Iguape, SP. Revista Brasileira de Oceanografia, 46 (1): 69-83.

.TRUMBORE,S.E.2000. Radiocarbon geocronology. In: QUATERNARY GEOCHRONOLOGY METHODS AND APPLICATIONS. Jay Stratton Noller, Janet M. Sowers \& William R. Lettis (editors). p.41-60.

.ZEMBRUSCKI, S. G. 1979. Geomorfologia da margem continental sul brasileira e das bacias oceânicas adjacentes. Projeto REMAC, 7: 129-177. 
TABELAS 


\begin{tabular}{|c|c|c|c|c|}
\hline $\begin{array}{l}\text { Est no } \\
\text { Besnard }\end{array}$ & Latitude (S) & Longitude(W) & Prof.(m) & R. (cm) \\
\hline 6651 & $25^{\circ} 53.58^{\circ}$ & $045^{\circ} 42.13^{\prime}$ & 256 & 31,5 \\
\hline 6652 & $25^{\circ} 51.04^{\prime}$ & $045^{\circ} 47.30^{\circ}$ & 206 & 36 \\
\hline 6653 & $25^{\circ} 43.50^{\prime}$ & $046^{\circ} 02.50^{\prime}$ & 155 & 24,5 \\
\hline 6654 & $25^{\circ} 28.20^{\prime}$ & $046^{\circ} 34.50^{\circ}$ & 90 & 38 \\
\hline 6655 & $25^{\circ} 26.88^{\circ}$ & $046^{\circ} 38.85^{\prime}$ & 80 & 41 \\
\hline 6657 & $25^{\circ} 17.30^{\circ}$ & $046^{\circ} 55.60^{\circ}$ & 60 & 25 \\
\hline 6658 & $25^{\circ} 11.89^{\circ}$ & $046^{\circ} 08.09^{\prime}$ & 50 & 10 \\
\hline 6678 & $24^{\circ} 46.36^{\prime}$ & $045^{\circ} 11.13^{\circ}$ & 100 & 20 \\
\hline 6683 & $25^{\circ} 03.71^{\circ}$ & $045^{\circ} 33.41^{\circ}$ & 100 & 46 \\
\hline 6692 & $25^{\circ} 50.63^{\prime}$ & $046^{\circ} 57.02^{\prime}$ & 100 & 55 \\
\hline 6696 & $25^{\circ} 34.15^{\prime}$ & $046^{\circ} 41.38^{\prime}$ & 92 & 52 \\
\hline 6700 & $25^{\circ} 24.91^{\circ}$ & $046^{\circ} 22.33^{\prime}$ & 100 & 40 \\
\hline 6704 & $25^{\circ} 14.56^{\circ}$ & $046^{\circ} 03.01^{\circ}$ & 97 & 52 \\
\hline
\end{tabular}

Tabela 1. Posicionamento das estações de coleta. 


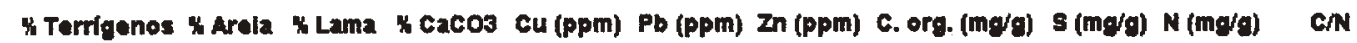
Testemunho 665

\begin{tabular}{|c|c|c|c|c|c|c|c|c|c|c|c|}
\hline $0-2$ & & & & & 4 & 22 & 34 & 4,6821 & 0,1455 & 0,5515 & 8,49 \\
\hline $2-4$ & 71,1 & 34,1 & 16,9 & 28,9 & 2 & 8 & 32 & 4,3100 & 0,1615 & 0,5154 & 8,37 \\
\hline $4-6$ & 72.6 & 39.6 & 33,0 & 27,4 & 2 & 11 & 35 & 3,5909 & 0,1491 & 0,4991 & 8,29 \\
\hline $6-8$ & 73,6 & 41,9 & 31.7 & 26,4 & 2 & 10 & 34 & 3,1881 & 0,1122 & 0,4077 & 7,82 \\
\hline $8-10$ & 73,3 & 44,4 & 28,8 & 26.7 & 2 & 7 & 33 & 3,4290 & 0,1079 & 0,3622 & 9,47 \\
\hline $10-12$ & 72,2 & 43,2 & 29,0 & 27.8 & 2 & $B$ & 32 & 3,1076 & 0,1134 & 0,3301 & 9,41 \\
\hline $12-14$ & 72,3 & 37,9 & 34,4 & 27,7 & 2 & 7 & 34 & 3,3171 & 0,1497 & 0,3584 & 9,26 \\
\hline $14-16$ & 72,0 & 40,0 & 32,0 & 28,0 & 2 & 6 & 33 & 3,0397 & 0,1534 & 0,3235 & 9,4 \\
\hline $16-18$ & 72,0 & 38,5 & 33,5 & 28.0 & 2 & 10 & 33 & 2,9046 & 0,1605 & 0,1972 & 14,73 \\
\hline $18-20$ & 72.1 & 40,2 & 31,9 & 27,9 & 2 & 7 & 31 & 2,7966 & 0,2790 & 0,4912 & 5,69 \\
\hline $20-22$ & 69,3 & 35,1 & 34,2 & 30,7 & 2 & 5 & 30 & 2,9945 & 0.3151 & 0,5310 & 5,64 \\
\hline $22-24$ & 72,6 & 39,1 & 33,5 & 27,4 & 1 & 7 & 26 & 3,0216 & 0,3604 & 0,4932 & 6.13 \\
\hline $24-26$ & 73.7 & 43,9 & 29,8 & 26,3 & 1 & 5 & 25 & 2,4562 & 0,2934 & 0.4999 & 8,37 \\
\hline $26-28$ & 73,6 & 38,8 & 34,8 & 26,4 & 1 & 6 & 28 & 2,6551 & 0,3626 & 0.4389 & 6,05 \\
\hline $28-31$ & 72,8 & 42,8 & 30,0 & 27,2 & 2 & 8 & 31 & 2,7710 & 0,4805 & 0,4860 & 5.71 \\
\hline \multicolumn{12}{|c|}{ Testemunhe 6652} \\
\hline $0-2$ & 51,1 & 27,2 & 23,9 & 48,9 & 2 & 8 & 41 & 5,2658 & 0,1393 & 0,7221 & 7,29 \\
\hline $2-4$ & 51.1 & 22,6 & 28,5 & 48,9 & 2 & 11 & 40 & 4,3177 & 0,1139 & 0.5214 & 8.28 \\
\hline $4-6$ & 49,9 & 22,0 & 27,9 & 50.1 & 2 & 7 & 40 & 4,4296 & 0.1444 & 0.5787 & 7.65 \\
\hline $6-8$ & 49.7 & 24,6 & 25,1 & 50,3 & 1 & 7 & 35 & 4,3611 & 0.1376 & 0,6164 & 7.08 \\
\hline $8-10$ & 51,1 & 26,2 & 24,9 & 48,9 & 1 & 6 & 36 & 3,2080 & 0,1120 & 0,4788 & 6,70 \\
\hline $10-12$ & 48,4 & 23,8 & 24,6 & 51,6 & 1 & 6 & 36 & 3,2485 & 0.1067 & 0.3982 & 8.16 \\
\hline $12-14$ & 47.6 & 22,6 & 25,0 & 52,4 & 1 & 5 & 35 & 3,1746 & 0,1133 & 0,4723 & 6.72 \\
\hline $14-16$ & 46,9 & 22,0 & 24,9 & 53,1 & 1 & 5 & 35 & 2,9087 & 0,1233 & 0,4144 & 7.02 \\
\hline $16-18$ & 49,5 & 23,6 & 25,9 & 50,5 & -1 & 4 & 31 & 3,0967 & 0,1341 & 0,4350 & 7,12 \\
\hline $18-20$ & 48,7 & 23,6 & 25,1 & 51,3 & -1 & 4 & 31 & 3,4166 & 0,1477 & 0,3595 & 9.50 \\
\hline $20-22$ & 46,7 & 20,0 & 26,7 & 53,3 & -1 & 5 & 32 & 3,5257 & 0,2265 & 0,5093 & 6,92 \\
\hline $22-24$ & 49,2 & 22,8 & 26,4 & 50,8 & -1 & 4 & 31 & 3,5526 & 0,2963 & 0,4720 & 7,53 \\
\hline $24-26$ & 49,2 & 24,0 & 25,2 & 50,8 & -1 & 6 & 34 & 3,3434 & 0,2937 & 0,4347 & 7,69 \\
\hline $26-28$ & 49,9 & 23,2 & 26,7 & 50.1 & -1 & 5 & 33 & 3,1474 & 0,3617 & 0,4033 & 7,80 \\
\hline $28-30$ & 48,5 & 23,6 & 24,9 & 51,5 & 1 & 5 & 35 & 3,3291 & 0,4159 & 0,4125 & 8,07 \\
\hline $30-32$ & 50.7 & 24,0 & 26,7 & 49,3 & 1 & 7 & 34 & 3,6121 & 0,4384 & 0,4495 & 8,24 \\
\hline $32-36$ & 47,7 & 22,0 & 25.7 & 52,3 & 1 & 5 & 33 & 3,8064 & 0,5857 & 0,4786 & 7.95 \\
\hline \multicolumn{12}{|c|}{ Testemunho 6603} \\
\hline $0-2$ & 43.1 & 8,6 & 34,5 & 56.9 & 4 & 10 & 45 & 6,7610 & 0,1796 & 0,9087 & 7.44 \\
\hline $2+4$ & 46,1 & 10,0 & 36,1 & 59.9 & 4 & 12 & 43 & 7,1069 & 0,1697 & 0,9131 & 7,78 \\
\hline $4-6$ & 38,7 & 7,6 & 31,1 & 61,3 & 4 & 10 & 39 & 6,6710 & 0,1720 & 0,8356 & 7,98 \\
\hline $6-8$ & 37,3 & 7,8 & 29,5 & 62.7 & 3 & 8 & 38 & 6,3401 & 0,1920 & 0,8172 & 7,76 \\
\hline $8-10$ & 42,5 & 10,0 & 32,5 & 57.5 & 2 & 8 & 29 & 6,2531 & 0,1447 & 0,8127 & 7,69 \\
\hline $10-12$ & 36,6 & 6,4 & 30,2 & 63,4 & 2 & 8 & 31 & 5,4294 & 0,1329 & 0,7119 & 7,63 \\
\hline $12-14$ & 34,2 & 7.4 & 26,8 & 65,8 & 1 & 8 & 30 & 4,4813 & 0,1570 & 0,4541 & 9,87 \\
\hline $14-16$ & 42,9 & 8,2 & 34.7 & 57.1 & 2 & 8 & 32 & 6,1293 & 0,1693 & 0,6625 & 9,25 \\
\hline $16-18$ & 45,3 & 8,0 & 37,3 & 54,7 & 3 & 8 & 35 & 6,1298 & 0,1703 & 0,6944 & 8,83 \\
\hline $18-20$ & 41,3 & 8,6 & 32.7 & 58.7 & 2 & 7 & 35 & 3,5790 & 0,1402 & 0,2822 & 12,68 \\
\hline $20-22$ & 38,4 & 8,8 & 29.6 & 61.6 & 2 & 9 & 31 & 5,8122 & 0.1951 & 0,4833 & 12,03 \\
\hline $22-24$ & 36,4 & 8.2 & 28,2 & 63,6 & 2 & 6 & 32 & 4,3883 & 0.1775 & 0,3452 & 12,71 \\
\hline \multicolumn{12}{|c|}{ Testemunho 6854} \\
\hline $0-2$ & & & & & 5 & 19 & 51 & 14,9410 & 0,5903 & 1,6907 & 8.84 \\
\hline $2-4$ & 77.4 & 36,4 & 41,0 & 22,6 & 6 & 19 & 51 & 14,1014 & 0,6399 & 1,5726 & 8,97 \\
\hline $4-6$ & 75.5 & 35,7 & 39,8 & 24,5 & 6 & 17 & 53 & 14,2501 & 0,5031 & 1,4254 & 10,00 \\
\hline 6.8 & 71.1 & 37.2 & 39,9 & 22,9 & 6 & 17 & 59 & 13,8464 & 0,5533 & 1,9965 & 9,92 \\
\hline $8-10$ & 78,2 & 38.1 & 40,1 & 21,8 & 7 & 18 & 68 & 13,9219 & 0,6184 & 1,4329 & 9.72 \\
\hline $10-12$ & 76.3 & 34,1 & 42,2 & 23.7 & 7 & 17 & 68 & 13,2646 & 0,9707 & 1,2876 & 10,30 \\
\hline $12-14$ & 76,4 & 32,9 & 43.5 & 23,6 & 7 & 16 & 65 & 14,9340 & 1,3412 & 1,2869 & 11,60 \\
\hline $14-16$ & 77.0 & 35,6 & 41,4 & 23,0 & 7 & 17 & 69 & 13,5391 & 1,8966 & 1,2221 & 11,07 \\
\hline $16-18$ & 77.6 & 32,0 & 45,6 & 22,4 & 8 & 18 & 73 & 13,0895 & 2,2397 & 1.1172 & 11,72 \\
\hline $18-20$ & 76.0 & 35,8 & 40,2 & 24,0 & 8 & 18 & 72 & 12,4526 & 2,5318 & 1,1913 & 10,45 \\
\hline $20-22$ & 77.4 & 27,4 & 50,0 & 22,6 & 7 & 16 & 69 & 12,6091 & 2,8358 & 1,1880 & 10,61 \\
\hline $22-24$ & 78.4 & 25,4 & 53,0 & 21,6 & 7 & 16 & 69 & 12,9172 & 2,3675 & 1.1657 & 11,08 \\
\hline $24-26$ & 77.6 & 25,3 & 52,3 & 22,4 & 4 & 13 & 45 & 12,7134 & 2,6833 & 1,2122 & 10,49 \\
\hline $26-28$ & 78.4 & 33,0 & 45,4 & 21,6 & 5 & 15 & 52 & 12,6342 & 2,7454 & 1.1148 & 11,33 \\
\hline $28-30$ & 78,6 & 26,2 & 52,4 & 21,4 & 5 & 15 & 58 & 11,9943 & 3,1667 & 1,0626 & 11,29 \\
\hline $30-32$ & 76,7 & 21,0 & 55,6 & 23,3 & 7 & 17 & 64 & 11,9545 & 2,8580 & 1,0033 & 11,92 \\
\hline $32-34$ & 78,0 & 23,7 & 54,3 & 22,0 & 6 & 16 & 62 & 11,9924 & 3,0670 & 1,0174 & 11,79 \\
\hline $34-36$ & 78,4 & 25.7 & 52.7 & 21,6 & 6 & 15 & 62 & 11,2502 & 3,3826 & 0,9894 & 11,37 \\
\hline $36-38$ & 78.6 & 33,6 & 45,0 & 21,4 & 6 & 14 & 66 & 11,6528 & 3,4495 & 1,0726 & 10,86 \\
\hline
\end{tabular}




\begin{tabular}{|c|c|c|c|c|c|c|c|c|c|c|c|}
\hline $0-2$ & 75,5 & 17,8 & 57.6 & 24,6 & 7 & 17 & 65 & 12,4508 & 0,5499 & 1,2429 & 10,02 \\
\hline $2-4$ & 77,2 & 18,6 & 58,6 & 22,8 & 7 & 17 & 64 & 12,3931 & 0,5242 & 1,2127 & 10.22 \\
\hline $4-6$ & 78,0 & 20,8 & 57.2 & 22,0 & 6 & 16 & 61 & 11,7458 & 0,7523 & 1,1631 & 10,10 \\
\hline $6-8$ & 78,2 & 24,0 & 54,2 & 21,8 & 6 & 16 & 60 & 11,8425 & 0,8394 & 1,1099 & 10,67 \\
\hline $8-10$ & 78,4 & 19,6 & 58,8 & 21,6 & 17 & 18 & 67 & 12,1957 & 1,0043 & 1,1397 & 10,70 \\
\hline $10-12$ & 77.8 & 18,2 & 59,6 & 22,2 & 18 & 20 & 72 & 13,0034 & 1,7356 & 1,1944 & 10,89 \\
\hline $12-14$ & 77.8 & 24,0 & 53,8 & 22,2 & 18 & 19 & 74 & 12,2265 & 1.6721 & 1,0845 & 11,27 \\
\hline $14-16$ & 78,2 & 19,6 & 58,6 & 21,8 & 17 & 19 & 72 & 10.9394 & 2,1743 & 0,9966 & 10,95 \\
\hline $16-18$ & 77,4 & 18,6 & 58,8 & 22,6 & 17 & 21 & 74 & 10,8067 & 2,1859 & 1.0252 & 10,54 \\
\hline $18-20$ & 77,8 & 21,2 & 56,6 & 22,2 & 17 & 19 & 73 & 11,1459 & 2,1606 & 1,0200 & 10,93 \\
\hline $20-22$ & 76.6 & 22.7 & 55,9 & 21,4 & 16 & 16 & 70 & 10,9057 & $2,259 \theta$ & 0,9665 & 11,28 \\
\hline $22-24$ & 78,0 & 18,6 & 59,4 & 22,0 & 16 & 14 & 70 & 10,9545 & 2,5481 & 0,9973 & 10,96 \\
\hline $24-26$ & 78,2 & 19.8 & 58,4 & 21,8 & 15 & 19 & 68 & 11,0420 & 2,5398 & 0,9836 & 11,27 \\
\hline $26-28$ & 70,0 & 19,6 & 58,4 & 22,0 & 15 & 16 & 67 & 10,6458 & 2,4740 & 0,9338 & 11,40 \\
\hline $28-30$ & 77,6 & 18,4 & 59,2 & 22,4 & 16 & 22 & 71 & 11,8738 & 2,5569 & 1,0608 & 11,19 \\
\hline $30-32$ & 78,0 & 16,6 & 61,4 & 22,0 & 19 & 20 & 79 & 11,2609 & 3,2038 & 0,9721 & 11,58 \\
\hline $32-34$ & 77,6 & 20,4 & 57,2 & 22,4 & 17 & 16 & 62 & 10,4435 & 3,0229 & 0,8323 & 12,55 \\
\hline $34-36$ & 78,0 & 23,6 & 54,4 & 22,0 & 18 & 16 & 68 & 12,2886 & 2,8883 & 1,8422 & 8,67 \\
\hline $36-38$ & 78,2 & 22,0 & 58,2 & 21.8 & 18 & 13 & 68 & 11,0503 & 2,4478 & 1,0875 & 10,16 \\
\hline $38-40$ & 79,2 & 20,8 & 53,8 & 20,8 & 17 & 12 & 68 & 10,2608 & 2,6098 & 0,9583 & 10,71 \\
\hline \multicolumn{12}{|c|}{ Testemunho eser } \\
\hline $0-2$ & 82,4 & 64,1 & 18,3 & 97,6 & 9 & 7 & 29 & 4,7123 & 0,1526 & 0,3987 & 11,82 \\
\hline $2-4$ & 80,8 & 59,9 & 20,9 & 19,2 & 9 & 7 & 34 & 6,0625 & 0,1794 & 0,5323 & 11,39 \\
\hline $4-6$ & 77,6 & 57.7 & 19,9 & 22.4 & 10 & 7 & 30 & 5,5340 & 0,1846 & 0,5243 & 10,56 \\
\hline $6-8$ & 76,4 & 59,8 & 16,6 & 23,6 & 10 & 8 & 29 & 4,6104 & 0,1969 & 0,3797 & 12,34 \\
\hline $8-10$ & 78,4 & 64,9 & 13,5 & 21,6 & 10 & 6 & 24 & 4,0135 & 0,2442 & 0,2930 & 13,70 \\
\hline $10-12$ & 76,6 & 65.9 & 12.7 & 21,4 & 8 & 5 & 23 & 3,9325 & 0,2826 & 0,2681 & 14,67 \\
\hline $12-14$ & 81,0 & 65.9 & 15.1 & 19.0 & 9 & 2 & 24 & 4,0969 & 0,5101 & 0,3009 & 13,42 \\
\hline $14-16$ & 81,6 & 66,1 & 15,5 & 18,4 & 9 & 6 & 23 & 3,5898 & 0,5828 & 0,3065 & 11,69 \\
\hline $16-18$ & 70,4 & 63,6 & 14,6 & 21,6 & 10 & 6 & 24 & 3,7357 & 0,6208 & 0,3189 & 11,71 \\
\hline $18-20$ & 81,0 & 64,5 & 16,5 & 19,0 & 9 & 5 & 22 & 3,5923 & 0,7615 & 0,8620 & 12,34 \\
\hline $20-22$ & 80,2 & 63,3 & 18,9 & 19,8 & 10 & 6 & 26 & 4,2442 & 0,9049 & 0,3777 & 11,24 \\
\hline $22-24$ & 78.2 & 60,5 & 17.7 & 21,8 & 9 & 6 & 26 & 5,0795 & 0,8157 & 0,4163 & 12,19 \\
\hline $24-26$ & 81,4 & 64.7 & 16.7 & 18,6 & 9 & 4 & 24 & 4,7061 & 0,8038 & 0,3385 & 13,90 \\
\hline \multicolumn{12}{|c|}{ ITestemunho 6968} \\
\hline $0-2$ & - & - & - & - & B & 13 & 22 & 3,5145 & 0,1747 & 0,1996 & 17.61 \\
\hline $2-4$ & 80,0 & 72,0 & 8,0 & 20,0 & 8 & 4 & 20 & 2,7907 & 0,1668 & 0,1615 & 17,28 \\
\hline $4-6$ & 73,1 & 66,9 & 6.2 & 26.9 & 7 & 4 & 20 & 2,5685 & 0,2326 & 0,1507 & 17,04 \\
\hline \multicolumn{11}{|c|}{ Testemunho 6878} & 15,98 \\
\hline $0-2$ & 40,0 & 13,8 & 26,2 & 60,0 & 12 & -2 & 34 & 9,1510 & 0,2233 & 0,7918 & 11,56 \\
\hline $2-4$ & 29,3 & 10,2 & 19.2 & 70.7 & 12 & -2 & 30 & 7,3211 & 0,1769 & 0,6086 & 12,03 \\
\hline $4-6$ & 36.7 & 14,4 & 22,4 & 63,3 & 14 & -2 & 26 & 7,0581 & 0,1445 & 0,5345 & 13,20 \\
\hline $6-8$ & 34.7 & 13,4 & 21.4 & 65.3 & 13 & -2 & 28 & 5,5630 & 0,1263 & 0,4131 & 13,47 \\
\hline $8-10$ & 34.1 & 12,2 & 22,0 & 65,9 & 15 & -2 & 41 & 7,5024 & 0,2079 & 0,6302 & 11,90 \\
\hline $10-12$ & 34,5 & 13,8 & 20,8 & 65,5 & 13 & -2 & 33 & 6,3542 & 0,1890 & 0,5965 & 11,84 \\
\hline $12-14$ & 42,0 & 15.0 & 27,0 & 58,0 & 12 & -2 & 33 & 7,5083 & 0,3215 & 0,6220 & 12,07 \\
\hline $14-16$ & 46.8 & 12,4 & 34,4 & 59.2 & 11 & -2 & 32 & 8,0814 & 0,6152 & 0,6498 & 12,55 \\
\hline $16 \cdot 18$ & 33,4 & 10,0 & 23,4 & 66,6 & 9 & -2 & 26 & 7,7975 & 0,6424 & 0,6450 & 12,09 \\
\hline $18-20$ & 35,4 & 11,8 & 23,6 & 64,6 & 11 & -2 & 30 & 5,9768 & 0,6874 & 0,4457 & 13,41 \\
\hline \multicolumn{12}{|c|}{ Testemunhe 6883} \\
\hline $0-2$ & - & - & - & - & 22 & 36 & 82 & 18,8712 & 0,6716 & 1,9824 & 9,52 \\
\hline $2-4$ & - & - & - & - & 22 & 22 & $\theta 1$ & 18,4957 & 0,5883 & 2,0655 & 8,95 \\
\hline $4-6$ & 70,7 & 2,6 & 68,1 & 29,3 & 20 & 14 & 73 & 16,1054 & 0,5470 & 1,9520 & 8,25 \\
\hline $6-8$ & 67,3 & 2,4 & 64,9 & 32,7 & 24 & 10 & 66 & 14,9424 & 0,5287 & 1,8149 & 0,23 \\
\hline$\theta-10$ & 70.7 & 2,0 & 68,7 & 29,3 & 27 & 11 & 85 & 16,2498 & 0,6915 & 1,8509 & 8,78 \\
\hline $10-12$ & 71,8 & 1,6 & 70,3 & 28,1 & 26 & 20 & 84 & 16,2270 & 0,7575 & 1,8234 & 8,90 \\
\hline $12-14$ & 71,6 & 4,4 & 67.2 & 28,4 & 20 & 22 & 78 & 15,7945 & 0,9702 & 1,8209 & 8,67 \\
\hline $14-16$ & 71.8 & 2,4 & 69,4 & 28,2 & 20 & 17 & 75 & 15,1789 & 1,2133 & 1,7589 & 8,63 \\
\hline $16-18$ & 71,5 & 1,4 & 70,1 & 28,5 & 26 & 15 & 71 & 15,5249 & 1,2762 & 1,6938 & 9,16 \\
\hline $18-20$ & 17.5 & 3,2 & 68,3 & 28,5 & 18 & 16 & 73 & 15,5264 & 1,3747 & 1,6777 & 9,25 \\
\hline $20-22$ & 71,8 & 3,0 & 68,8 & 28,2 & 20 & 16 & 73 & 14,1208 & 1,5444 & 1,6940 & 8,93 \\
\hline $22-24$ & 71,0 & 5.4 & 65.7 & 28,9 & 19 & 7 & 69 & 13,1799 & 2,3218 & 1,5264 & 8,63 \\
\hline $24-26$ & 69,1 & 4.8 & 64,3 & 30,9 & 21 & $\theta$ & 67 & 14,4216 & 2,8916 & 1,5232 & 9.47 \\
\hline $26-28$ & 71,3 & 3,6 & 67,7 & 28,7 & 21 & 10 & 65 & 13,9456 & 2,7681 & 1,5621 & 8,93 \\
\hline $28-30$ & 72.0 & 6,0 & 66,1 & 27,9 & 20 & 10 & 57 & 14,7060 & 2,5453 & 1.5998 & 9.19 \\
\hline $30-32$ & 70,9 & 5,2 & 65.7 & 29,1 & 22 & 9 & 77 & 14,4476 & 2,6171 & 1,6491 & 0,76 \\
\hline $32-34$ & 71,6 & 6,6 & 65,0 & 28,4 & 21 & 11 & 75 & - & - & - & - \\
\hline $34-36$ & 71,3 & 7,0 & 64,3 & 28.7 & 19 & 14 & 79 & 14,0959 & 3,3834 & 1,5349 & 9,19 \\
\hline $36-38$ & 71.9 & 5,0 & 66,9 & 28,1 & 18 & 5 & 71 & 13,2461 & 3,3043 & 1.4563 & 9,09 \\
\hline $38-40$ & 72,0 & 8,2 & 63,8 & 28,0 & 17 & 4 & 67 & 14,3967 & 3,9212 & 1.4316 & 10,05 \\
\hline $40-42$ & 72,4 & 6,6 & 65,9 & 27,5 & 21 & 7 & 74 & 15,0099 & 3,9578 & 1.5127 & 9,92 \\
\hline $42-46$ & 72.4 & 6,6 & 65,9 & 27.5 & 22 & 4 & 69 & 13,9062 & 3,9120 & 1,4892 & 9,34 \\
\hline
\end{tabular}




\begin{tabular}{|c|c|c|c|c|c|c|c|c|c|c|c|}
\hline \multicolumn{12}{|c|}{ Testemunhe 6692} \\
\hline $0-2$ & 82,8 & 0,2 & 82,6 & 17,2 & 21 & 23 & 78 & 16,8251 & 0,5983 & 1,7433 & 9,65 \\
\hline $2-4$ & 83,4 & 0,6 & 82,8 & 16,6 & 21 & 19 & 76 & 15,4408 & 0,6731 & 1,7942 & 8,61 \\
\hline $4-6$ & 82,8 & 0.4 & 82,4 & 17,2 & 22 & 23 & 78 & 15,2887 & 0,4735 & 1,9411 & 7,80 \\
\hline $6-8$ & 82,6 & 0.6 & 82,0 & 17,4 & 22 & 19 & 75 & 14.7173 & 0,7204 & 1,9045 & 7,73 \\
\hline $8-10$ & 83,0 & 0.4 & 82,6 & 17,0 & 21 & 18 & 74 & 14,6230 & 0,8427 & 1,0594 & 7,86 \\
\hline $10-12$ & 82,6 & 0,4 & 82,2 & 17,4 & 21 & 19 & 75 & 14,1365 & 1,1385 & 1.7761 & 7,96 \\
\hline $12-14$ & 82,8 & 0.4 & 82,4 & 17,2 & 21 & 18 & 75 & 15,1036 & 1,1940 & 1,6658 & 9,07 \\
\hline $14-16$ & 82,6 & 0,6 & 82,0 & 17,4 & 21 & 19 & 73 & 15,4127 & 1,2799 & 1,4818 & 10,40 \\
\hline $16-18$ & 82,6 & 0.4 & 82,2 & 17.4 & 21 & 21 & 73 & 15,5203 & 1,3833 & 1,5200 & 10,21 \\
\hline $18-20$ & 81,8 & 0,2 & 81,6 & 18,2 & 21 & 22 & 72 & 14,9677 & 1,3912 & 1,5150 & $9,8 B$ \\
\hline $20-22$ & 82,8 & 0.4 & 82,4 & 17.2 & 20 & 20 & 78 & 14,9917 & 1,8582 & 1,5457 & 9,70 \\
\hline $22-24$ & 82,6 & 0,2 & 82,4 & 17,4 & 21 & 22 & 80 & 15,3375 & 2,0278 & 1,4491 & 10,58 \\
\hline $24-26$ & 83,0 & 0,2 & 82,8 & 17,0 & 21 & 21 & 79 & 15,6405 & 2,3397 & 1,4431 & 10,84 \\
\hline $26-28$ & 82,0 & 0,4 & 81,6 & 18,0 & 21 & 19 & 80 & 15,2111 & 2,2131 & 1,4358 & 10,59 \\
\hline $28-30$ & 82,8 & 0.4 & 82,4 & 17,2 & 20 & 23 & 76 & 13,9563 & 2,2316 & 1,2323 & $\$ 1,33$ \\
\hline $30-32$ & 82,2 & 0,4 & 81,8 & 17,8 & 20 & 22 & 77 & 13,9664 & 2,2608 & 1,3390 & 10,45 \\
\hline $32-34$ & 81,6 & 0,2 & 81,4 & 18.4 & 20 & 26 & 80 & 14,6023 & 2,3836 & 1,4272 & 10,23 \\
\hline $34-36$ & 81,8 & 0,2 & 81,6 & 18,2 & 20 & 20 & 79 & 13,3553 & 2,5069 & 1,3422 & 9,95 \\
\hline $36-38$ & 81,8 & 0,6 & 81,2 & 18,2 & 21 & 24 & 80 & 13,9814 & 2,7305 & 1,3543 & 10,32 \\
\hline $38-40$ & - & - & - & - & 20 & 16 & 77 & 11,4104 & 2,4737 & 1,3965 & 8,17 \\
\hline $40-42$ & 82,2 & 0,4 & 81,8 & 17.8 & 20 & 19 & 77 & 13,1224 & 2,6805 & 1,3848 & 9,48 \\
\hline $42-44$ & 82,4 & 0,2 & 82,2 & 17,6 & 20 & 21 & 74 & 13,3067 & 2,9349 & 1,3485 & 9,87 \\
\hline $44-46$ & 82,8 & 0,4 & 82,4 & 17,2 & 18 & 17 & 76 & 13,2349 & 2,8479 & 1,2629 & 10,48 \\
\hline $46-48$ & 82,4 & 0,2 & 82,2 & 17,6 & 18 & 18 & 78 & 12,8252 & 2,8810 & 1,2706 & 10,09 \\
\hline \multicolumn{12}{|c|}{ Testemunho 6696} \\
\hline $0-2$ & 78,0 & 5,0 & 73.0 & 22,0 & 20 & 21 & 81 & 14,0899 & 0,5263 & 1,3906 & 10,13 \\
\hline $2-4$ & 76,6 & 4,2 & 72,4 & 23,4 & 21 & 27 & 84 & 13,5349 & 0,6135 & 9.4048 & 9,63 \\
\hline $4-6$ & 78,0 & 4,8 & 73,2 & 22,0 & 20 & 29 & 81 & 13,6207 & 0,7106 & 1,3385 & 10,18 \\
\hline $6-8$ & 77,8 & 4,4 & 73,4 & 22,2 & 20 & 20 & 83 & 13,3218 & 0,9165 & 1,3072 & 10,19 \\
\hline $8-10$ & 76,8 & 4,2 & 72,6 & 23.2 & 21 & 24 & 85 & 13,1679 & 1,0002 & 1,3281 & 9,91 \\
\hline $10-12$ & - & - & - & - & 20 & 22 & 82 & 13,6955 & 1,1432 & 1,3037 & 10,51 \\
\hline $12-14$ & 77,6 & 5,4 & 72,2 & 22,4 & 20 & 19 & 82 & 14,0231 & 1,3073 & 1,6147 & 8,68 \\
\hline $14-16$ & 77,2 & 4,0 & 73,2 & 22,8 & 20 & 22 & 81 & 13,6235 & 1,4105 & 1,5716 & 8,67 \\
\hline $16-18$ & 78,2 & 4,8 & 73.4 & 21,8 & 18 & 25 & 73 & 13,0554 & 1,8122 & 1,4318 & 9,12 \\
\hline $18-20$ & 77,8 & 4.2 & 73,6 & 22,2 & 18 & 21 & 76 & 12,9748 & 2,2303 & 1,4320 & 9,07 \\
\hline $20-22$ & 77,0 & 3.8 & 73,2 & 23,0 & 18 & 19 & 63 & 14,4058 & 2,5984 & 1,4322 & 10,06 \\
\hline $22-24$ & 78,6 & 4,4 & 74.2 & 21,4 & 20 & 17 & 76 & 13,1474 & 2,6997 & 1,4647 & 8,98 \\
\hline $24-26$ & 78.4 & 4,8 & 73,6 & 21,6 & 21 & 22 & 83 & 12,8714 & 2,9514 & 1,4894 & 8,64 \\
\hline $26-28$ & 78.6 & 4,2 & 74,4 & 21,4 & 20 & 22 & 85 & 13,2487 & 2,7864 & 1,4821 & 8,94 \\
\hline $28-30$ & 78,4 & 5,2 & 73,2 & 21,6 & 21 & 31 & 86 & 13,5098 & 3,0082 & 1.4439 & 9,36 \\
\hline $30-32$ & 78,0 & 4,4 & 73,6 & 22,0 & 20 & 21 & 83 & 13,3208 & 2,8299 & 1,3955 & 9,55 \\
\hline $32-34$ & 77,4 & 3,0 & 74,4 & 22,6 & 19 & 21 & 81 & 11,7361 & 2,8243 & 1,3377 & 8,77 \\
\hline $34-36$ & 77.8 & 4,2 & 73.6 & 22,2 & 20 & 22 & 93 & 12,5778 & 2,9917 & 1,3477 & 9,33 \\
\hline $36-38$ & 78,4 & 4,2 & 74,2 & 21,6 & 19 & 18 & 81 & 11,2255 & 3,5262 & 1,2796 & 8,77 \\
\hline $38-40$ & 78.2 & 4,8 & 73,4 & 21,8 & 20 & 22 & 84 & 12,0827 & 3,4138 & 1,3540 & 8,92 \\
\hline $40-42$ & 77.8 & 4,4 & 73,4 & 22,2 & 19 & 19 & 83 & 11,8614 & 2,9959 & 1,3506 & 8,78 \\
\hline $42-44$ & 77.4 & 4,6 & 72,8 & 22,6 & 17 & 17 & 59 & 11,6003 & 3,4380 & 1,2696 & 9,14 \\
\hline $44-46$ & 77.6 & 4,6 & 73,0 & 22,4 & 17 & 19 & 59 & 11.7965 & 3,0574 & 1,3092 & 9,01 \\
\hline \multicolumn{12}{|c|}{ Testemunho 6700} \\
\hline $0-2$ & 80.4 & 0,6 & 79,8 & 19,6 & 19 & 20 & 65 & 15,4247 & 0,3746 & 1,6806 & 9,18 \\
\hline $2-4$ & 80,2 & 0,4 & 79,8 & 19,8 & 20 & 24 & 79 & 15,5326 & 0,3414 & 1,6642 & 9,33 \\
\hline $4-6$ & 79,8 & 0,8 & 79,0 & 20,2 & 20 & 27 & 75 & 13,3254 & 0.3284 & 1,6768 & 7,95 \\
\hline $6-8$ & 80,2 & 0,6 & 79,6 & 19,8 & 21 & 22 & 75 & 12,9969 & 0.4475 & 1,5640 & 8,31 \\
\hline $8-10$ & 79,6 & 1,0 & 78,6 & 20,4 & 22 & 20 & 74 & 12,1852 & 0.4298 & 1,4951 & 8,15 \\
\hline $10-12$ & 79.8 & 0,6 & 79,2 & 20,2 & 20 & 24 & 75 & 12,8792 & 0,5495 & 1,4913 & 8,64 \\
\hline $12-14$ & 79,4 & 0,6 & 78,8 & 20,6 & 20 & 26 & 75 & 13,7597 & 0.7682 & 1,4912 & 9.23 \\
\hline $14-16$ & 80,0 & 0,4 & 79,6 & 20,0 & 20 & 20 & 76 & 12,3702 & 0,8679 & 1,4403 & 8.59 \\
\hline $16-18$ & 79,0 & 0,4 & 78,6 & 21,0 & 21 & 24 & 79 & 13,0975 & 1,1541 & 1,4421 & 9.08 \\
\hline $18-20$ & 79,6 & 1,2 & 78,4 & 20,4 & 18 & 27 & 59 & 13,6137 & 1,4640 & 1,4411 & 9.45 \\
\hline $20-22$ & 79,2 & 0,6 & 78,6 & 20,8 & 18 & 22 & 60 & 13,1880 & 1,4973 & 1,4489 & 9,10 \\
\hline $22-24$ & 81,2 & 0,8 & 80.4 & 18,8 & 10 & 19 & 59 & 13,4030 & 1.5590 & 1,4706 & 9,11 \\
\hline $24-26$ & 80,6 & 0,6 & 80,0 & 19,4 & 18 & 19 & 62 & 13,6737 & 1.7930 & 1,4884 & 9,19 \\
\hline $26-28$ & 80,6 & 0,6 & 80,0 & 19.4 & 19 & 26 & 66 & 12,8869 & 2,0282 & 1,4293 & 9,00 \\
\hline $28-30$ & 81,2 & 0,8 & 80,4 & 18,8 & 19 & 22 & 65 & 13,0026 & 2,3424 & 1,4421 & 9,02 \\
\hline $30-32$ & 81,0 & 1,0 & 80,0 & 19,0 & 19 & 27 & 66 & 13,2180 & 2,4177 & 1,4048 & 9,41 \\
\hline $32-34$ & 80,0 & 0,6 & 79.4 & 20,0 & 19 & 30 & 65 & 13,3549 & 2,4106 & 1,4109 & 9,47 \\
\hline $34-36$ & 80,4 & 0,8 & 79,6 & 19,6 & 19 & 17 & 66 & 13,2552 & 2,5234 & 1,4022 & 9,45 \\
\hline
\end{tabular}




\begin{tabular}{|c|c|c|c|c|c|c|c|c|c|c|c|}
\hline $0-2$ & - & - & - & - & 21 & 41 & 74 & 16,2754 & 0,3712 & 1,8588 & 8,76 \\
\hline $2-4$ & - & - & - & - & 22 & 39 & 81 & 15,8507 & 0,4925 & 1,8215 & 8,70 \\
\hline 4.6 & - & - & - & - & 18 & 23 & 60 & 15,4304 & 0,4359 & 1.7246 & 8,95 \\
\hline 6.8 & 80,4 & 0,2 & 19,6 & 19,6 & 19 & 19 & 61 & 16,9044 & 0,5416 & 1,8914 & 0.94 \\
\hline 0.10 & 80,4 & 0,4 & 19,6 & 19,6 & 19 & 22 & 64 & 17,9513 & 0,4811 & 1,8895 & 9,50 \\
\hline $10-12$ & 81,6 & 0,4 & 18,4 & 18,4 & 20 & 26 & 65 & 16,4766 & $0,457 \theta$ & 1,7515 & 9.41 \\
\hline $12-14$ & 80,8 & 0,6 & 19.2 & 19,2 & 19 & 21 & 70 & 16,0675 & 0.4397 & 1,7359 & 9,26 \\
\hline $14-16$ & 80,4 & 1,2 & 19,6 & 19.6 & 20 & 21 & 69 & 16,0803 & 0,6322 & 1,6883 & 9,52 \\
\hline $16-18$ & 81,2 & 0,6 & $\uparrow 8,8$ & 18,8 & 20 & 26 & 69 & 16,3609 & 0,5559 & 1,6886 & 9,81 \\
\hline $18-20$ & 80,2 & 0,8 & 19,0 & 19.8 & 20 & 24 & 67 & 15,9000 & 0.7416 & 1,6161 & 9,84 \\
\hline $20-22$ & 80,8 & 0,6 & 19,2 & 19.2 & 19 & 20 & 65 & 17,6811 & 1.0519 & 1,6706 & 10,58 \\
\hline $22-24$ & 79,8 & 1,0 & 20,2 & 20,2 & 22 & 21 & 75 & 15,1082 & 1,3994 & 1,6544 & 9,13 \\
\hline $24-26$ & 81,4 & 0,4 & 18,6 & 18,6 & 22 & 23 & 78 & 15,8282 & 1,5235 & 0,7090 & 9.26 \\
\hline $26-28$ & 81,0 & 0,4 & 19,0 & 19,0 & 18 & 18 & 60 & 15,4345 & 1,4155 & 1,6864 & 9,16 \\
\hline $28-30$ & 81,0 & 1,4 & 19,0 & 19,0 & 19 & 20 & 61 & 14,6974 & 1,5062 & 1.6073 & 9,14 \\
\hline $30-32$ & 79,6 & 0,6 & 20.4 & 20,4 & 18 & 20 & 64 & 15,6013 & 1,5753 & 1,7090 & 9,13 \\
\hline $32-34$ & 80,2 & 1,0 & 19,8 & 19,8 & 19 & 16 & 68 & 14,7503 & 1,7159 & 1.5694 & 9,40 \\
\hline $34-36$ & 80,6 & 1,2 & 19,4 & 19,4 & 18 & 19 & 70 & 14,6505 & 1,6492 & 1,5242 & 9.61 \\
\hline $36-38$ & 80,4 & 0,6 & 19.6 & 19,6 & 20 & 19 & 75 & 14,6054 & 1,7039 & 1,5229 & 9,59 \\
\hline $38-40$ & 81,2 & 0,4 & 18,8 & 18,8 & 19 & 18 & 74 & 14,6056 & 1,9220 & 1,5677 & 9,32 \\
\hline $40-42$ & 80.4 & 0,4 & 19,6 & 19,6 & 19 & 21 & 74 & $\{4,0237$ & 2,4445 & 1,5122 & 9,27 \\
\hline $42-44$ & 81,0 & 0,6 & 19,0 & 19,0 & 18 & 20 & 71 & 13,6896 & 2,6617 & 1,4955 & 9,15 \\
\hline $44-46$ & 80,6 & 1,4 & 19,4 & 19.4 & 19 & 20 & 75 & 13,9505 & 2,8421 & 1.5028 & 9,28 \\
\hline $46-48$ & 81.4 & 0,8 & 18,6 & 18,6 & 19 & 19 & 78 & 14,6647 & 3,0451 & 1.6541 & 8,87 \\
\hline
\end{tabular}




\section{Lixiviado 1}

$\begin{array}{rrrrrrrr} & \text { erro } & 207 / 204 & \text { erro } & 208 / 204 & \text { erro } & \text { Testemunho } & \text { Profundidade } \\ 1 & 0.014 & 15.729 & 0.012 & 38.890 & 0.014 & 6652 & 10-12 \mathrm{~cm} \\ 2 & 0.013 & 15.665 & 0.017 & 38.858 & 0.017 & 6653 & 10-12 \mathrm{~cm} \\ 3 & 0.012 & 15.735 & 0.010 & 38.799 & 0.017 & 6653 & 20-22 \mathrm{~cm} \\ 4 & 0.015 & 15.689 & 0.016 & 38.880 & 0.017 & 6654 & 10-12 \mathrm{~cm} \\ 5 & 0.014 & 15.614 & 0.015 & 38.695 & 0.014 & 6654 & 28-30 \mathrm{~cm} \\ 6 & 0.010 & 15.690 & 0.010 & 38.899 & 0.009 & 6655 & 10-12 \mathrm{~cm} \\ 7 & 0.012 & 15.667 & 0.012 & 38.809 & 0.012 & 6655 & 28-30 \mathrm{~cm} \\ 8 & 0.153 & 15.713 & 0.156 & 38.935 & 0.163 & 6657 & 10-12 \mathrm{~cm} \\ 9 & 0.020 & 15.677 & 0.019 & 38.835 & 0.019 & 6657 & 20-22 \mathrm{~cm} \\ 10 & & & & -.-- & --- & 6658 & 02-04 \mathrm{~cm} \\ 11 & 0.104 & 15.599 & 0.101 & 38.633 & 0.106 & 6658 & 06-10 \mathrm{~cm} \\ 12 & 0.018 & 15.692 & 0.015 & 39.047 & 0.017 & 6692 & 10-12 \mathrm{~cm} \\ 13 & 0.013 & 15.698 & 0.011 & 38.724 & 0.012 & 6696 & 10-12 \mathrm{~cm} \\ 14 & 0.031 & 15.714 & 0.019 & 38.775 & 0.022 & 6700 & 10-12 \mathrm{~cm} \\ 15 & 0.011 & 15.768 & 0.012 & 38.946 & 0.012 & 6704 & 10-12 \mathrm{~cm}\end{array}$

\section{Lixiviado 2}

$\begin{array}{rrrrrrrr} & \text { erro } & 207 / 204 & \text { erro } & 208 / 204 & \text { erro } & \text { Testemunho } & \text { Profundidade } \\ 1 & 0.008 & 15.779 & 0.009 & 39.067 & 0.009 & 6652 & 10-12 \mathrm{~cm} \\ 2 & 0.009 & 15.658 & 0.008 & 40.041 & 0.007 & 6653 & 10-12 \mathrm{~cm} \\ 3 & 0.010 & 15.683 & 0.009 & 38.936 & 0.011 & 6653 & 20-22 \mathrm{~cm} \\ 4 & 0.010 & 15.643 & 0.010 & 38.869 & 0.010 & 6654 & 10-12 \mathrm{~cm} \\ 5 & 0.016 & 15.646 & 0.017 & 38.503 & 0.018 & 6654 & 28-30 \mathrm{~cm} \\ 6 & 0.010 & 15.638 & 0.011 & 38.857 & 0.012 & 6655 & 10-12 \mathrm{~cm} \\ 7 & 0.012 & 15.660 & 0.012 & 38.874 & 0.012 & 6655 & 28-30 \mathrm{~cm} \\ 8 & 0.323 & 15.656 & 0.337 & 38.950 & 0.352 & 6657 & 10-12 \mathrm{~cm} \\ 9 & 0.018 & 15.639 & 0.012 & 38.948 & 0.012 & 6657 & 20-22 \mathrm{~cm} \\ 10 & --- & -- & -- & -- & - & 6658 & 02-04 \mathrm{~cm} \\ 11 & 0.096 & 15.591 & 0.091 & 38.661 & 0.095 & 6658 & 06-10 \mathrm{~cm} \\ 12 & 0.014 & 15.633 & 0.012 & 38.790 & 0.012 & 6692 & 10-12 \mathrm{~cm} \\ 13 & 0.025 & 15.525 & 0.021 & 37.746 & 0.025 & 6696 & 10-12 \mathrm{~cm} \\ 14 & 0.014 & 15.685 & 0.015 & 37.928 & 0.013 & 6700 & 10-12 \mathrm{~cm} \\ 15 & 0.010 & 15.750 & 0.008 & 39.089 & 0.012 & 6704 & 10-12 \mathrm{~cm}\end{array}$




$\begin{array}{cccc}\text { Testemunho } & \text { Profundidade }(\mathrm{cm}) & n^{\circ} \text { Beta } & \begin{array}{c}\text { Idade calibrada (B.P.) } \\ \text { (corrigida para 2000) }\end{array} \\ 6651 & 02-04 & 142532 & 1585 \text { anos B.P. } \\ 6651 & 28-30 & 142533 & 3530 \\ 6652 & 10-12 & 142534 & 2695 \\ 6653 & 10-12 & 142535 & 1990 \\ 6654 & 34-36 & 142536 & 2375 \\ 6692 & 02-04 & 142539 & 1315 \\ 6692 & 44-46 & 142540 & 1610 \\ 6696 & 02-04 & 142541 & 1400 \\ 6696 & 42-44 & 142542 & 1775 \\ 6700 & 02-04 & 142543 & 1160 \\ 6700 & 32-34 & 142544 & 1580 \\ 6704 & 02-04 & 142545 & 1235 \\ 6704 & 28-30 & 142546 & 1615 \\ 6683 & 02-04 & 142537 & 1100 \\ 6683 & 40-42 & 142538 & 2115\end{array}$

Tabela 4 . Resultados obtidos para as taxas de sedimentação. Idades calibradas ${ }^{14} \mathrm{C}$. Beta Analytics 


\begin{tabular}{c|c}
\hline Testemunho (Core) & Taxa de sedimentação (cm.ano ${ }^{-1}$ ) \\
6651 & $0,101 \pm 0,040$ \\
6653 & $0,145 \pm 0,051$ \\
6654 & $0,217 \pm 0,010$ \\
6655 & $0,305 \pm 0,046$ \\
6658 & $0,224 \pm 0,016$ \\
$6683(0-22 \mathrm{~cm})$ & $0,666 \pm 0,009$ \\
$6683(0-28 \mathrm{~cm})$ & $0,196 \pm 0,011$ \\
6692 & $0,262 \pm 0,036$ \\
6696 & $0,198 \pm 0,013$ \\
6700 & $0,174 \pm 0,043$ \\
6704 & $0,202 \pm 0,007$ \\
Valor Médio* & $\mathbf{0 , 2 0 2} \pm \mathbf{0 , 0 5 7}$ \\
\hline
\end{tabular}

${ }^{*}$ excetuando-se o testemunho $6683(0-22 \mathrm{~cm})$

Tabela 5. Resultados obtidos para a taxa de sedimentação nos diferentes testemunhos. 


\section{FIGURAS}




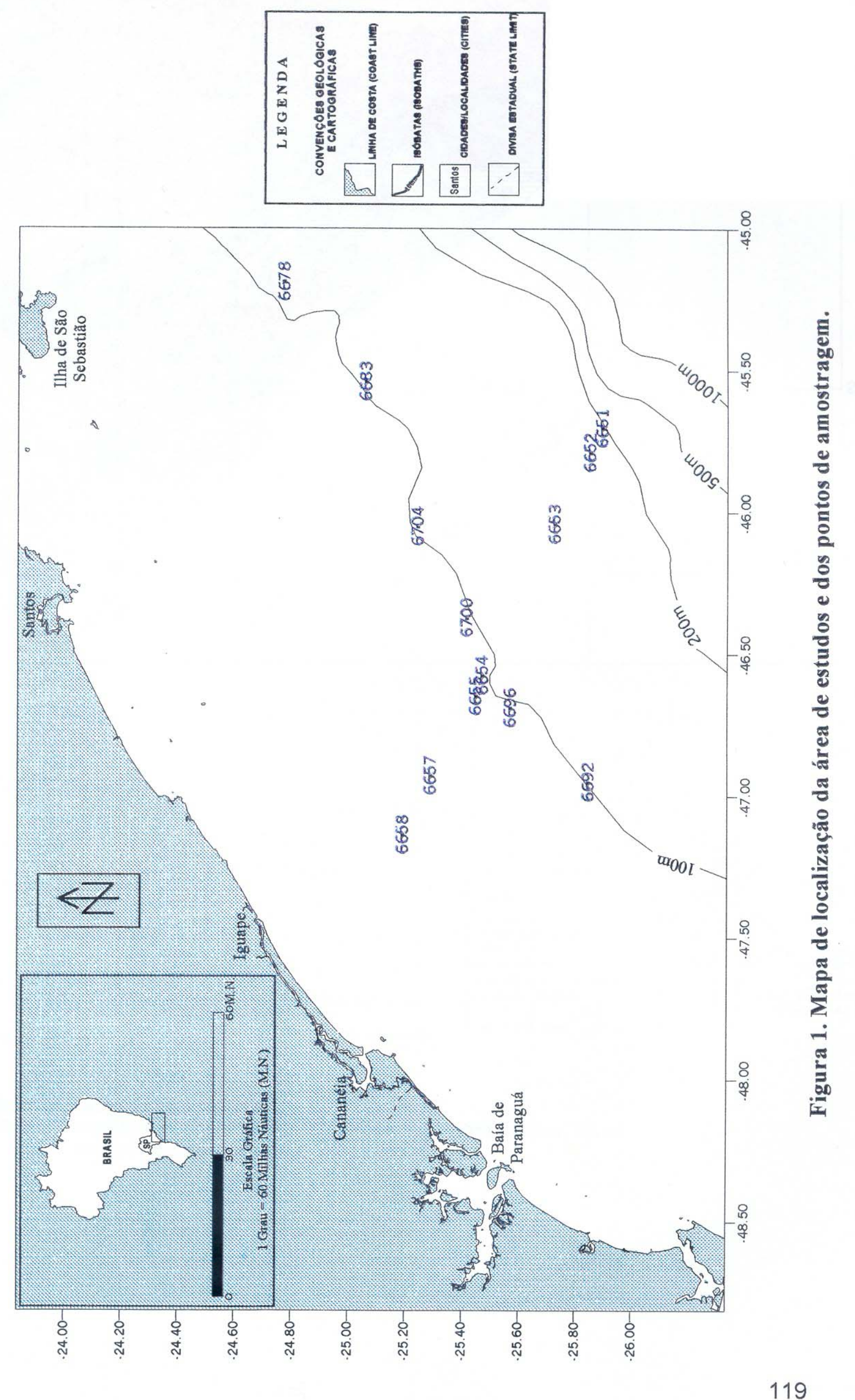




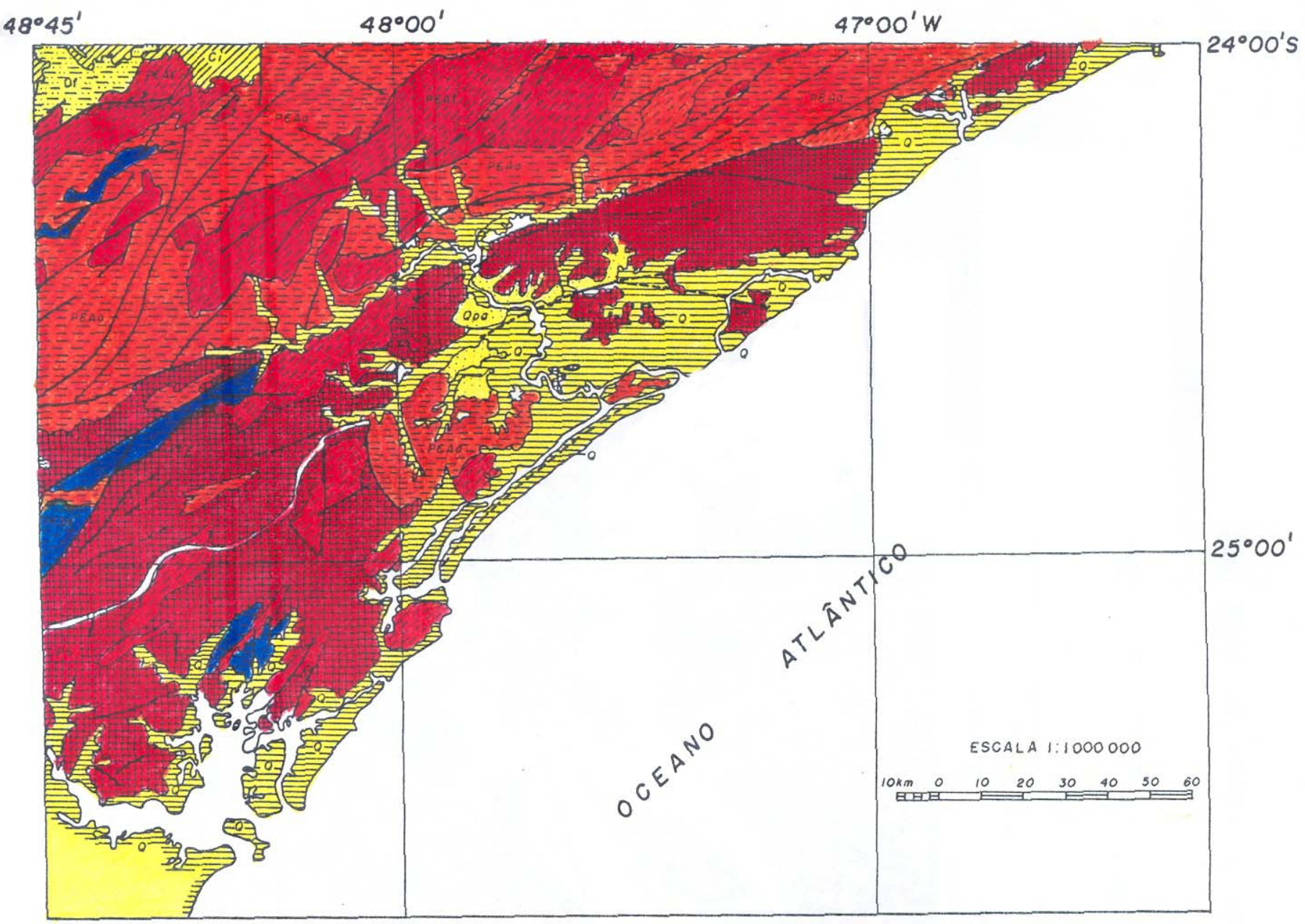

- Contocto lifoldgico

A Arelos, coscalnos, monguezois, depósitos coluviois.

QUATERNÁRIO

ARTICULACÃO DAS FOLHAS

LOCALIZACÃO DAS FOLHAS

[Dpo] Formogäo Pariquero-Agu: coscolhos, oreios, argilos

OUATERNÁRIO

CARBONIFERO

Eii] formosổo

Df: Formocöo Furnos: arenitos síttico-argilosos, con-

DEVONIANO

FEAT Gronitos o quortzodioritos nöo discriminados

EDEA0] Grupo Aqunqui: gnoisses, migmotisos, xistos, cochea

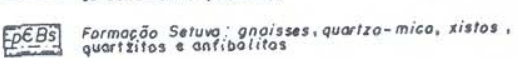

等笝 Complexo cristolino

$P R E ́-\varepsilon$ A OU SUP. NOVO

PRÉ-G A OU SUP NOVO

$P R E ́-\varepsilon$ B OU SUP. ANTIGO

PRÉ- $€$ NÃO DIFERENCIADO

\begin{tabular}{|c|c|c|}
\hline \multicolumn{1}{|c|}{1978} \\
$\begin{array}{r}\text { SE-22 } \\
\text { GOIANIA }\end{array}$ & $\begin{array}{c}\text { SE-23 } \\
\text { B.HORIZONTE }\end{array}$ & $\begin{array}{c}\text { SE-24 } \\
\text { RIO OOCE }\end{array}$ \\
\hline $\begin{array}{c}\text { SF-22 } \\
\text { PARANA. } \\
\text { PANEMA }\end{array}$ & R. DE JANEIRO & $\begin{array}{c}\text { SF-24 } \\
\text { VITORIA }\end{array}$ \\
\hline SG-22 & SG & \\
\hline CURITIBA & IGUAPE & \\
\hline
\end{tabular}

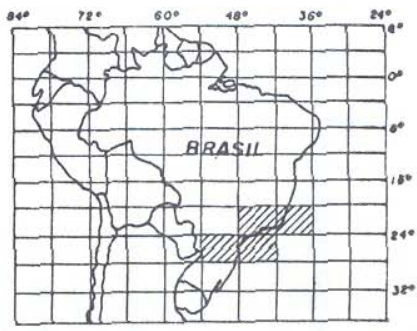

2. Mapa geológico do Vale do Ribeira.

Fonte: compilada da Carta Geológica ao Milionésimo, folhas Curitiba, Rio de Janeiro, Vitória e Iguape. 


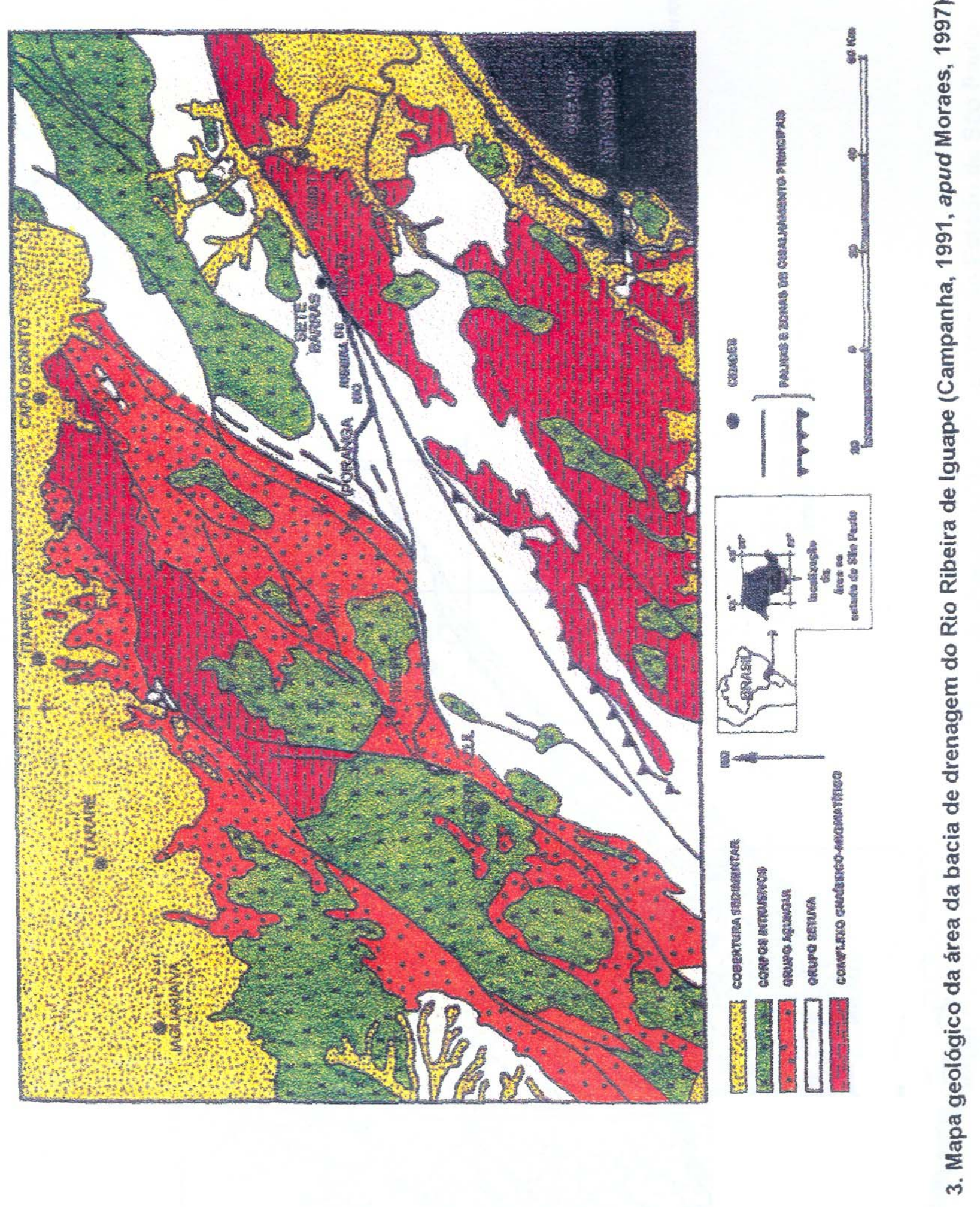




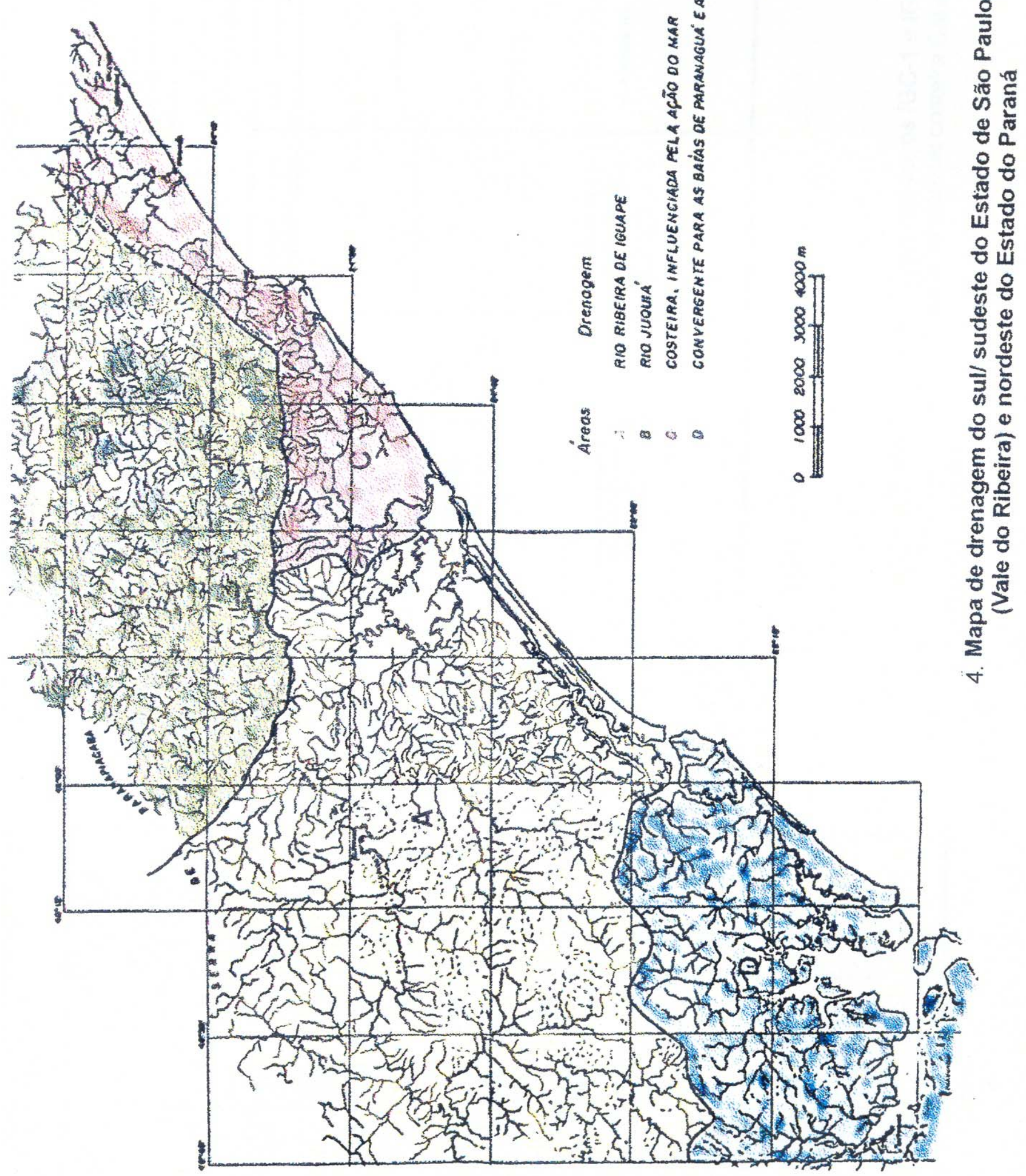



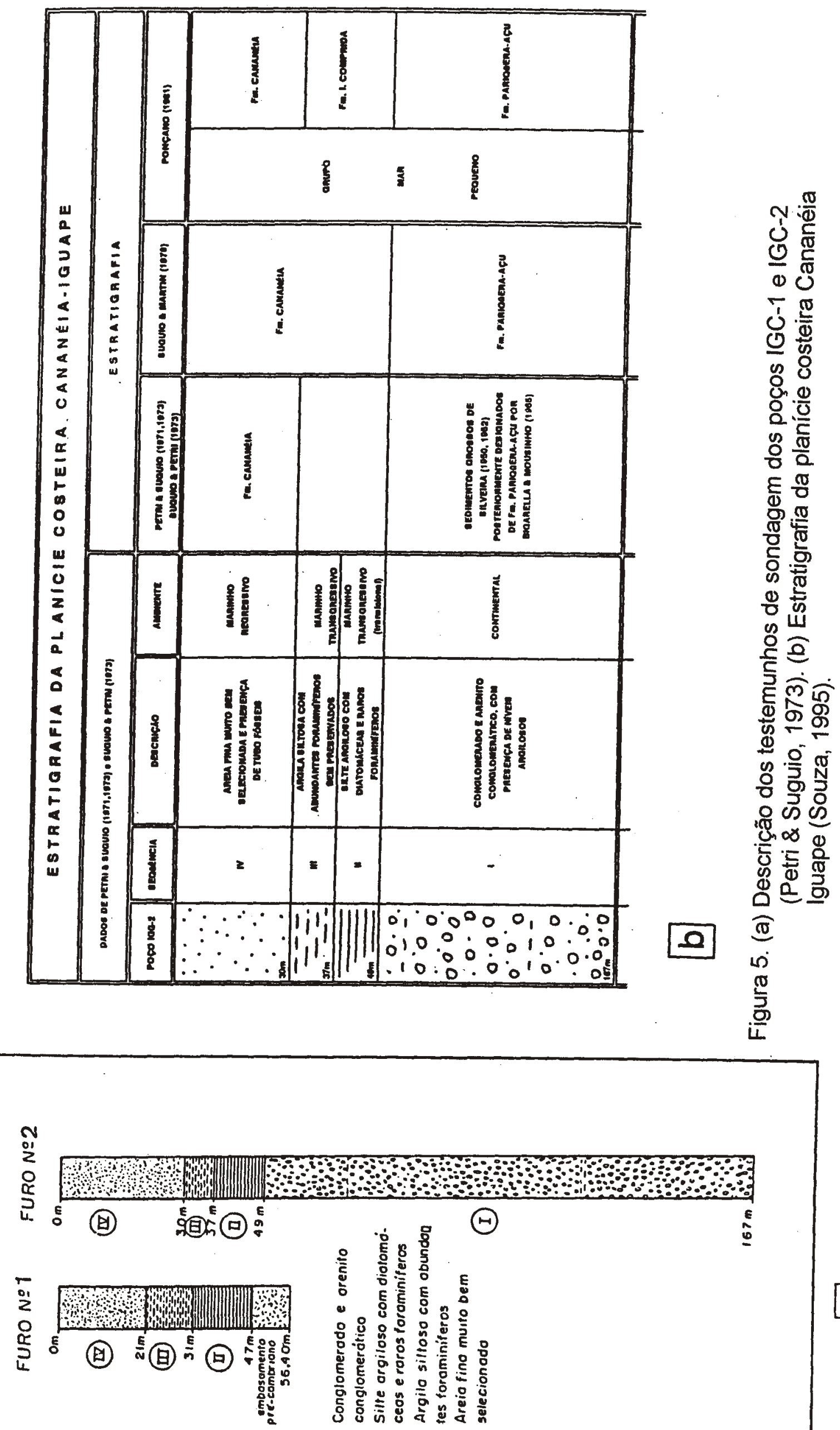

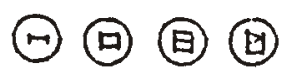




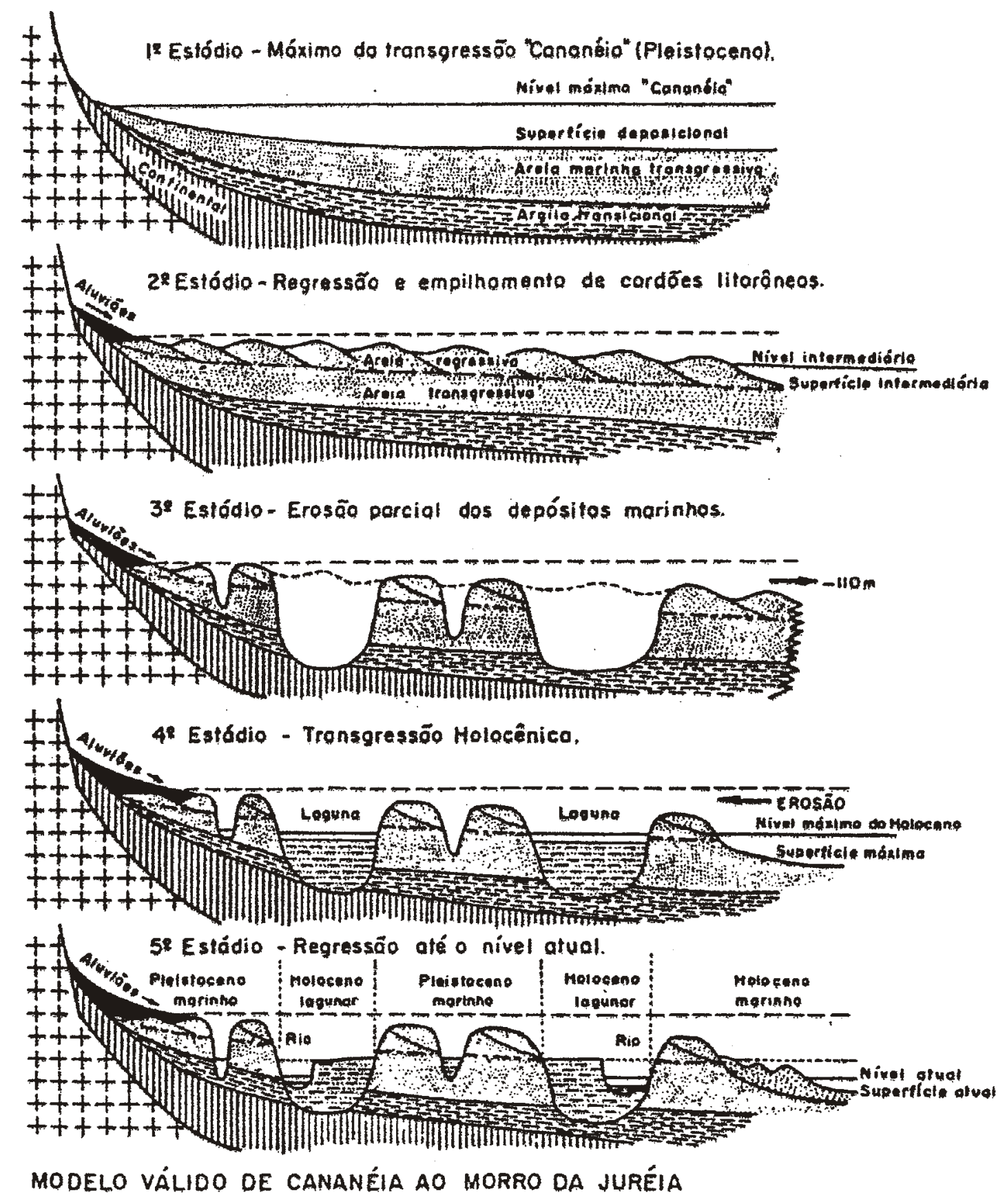

6. Estágios de formaçåo da planície costeira Cananéia - Iguape (Suguio \& Martin, 1978) 

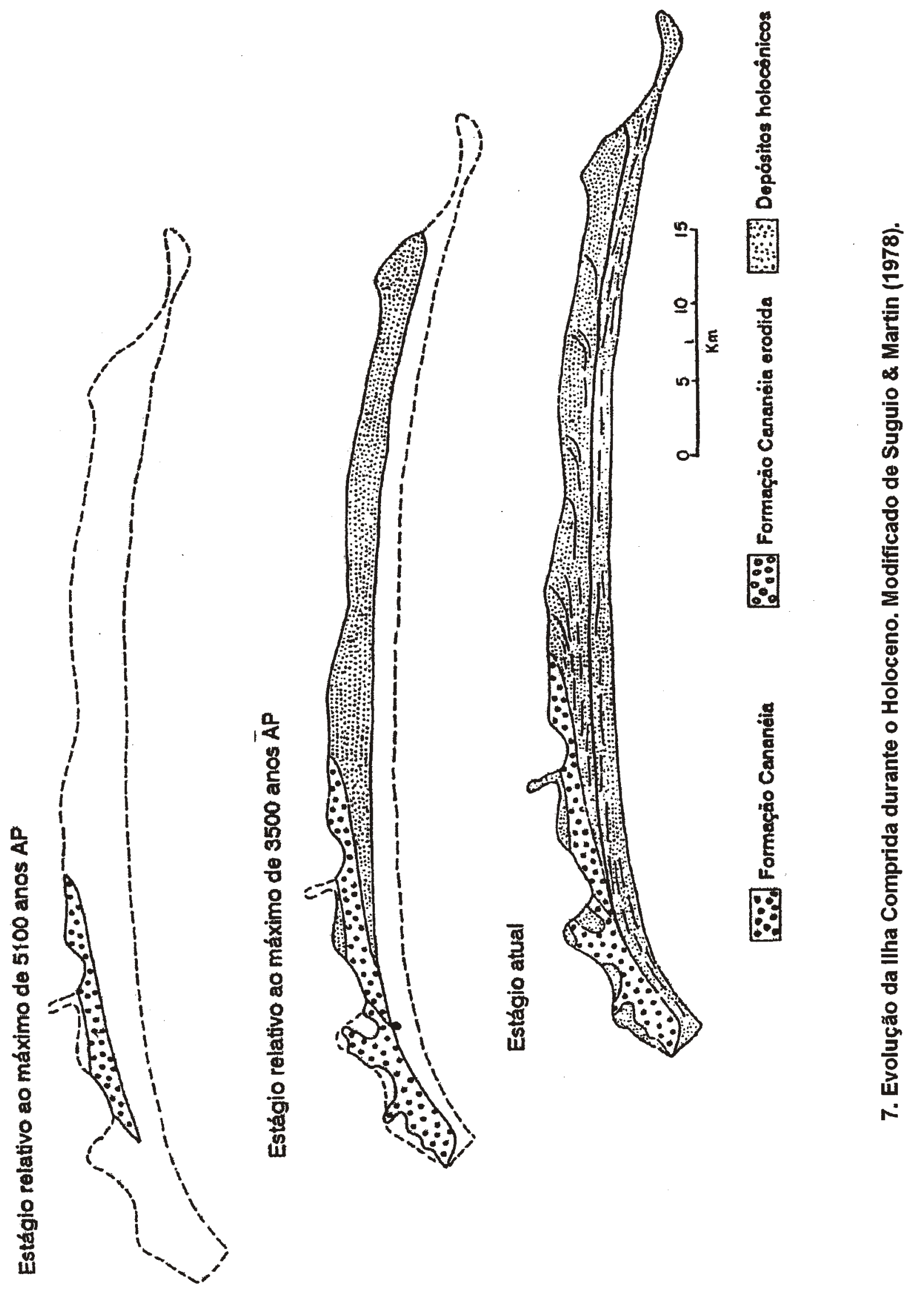


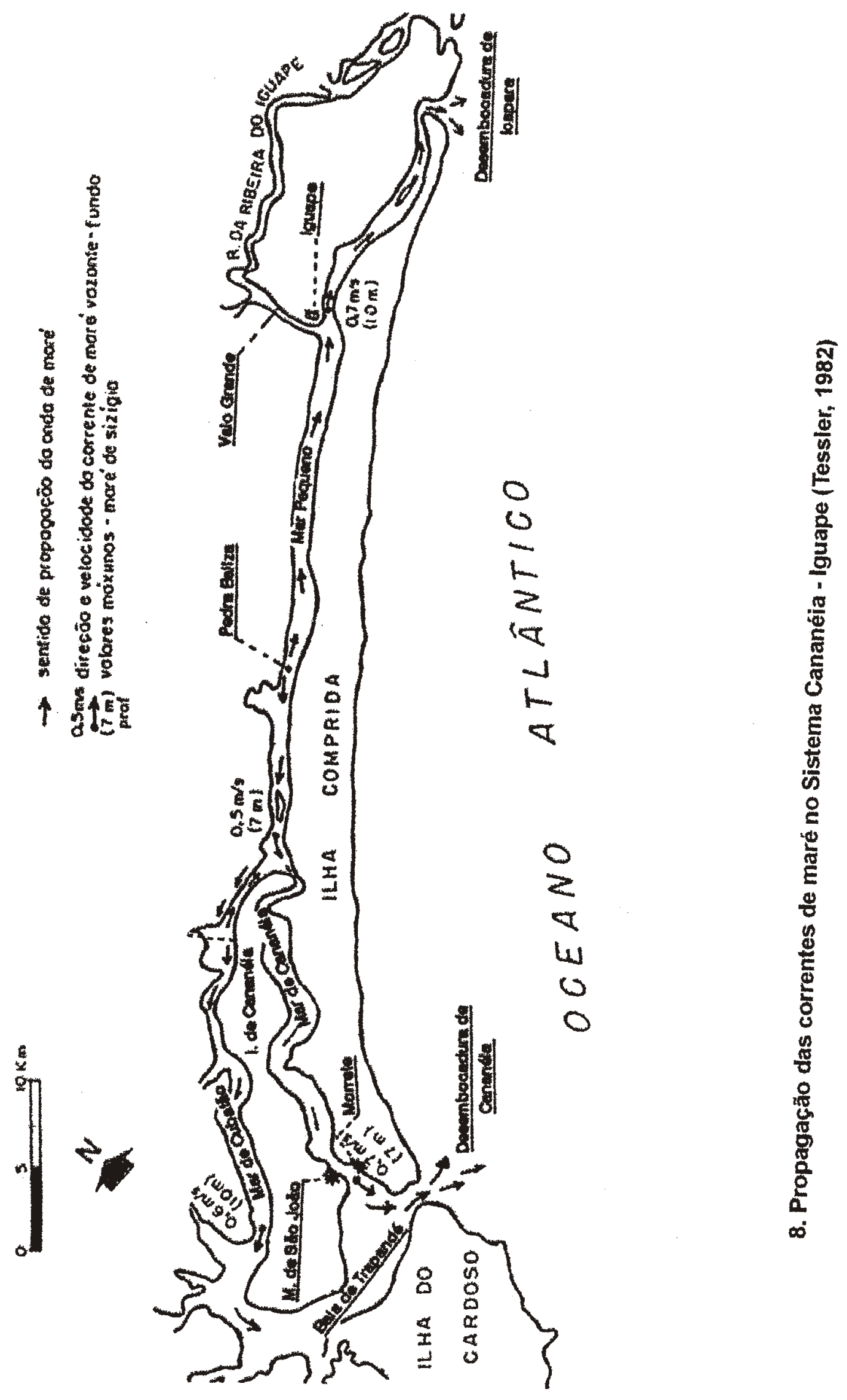



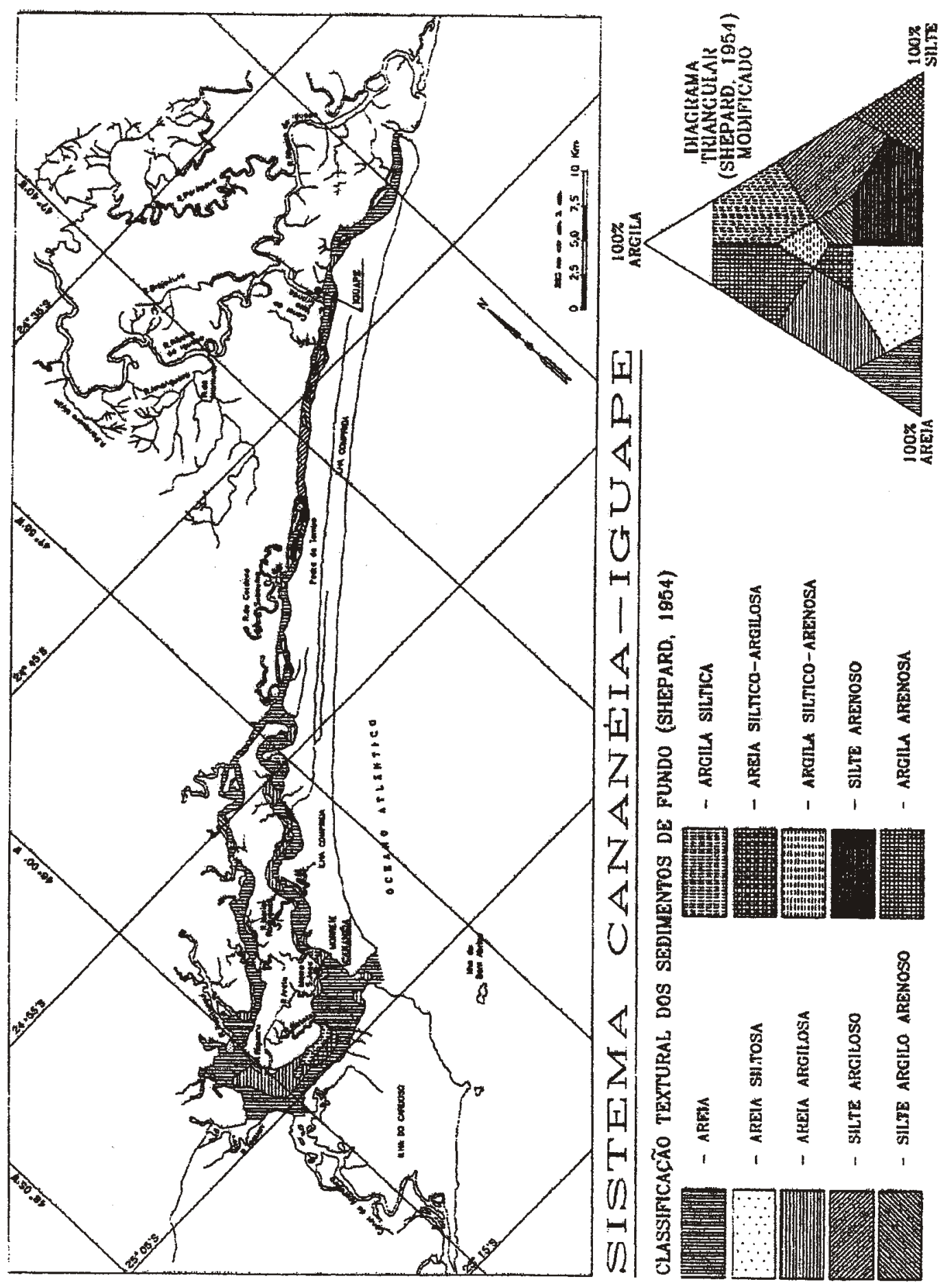

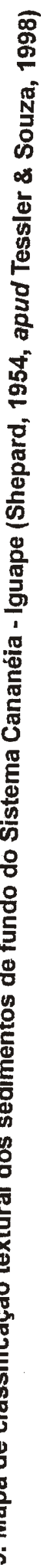




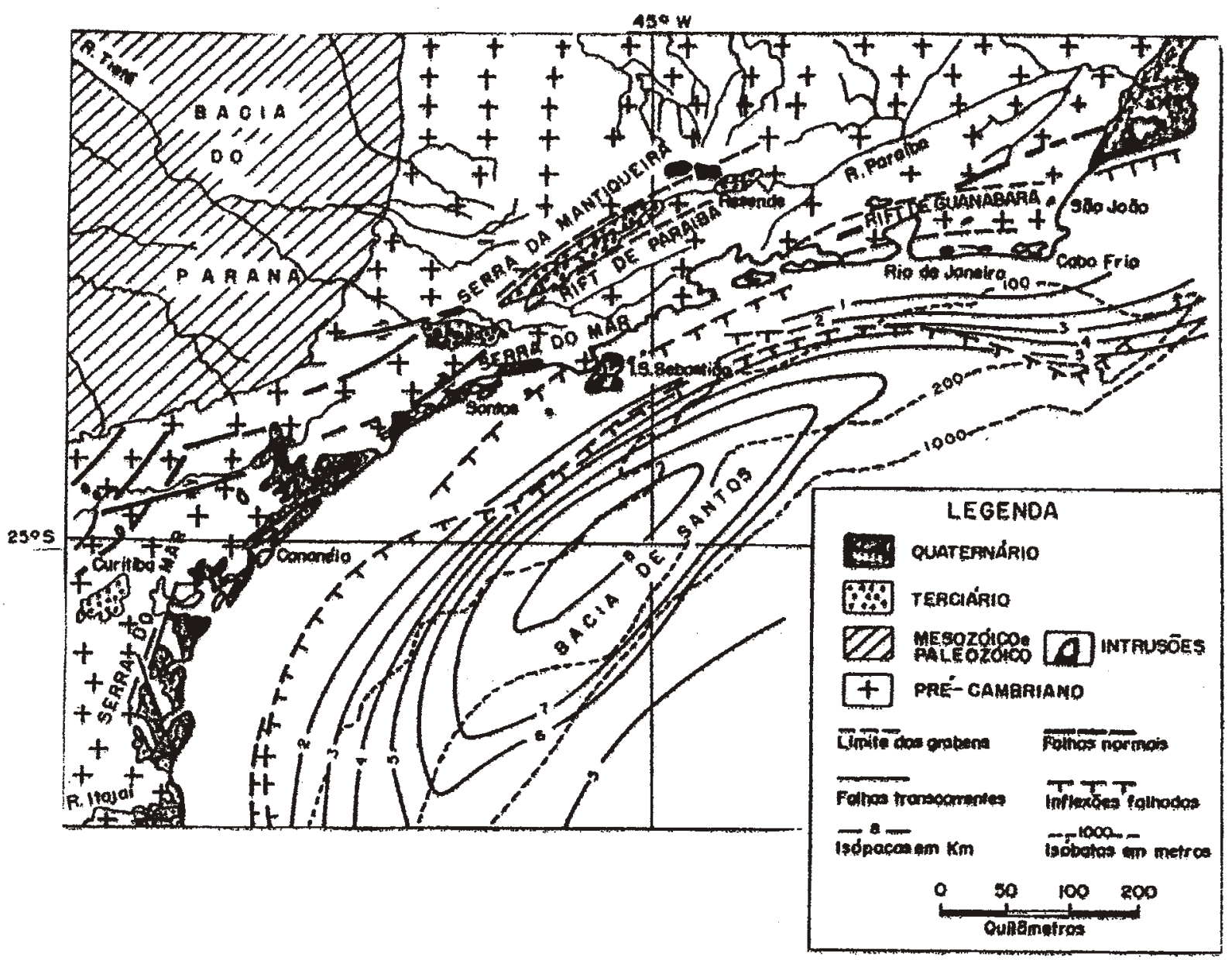

10. Esboço estrutural do sudeste brasileiro (Almelda, 1976, apud Suguio \& Martin, 1978) 

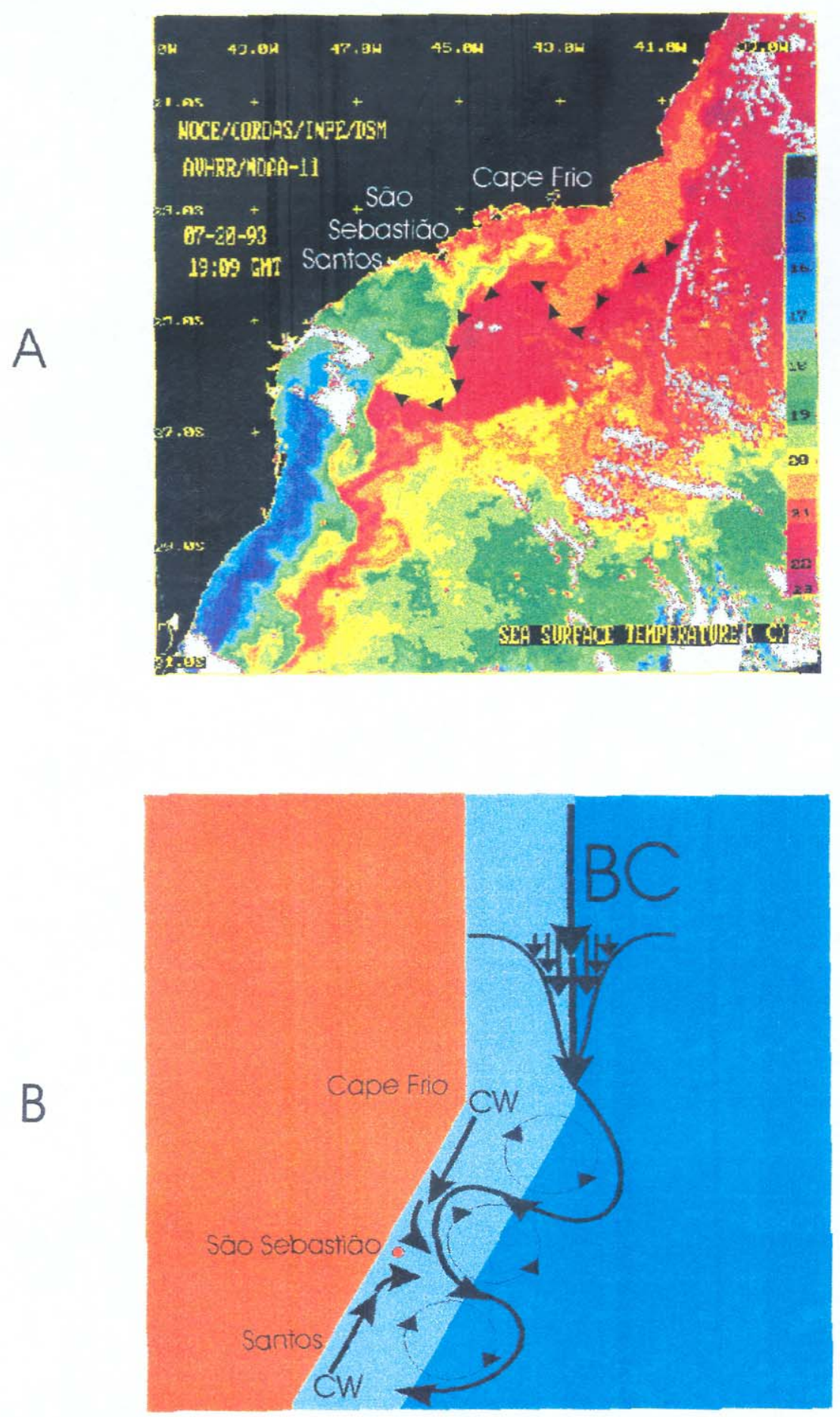

Figura 11. (A) Imagem AVHRR da margem continental brasileira, mostrando as assinaturas das temperaturas associadas com a Corrente do Brasil. (B) Representação esquemática do meandramento da Corrente do Brasil. (Mahiques et al., no prelo) 


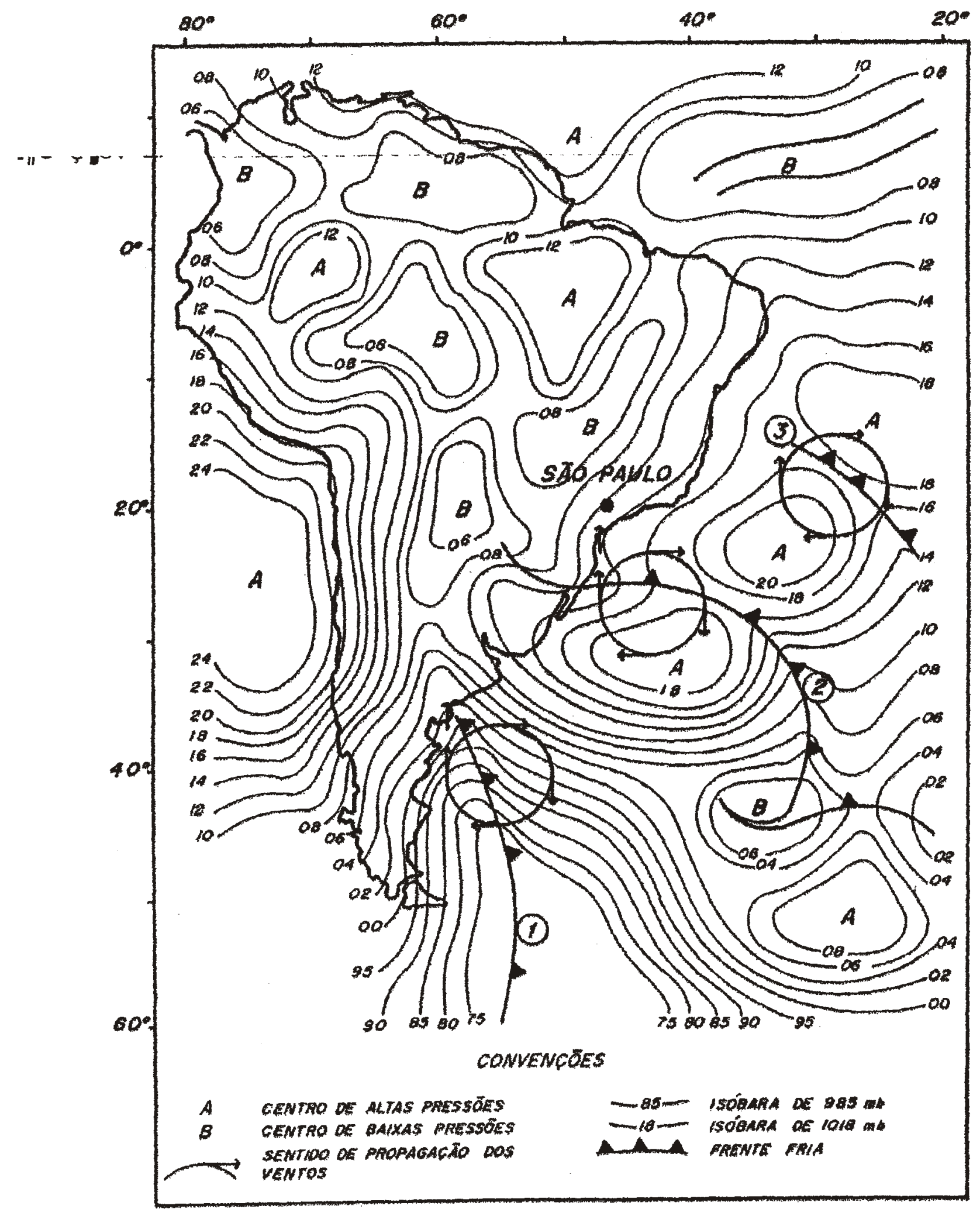

12. Esquema de propagação dos Sistemas Frontais no Atlântico Meridional (Rodrigues, 1996) 


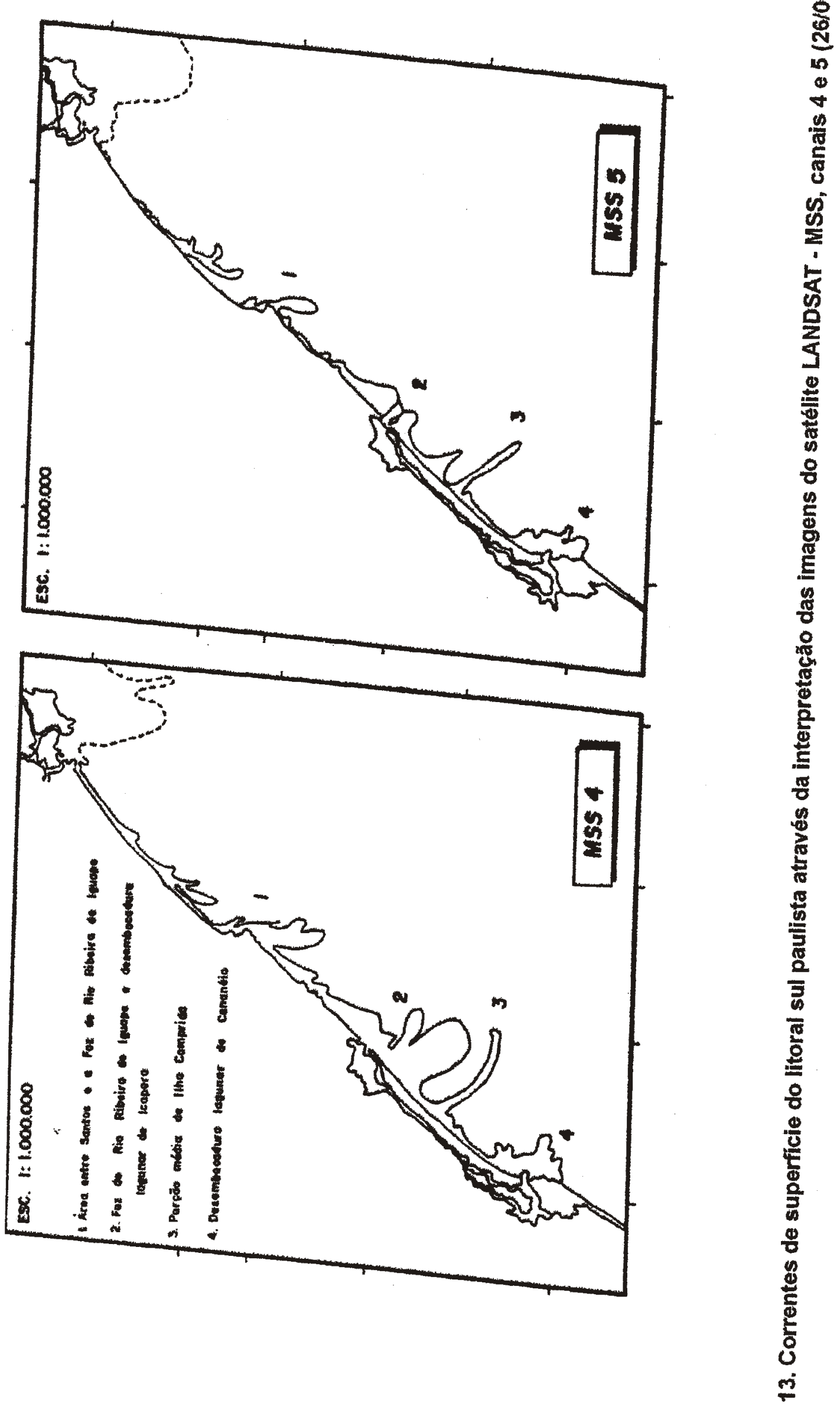




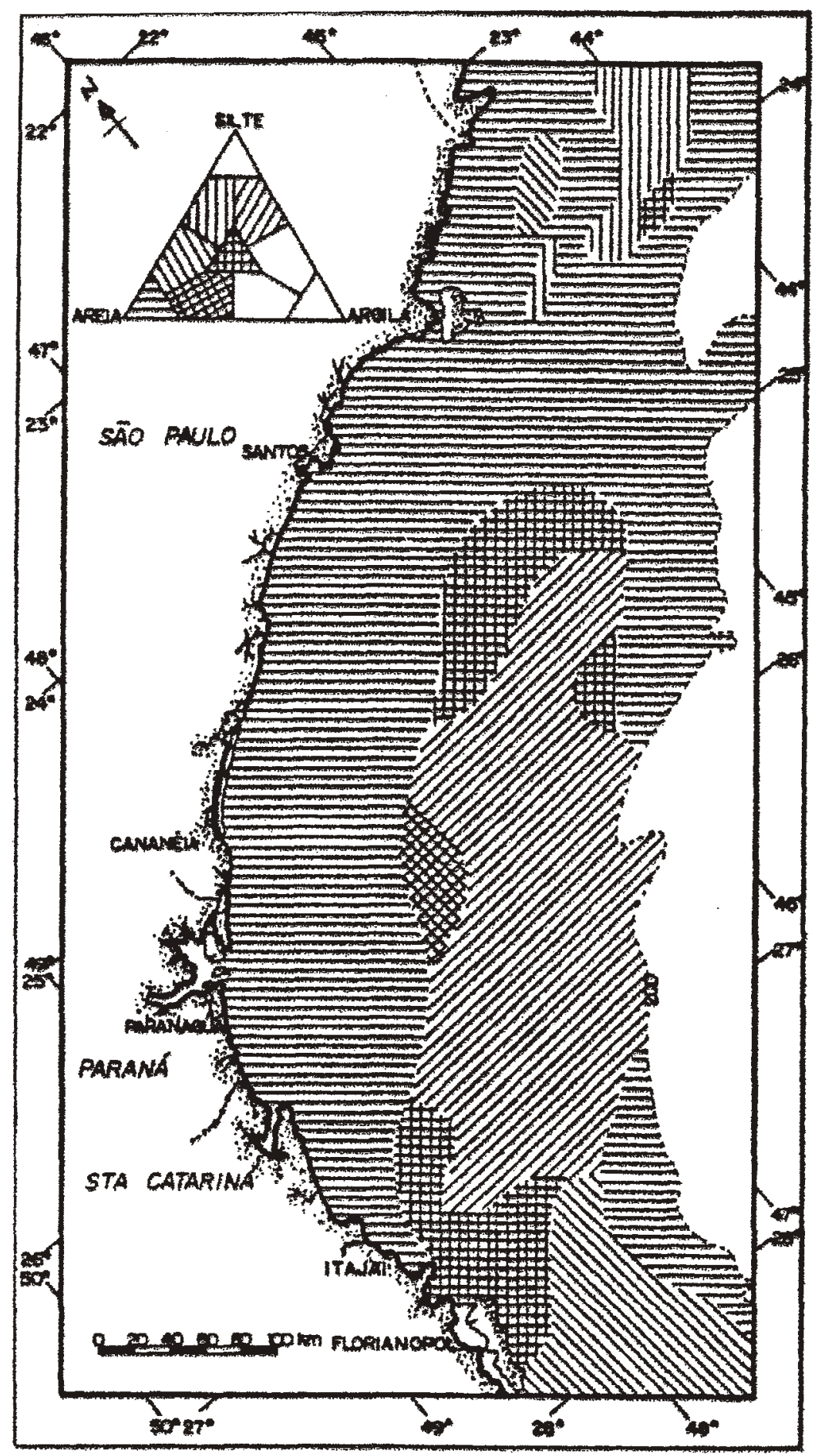

14. Mapa de fácies sedimentares da plataforma continental localizada entre os estados de São Paulo e Santa Catarina (Corrêa, 1979) 

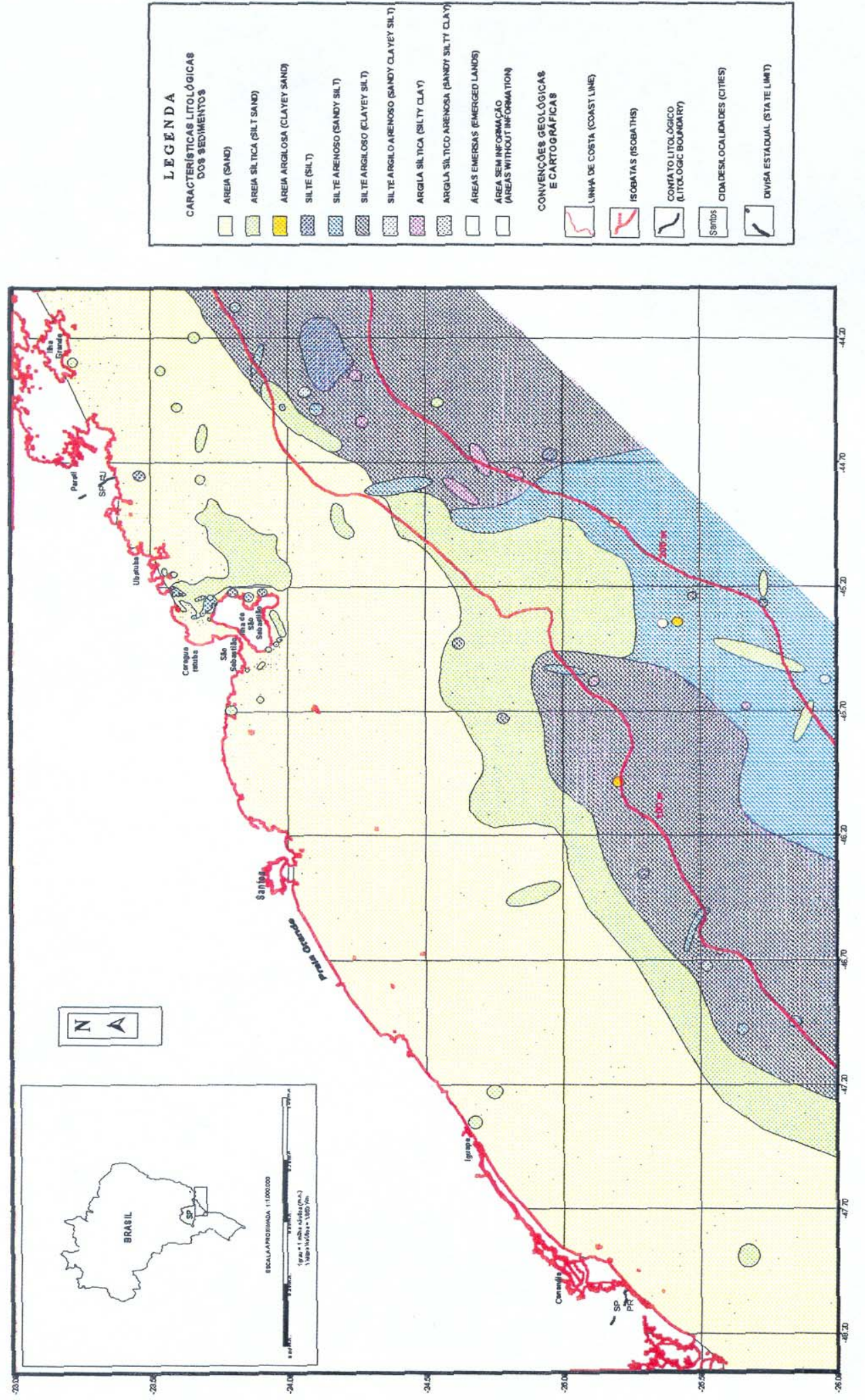

ำ

욲

되 일

을

竞 官

를

펀

흘 을

등

응

을 휼

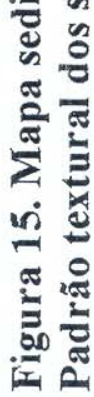



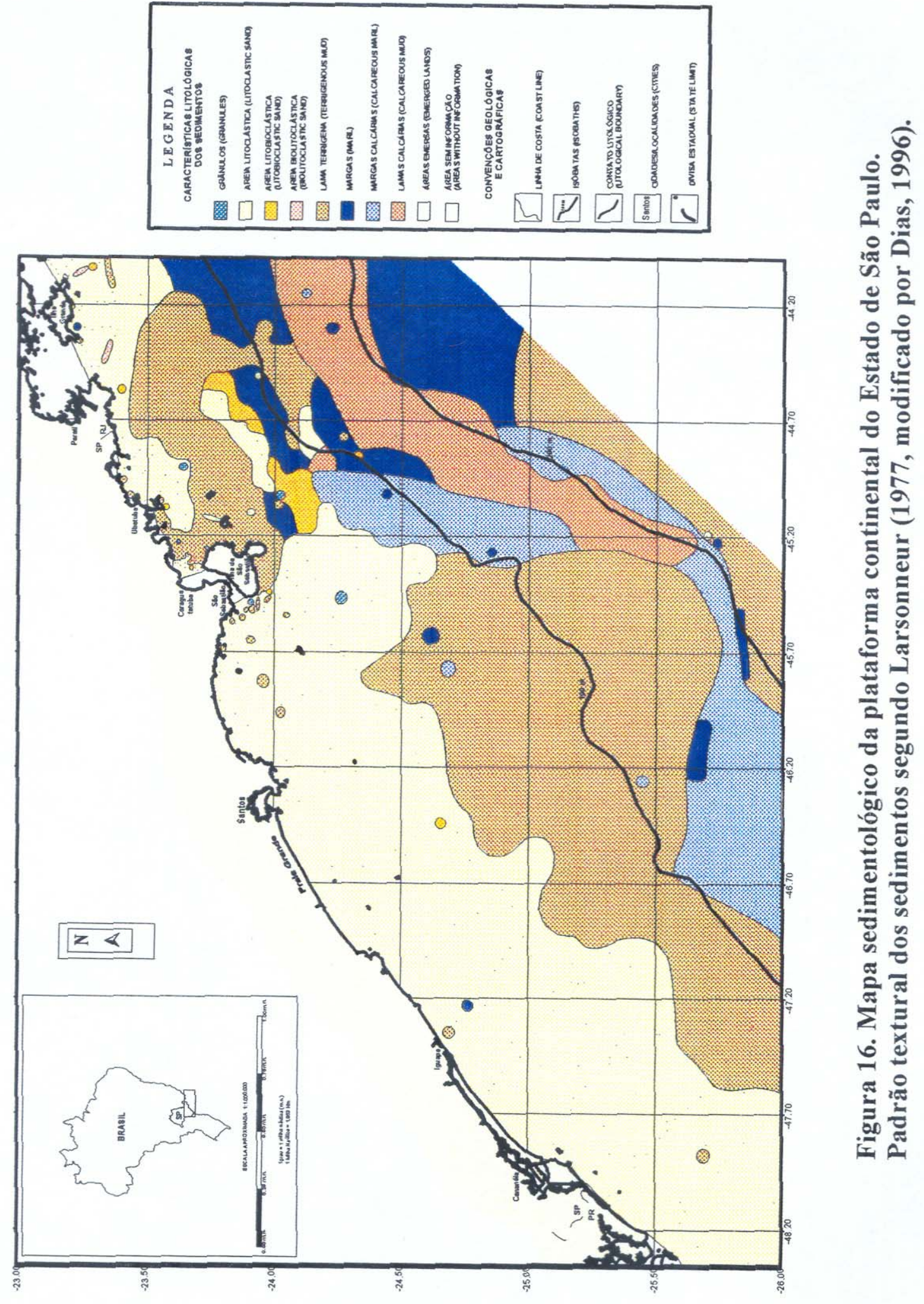

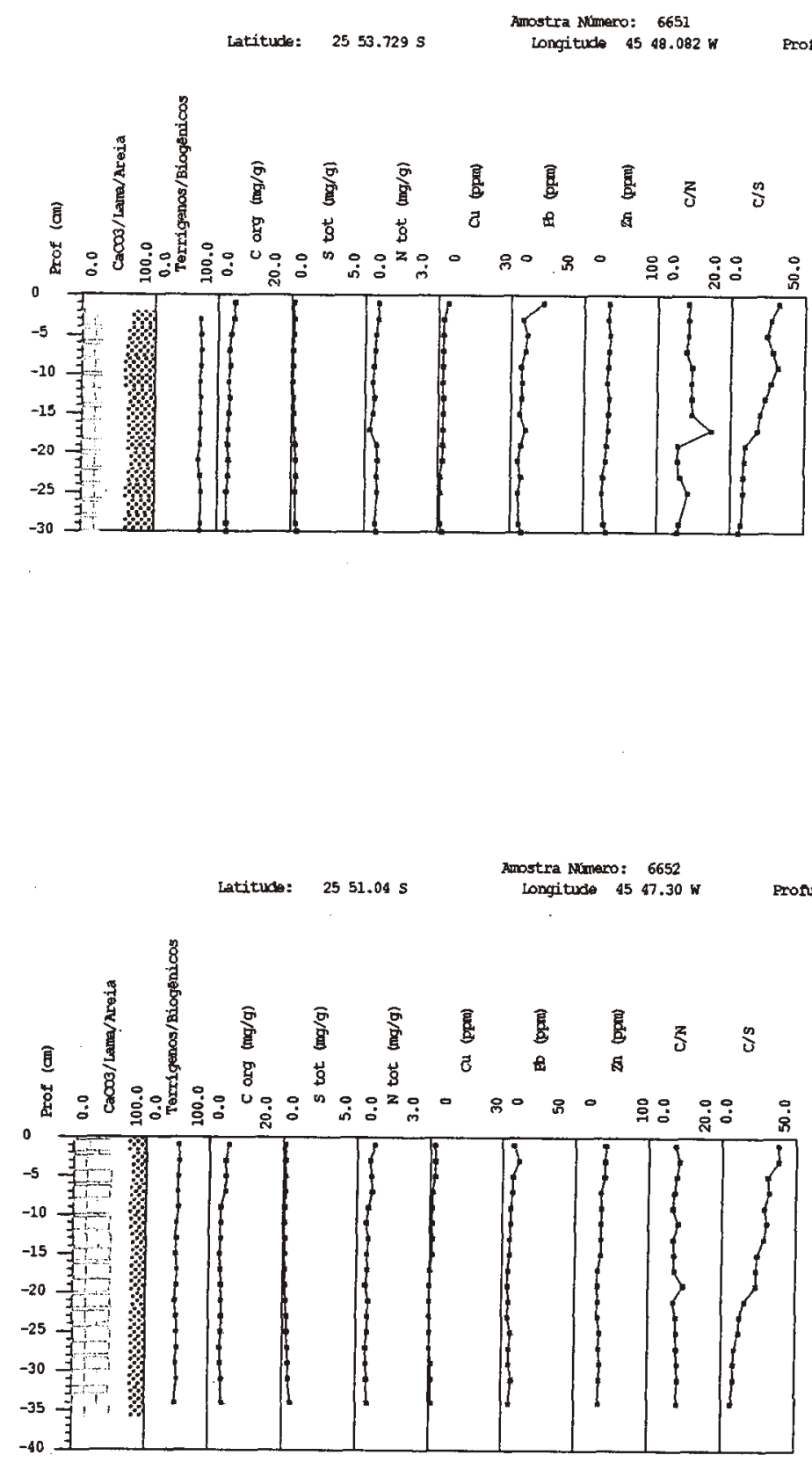

Figura 17. Variações dos parâmetros analisados ao longo dos testemunhos. 

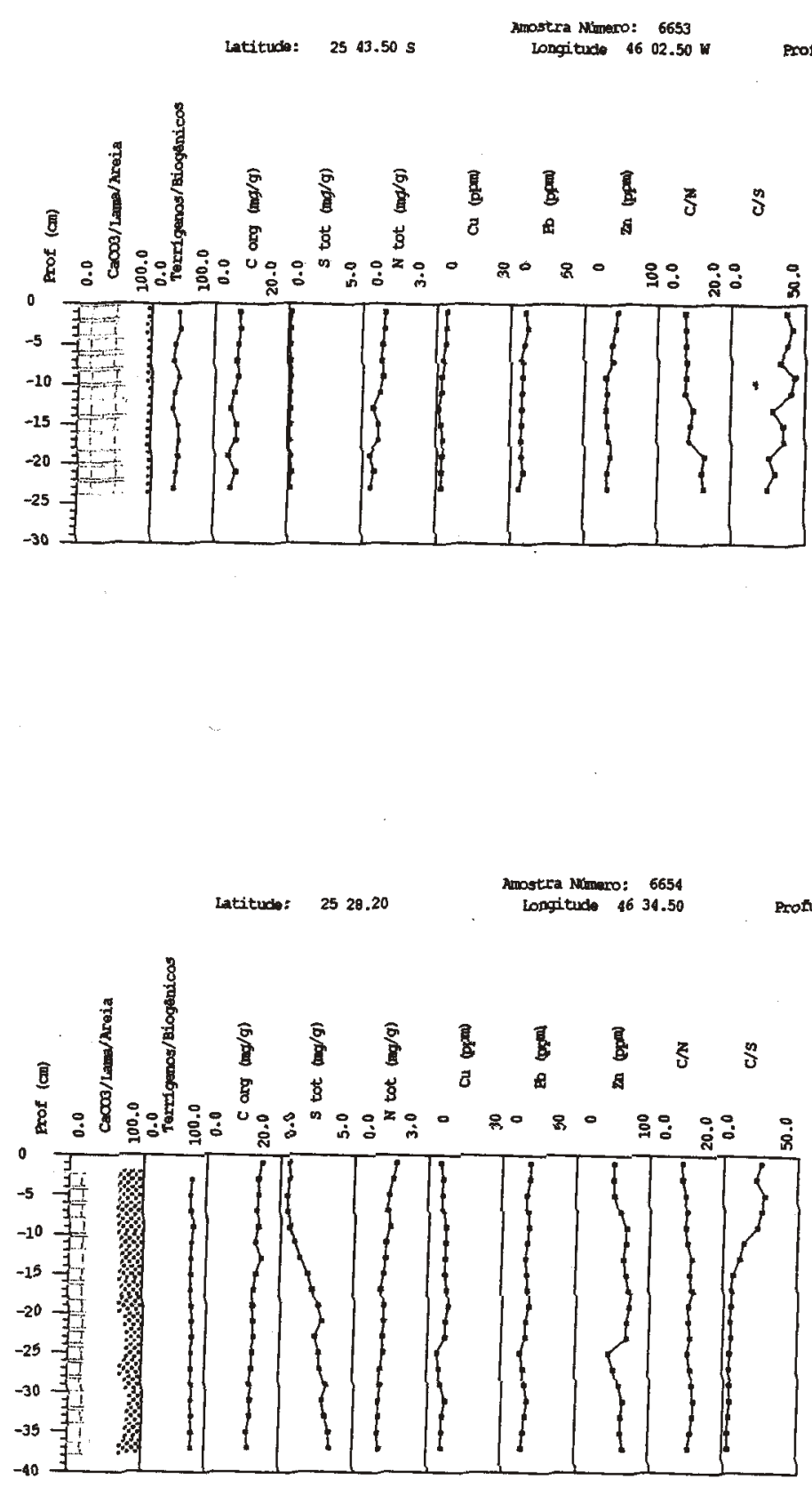

Figura 17. (cont.) 


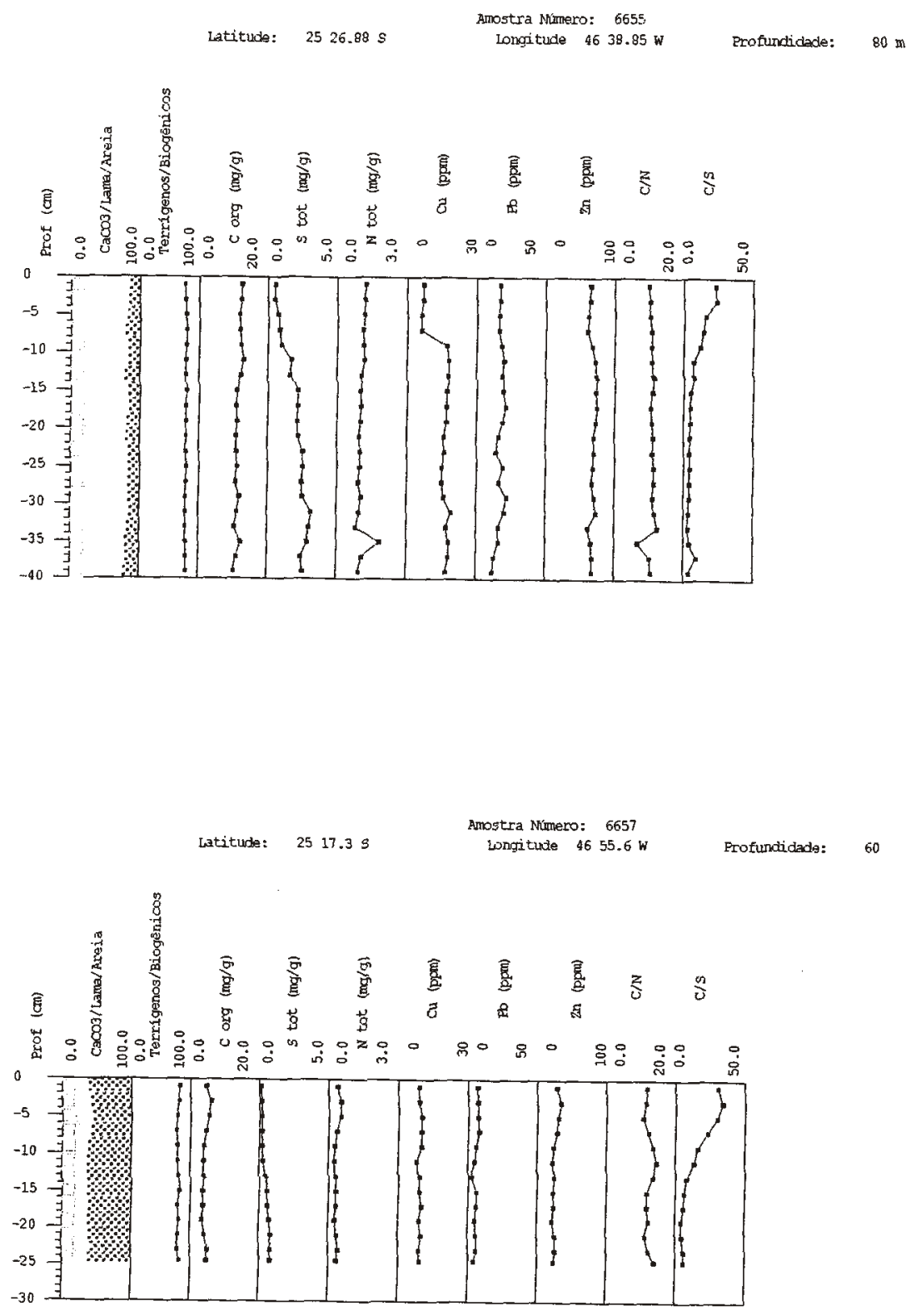

Figura 17. (cont.) 

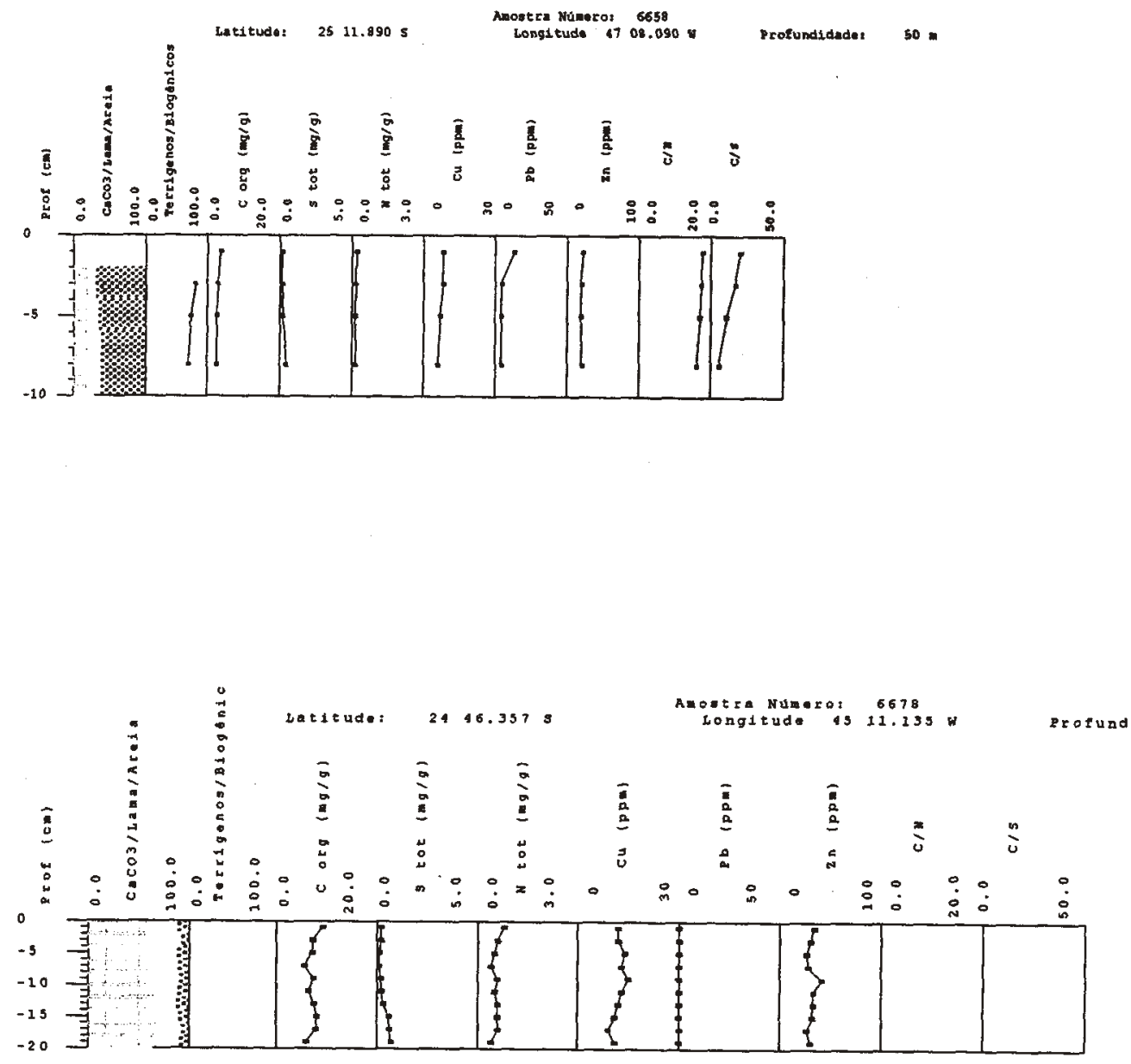

Figura 17. (cont.) 

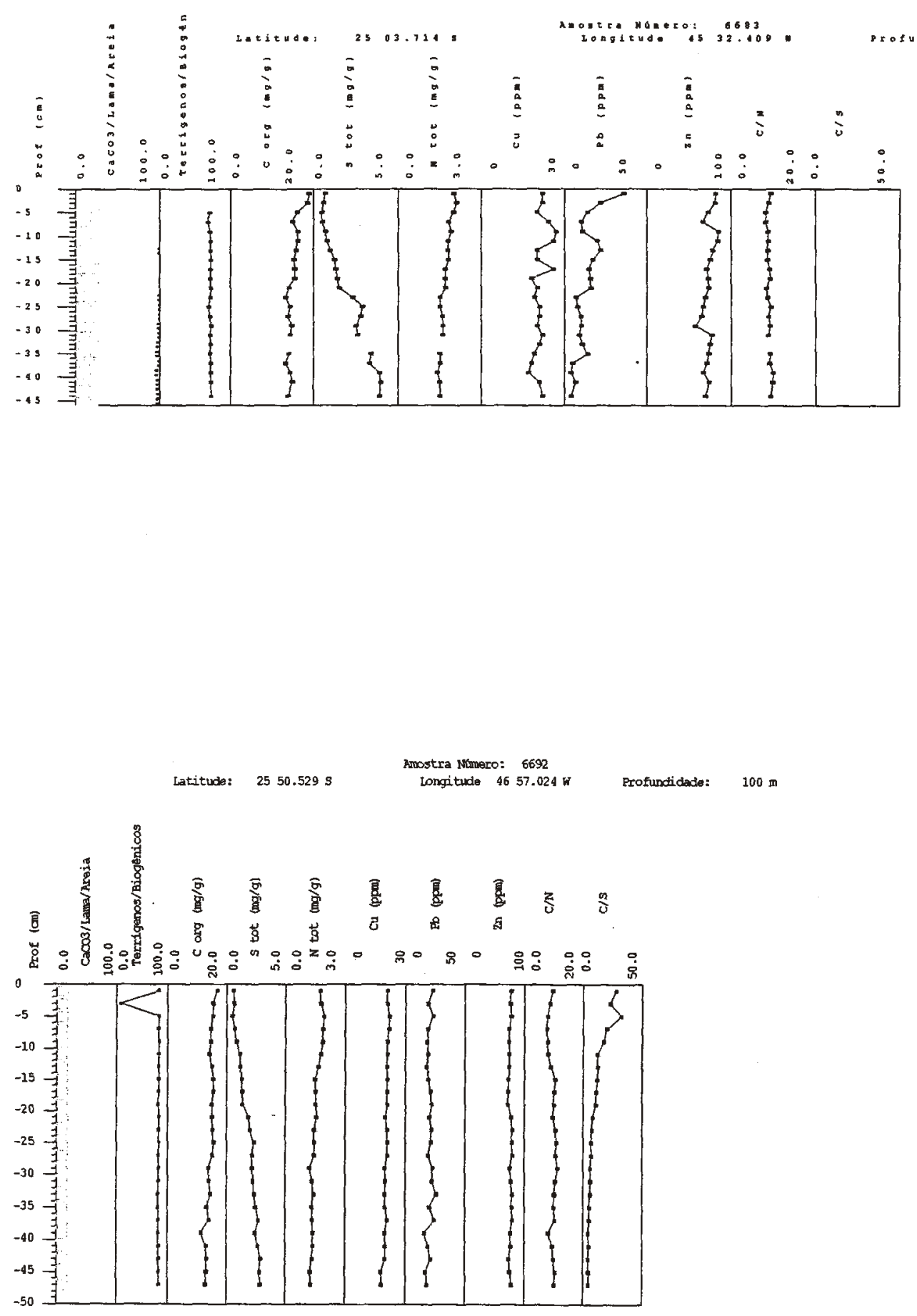

Figura 17. (cont.) 

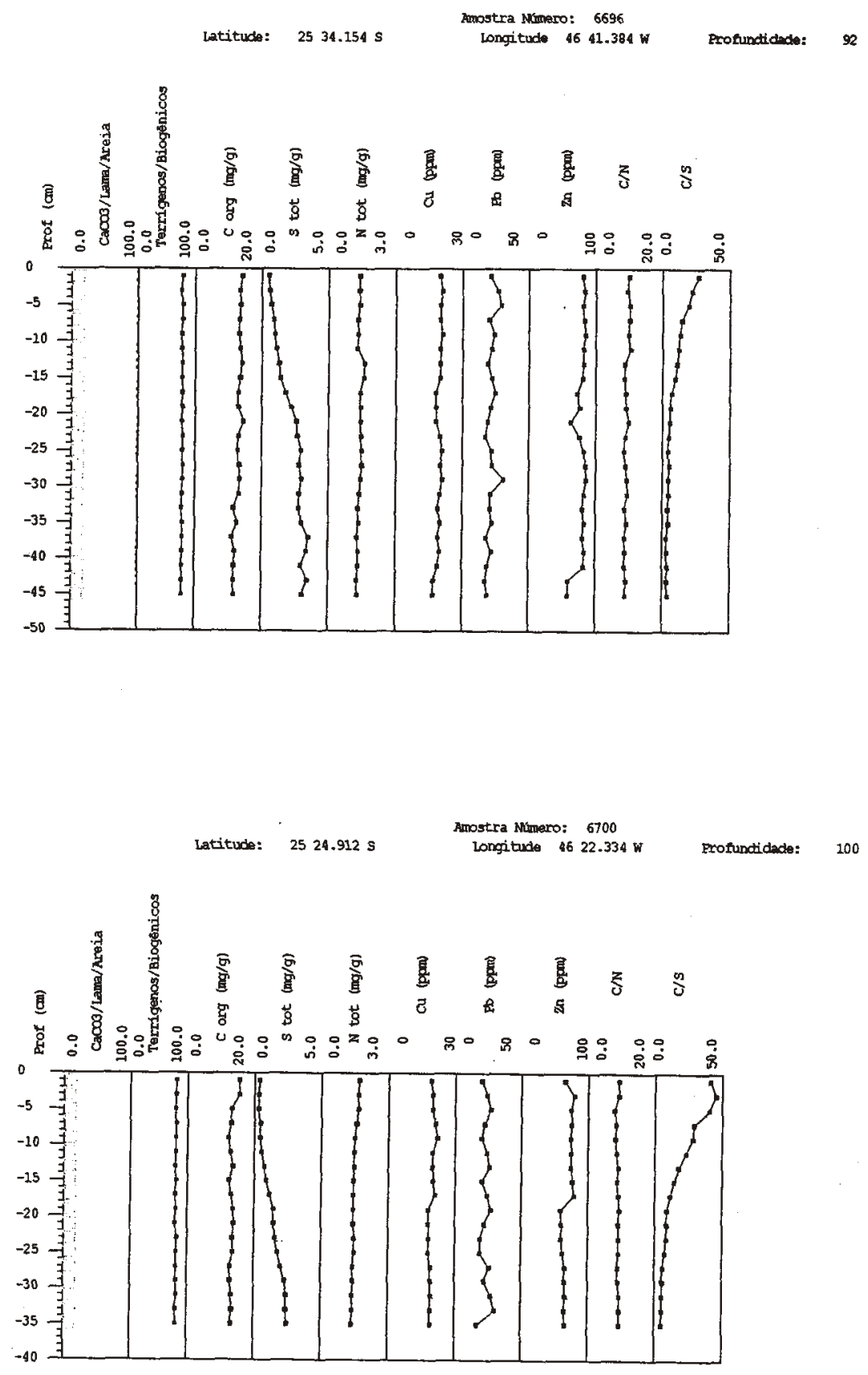

Figura 17. (cont.) 


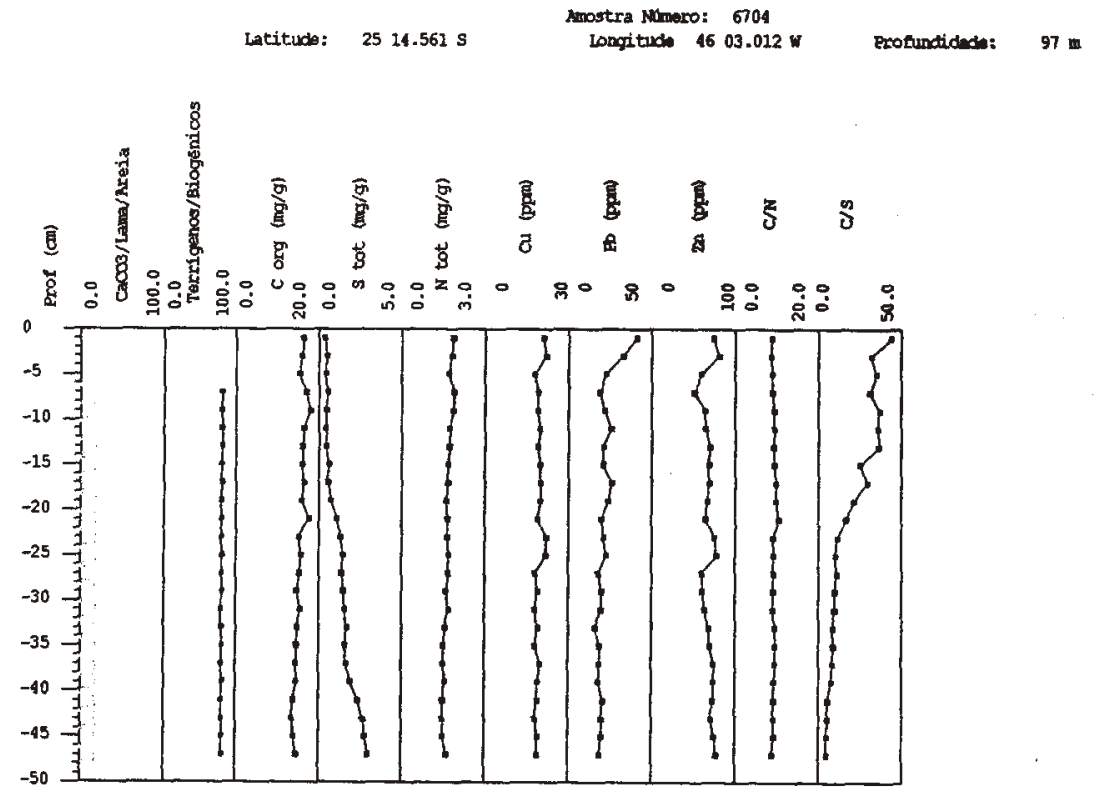

Figura 17. (cont.) 


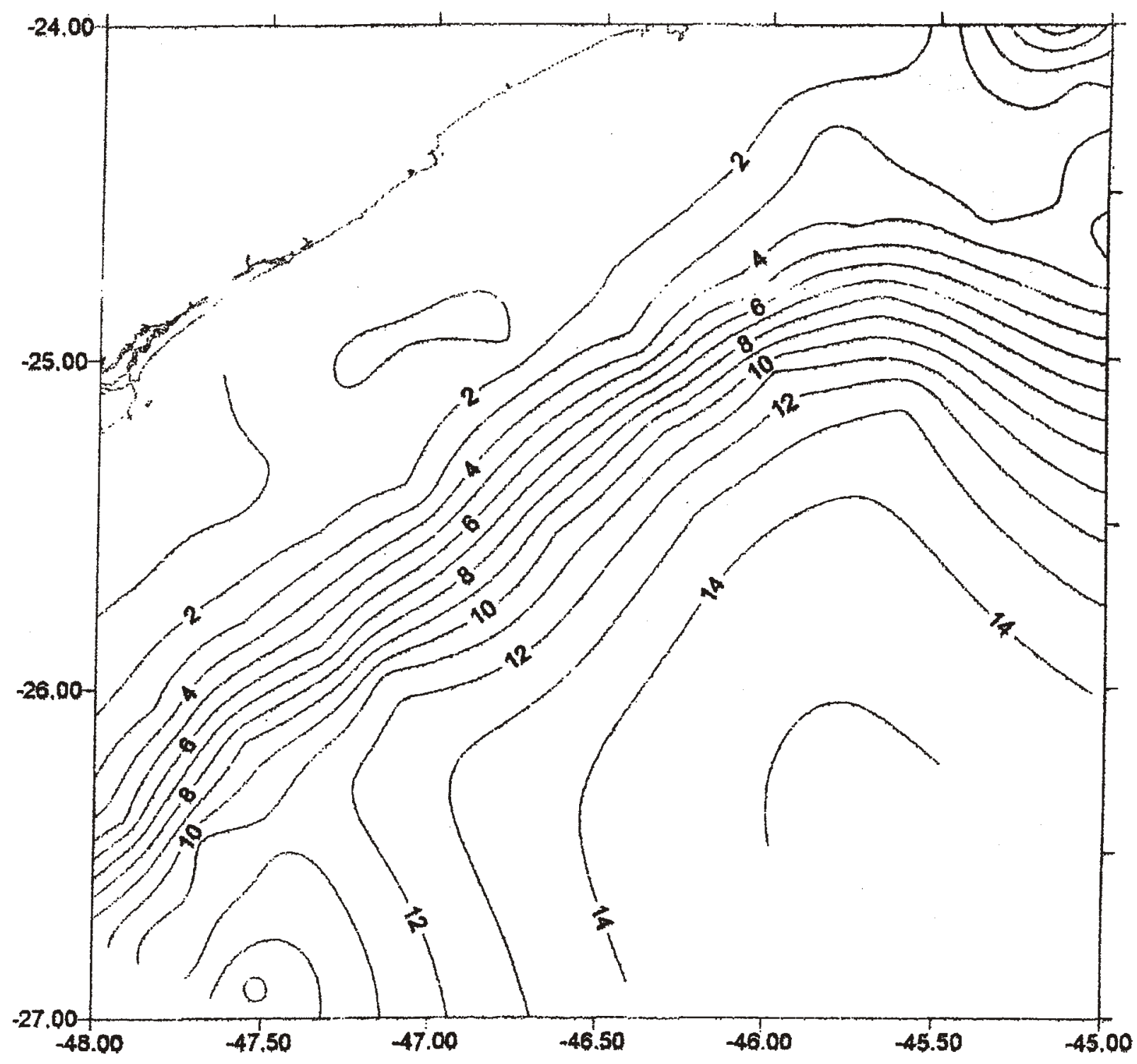

18. Variação espacial dos teores de Carbono orgânico $(\mathrm{mg} / \mathrm{g})$, na plataforma continental do Estado de Săo Paulo (Mahiques, 1998) 


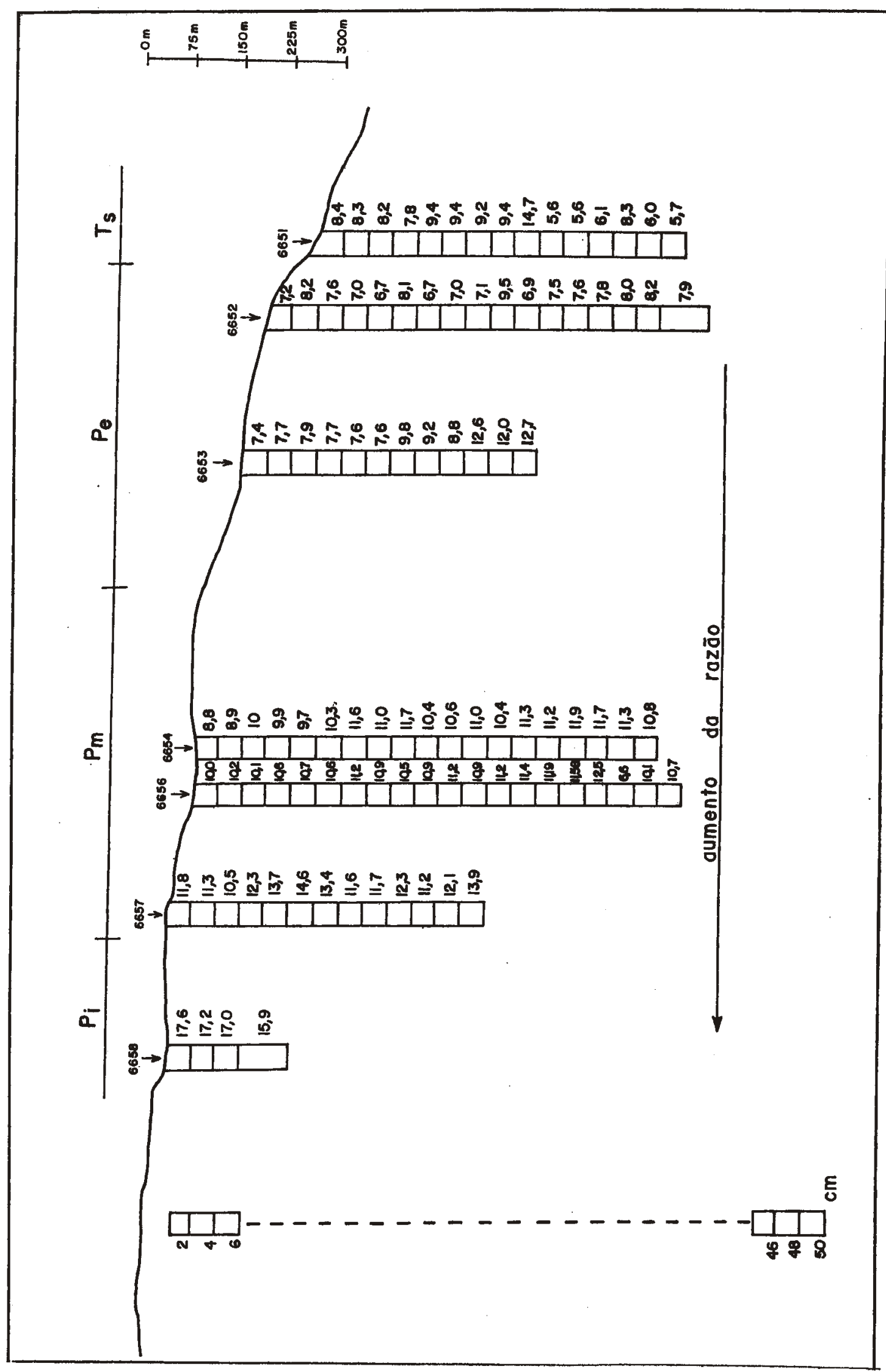

19. Razão C/N ( perfil 1 - NW/SE) 


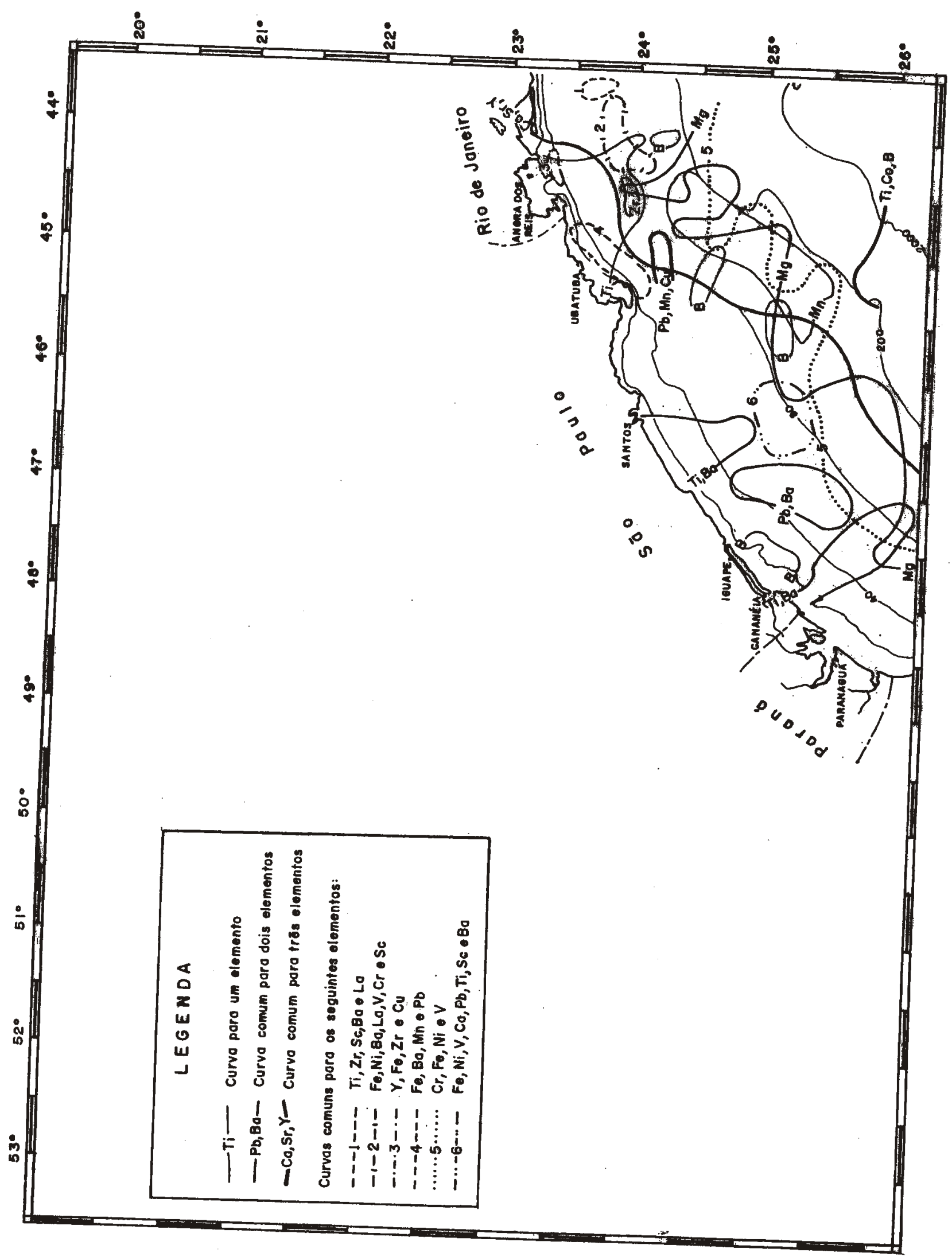

20. Mapeamento geoquímico. Plataforma continental sul do Estado de São Paulo. (Machado, 1985, CPRM). 

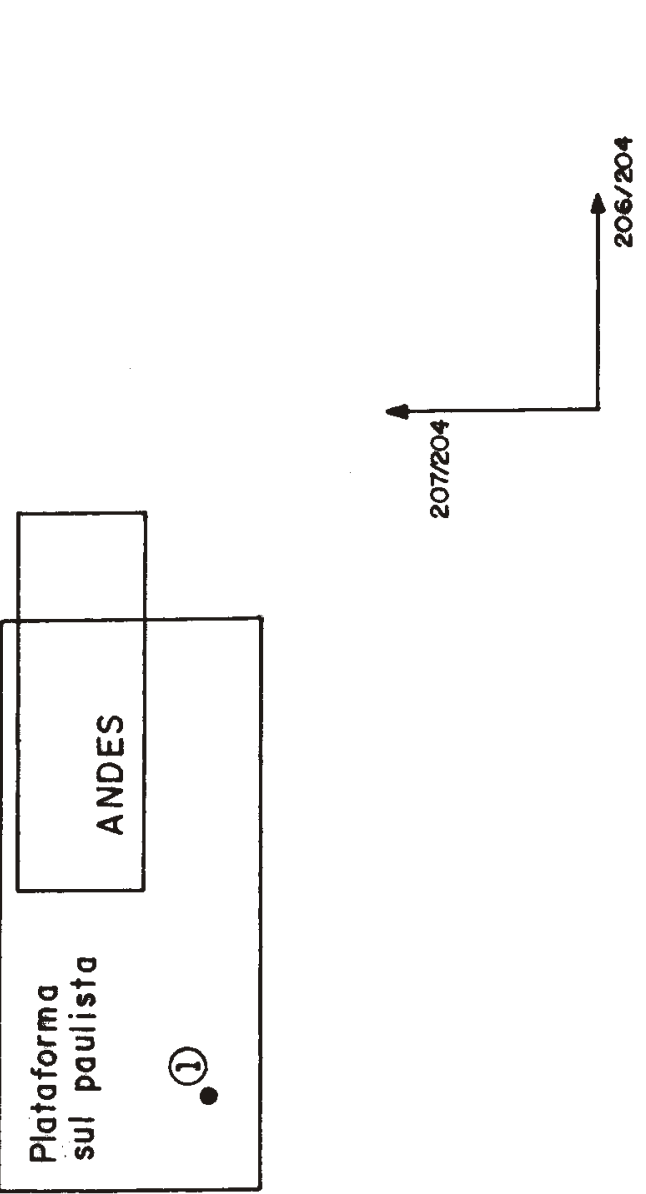

2
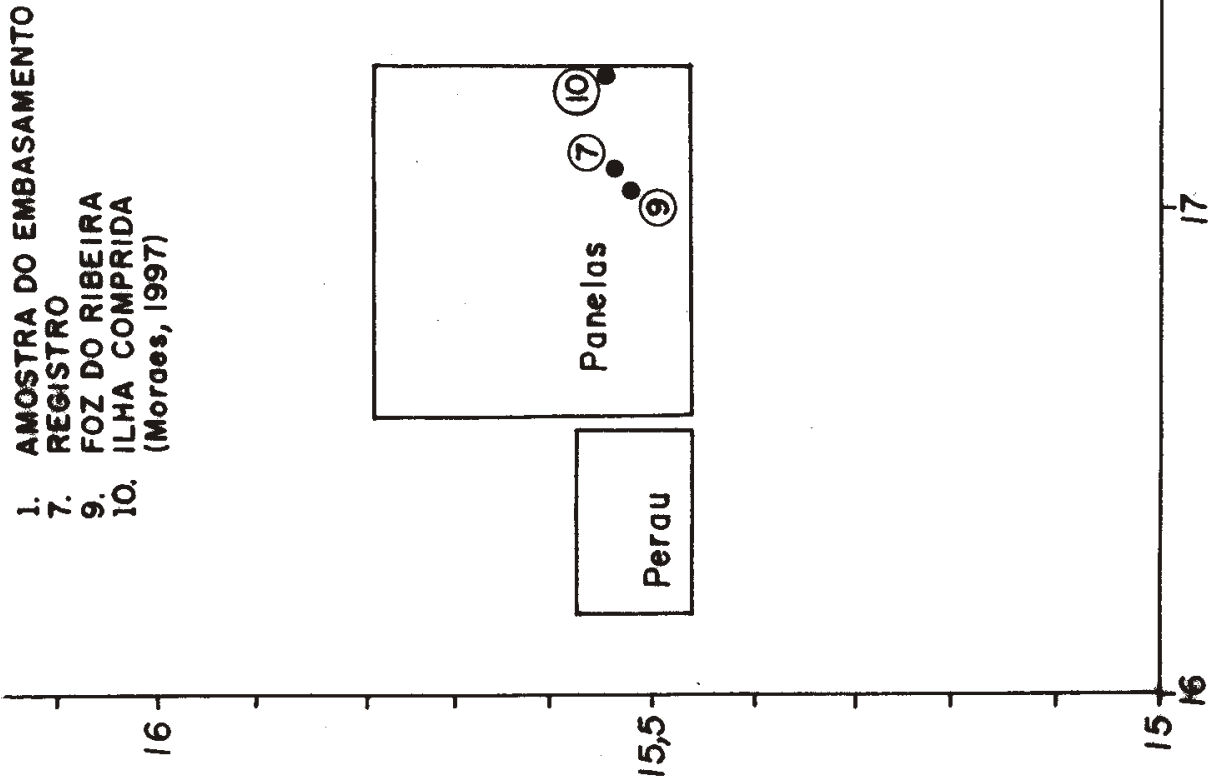

Figura 21 (a). Diagrama entre as razões isotópicas do chumbo (207/204 × 206/204) 

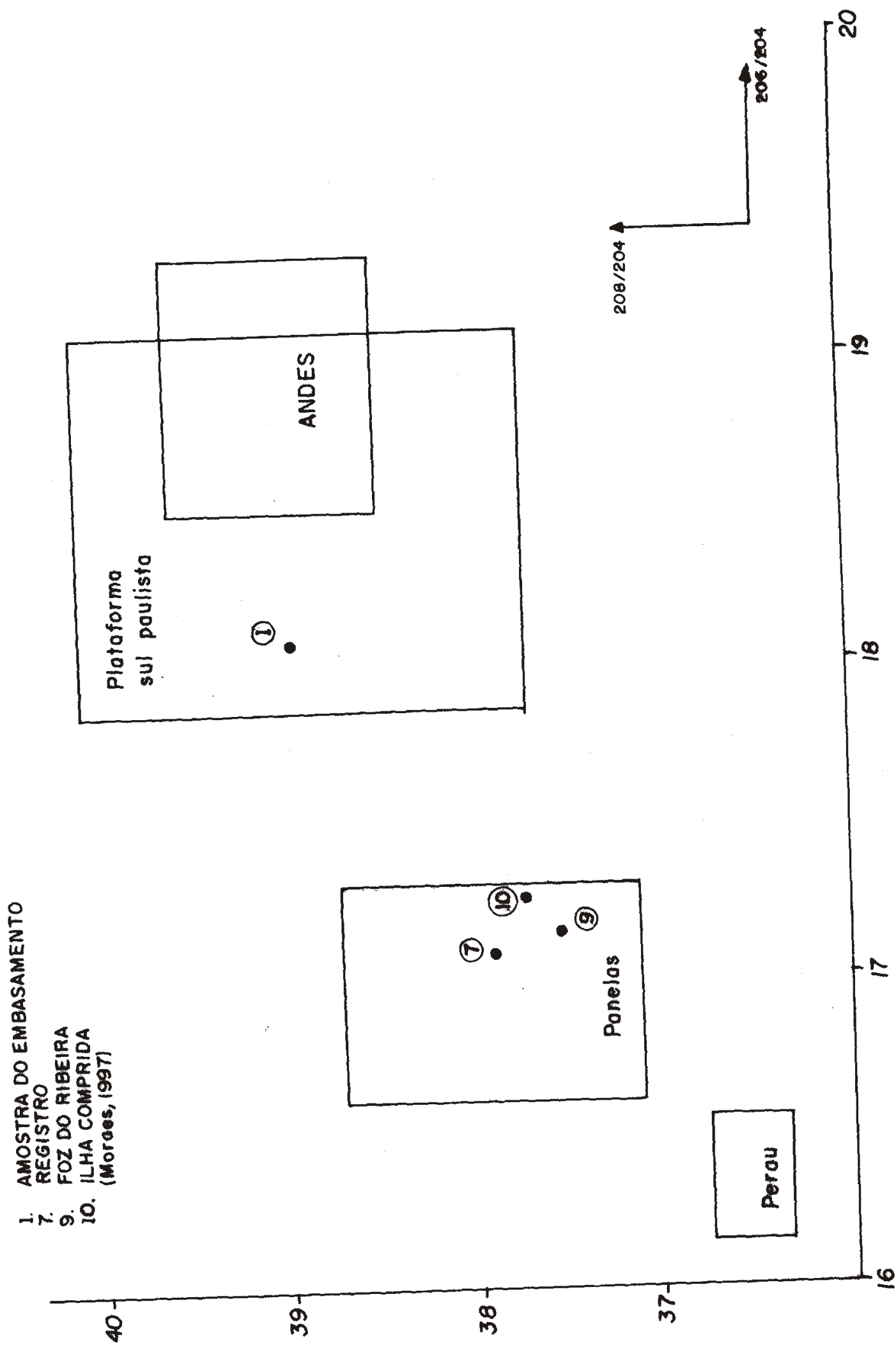

Figura 21 (b). Diagrama entre as razões isotópicas do chumbo (208/204 × 206/204) 

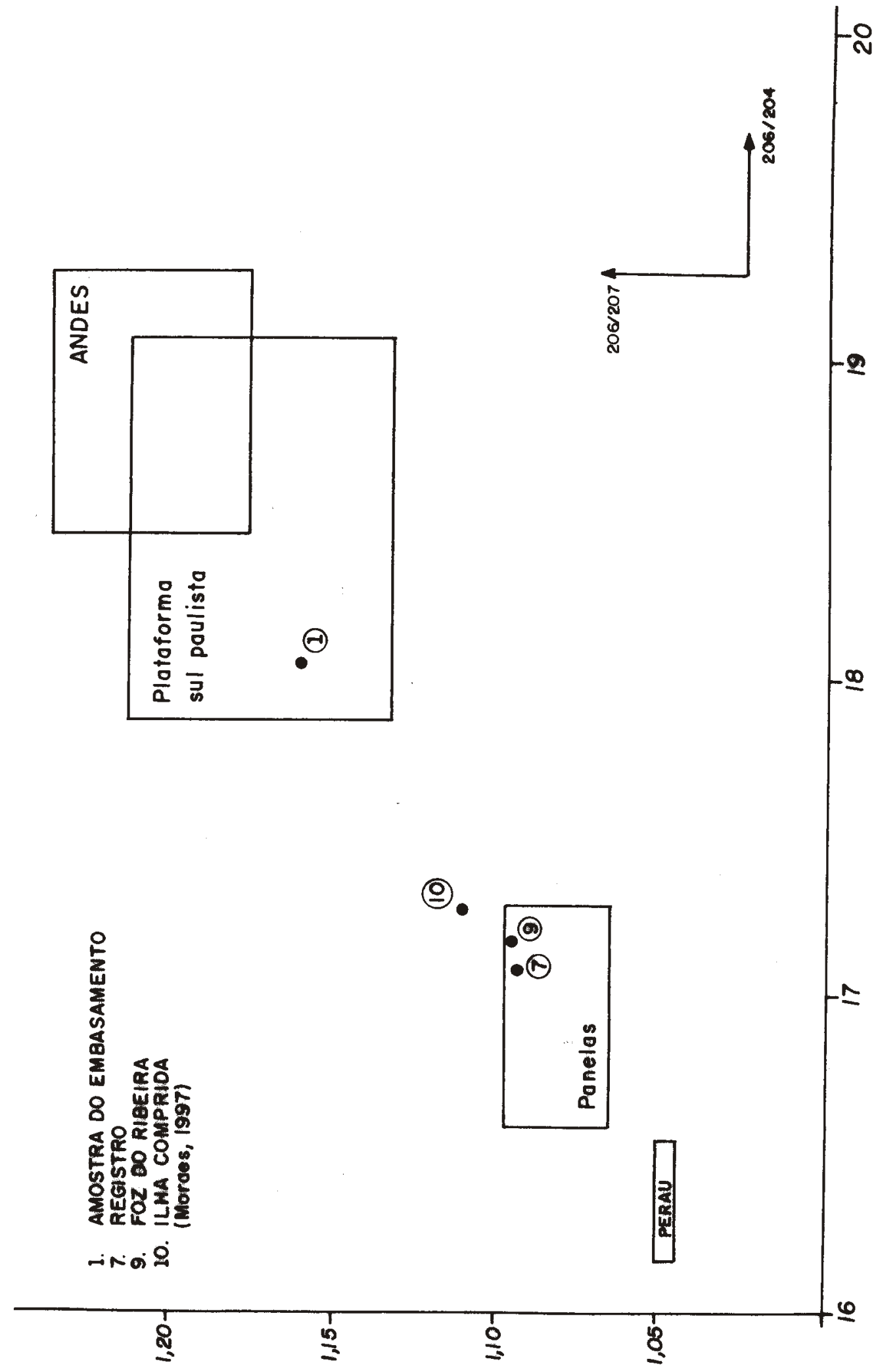

Figura 21 (c). Diagrama entre as razões isotópicas do chumbo (206/207 × 206/204) 


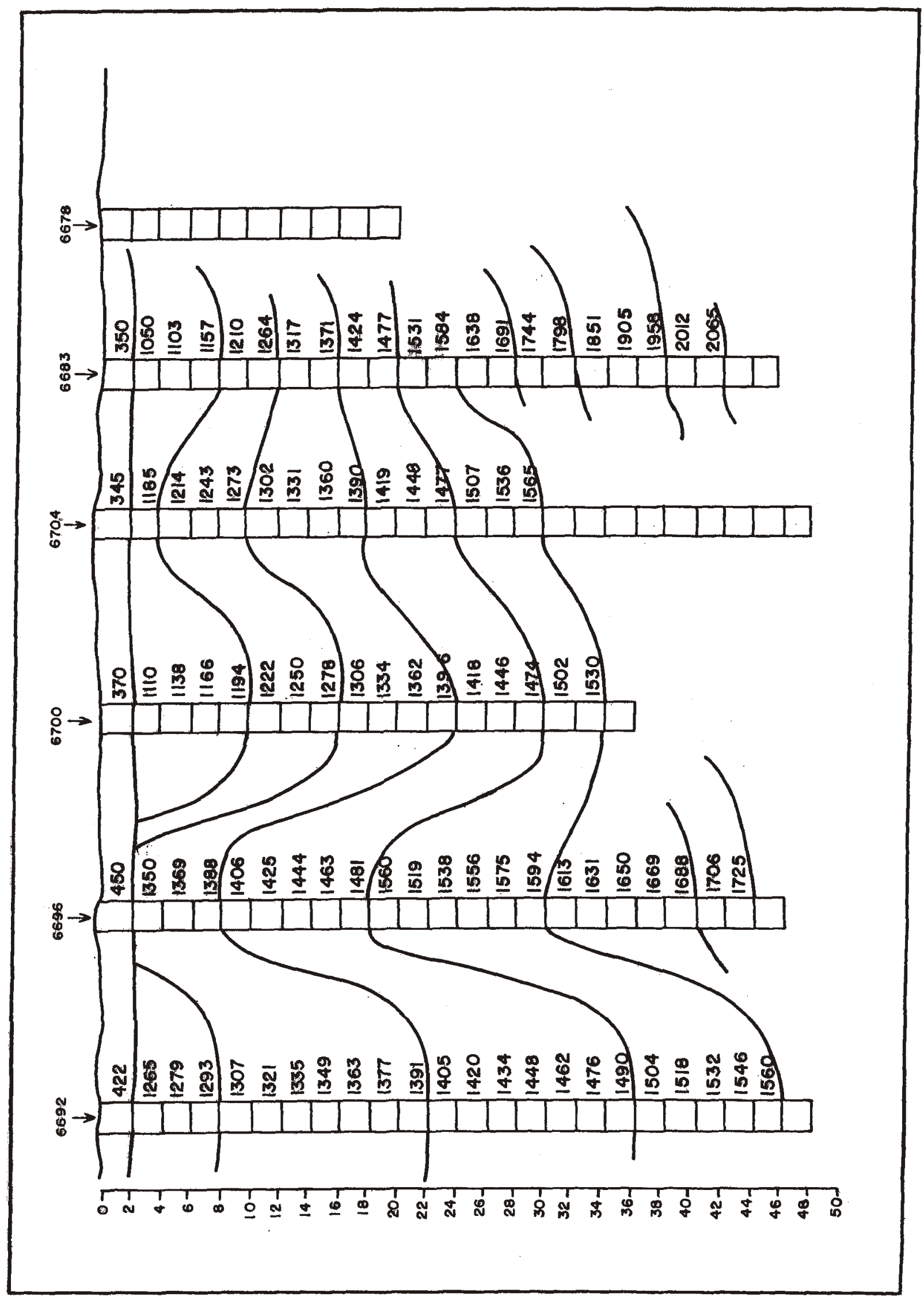

22. Idades interpoladas ${ }^{14} \mathrm{C}$. Perfil 100 metros. 


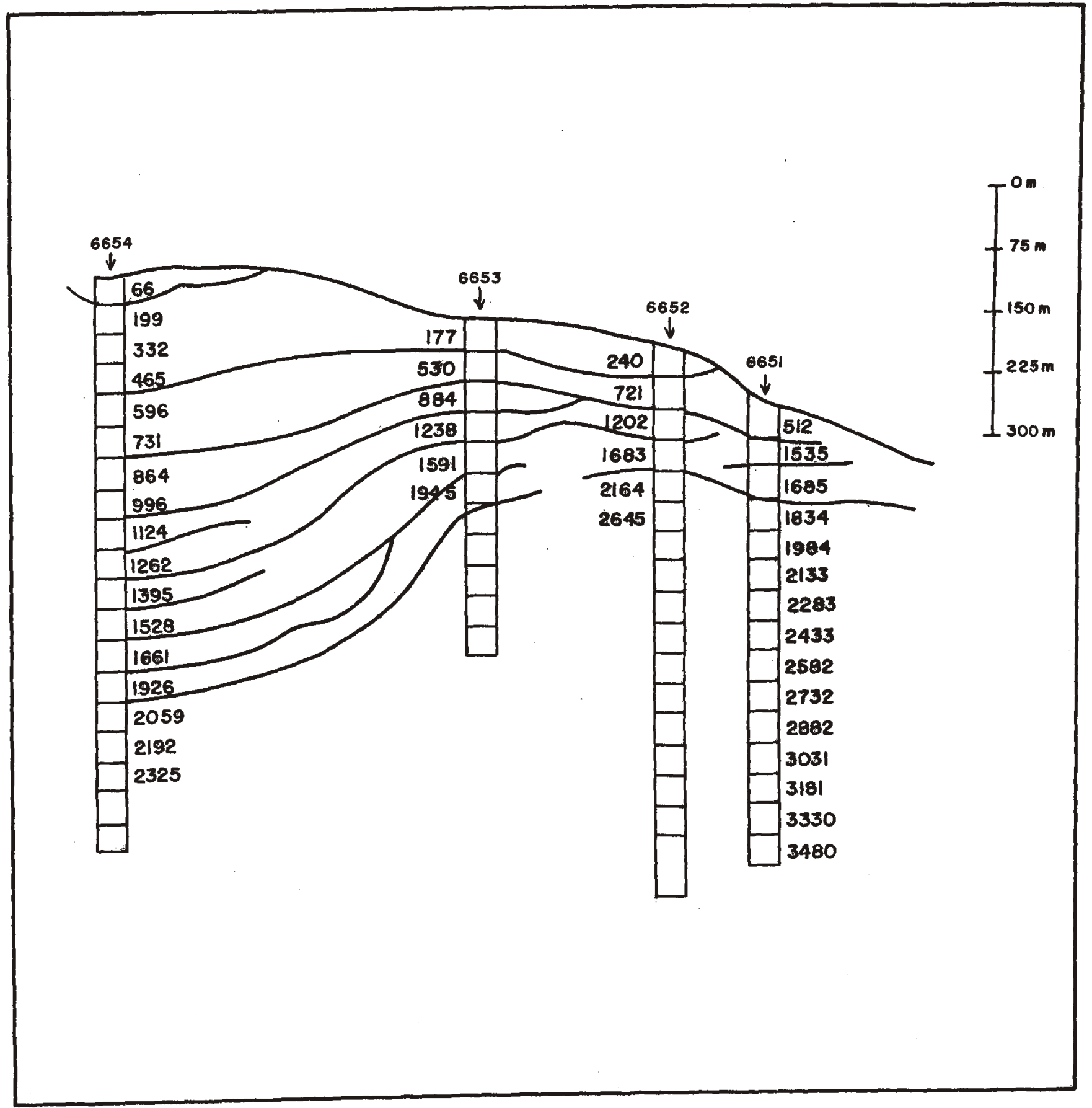

23. Idades interpoladas ${ }^{14} \mathrm{C}$. Perfil transversal à costa 


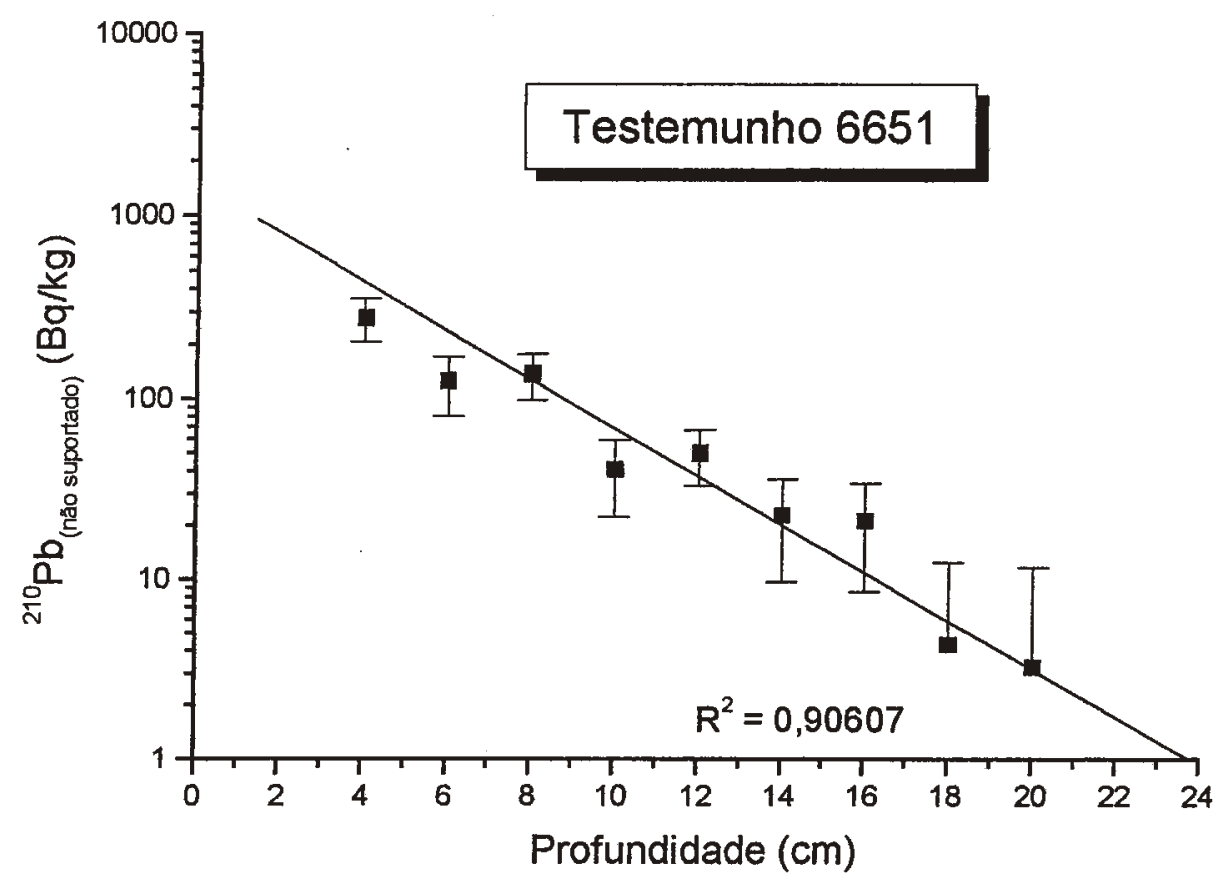

Figura 24: Gráfico ajustado da concentração de ${ }^{210} \mathrm{~Pb}_{\text {não suportado }}$ em função da profundidade para $\mathrm{o}$ testemunho 6651 .

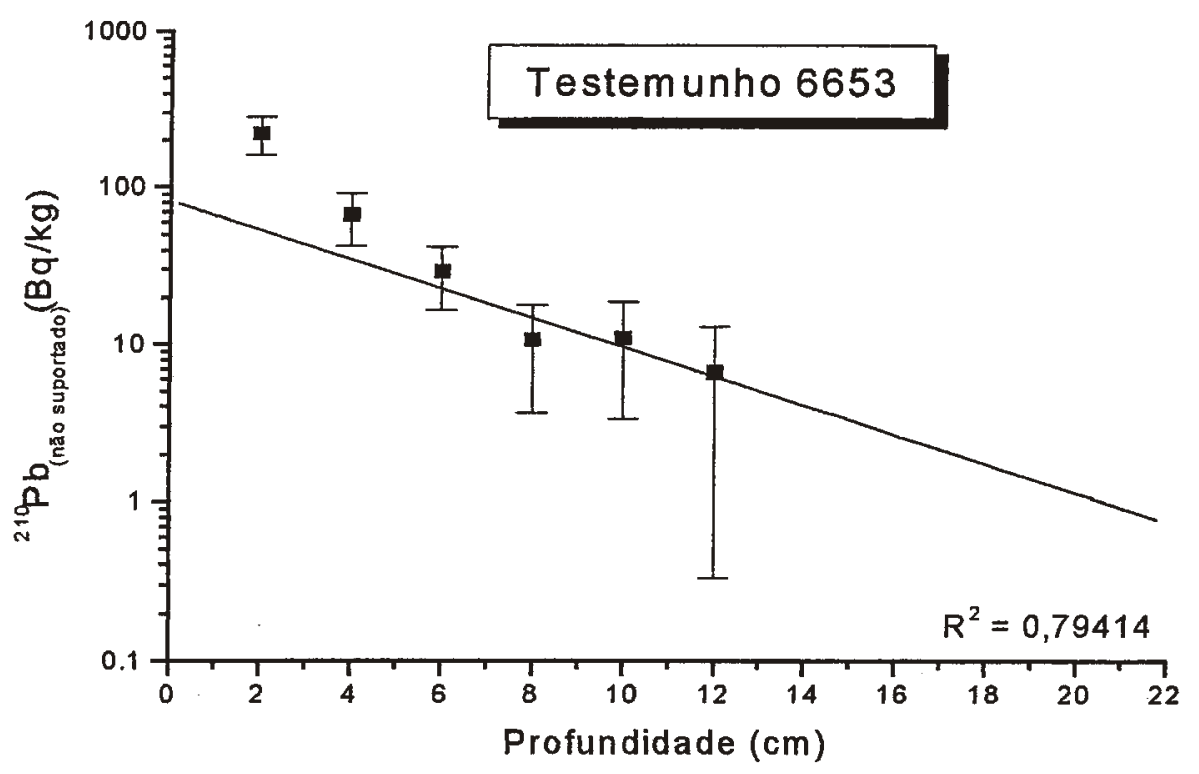

Figura 25: Gráfico ajustado da concentração de ${ }^{210} \mathrm{~Pb}_{\text {não suportado }}$ em função da profundidade para $\mathrm{o}$ testemunho 6653. 


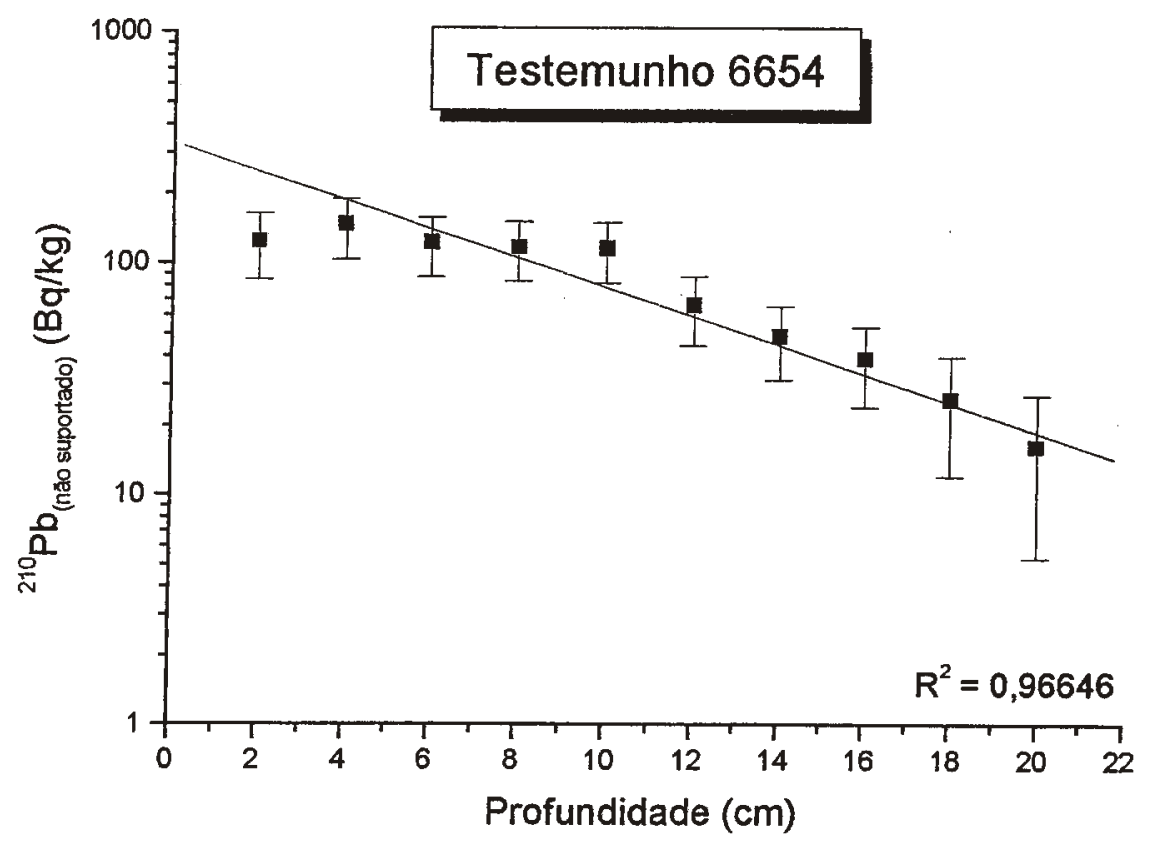

Figura 26: Gráfico ajustado da concentração de ${ }^{210} \mathrm{~Pb}_{\text {não suportado }}$ em função da profundidade para o testemunho 6654 .

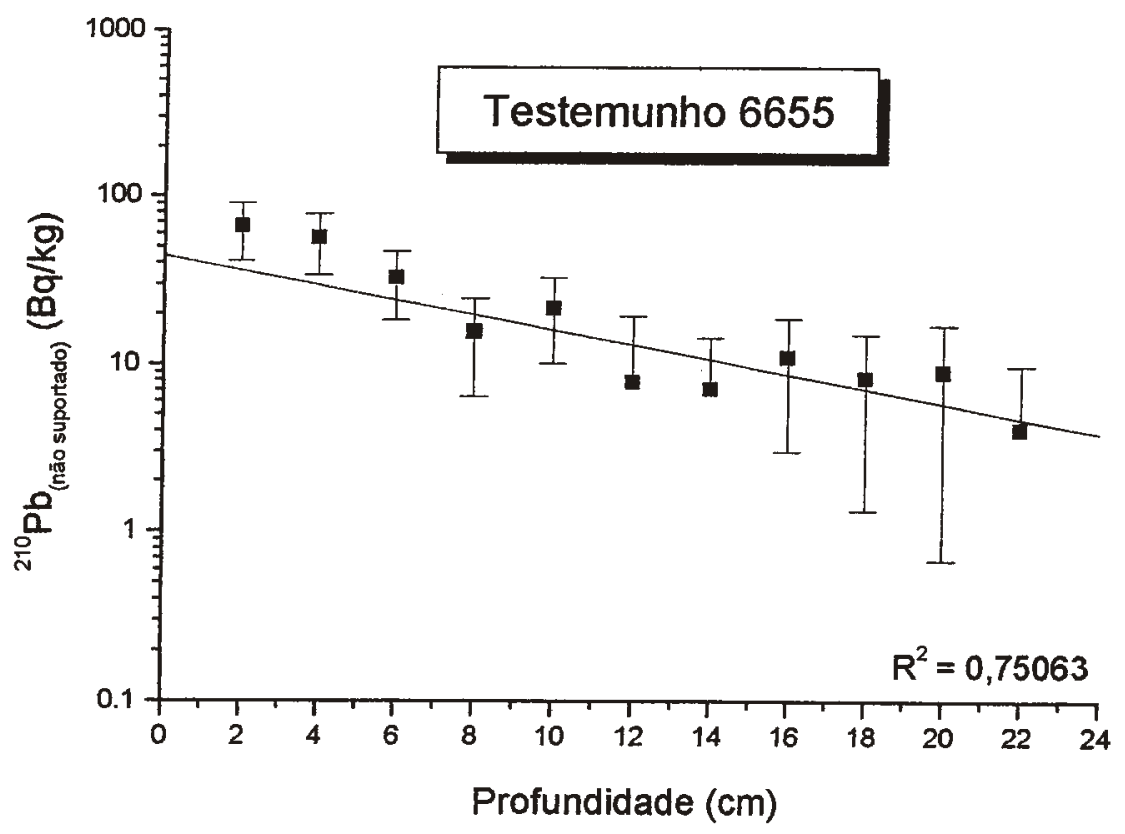

Figura 27: Gráfico ajustado da concentração de ${ }^{210} \mathrm{~Pb}_{\text {não suportado }}$ em função da profundidade para o testemunho 6655 . 


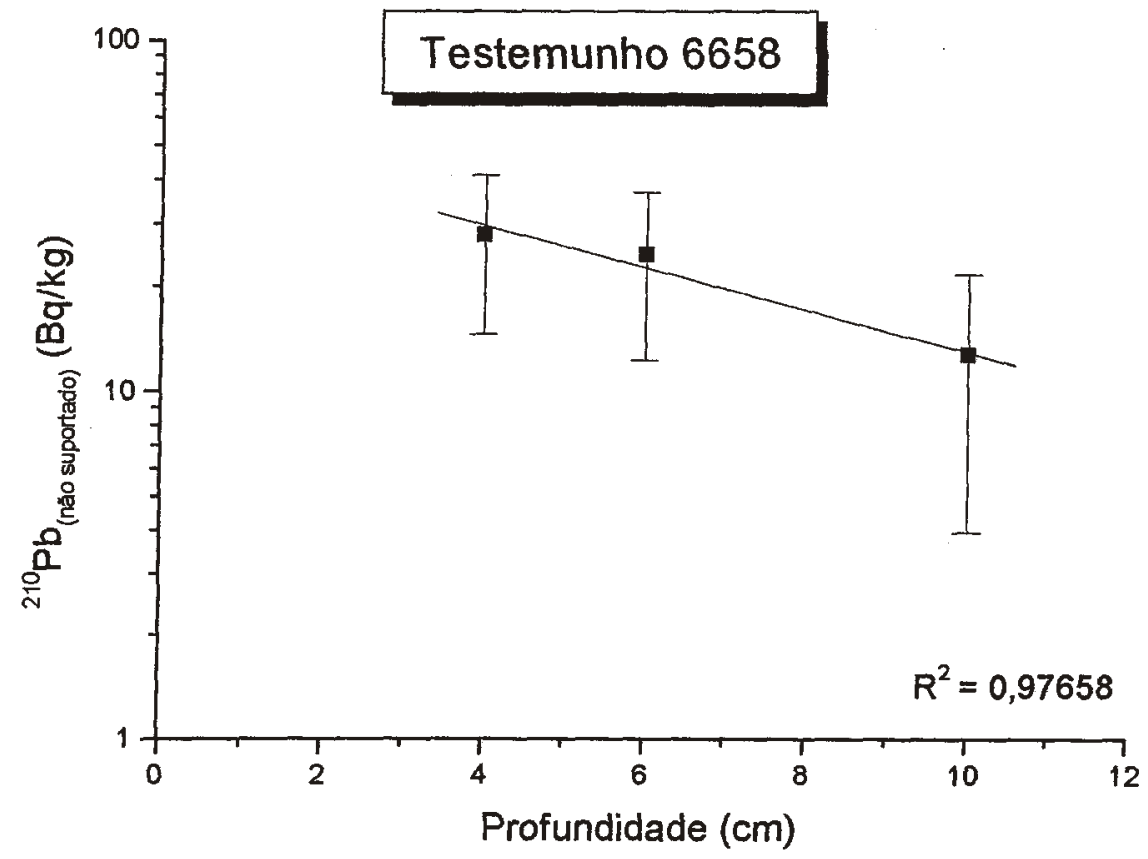

Figura 28: Gráfico ajustado da concentração de ${ }^{210} \mathrm{~Pb}_{\text {não suportado }}$ em função da profundidade para o testemunho 6658 .

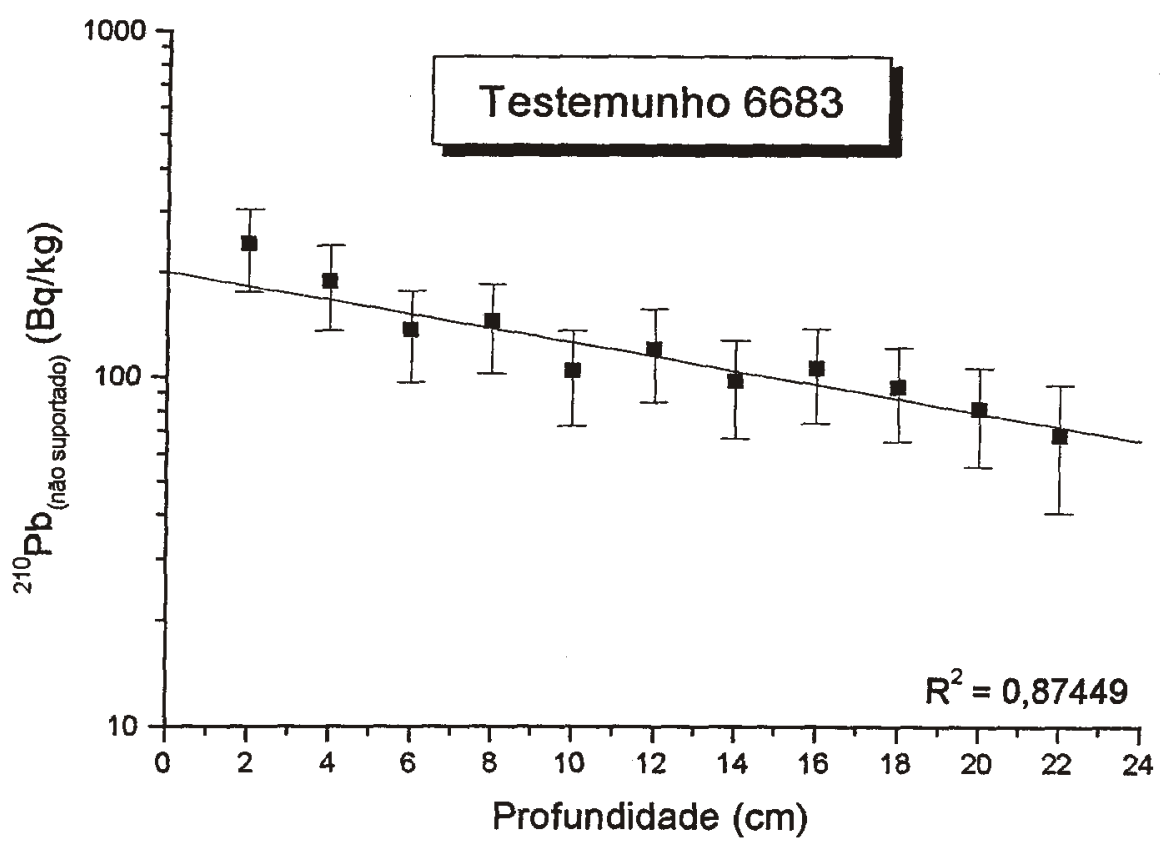

Figura 29: Gráfico ajustado da concentração de ${ }^{210} \mathrm{~Pb}_{\text {não suportado }}$ em função da profundidade para 0 testemunho $6683(0-22 \mathrm{~cm})$. 


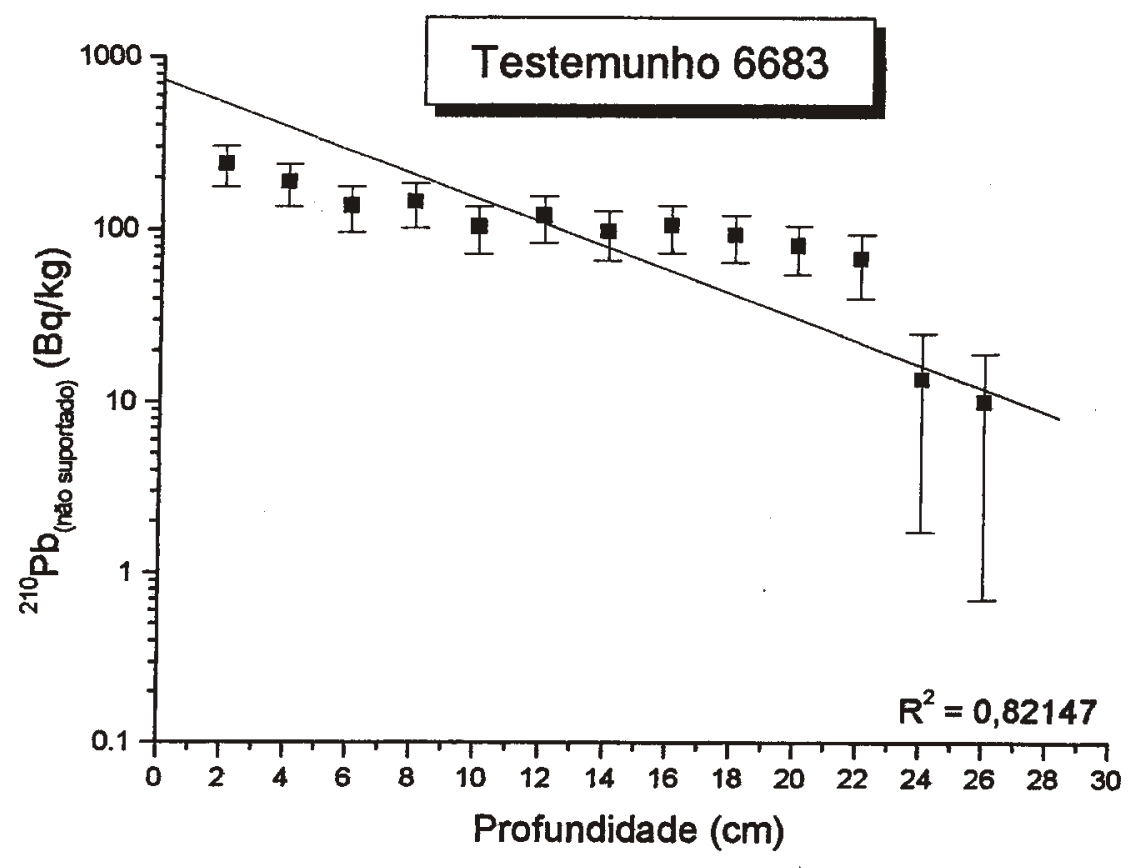

Figura 30: Gráfico ajustado da concentração de ${ }^{210} \mathrm{~Pb}_{\text {não suportado }}$ em função da profundidade para o testemunho $6683(0-28 \mathrm{~cm})$.

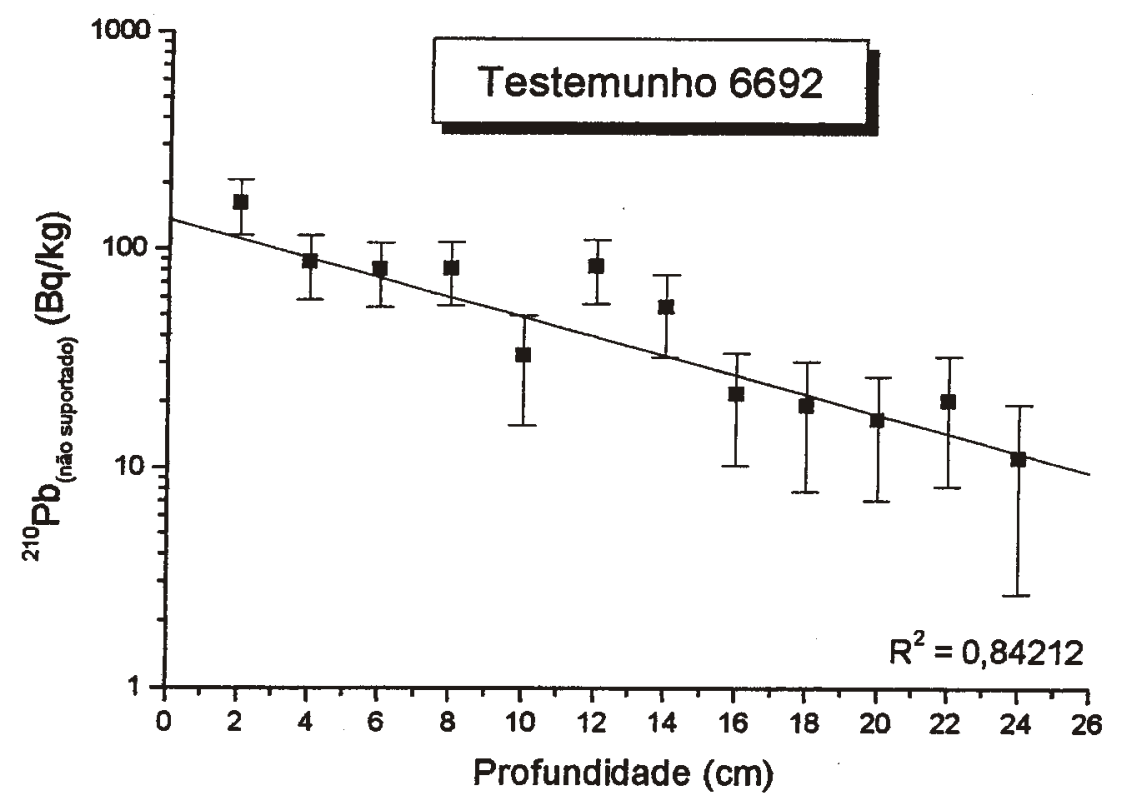

Figura 31: Gráfico ajustado da concentração de ${ }^{210} \mathrm{~Pb}_{\text {nåo suportado }}$ em função da profundidade para 0 testemunho 6692. 


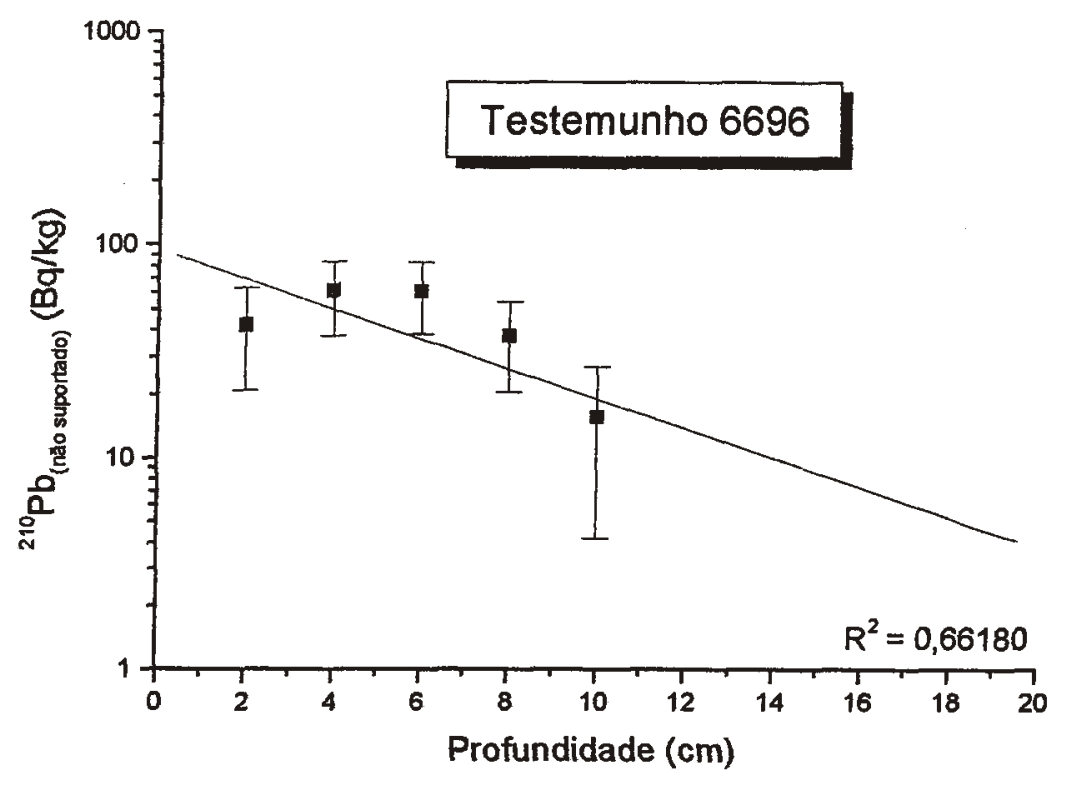

Figura 32: Gráfico ajustado da concentração de ${ }^{210} \mathrm{~Pb}_{\text {não suportado }}$ em função da profundidade para o testemunho 6696.

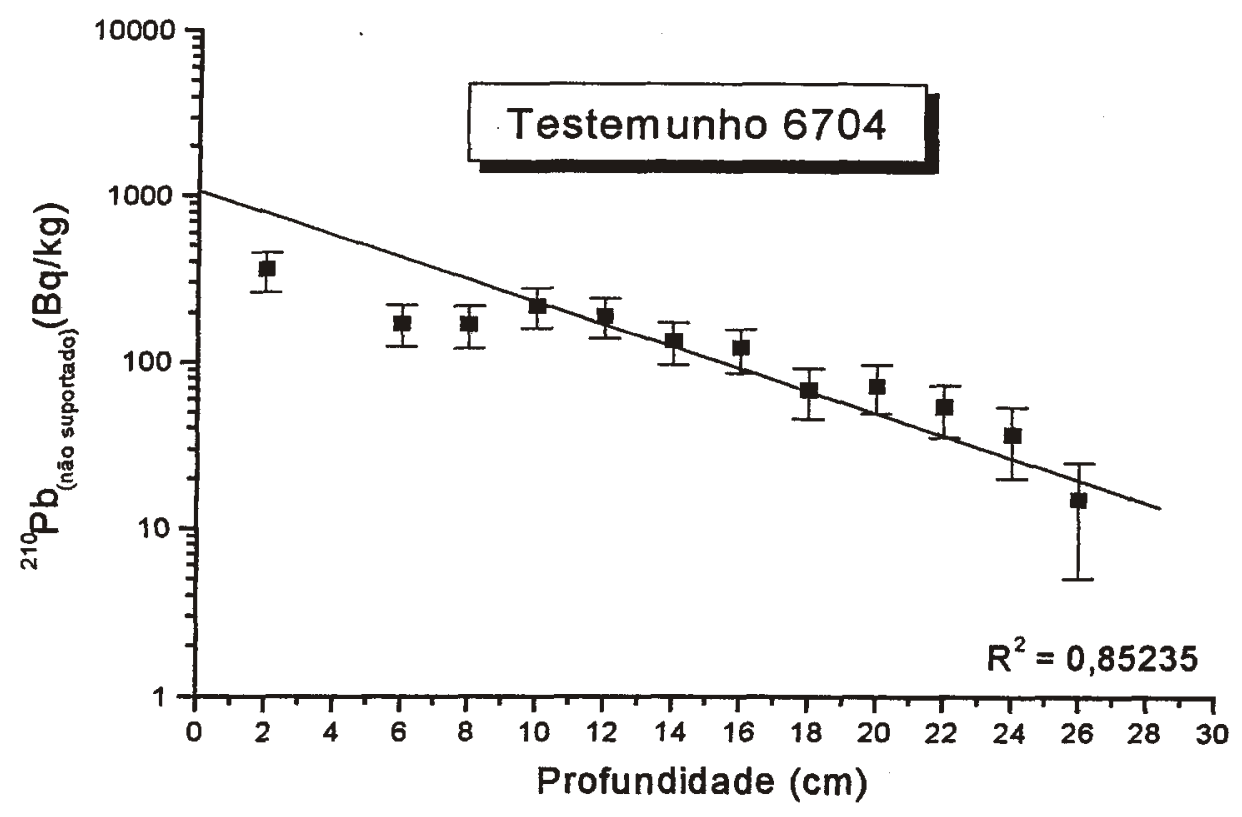

Figura 33: Gráfico ajustado da concentração de ${ }^{210} \mathrm{~Pb}_{\text {não suportado }}$ em função da profundidade para o testemunho 6700 . 


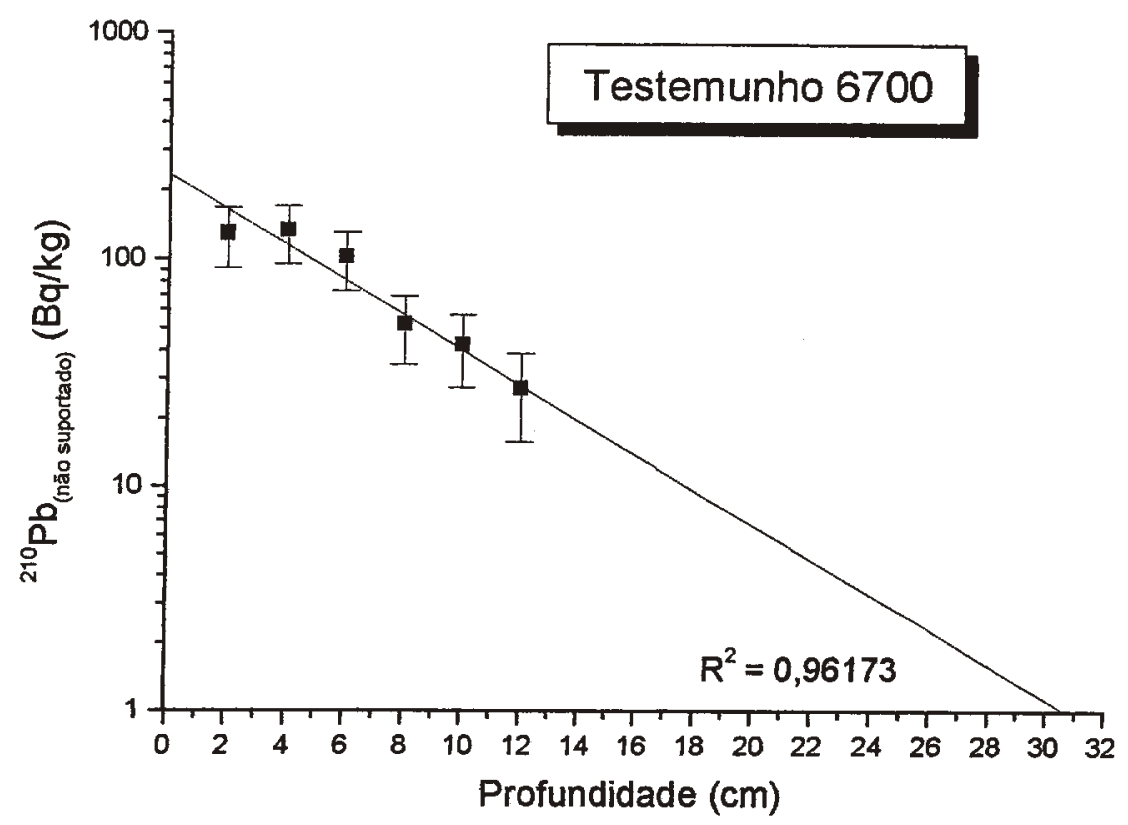

Figura 34: Gráfico ajustado da concentração de ${ }^{210} \mathrm{~Pb}_{\text {não suportado }}$ em função da profundidade para o testemunho 6704 . 